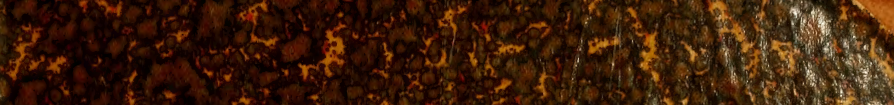

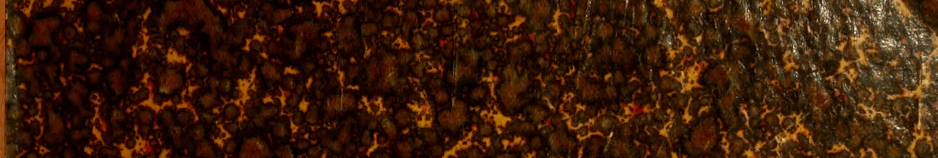

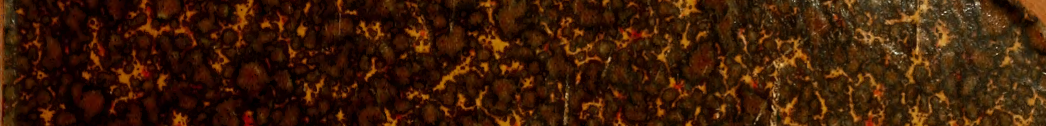

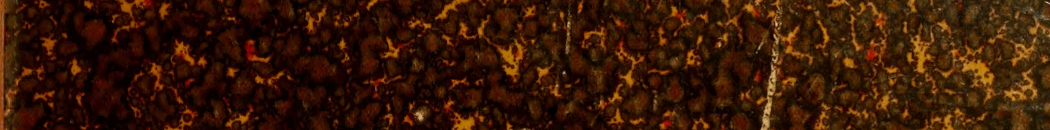
(1) 3.7. 2.

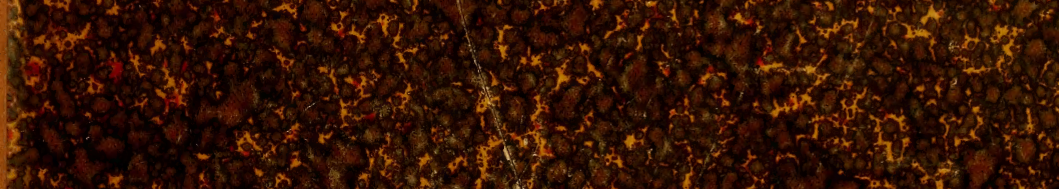

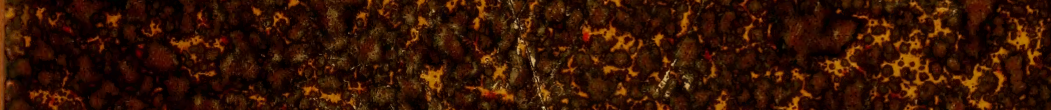
W. (1) 
A. AGASSIZ.

HARVARD UNIVERSITY.

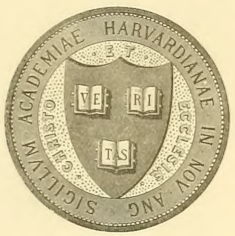

L I B R A R Y

OF THE

MUSEUM OF COMPARATIVE ZOÖLOGY.

GIFT OF

ALEX, AGASSIZ. 

attemorrs of the attuseum of Comparatioe \%oölogy

AT HARVARD COLLEGE.

VoL. XXXVIII. No. 1.

REPORTS ON THE SCIENTIFIC RESULTS OF THE EXPEDITION TO THE TROPICAL PACIFIC, IN CHARGE OF ALEXANDER AGASSIZ, ON THE U. S. FISH COMMISSION STEAMER "ALBATROSS," FROM AUGUST, 1899, TO MARCH, 1900, COMMANDER JEFFERSON F. MOSER, U. S. N., COMMANDING.

XII.

REPORTS ON THE SCIENTIFIC RESULTS OF THE EXPEDITION TO THE EASTERN TROPICAL PACIFIC, IN CHARGE OF ALEXANDER AGASSIZ, BY THE U. S, FISH COMMISSION STEAMER "ALBATROSS," FROM OCTOBER, 1904, TO MARCH, 1905, LIEUT. COMMANDER L. M. GARRETT, U. S. N., COMMANDING.

\title{
XVII.
}

\section{THE DEPTH AND MARINE DEPOSITS OF THE PACIFIC.}

\author{
Bx JOHN MURRAY AND G. V. LEE.
}

WITH FIVE PLATES AND THREE MAPS.

[Published by permission of George M. Bowers, U. S. Commissioner of Fish and Fisheries.]

CAMBRIDGE, U.S.A. :

租rinted for the flluseum.

JUNE, 1909. 


\section{TROPICAL PACIFIC.}

The following Publications of the Museum contain Reports on the Dredging Operations in charge of Alexander Agassiz, of the U. S. Fish Commission Steamer "Albatross," during 1899 and 1900, Commander Jefferson F. Moser, U.S. N., Commanding.

I. A. Agassiz. Preliminary Report and List of Stations. With Remarks on the Deep-Sea Deposits by Sir John Murray. Mem. M. C. Z., Vol. XXVI. No. 1. January, 1902. 114 pp. 21 Charts.

II. A. G. Mayer. Some Species of Partula from Tahiti. A Study in Variation. Mem. M. C. Z. Vol. XXVI. No. 2. January, 1902. 21 pp. 1 Plate.

III. A. Agassiz and A. G. Mayer. Medusæ. Mem. M. C. Z., Vol. XXVI. No. 3. January, 1902. 40 pp. 13 Plates, 1 Chart.

IV. A. Agassiz. The Coral Reefs of the Tropical Pacific. Mem. M. C. Z., Vol, XXVIII. February, 1903. 33, 410 pp. 238 Plates.

V. C. R. Eastman. Sharks' Teeth and Cetacean Bones from the Red Clay of the Tropical Pacific. Mem. M. C. Z., Vol. XXVI. No. 4. June, 1903. 14 pp. 3 Plates.

VI. W. E: Hoyle. Cephalopoda. Bull. M. C. Z., Vol. XLIII. No. 1. March, 1904. 71 pp. 12 Plates.

VII. H. Ludwig. Asteroidea. Mem. M. C. Z., Vol. XXXII. July, 1905. 12, 292 pp. 35 Plates, 1 Chart.

VIII. W. E. Ritter and Edith S. Brxbee. The Pelagic Tunicata. Mem. M. C. Z., Vol. XXVI. No. 5. August, 1905. 20 pp. 2 Plates.

IX. Mary J. Rathbun. The Brachyura. Mem. M. C. Z., Vol. XXXV. No. 2. August, 1907. 54 pp. 9 Plates.

X. C. H. Grlbert. The Lantern Fishes. Mem. M. C. Z., Vol, XXVI. No. 6. July, 1908. 23 pp. 6 Plates.

XI. A. Agassiz. Echini: The Genus Colobocentrotus. Mem. M. C. Z., Vol, XXXVI. No. 1. November, 1908. 8, 34 pp. 49 Plates.

XII. John Murrax and G. V. Lee. The Depth and Marine Deposits of the Pacific. Mem. M. C. Z., Vol. XXXVIII. No. 1. May, 1908. 172 pp. 5 Plates, 3 Maps. 
attemoirs of the atturseum of Comparatione \%oölogy

AT HARVARD COLLEGE.

Vol. XXXVIII. No. 1 .

REPORTS ON THE SCIENTIFIC RESULTS OF THE EXPEDITION TO THE TROPICAL PACIFIC, IN CHARGE OF ALEXANDER AGASSIZ, ON THE U. S. FISH COMMISSION STEAMER “ALBATROSS," FROM AUGUST, 1899, TO MARCH, 1900, COMMANDER JEFFERSON F. MOSER, U.S. N., COMMANDING.

\title{
XII.
}

REPORTS ON THE SCIENTIFIC RESULTS OF THE EXPEDITION TO THE EASTERN TROPICAL PACIFIC, IN CHARGE OF ALEXANDER AGASSIZ, BY THE U. S. FISH COMMISSION STEAMER "ALBATROSS," FROM OCTOBER, 1904, TO MARCH, 1905, LIEUT. COMMANDER L. M. GARRETT, U. S. N., COMMANDING.

XVII.

\section{THE DEPTH AND MARINE DEPOSITS OF THE PACIFIC.}

\author{
By JOHN MURRAY AND G. V. LEE.
}

WITH FIVE PLATES AND THREE MAPS.

[Published by permission of George M. Bowers, U. S. Commissioner of Fish and Fisheries.]

A CAMBRIDGE, U.S.A. :

看rinter for the ftuseum.

JunE, 1909. 
al

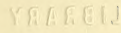

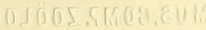

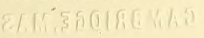




\section{CONTENTS.}

Introduction (Extracts from Dr. Alexander Agassiz's preliminary reports bearing on the bottom-deposits) . . . . . First Expedition . . . . .

Second Expedition . . . . . Third Expedition . . . . . . Fourth Expedition. . . . . . Воттом SAmples collected during the fourth expedition of Dr. Alexander Agassiz, 1904-1905 . . . Types of Deposits . . . . . . Pelagic Deposits . . . . . . Terrigenous Deposits. . . . . The Mineral Constituents observed in the different deposits . . . Methods used for determination Manganese Nodules . . . . . . Palagonitic Tuffs . . . . . . . Hardened Deposit . . . . . . . Phosphatic Coneretion . . . . . Sharks' Teeth and Cetacean Bones Detailed descriptions of the DepositSamples . . . . . . .

Воттом SAMpLEs collected during the third expedition of Dr. Alexander Agassiz, 1899-1900 . . .
Detailed Descriptions of the Deposit-

Samples . . . . . . . 81

Manganese Nodules . . . . . . 143

The Depths of the Pacific Ocean 149

Distribution of Marine Deposits

in the Pacific Ocean . . . . 153

I. Red Clay . . . . . . . 154

II. Globigerina Ooze . . . . . 154

III. Diatom Ooze . . . . . . . 155

IV. Radiolarian Ooze . . . . . 155

V. Pteropod Ooze . . . . . . 155

VI. Coral Mud and Sand . . . 156

VII. Other Terrigenous Deposits . 156

Percentage of Calcium CarboNATE in the Deposits covering the floor of the Pacific Ocean ........ 157

General Remarks and Conclusions ........ 160

Appendix. Notes on the examination of materials from Station 2 (1899-1900 cruise) and Station 4719 (1904-1905 cruise) by Dr.

W. A. Caspari. . . . . 165

A. Palagonitic Tuff . . . 165

B. Red Clay . . . . . . . 168

Explanation of the Plates. . . 171 



\section{THE DEPTH AND MARINE DEPOSITS OF THE PACIFIC OCEAN.}

\section{、 INTRODUCTION.}

OF all the additions to our knowledge of the depth and deposits of the Pacific Ocean during recent years, the most important are probably those acquired by Dr. Alexander Agassiz during his various cruises in the Pacific. Before proceeding to a detailed description of the samples of the deposits submitted to us for examination, it seems desirable to bring together the various accounts published in Dr. Alexander Agassiz's preliminary reports, as these show the observations made at the time of collection during the course of these expeditions.

First Expedition-Dr. Alexander Agassiz's first expedition in the Pacific, in the U. S. Fish Commission steamer "Albatross," in the year 1891, consisted of three short cruises off the west coast of Central America. The first cruise was from Panama to Point Mala, thence to Cocos Island, thence to Malpelo Island, and back to Panama. The second cruise was from Panama to Galera Point, thence to the southern face of the Galapagos, and thence to Acapulco. The third cruise was from Acapulco, up the Gulf of California, as far as Guaymas. Dr. Agassiz published a general sketch of the expedition, ${ }^{1}$ from which the following remarks on the character of the bottom-deposits are extracted:-

"We dredged frequently in most characteristic Globigerina ooze. On one occasion the trawl came up literally filled with masses of a species of Rhabdammina closely allied to R. lineata.

"It is interesting to note that, at two localities not far from the coast off Mariato Point, we came across patches of modern greensand similar in

1 Bull. Mus. Comp. Zoöl., Vol. XXIII., No. 1, 1892. 
formation to the patches discovered off the east coast of the United States by the earlier dredgings of the Coast Survey, of Pourtalès, and of the 'Blake.' . . .

"Nearly everywhere along our second line of exploration, except on the face of the Galapagos slope; we trawled upon a bottom either muddy or composed of Globigerina ooze, more or less contaminated with terrigenous deposits, and frequently covered with a great amount of decayed vegetable matter. We scarcely made a single haul of the trawl which did not bring up a considerable amount of decayed vegetable matter, and frequently logs, branches, twigs, seeds, leaves, fruits, much as during our first cruise.

"I was struck, while trawling on our second line between the Galapagos and Acapulco, to observe the great distance from shore to which true terrigenous deposits were carried. There was not a station there occupied of which the bottom could be characterized as strictly oceanic. At our most distant points from shore, the bottom specimens invariably showed some trace of admixture of terrigenous material. A very fine mud was the characteristic bottom we brought up, often very sticky, and enough of it usually remained in the trawl, even when coming up from depths of over 2,000 fathoms, materially to interfere with the assorting of the specimens contained in our hauls. This mud continued all the way from the Galapagos to Acapulco, and up to the mouth of the Gulf of California, where it became still more of an impediment to dredging, so that little work was done until we passed the Tres Marias. Even then the trawl was ordinarily well filled with mud, and with it came up the usual supply of logs, branches, twigs, and decayed vegetable matter.

"On going farther north, into the Gulf of California, the nature of the bottom did not change materially from what it had been along the coast from Acapulco to Cape Corrientes; it was the same viscid mud, mixed occasionally with Globigerinæ and masses of vegetable matter. So we found the trawling most difficult from the weight of the mud brought up, but occasionally a haul was made which more than repaid us for the time spent on the less productive ones.

"In the dredgings of the 'Blake' in the Gulf of Mexico, off the West Indies, and in the Caribbean, my attention had already been called to the immense amount of vegetable matter dredged up from a depth of over 1,500 fathoms on the lee side of the West India Islands. But in none of the dredgings we made on the Atlantic side of the Isthmus did we come 
upon such masses of decomposed vegetable matter as we found on this expedition. There was hardly a haul taken which did not supply a large quantity of water-logged wood, and more or less fresh twigs, leaves, seeds and fruits, in all possible stages of decomposition."

Second Expedition. - In 1897 Dr. Agassiz explored the coral reefs of the Fiji Islands, and published an interesting account ${ }^{1}$ of his results, but no bottom deposits were collected.

Third Expedition. - In 1899 and 1900 Dr. Agassiz made an extended cruise in the tropical Pacific, proceeding from San Francisco to the Marquesas, Paumotu, Society, Cook, Friendly, and Fiji groups of islands, thence through the Ellice, Gilbert, Marshall, Caroline, and Ladrone groups of islands to Japan. The following notes on the bottom-deposits are extracted from Dr. Agassiz's preliminary report ${ }^{2}$ on the scientific results of the expedition:-

"At Station 2, 2368 fathoms, lat. $28^{\circ} 23^{\prime}$ N., long. $126^{\circ} 57^{\prime}$ W., the trawl came up with the bag full of red clay and of manganese nodules, siliceous sponge spicules, a large pink Benthocetes, spines of Phormosoma, Euphronides, and Benthodytes in fragments. Together with the manganese nodules came up many sharks' teeth, whale ear-bones and other fragments of cetaceans more or less coated with manganese. There were a number of species of sharks represented: Carcharodon, Lamna, Oxyrhina, Carcharias. There were also a number of flat slabs coated with manganese, the majority from three to four inches thick, but many were nearly six inches through. We must have brought up at least 800 pounds' weight of nodules. The slabs seemed to, be composed of volcanic ash. There were many rounded masses of pumice covered by manganese and fragments of the stem of a Gorgonian (Isis) coated with manganese.

"At this station we obtained 116 sharks' teeth, a few ear-bones and other bones of whales and dolphins.

"NoтE. - Sir John Murray informs me that at Station 2 some of the material which seemed to be manganese nodules proved to be rocks, evidently of continental origin, covered with a thin coating of manganese.

"Mr. J. J. H. Teall, of the Geological Survey of England, who examined these rocks, reports that they are a fragment of a rounded, pebble, consisting of a typical hornblende andesite; a subangular fragment of a pale-green serpentine; an angular fragment of a fine-grained sandstone composed of grains of quartz, felspar, and epidote, minute grains of

\footnotetext{
1 Bull. Wus. Comp. Znöl., Vol. XXXIII., 1899.

2 Mem. Mus. Comp. Zoöl., Vol. XXVI., 1902, pp. 70-81.
} 


\section{0}

THE DEPTH AND MARINE DEPOSITS OF THE PACIFIC OCEAN.

mica being also present; fragments of a well-rounded pebble of black chert, traversed by microscopic quartz veins.

"How these pebbles, having all the characteristics of glacial-worn pebbles, came to be carried to this point is an interesting question. As the sharks' teeth and cetacean bones found in the red clay seem to indicate that since tertiary times there have been but very insignificant deposits at great distance from continental areas, similarly we may be tempted to assume that these pebbles, which could not have been transported to their present locality by any agency of the present epoch, were carried to it during the glacial epoch, the thin coating of manganese indicating how small have been the bottom deposits since the glacial period." . . .

"We could find no spherules of cosmic iron in the few samples of manganese nodules which we ground to powder. . . .

"At Station 13, in 2690 fathoms, lat. 9० 57' N., long. $137^{\circ} 47^{\prime} \mathrm{W}$., ... the 'Blake' trawl came up full of large manganese nodules, balls varying in diameter from $4 \frac{1}{2}$ to over 6 inches; a few of the largest measured $6 \frac{1}{4}$ inches in diameter. . . The manganese nodules were all more or less mammary; this is specially well-developed in the flat pieces. . . .

"At Station 31, in 2700 fathoms, lat. $12^{\circ} 20^{\prime}$ S., long. $144^{\circ} 15^{\prime} \mathrm{W}$. Red clay. The sea being a little too heavy for a successful haul, the 'Blake' trawl came up with the net badly torn; it must have had too heavy a load of manganese nodules, as the part of the bag left contained about a platefull of small, irregularly shaped nodules, incrusting also volcanic rock. . . .

"At Station 73 we lowered the trawl in 807 fathoms, lat. $17^{\circ} 27^{\prime} \mathrm{S}$, long. $149^{\circ} 32^{\prime} \mathrm{W}$. It brought up a mass of fine volcanic mud filled with sticks and leaves and decayed vegetation, fragments of rocks and other telluric material, pieces of sugar cane, and fragments of cocoanut shells. . . .

"At Station 133 we lowered the trawl in 742 fathoms, lat. $18^{\circ} 05^{\prime}$ S., long. $142^{\circ} 23^{\prime} \mathrm{W}$. . . . The trawl came up in pieces; the pocket of the bag contained a piece of obsidian as large as a hen's egg, a piece of pumice and of coral, both coated with manganese, a few fragments of wood similarly coated, a fragment of Tubipora, also coated, and a mass of Globigerinæ connected by manganese, as well as volcanic fragments and particles of manganese.

"At Station 134, in 807 fathoms, lat. $18^{\circ} 06^{\prime}$ S., long. $142^{\circ} 24^{\prime}$ W. . . . We sent the swabs down; brought up... some small manganese nodules and sharks' teeth. ...

"At Station 173, in 2440 fathoms, lat. $18^{\circ} 55^{\prime} \mathrm{S}$., long. $146^{\circ} 32^{\prime} \mathrm{W}$. . . The 'Blake' trawl brought up about half a ton of flattened manganese 
nodules, generally mammillated on the surface, and slabs of all sizes, from that of a large potato to that of a pea. Many of the nodules were spherical or ellipsoidal. Many of the flattened pieces contained large sharks' teeth; there were but few ear-bones or other bones of cetaceans. Some of the sharks' teeth were fully four inches long.

"At Station 183, in 2472 fathoms, lat. $19^{\circ} 04^{\prime}$ S., long. $167^{\circ} 41^{\prime}$ W. . . . The 'Blake' trawl came up with a large hole on the side and the bottom partly carried away, yet there were still left in the bag a number of small, flat manganese nodules, from the size of a small walnut down. The bag also contained a few pieces of pumice and one shark's tooth, a few siliceous sponge spicules, and fragments of a small siliceous sponge. . . .

"A comparison of the deposits collected by the 'Albatross' on the line from San Francisco to Tahiti with the 'Challenger' line of soundings from Station 253, north of the Hawaiian Islands to Tahiti, shows a great similarity in their characteristic structure. At Station 2 (lat. $28^{\circ} 23^{\prime}$ N., long. $126^{\circ}$ $51^{\prime}$ W.), in only 2368 fathoms, the 'Albatross' struck the characteristic Pacific red clay which was met with as far as Station 14 (lat. $6^{\circ} 41^{\prime} \mathrm{N}$, long. $137^{\circ}$ W.), where in 2776 fathoms Globigerinæ and Foraminifera predominated and no Radiolarians occurred, while at next station, in 2583 fathoms, Radiolarians were again obtained, as well as at Station 18 (lat. $6^{\circ} 25^{\prime}$ S., long. $138^{\circ} 59^{\prime}$ W.), in 2468 fathoms, and at Station 23 (lat. $8^{\circ} 33^{\prime} \mathrm{S}$., long. $139^{\circ} 36^{\prime}$ W.), in 1802 fathoms, near the Marquesas, together with volcanic particles. At the intermediate stations, varying in depth from 1939 to 2463 fathoms, Globigerina ooze was obtained. It may be stated that Stations 14 to 23 are in a general way in the tract of the equatorial current and counter current, characterized by the larger number of species constituting its surface fauna than in the stations to the north. . . .

"The bottom deposit at the stations in the vicinity of the Marquesas are characterized by an admixture of Globigerina ooze and volcanic particles. In the channel separating the Marquesas from the northwestern Paumotus, a distance of not more than four hundred and fifty miles, the deeper parts, in from 2456 fathoms to 2700 fathoms, are marked by all the characteristics of the deposits in the deeper parts of the eastern Pacific north of the Marquesas; the deposits passing from red clay associated with Radiolarians to red clay mixed with Foraminifera, and in the lesser depths, 1208 fathoms to 1932 fathoms, we meet with deposits consisting of Globigerina ooze, and finally coral sand in the vicinity of the Paumotu plateau. 
"Again in the channel separating the Paumotus from the Society Islands a deposit allied to red clay, composed in part of Globigerinæ, was found in the deeper parts at a depth of somewhat over 2200 fathoms; the Globigerinæ becoming mixed with large proportions of volcanic mud as we approached the Society Islands.

"Through the Paumotu Archipelago the soundings in less than 1400 fathoms are marked by the frequent occurrence of Pteropod ooze and of Globigerinæ, but by far the greater number of soundings show a bottom made up of Globigerinæ and of coral sand in proportion to the distance from the atolls; the coral sand being coarser nearer the shores, gradually becoming finer as we proceed seaward, and at the same time containing a larger percentage of Globigerinæ or of Pteropod shells. . . .

"A similar state of things is found to hold good with the deposits at the stations occupied in the central Paumotus, as well as in the easternmost islands of the Paumotus we visited. When the depths separating the islands are greater, . . . we find again red clay in depths varying from 2284 to 2467 fathoms containing a greater or less percentage of Foraminifera. Similarly . . . in the deep water which separates Anu Anuraro from Hereheretue, in 2265 and 2524 fathoms, the bottom deposit is red clay with an admixture of Foraminifera; while at stations varying in depth from about 700 fathoms to nearly 2000 fathoms the deposit is made up of coral sand, Pteropod ooze, and Globigerinse in different percentages, as in the deposits of the north-western Paumotus.

"The deep soundings between Hereheretue and Tahiti . . . were made up of red clay and Globigerinæ; and on approaching Tahiti the coral sand which characterized the vicinity of the atolls in the Paumotus is replaced in the Society Islands by volcanic mud and volcanic sand and a small percentage of Globigerinæ.

"One cannot fail to notice the frequent occurrence of particles of manganese and of small manganese nodules in the deposits through the Paumotus and Society Islands.

"In the deep water between Niue and Tonga which culminates at Station 186 (lat. $21^{\circ} 18^{\prime}$ S., long. $173^{\circ} 51^{\prime}$ W.) in 4540 fathoms, we meet with red clay deposits containing Radiolaria, . . . though at Station 182 the red clay in 2882 fathoms contained a considerable percentage of Globigerinæ.

"On the way from Vavau to Fiji we found volcanic mud to the westward 
of Letté while crossing the volcanic ridge which runs parallel to the Tonga Island plateau. Crossing the eastern Fiji plateau we meet with deposits of coarse coral sand, pteropod ooze, and fine coral ooze, associated with manganese particles and Globigerinæ, much as in the deposits of the Paumotus.

"On our way through the Ellice and Gilbert Islands to Jaluit we obtained in the proximity of the islands coarse coral sand, pteropod ooze, and fine coralsand ooze more or less mixed with Globigerinæ. In the deeper waters separating the islands of each group, and the groups themselves, we encountered only Globigerina ooze, varying greatly in the size of the species obtained; very coarse species being met with ... in the Gilbert group in 1365 and 1569 fathoms. ...

"In 2221 fathoms, between Apamama and Maiana, we met with the same Globigerinæ, characterizing the equatorial current, which we had obtained before in the Paumotus and to the northward. Although on our way to Jaluit from Taritari we sounded in over 2500 fathoms, yet we nowhere obtained red clay in the bottom deposit, either on that line or in the deep water separating the islands of the Ellice or of the Gilbert group. . . . We found the same conditions in the Marshall group, coarse coral-sand, passing, according to depth and distance from land, into fine coral-sand, or coral-sand ooze, with a gradually increasing percentage of Globigerinæ. These are met with in as great a depth as 2613 fathoms, between Jaluit and Ailanglab Lab and all through the Marshall group in deep water in the channels between the different groups. ...

"Red clay is, however, met with in the bottom deposits of the northern part of the Marshall group between Rongelab and Likieb ... in depths varying from 2469 to 2609 fathoms, though even at that depth it is associated with a considerable percentage of Globigerinz.

"Similarly on our way through the Carolines we found Globigerinæ to constitute a considerable percentage of the bottom deposits to depths of nearly 2500 fathoms. . . The bottom deposits in the Carolines consist, as we would naturally expect from the geological structure of the Carolines, near the island groups, in great part of volcanic mud mixed with coral sand and Globigerinæ; the size of the sand, volcanic or coral, gradually decreasing as the depth increases. . . .

“It is only as we pass into the 'Caroline Deep' separating the Carolines from Guam and the Ladrones that we come upon bottom deposits consisting of red clay, manganese nodules, and pumice, as well as volcanic particles; 
... and as we approach Guam, . . . in 2337 fathoms, we come upon deposits of fine volcanic sand.

"No soundings were made by the 'Albatross' on the line from Guam to Yokohama, as the line is parallel for a considerable length with that run by the 'Challenger' from the Admiralty Islands to Japan."

The same report also includes a few remarks by Sir John Murray on the bottom deposits, ${ }^{1}$ accompanied by two colored maps: one showing the distribution of the deposit types, and the other showing the depths, in the portion of the Pacific traversed by the "Albatross."

Fourth Expedition. - In the winter of 1904-1905 Dr. Alexander Agassiz made his most recent expedition in the "Albatross" in the eastern tropical Pacific. From San Francisco the "Albatross" proceeded to Panama, thence to the Galapagos Islands, and to Aguja Point in Peru, thence out into deep water and to Callao in Peru, thence to Sala y Gomez and Easter Island, then back to Galapagos Islands, thence to Manga Reva in the Paumotu Archipelago, and finally from Manga Reva to Acapulco. The following remarks on the bottom-deposits are extracted from Dr. Agassiz's General Report of the Expedition : ${ }^{2}$

"Off Mariato Point [on the voyage from San Francisco to Panama] the 'Albatross' made two hauls in the vicinity of the stations where in 1891 she found 'modern greensand' in 555 and 782 fathoms. It was interesting to find the greensand again, as the specimens collected in 1891 were lost in transit to Washington. ... On the $2 d$ [November] we left [Panama] for Mariato Point to make a few additional trawl hauls in the region of the greensand. In both the hauls made off Mariato Point greensand was found, but not in the quantity obtained in 1891. . .

" The bottom of the area explored by the 'Albatross' in 1891 is covered by green and brown mud mixed with masses of decayed and decaying vegetable matter. South of this area we come upon the great tracts of the Eastern Pacific, the bottom of which is covered by manganese nodules. The extent of this tract is shown in Plate 3, where are given the northern and eastern limits of the manganese nodules as well as its southern limit extending from Easter Island to Manga Reva. From the northern extremity of Moser Basin the line forming the northern limit of the manganese

1 Mem. Mus. Comp. Zoöl., Vol. XXVI., 1902, pp. 109-111, maps $1^{\mathrm{a}}$ and $1^{\mathrm{b}}$.

2 Ibid., Vol. XXXIII, 1906, pp. xi., xii., 5 et seq. 
THE DEPTH AND MARINE DEPOSITS OF THE PACIFIC OCEAN. 15

nodules runs in a southeasterly direction to about $100^{\circ} \mathrm{W}$. long., and $5^{\circ}$ south of the equator where it runs nearly due east off Aguja Point, its eastern line then runs south, parallel to the South American coast. The southern limit of the nodules as here given (Pl. 3 ) is probably not its southernmost limit, as the 'Challenger' obtained manganese nodules a long way south in the latitude of Valparaiso; but nothing is known of the character of the bottom on the area intervening between the lines of the 'Albatross' and 'Challenger.' The western and northern and eastern limits of the Radiolarian ooze (Pl. 3) indicate a great tract partly covering the area of manganese nodules.

"To the west of the Radiolarian ooze area lies a great tract of Globigerina ooze; it is east of the Marquesas and of the Paumotus and extends north some way into Moser Basin (Pl. 3).

"Diatoms are found in a very wide belt reaching from the equator to nearly the general latitude of $15^{\circ} \mathrm{S}$., in some localities south and west of Aguja Point, as well as others. Close to the South American coast they occur in sufficient quantities to have formed siliceous earth. It will be noted that the belt where diatoms occur is entirely within the influence of the western and northern set of the Humboldt current, and that while diatoms are found in great abundance in an area near the equator, yet they have undoubtedly been brought north by the Humboldt current from more southern latitudes than those explored by the 'Albatross,' and have been spread westward by the prevailing southeast trades of the belt where they are found (Pl. 4). . . .

"Hauls of the trawl made off the Galapagos and at the western extremity of our lines off Aguja Point brought us within the area of the manganese nodules, with its Radiolarian ooze mud, Cetacean ear-bones, and beaks of Cephalopods; nothing could stand the damaging work of these nodules in grinding to pieces all the animal life the trawl may have obtained (Pl. 3). Down to a depth of 2200 fathoms or so the bottom was constituted of Globigerina ooze, its character being more or less hidden when near the coast by the amount of detrital matter and terrigenous deposits which have drifted out to sea.

"North of the Galapagos, as in the 1891 expedition, we found vegetable matter at nearly all the stations, and between the Galapagos and Callao such material was not uncommon in the trawl.

"Beyond the line of 2200 fathoms dead radiolarians become quite abun- 
dant on the bottom, as well as in the mud of the manganese nodules, though among the nodules it was not uncommon to find an occasional Biloculina. Many of the dead radiolarians found on the bottom were obtained from the guts of Salpæ swimming near the surface or within the 300 -fathom line in the tow-nets sent to that depth. The same is the case with many of the Dinoflagellata which have been considered as deep-sea types. . . .

"The samples of the bottom obtained by the soundings taken by the expedition or gathered in the mud-bag and in the trawl indicate that an immense area of the bottom of the Eastern Pacific is covered with manganese nodules, and that they play an important part in determining the character of the bottom, not only in the area covered by this expedition but also in other oceanic regions; the Eastern Pacific area of manganese nodules probably extends to the northwest of our lines to join the stations where manganese nodules were found by the 'Albatross' in 1899 in the Moser Basin, on the line, San Francisco to Marquesas (Pl. 3).

"This area may also extend south of our lines, Callao to Easter Island, and join the line west of Valparaiso where the 'Challenger' obtained manganese nodules at many stations. I do not mean to imply that manganese nodules are present to the exclusion of radiolarians and of globigerinæ. It is probable that the layer of nodules is partly covered by them, and by the thick, sticky, dark chocolate-colored mud which is found wherever manganese nodules occur. ...

"The Salpæ guts gave us, in addition to the finer tow-nets, immense collections of radiolarians, diatoms, and dinoflagellata, many of which have been considered to live at great depth and upon the bottom. It is most interesting to note the number of diatoms found in this tropical region. They have usually been considered as characteristic of more temperate and colder regions. On several occasions the surface waters were greatly discolored by their presence, and the extent of their influence on the bottom deposits is shown by the discovery of a number of localities where the bottom samples at depths from 1490 to 2845 fathoms, in the track of the great Peruvian current, formed a true infusorial earth."

After these interesting extracts, giving details of the observations made on board ship during the various cruises, we may now proceed to a detailed description of the samples of these deposits which were sent to us for examination. 


\section{BOTTOM SAMPLES COLLECTED DURING THE FOURTH EX- PEDITION OF DR. ALEXANDER AGASSIZ, 1904-1905.}

The number of samples received was one hundred and six, but, unfortunately, a large proportion of these was not available for full description. Thus, in no less than twenty-nine cases, the labels could not be deciphered, most of them apparently terrigenous deposits. The labels indicating the position of each sample were not stuck on the bottles, but placed inside them, in contact with the deposit; curiously enough, in the case of the terrigenous deposits, the labels were, with a few exceptions, totally destroyed, while they were relatively well preserved in the samples of pelagic deposits. This is probably connected with the larger amount of decomposing organic matter in the terrigenous deposits.

In ten cases the material had evidently been subjected to a certain amount of washing, and could not therefore be looked upon as representing the deposit in situ, while in seven cases the material consisted of manganese nodules or rock fragments without any true deposit. In this way the number of samples fully described in the sequel is reduced to sixty. These are distributed in depth as follows:-

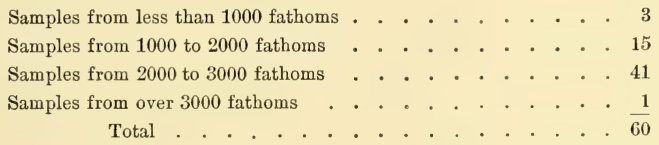

The types of deposit to which these sixty samples are referred are as follows :- -

\begin{tabular}{|c|c|c|c|c|c|c|c|c|c|c|c|c|c|c|}
\hline a Ooze & & & & & & & & & & & & & & \\
\hline d Clay. . & . & . . & . & . . & . & . & 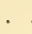 & & . & & & & & \\
\hline ud & . & & . & & & & & & . & & & & & \\
\hline . & . & . & . & & & & & & ${ }^{\circ}$ & & & & & \\
\hline us Mud & . & . . & . & & & & & & . & & & & & \\
\hline Volcanic Sand & . & . & 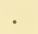 & & & & & & . & & & & & \\
\hline Diatom Ooze & . & . & & - & & & & & & & & & & \\
\hline
\end{tabular}

Between Panama and the Galapagos Islands the "Albatross" took samples of Green Sand and Green Mud in 556 and 776 fathoms respectively, off Mariato Point. About midway between Panama and the Galapagos 
Islands the deposit was Globigerina Ooze in 1705 fathoms, and again under the equator in 1418 fathoms, and close to Galapagos in 633 fathoms. On the voyage from the Galapagos Islands to Aguja Point, a deep sounding in 2235 fathoms gave a Red Clay, and nearer the coast, in 1036 fathoms, a Green Mud was taken. On the voyage from Aguja Point out into open water and thence to Callao, Red Clay was found in depths of 2370,2600 , 2845, 2338, and 3120 fathoms, and Blue Mud was found at 1490 and 1949 fathoms. On the voyage from Callao to Easter Island, the deposit was mostly Red Clay, except that at 2205 fathoms, in lat. $21^{\circ} 30^{\prime} \mathrm{S}$, long. $96^{\circ}$. W., a Globigerina Ooze was met with, but approximating to the Red Clay, since the percentage of calcium carbonate was only 34 . On approaching Sala y Gomez, Globigerina Ooze was again met with in 1939 fathoms, with Volcanic Sand close to Easter Island. After leaving Easter Island, the expedition apparently ran along the border-line between Red Clay and Globigerina Ooze, although the depths varied little; thus at 2020 fathoms, in lat. $25^{\circ} 22^{\prime} \mathrm{S}$, the percentage of calcium carbonate was 62 ; then in 2188 fathoms (lat. $23^{\circ} 24^{\prime}$ S.) the percentage fell to 11 , rising again to 33 at 2168 fathoms (lat. $21^{\circ} 39^{\prime} \mathrm{S}$.), falling again to 12 at 2265 fathoms (lat. $19^{\circ} 11^{\prime} \mathrm{S}$.), and rising again to 41 at 2228 fathoms (lat. $17^{\circ} 18^{\prime} \mathrm{S}$.), whence proceeding northwards the Globigerina Ooze became typical with a high percentage of calcium carbonate, and continued all the way until the Galapagos Islands were approached. On the passage from the Galapagos Islands to Manga Reva, the bottom was covered with Globigerina Ooze, except for a most unusual sample from 2285 fathoms (lat. $6^{\circ} 30^{\prime} \mathrm{S}$, long. $101^{\circ} 17^{\prime} \mathrm{W}$.), where a Red Clay containing no calcium carbonate was found. At the two stations on each side, the deposit was Globigerina Ooze, containing 60 per cent of calcium carbonate in 2153 fathoms, and 75 per cent of calcium carbonate in 2084 fathoms. One is almost inclined to conclude that this sample does not represent the deposit at the bottom, but that the shells of Foraminifera have in some way been removed, leaving only what we call "fine washings" in the bottle.

Immediately after leaving Manga Reva on the voyage to Acapulco, a sounding was taken in 2225 fathoms (lat. $21^{\circ} 4^{\prime} \mathrm{S}$., long. $133^{\circ} 1^{\prime} \mathrm{W}$.), where, according to Dr. Agassiz's preliminary report, the deposit was: "Red clay mud, many mineral particles, very few Globigerinæ, no Radiolaria or Diatoms." The material received is very peculiar, being mostly made up of amorphous calcium carbonate, and is quite unlike the deposit usually 
found at such a depth. At the next station in 2391 fathoms (lat. $18^{\circ} 29^{\prime} \mathrm{S}$., long. $130^{\circ} 51^{\prime}$ W.), the deposit was Red Clay containing 18 per cent of calcium carbonate; thence northwards the deposit continued to be Globigerina Ooze with a percentage of calcium carbonate exceeding 60 as far as lat. $5^{\circ} \mathrm{S}$., then, finally, a peculiar Red Clay was met with at 1955 fathoms (lat. $10^{\circ} 38^{\prime} \mathrm{N}$., long. $106^{\circ} 48^{\prime} \mathrm{W}$.), containing no calcium carbonate.

\section{Trpes of Deposits.}

The deposits obtained during this cruise of the U. S. S. "Albatross" all belong to "Deep-sea Deposits" found beyond the 100 -fathoms line. The ordinary classification still holds good in this case, and the material at hand gives typical examples of both terrigenous and pelagic deposits. As may be expected from the configuration of the eastern shores of the Pacific, the terrigenous deposits form only a narrow belt along the continental shelf of North and South America. We have there Blue Muds, Green Muds, and Green Sands, giving place to pelagic deposits as the depth increases towards the open sea.

Pelagic Deposits. Globigerina Ooze was the deposit most frequently met with, 36 samples having been studied. As regards the organisms that make up the calcium carbonate, it was at first proposed to give a complete list of the various species of Foraminifera, but as no difference could be found between the organisms of the successive stations, the Foraminifera are indicated merely as pelagic or bottom-living. The pelagic Foraminifera usually present are: Globigerina bulloides, Globigerina conglobata, Globigerina aquilateralis, Globigerina mubra, Globigerina dubia, Globigerina sacculifera, Orbulina universa, Spharoidina dehiscens, Pullenia obliquiloculata (very frequent), Pulvinulina menardii, and Pulvinulina tumida. Fishes' teeth and Echinoid spines are the most frequent calcareous remains that accompany the Foraminifera. ${ }^{1}$

Red Clay. The collection contains sixteen samples of Red Clay. The deepest sounding where this deposit was found was at 3120 fathoms, and the shallowest 1955 fathoms, the average depth being 2404 fathoms. The

1 The determination of the percentage of calcium carbonate was done throughont by means of the method based on the displacement of carbonic acid by an acid and loss of weight, a modification of Mohr's apparatus being used. This method is quite accurate and sensitive enough for the purpose, especially as calcium carbonate cannot be equally distributed throughout a sample, even when small, as is naturally the case with a deposit that has not been chemically, but mechanically, laid down, the size and abundance of the constituents varying continually, as may be expected from their organic origin. 
percentage of calcium carbonate varies from 0 to 20,0 per cent occurring nine times, and the mean being 5.33 per cent. The mean percentage of calcium carbonate in the Red Clays of the whole ocean is, according to the "Challenger" researches: 8.39 per cent in 18 samples from 2000 to 2500 fathoms, 7.16 per cent in 42 samples from 2500 to 3000 fathoms. The depths are of the same order of magnitude, and yet the percentage for the whole ocean is strikingly higher. The lower percentage in the case of the "Albatross" Red Clay may very possibly be connected with the distribution of the surface currents in this part of the ocean, and has certainly nothing to do with depth, as many of the samples of Globigerina Ooze were collected in depths not much less than those in which the Red Clay was found, the average depth for Globigerina Ooze being 2001 fathoms against 2404 fathoms for Red Clay, and in a few cases Red Clay was found in depths which at other stations allow Globigerina Ooze to be deposited. As an illustration we may mention the Red Clay of Station 4544 (lat. $10^{\circ} 38^{\prime} \mathrm{N}$., long. $106^{\circ} 47^{\prime} \mathrm{W}$.), where, although the depth is only 1955 fathoms, the amount of calcium carbonate is equal to 0 per cent.

Diatom Ooze is represented by a most interesting sample which will be found fully described later, and Radiolarian Ooze is represented by two unlabelled samples; Pteropod Ooze is not represented in the collection.

Terrigenous Deposits. Green Mud was found by the "Albatross" in two localities, in 776 and 1036 fathoms, and Green Sand in 556 fathoms. The calcium carbonate in one Green Mud was as high as 25 per cent; in the other only traces were found, while the percentage in the Green Sand was 5 . Glauconite is, of course, the characteristic mineral in these deposits, and is usually accompanied by a green flocculent matter, to which Sir John Murray and the late Professor Renard rightly attributed a vegetable origin. To test the question two samples from the Agulhas Bank were placed in small bottles and left to digest, the one in ether, the other in chloroform, and in both cases the solvent took a pronounced green tinge, a fact which strongly supports the above-mentioned view.

Blue Mud was found off Callao in 1490 and 1949 fathoms; in the former there was no calcium carbonate, while the latter contained 5 per cent.

Calcareous Mud. This name is applied here to a rather peculiar deposit met with in lat. $21^{\circ} 4^{\prime} \mathrm{S}$., long. $133^{\circ} 1^{\prime} \mathrm{W}$., in 2225 fathoms. The remarkable fact about this mud is that it is essentially composed of coccoliths and Tunicate spicules, together with a lirge quantity of calcium carbonate 
so finely comminuted as to appear quite amorphous under the microscope. Phillipsite in minute crystals is also present, and this is not the least interesting point in the deposit. As regards the origin of this mud there is no evidence at hand to show exactly what it is, but according to the preliminary report the sounding comes after a series of soundings which had revealed the presence of Coral Sand, in the vicinity of Manga Reva, in depths ranging from 225 to 1394 fathoms; this mud may thus possibly represent a very finely comminuted Coral Mud, the finer parts of which have been carried to the place where they were deposited, in a depth of 2225 fathoms. Reference to the description will show that the calcareous constituents of this deposit are so minute that there is no mechanical objection to the supposition that they may have been held in suspension in the water and carried away a certain distance from their point of origin. It must be observed, however, that there is no known coral reef within 150 miles of this position.

Volcanic Sand. A typical sample of this deposit was brought up from 1552 fathoms, off Easter Island.

\section{The Mineral Constituents Observed in the Different Deposits.}

The mineral constituents in the Globigerina Oozes found by the "Albatross" are, as a rule, very small. ${ }^{1}$ When estimating the percentage of minerals, the plan adopted by the authors of the Challenger Report on Deep-Sea Deposits was adhered to; that is to say, particles that are not washed away together with the fine clay are put down as "minerals." These were weighed, and the percentage estimated after deducting the amount of siliceous organisms as indicated later. In two cases no mineral particles were observed; in twenty-two cases the minerals were estimated as traces; in six cases the percentage is estimated at less than 1 , and in the remaining six the percentage varies from 1 to 5 . This fact is easily accounted for, as the ooze extends in a broad tract far from land, where the greater part of the mineral particles have a volcanic origin, continental débris being only accidentally met with.

Augite, plagioclase, volcanic glass, and magnetite are the minerals that usually accompany Globigerina Ooze in this part of the Pacific; the oxides of iron and manganese, in the shape of minute grains, are seldom absent, and, even when not present as grains, it is to them that the brown color of the "fine washings" is due.

\footnotetext{
1 Murray and Renard call particles exceeding $0.05 \mathrm{~mm}$. in diameter " minerals."
} 
A very interesting fact brought to light by the cruises of the "Albatross" and the "Nero" is that the presence of manganese nodules in a deposit is not at all incompatible with a high percentage of calcium carbonate, and especially if many volcanic minerals are at the same time present in the deposit, as indeed was indicated in the description of Station 297 in the Challenger Report on Deep-Sea Deposits. Nodules were found in one deposit containing 33 per cent of calcium carbonate, and in eight typical Globigerina Oozes containing respectively $77,62,78,54,60,75,50$, and 65 per cent of calcium carbonate. We have here a large proportion of the total number of stations where nodules were dredged, so that we may infer that manganese nodules are by no means exclusively characteristic of Red Clay. Their origin depends more on a ready supply of manganese and iron than on depth, and is not dependent on the presence or absence of calcareous organisms. ${ }^{1}$

The nodules, and specially those that are in course of formation, are often associated with palagonitic tuffs, on which the oxides form a coating of variable thickness; the oxides also form irregularly distributed nuclei within the cakes of palagonitic tuffs. We may mention here the peculiar formation of Station 4693 (lat. $26^{\circ} 30^{\prime}$ S., long. $105^{\circ} 45^{\prime} \mathrm{W}$.), where the oxides are deposited within, and on the surface of, consolidated cakes of Globigerina Ooze. This is the only instance met with during the cruise of a deposit being dredged as consolidated lumps. During the cruise of the "Challenger" a large piece of consolidated Globigerina rock was dredged between Arrou and Banda at a depth of 129 fathoms; this rock differs from the hardened ooze described here in being quite hard, requiring a sharp blow of the hammer to break it, and, moreover, it is not associated with manganese oxide. The formation most nearly resembling this one appears to be a Globigerina Ooze dredged by the S. S. "Britannia" in the year 1901 in lat. $14^{\circ} 32^{\prime} \mathrm{S}$. and long. $175^{\circ} 55^{\prime} \mathrm{W}$. According to the report by Sir John Murray and Mr. Peake, the material came up perfectly hard and dry, and required a hammer to knock it out of the tubes. Nevertheless, the phenomenon is of rare occurrence, and is worth mentioning.

Plillipsite is by no means rare in the Globigerina Ooze of this part of the Pacific Ocean. It was met with in five typical samples containing respec-

1 Reference to "A Contribution to the Oceanography of the Pacific," by James M. Flint (Bull. U.S.Nat. Mus., No. 55, 1905), will show that, in that part of the ocean traversed by the "Nero," manganese concretions are generally present, and sometimes quite numerous, in Globigerina Ooze. 
tively $40,65,58,72$, and 65 per cent of calcium carbonate, and also in one sample containing 33 per cent of calcium carbonate, which might be called a Red Clay. The samples were dredged in stations situated as follows:-

\begin{tabular}{|c|c|c|}
\hline Latitude. & Longitude. & Depth. \\
\hline $\begin{array}{rrr}17^{\circ} & 18^{\prime} & \mathrm{S} . \\
21^{\circ} & 36^{\prime} & \mathrm{S} . \\
22^{\circ} & 11^{\prime} & \mathrm{S} . \\
13^{\circ} & 51^{\prime} & \mathrm{S} . \\
9^{\circ} & 2^{\prime} & \mathrm{S} . \\
21^{\circ} & 39^{\prime} & \mathrm{S} .\end{array}$ & $\begin{array}{l}100^{\circ} 52^{\prime} \mathrm{W} . \\
131^{\circ} 35^{\prime} \mathrm{W} . \\
133^{\circ} 21^{\prime} \mathrm{W} . \\
126^{\circ} 53^{\prime} \mathrm{W} . \\
123^{\circ} 20^{\prime} \mathrm{W} \\
104^{\circ} 29^{\prime} \mathrm{W}\end{array}$ & $\begin{array}{l}2168 \text { fathoms. } \\
2228 \text { " } \\
2123 \text { " } \\
2042 \\
2186 \text { " } \\
2422\end{array}$ \\
\hline
\end{tabular}

These deposits have a truly pelagic character, having been formed far from land, so that the mineral elements contained in them have mostly a volcanic origin.

Reference to the descriptions will show the widespread distribution of such minerals as volcanic glass, palagonite, pumice, etc., while augite and felspars have almost certainly the same origin.

From the foregoing facts it will be seen that when a Globigerina Ooze forms far from land, its nature, when calcareous organisms are not taken into account, is very similar to that of a Red Clay, not only as regards its chemical composition, but also as regards secondary products formed in situ. It may be added that the minute calcareous coccoliths and rhabdoliths are nearly always represented, but never in large amount, so that they have not been indicated in the descriptions.

In Red Clay the minerals had to be put down as "traces" in the great majority of the descriptions; the highest percentage observed is one of 4 per cent at Station 4658, and even then the 4 per cent is nearly wholly represented by manganese grains. Actual mineral particles, volcanic or continental, never make up an appreciable amount as such, but, of course, if one could devise a means of separating and estimating the very minute particles that pass away in decantation together with the "fine washings," the relative percentages would be widely different. In the present study the mineral particles together with the siliceous organisms were always dried and weighed, and the relative proportions of siliceous organisms and minerals roughly estimated by counting the particles spread on a microscopic slide. When the weight of the residue was so small as to fall within the limits of experimental errors, minerals and siliceous organisms had to be estimated as traces. 
With the exception of three samples (from Stations 4649, 4666, 4672), collected very near the limit of the Blue Mud, the "Albatross" Red Clay shows all the typical characters of the deposit as regards its mineral constituents. The exceptions alluded to are clays in which quartz and glauconite were detected; on account of these minerals the deposit might perhaps in two eases have been called Blue Mud, but the total amount of minerals having been estimated as traces, it may also be called Red Clay, as it passes seawards into undoubted Red Clay, and there is no Globigerina Ooze marking the limit between these two deposits. The third sample partakes much more of the nature of Red Clay than of that of Blue Mud, as among the minerals manganese grains and volcanic glass are conspicuous (Station 4666).

Manganese nodules were present in six of the samples studied, and a greater number would, no doubt, be at hand, were it not for the fact that at many stations soundings alone were taken; trawling would almost certainly have shown the presence of nodules at all the stations, as manganese is always present in the form of grains. The nodules of Station 4658 (lat. $8^{\circ} 29^{\prime} \mathrm{S}$., long. $85^{\circ} 35^{\prime} \mathrm{W}$.), in 2370 fathoms, must rank among the finest ever dredged; they are of high specific gravity, very free from foreign admixture, their shape is remarkably constant, and most of them attain a very large size indeed.

The minerals that could be accurately determined, and that without any doubt as to their true nature, were not very numerous, the same species being generally represented in different stations with its usual characters.

Augite. Of clastic minerals the most frequently met with is a very pale brown, nearly colorless augite, generally in fragments, entire crystals being unusual.

Plagioclase. Next in order of abundance comes plagioclase, which, nearly every time it exhibits the necessary optical properties required for accurate determination, turns out to be a labradorite. For this determination use was made as much as possible of sections of definite orientation, preferably of those perpendicular to the acute or the obtuse bisectrix, and the results were calculated from the data given by Mr. Michel Lévy in his treatise on the determination of felspars. Very often, however, when the crystals were too small, as in the case of microlites, the determination had to be based on the measure of the value of the angle of extinction on lamellæ perpendicular to 
the plane (010), a determination quite reliable in the case of such highly basic felspars. Good results are also obtained by the use of liquids of known refractive index, as advocated by Schröder van der Kolk. The plagioclase is present as (1) microlites, (2) fragments of relatively large crystals, and (3) rarely in well-defined crystals with crystallographic outlines.

Orthoclase was not met with in the samples studied from this cruise, either through its being really absent from the mother-rocks, or through its having been quite decomposed. On the other hand it was found in a few deposits collected during the 1899-1900 cruise. It may not be out of place to draw attention once more to the fact that potassic felspars weather at a remarkably high rate under the action of sea-water.

Volcanic glass is one of the most typical constituents of the area surveyed by the "Albatross." It is quite colorless in certain cases, whilst distinctly brown and smoky in others. It is always present as sharp splinters of various sizes, from microscopic fragments to pieces quite visible to the naked eye.

Pumice. Large fragments of pumice were not often dredged during this cruise; on the other hand minute particles of finely comminuted pumice are of frequent occurrence, even at long distances from volcanic centres.

Palagonite is in certain cases extremely abundant, forming large cakes of palagonitic tuff. It forms angular grains of variable size (from $0.1 \mathrm{~mm}$. to 2 or $3 \mathrm{~mm}$.), yellowish or light brown in color, having a resinous lustre and conchoidal fracture. It is quite opaque unless in very thin sections, in which case it is slightly pellucid; it is also quite amorphous, exhibiting no trace of birefringence. As to its origin, it is, in the case of the material studied here, undoubtedly due to the decomposition of volcanic glass; in fact, certain specimens were observed showing the gradual transformation of the glass into palagonite. The latter is often accompanied by other products of decomposition, usually yellow or yellowish green, and exhibiting cryptocrystalline structure; decomposition is too far advanced to permit the determination of the original minerals.

Hornblende was only seldom met with.

Chlorite, the name being used in a broad acceptation, is fairly common, but it was found impossible to determine it specifically, owing to its cryptocrystalline structure and absence of well-defined optical properties. It is quite possible that this substance may be the product of the transformation of more than one kind of ferro-magnesian mineral. 
Olivine could be determined as such, with certainty, in a very few cases only, owing mainly to the microscopic size of the particles; it is, however, very likely more widely distributed than appears from the descriptions of the deposits, as it was often observed in the deposits of the 1899-1900 cruise.

Magnetite is a widely-distributed mineral constituent, being rarely absent.

Hematite is less frequently met with, though its occurrence is by no means rare.

Mica is relatively rare in these deep-sea deposits, and if present at all, is always much decomposed, becoming opaque, and losing its birefringence.

Very often mineral particles had to be put down as "products of decomposition," when nothing pointed to the exact nature of the original mineral.

Quartz. By far the greater part of the deposits studied belong to the pelagic class, so that quartz is rarely mentioned in the descriptions. Through a defect in the labelling of the bottles practically all the samples of Blue Muds, Green Muds, and Green Sands could not be localized, and had, therefore, to be left unstudied, a fact which brings down the degree of frequency of quartz. It will be noticed that for the same reason other continental minerals, such as tourmaline, zircon, and rutile, play no part in the descriptions, which would not have been the case had these deposits been studied.

Rock Fragments. The most frequent are fragments of rocks belonging to basic lavas, angite-andesites. These are black, with conchoidal fracture, and weather reddish-brown; all the fragments observed are angular.

From Station 4674, comparatively near the coast of Peru (lat. $12^{\circ} 14^{\prime}$ S., long. $78^{\circ} 43^{\prime} \mathrm{W}$.), some very large pieces of rock were dredged. They consist of angular pieces, some of them over a foot in length, of hard, compact, slightly argillaceous limestone, greenish-gray in color, containing in some places numerous examples of a Foraminifer belonging to the Textularidae, probably Bolivina.

At Station 4622 (lat. $6^{\circ} 21^{\prime}$ N., long. $81^{\circ} 44^{\prime}$ W.) a peculiar manganese nodule was dredged containing a nucleus made up of a white, hard, granular, silicified limestone, flat and angular, and doubtless of continental origin.

Secondary Minerals. Of minerals formed in situ the most frequently represented is glauconite, but as already stated, the deposits in which it is formed were badly labelled, and were not studied. We shall not add any more to the subject of glauconite, as part of the material on which our study 
of this mineral was based ${ }^{1}$ came from the eastern shores of the Pacific in the neighborhood of the track of the "Albatross."

The oxides of iron and manganese are widely distributed in the pelagic deposits, either as grains or as nodules. There is hardly a Red Clay or a Globigerina Ooze that does not contain manganese grains, or, at least, minute particles diffused in the "fine washings." The grains average $0.1 \mathrm{~mm}$. in diameter, and have generally a botryoidal shape and shining surface; the minute particles found in the "fine washings" have no sharply defined outlines, and appear to be mixed with more or less clayey matter, giving them a floceulent appearance.

Phillipsite is of frequent occurrence and has been observed in Globigerina Ooze as well as in Red Clay, but not in such large amount as is the case with some of the Red Clays dredged further south by the "Challenger." Isolated crystals are much more frequent than clusters; their breadth is relatively larger than in the case of those found by the "Challenger," the proportion of breadth to length being generally from 1 to 3 to 1 to 4 . As it often happened that only little material was available, it is quite possible that phillipsite may have escaped observation more than once, and, therefore, may be more abundantly distributed than it appears to be from the descriptions.

Methods used for Determination. Examination in reflected light with the binocular microscope was always made of the mineral particles as they stood after removal of the carbonate of calcium and the washing away of the finer material. This examination gives indications as to the weathering of the minerals, and as to their mutual relations, that is, a particle of magnetite, for instance, may be quite free, or, on the other hand, firmly attached to some other mineral.

After this preliminary examination the particles are measured with a graduated ocular micrometer, and then, if sufficiently thin, directly examined under the mineralogical microscope. For all purposes one can dispense with actual slides mounted in balsam; if the particles are too thick, they are ground in an agate mortar to the requisite thinness; the diameter will, of course, correspondingly decrease, but with a high power and an ocular furnished with an iris diaphragm, the figures of interference in convergent light can still easily be observed. This method saves much of the time that would be required in order to make thin slices, and allows the studying of different 1906 .

1 See Collet et Lee, "Recherches sur la Glauconie." Proc. Roy. Soc. Edin., Vol. XXVI., p. 238, 
portions of the same sounding to be rapidly made; after the washings have been dried, the Schröder van der Kolk method is serviceable for determination by means of the refractive index.

In the case of particles belonging to the "fine washings," often much less than $0.01 \mathrm{~mm}$. in thickness, a systematic microscopical examination cannot be made, optical properties becoming indistinct in the case of all the minerals excepting those that are highly birefringent. They can, however, often be empirically determined, a little practice showing by comparison what is the usual habit of one particular mineral. For instance, phillipsite is not to be mistaken, even when in extremely minute crystals, its shape and general appearance being characteristic.

One has also sometimes to have recourse to chemical analysis in order to ascertain the nature of certain opaque, shapeless minerals, such as the oxides of iron and manganese, phosphatic concretions, etc.

\section{Manganese Nodules.}

We give here descriptions of the manganese nodules obtained at the various stations, arranged in the order of the cruise.

Station 4622, 21st October, 1904. Lat. $6^{\circ} 21^{\prime}$ N.; long. $81^{\circ} 44^{\prime} \mathrm{W}$.; depth, 581 fathoms.

Fragments of a large and curiously shaped nodule were obtained at this station. A flat piece of rock, four inches long by one-half inch thick, served as a nucleus, having a thick covering of manganese and iron oxides. The rock is some altered limestone, in which the greater part of the calcium carbonate has been replaced by silica. The coating varies in thickness, being in places as much as an inch, and shows a distinct arrangement in layers, some layers being richer in iron than others. The nodule is too fragmentary to enable one to restore its original shape, but it may be assumed that it was very likely oblong, following generally the outline of the rock forming the core. There is nothing to show what is the nature of the deposit in which the nodule was found.

Station 4656,13 th November, 1904 . Lat. $6^{\circ} 54.6^{\prime}$ S., long. $83^{\circ} 34.3^{\prime} \mathrm{W}$.; depth, 2222 fathoms.

No deposit was received from this station, but there were a good many nodules, and from the traces of deposit adhering to them it may be inferred that the nodules were formed in a Red Clay; the station is, moreover, near 
two other stations where the deposit is a Red Clay. The nodules are of low specific gravity, with no shining lustre, and are rather incoherent, being always mixed with a large proportion of foreign elements.

The first stage towards the formation of nodules is represented by cakes of palagonite and other decomposed minerals (chloritic minerals and decomposed felspar, besides palagonite formed by decomposed glass), in which the mineral particles are coated with a thin layer of the oxides; the whole cake may also be coated with the oxides. The more perfect nodules are not formed of solid oxides, but round a core of palagonite comes a layer of oxides, then another layer of palagonite, and the latter is again covered with oxides, and so on.

The most interesting point about this station is that it contains remarkable examples of deposition of manganese-iron oxides round very different centres of accretion: we have here some curiously shaped pseudo-nodules which are undoubtedly silicus sponges impregnated with manganese and iron oxides. The entire sponge is not always wholly preserved, but the siliceous skeleton can always be detected, unaltered, in the midst of the oxides in which it is embedded.

Organisms, sometimes of large size (Hydroids), are specially abundant, and can be seen attached in their original position on the surface of nearly all the specimens. They are often distributed on the whole of the surface of the nodule, so that the latter was either not deeply buried in the mud, or had its position shifted.

The lack of metallic lustre alluded to is very likely due to the large proportion of palagonite and other products of decomposition, taking part in the formation of the nodules.

It may be added that it was possible to observe on certain grains of palagonite the gradual transformation of brown volcanic glass into that mineral, but such instances are of rare occurrence. It was also found, in studying this material, that certain crystalline minerals, possibly felspar, form products of decomposition very similar to that of volcanic glass.

Station 4658, 14th November, 1904. Lat. $8^{\circ} 29.5^{\prime}$ S. ; long. $85^{\circ} 35.6^{\prime} \mathrm{W}$.; depth, 2370 fathoms.

The nodules from this station (see Pl. 1, figs. 1, 2) are as remarkable for their large size as for their constant shape, which is on a definite pattern. These nodules have each two surfaces, which are, roughly speaking, re- 
spectively dome-shaped and cone-shaped. Looking normally at one of the surfaces, the wider portion is circular, so that there is practically an axis of symmetry passing through the apex of both surfaces. The dome-shaped one is due to the aggregation of a few smoothly undulating bosses or protuberances of large radius. It is very smooth and black, with a metallic lustre, and has a distinctly scaly structure. The other surface is mammillated, has a dull color, and is incoherent, breaking up with little exertion of the fingers. A certain amount of clay is, moreover, mixed with the oxides, filling the cavities between the mammillæ. The important point is that living organisms are implanted on that surface, arenaceous Foraminifera and Polyzoa, all of them in their natural state, and not containing the oxides of manganese and iron. In one case the apex is formed by a well-preserved ear-bone, also quite free from these oxides. ${ }^{1}$

A section across a nodule shows it to be formed of successive concentric layers following exactly in their distribution the contours of the smooth surface. The innermost layer has absolutely the same shape as the outer one. The difference between the alternate layers is mainly one of hardness. In the samples cut, it has not been possible to find what was originally the centre of accretion; it probably consisted of some material which has since been transformed, or rather, replaced, by the oxides.

This particular kind of nodule does not appear to have been described before; the nearest approach to it, as regards shape, is one represented in fig. 4, Plate 3, of the Challenger Report on Deep-Sea Deposits.

Station 4660,15 th November, 1904 . Lat. $9^{\circ} 55.6^{\prime}$ S.; long. $87^{\circ} 30^{\prime} \mathrm{W}$.; depth, 2425 fathoms.

No deposit is at hand from this station, but three large manganese nodules were received, on the surfaces of which some of the deposit, a Red Clay, is still adhering. These nodules have a massive, irregular shape, and the largest one is no less than seven inches in diameter. They are characterized by a kind of non-homogeneity, i.e. they are not formed of one solid lump of manganese-iron oxides, but rather of numerous smaller nodules grafted the one on the other. There is no metallic lustre, but

${ }^{1}$ Dr. Lee holds that the logical conclusion is that the cone-shaped mammillated surface is the upper surface, the smooth shining one being embedded in the clay, whereas Sir John Murray takes the riew from his "Challenger" experience that the smooth surface was the upper one, and points to figure 1, Plate IX, of the Challenger Report on Deep-Sea Deposits as confirmation of this, the smooth surface in his opinion being formed above the level of the deposit. 
under the pressure of a hard smooth body, such as an agate pestle, they take on a very shining metallic lustre. The nature of the surface does not vary, so that the part embedded in the clay does not differ from the uppermost one.

The smallest nodule (four inches in diameter) exhibits well the non-homogeneous character alluded to ; it is formed of a flat slab, one inch thick, on which is grafted another nodule, hemispherical in shape, the surface of separation being marked by a thin layer of clay. The slab is broken, and the fracture shows that no nucleus is present, or, if one has been present, it has been replaced by the oxides.

After treatment with hydrochloric acid there remains but very little residue, which is very light and formed of palagonite and other decomposed minerals, and of pumice very much altered.

Station 4662,16 th November, $1904 . \quad$ Lat. $11^{\circ} 13.8^{\prime}$ S. ; long. $89^{\circ} 35^{\prime} \mathrm{W}$.; depth, 2439 fathoms.

No deposit is at hand from this station, but many manganese nodules were received (see Pl. 2, fig. 3). There is much difference between the various nodules; they do not appear to have been built on a constant pattern, and have not the general family likeness that one sees, as a rule, in nodules collected in one station. According to their nature and appearance, they may be divided into three groups: (1) imperfect nodules - cakes of palagonite and volcanic ash, more or less impregnated with oxides and covered with a coating of the latter; (2) perfect nodules - very similar to those of Station 4658, that is, having a circular section and two surfaces, the one dome-shaped, the other practically level; the dome-shaped surface has no mammillæ or protuberances, but has the appearance of shagreen, whilst the other surface is furnished with mammillæ which have a metallic lustre; (3) the third category is represented by nodules similar to those of Station 4660 ; they have a massive, irregular shape, and look more like clusters of smaller nodules than like one solid lump of the oxides. One of them shows the presence of a good deal of fine-grained, decomposed volcanic ash, forming a kind of nucleus, round which the oxides are deposited, more thickly in some parts than in others, so as to form pronounced mammillæ.

Even the more perfect of these nodules (No. 2) can often be broken in the hands by the exertion of a little strength, and the fracture always appears to take place along cracks which had existed for a long time when 
the nodule was at the bottom of the sea, as both sides are coated with a thin film of clay.

Station 4676, 5th December, 1904 . Lat. $14^{\circ} 28.9^{\prime}$ S. ; long. $81^{\circ} 24^{\prime}$ W.; depth, 2714 fathoms.

About half a dozen manganese nodules were brought up at this station, the largest being two and one-half inches in diameter. Their shape is somewhat spherical, but with a very rough surface, the mammillæ being very sharppointed and acute. On the surface remnants of living organisms, such as siliceous Sponges, are to be seen. The nodules are far from being formed exclusively of the oxides of iron and manganese; the general appearance of a section made across a nodule shows it to be also partly made up of the clay itself, with a good many small mineral particles. Many of the latter are decomposed and cannot be determined, but felspar, volcanic glass, and probably augite, can still be recognized.

A section made across a nodule did not reveal the presence of any hard nucleus, and there is no trace of concentric structure, the nature of the concretion being the same throughout, excepting towards the periphery, where the clayey element is more conspicuous. A powdered portion of nodule, treated with hydrochloric acid, leaves a residue quite similar to the clay itself, with the only difference that mineral particles are there a little more numerous, though very small, averaging $0.005 \mathrm{~mm}$. in diameter, only a few being as much as $0.02 \mathrm{~mm}$. Of these, augite and felspar are the only particles recognizable.

Station 4681, 8th December, 1904. Lat. $18^{\circ} 47.1^{\prime}$ S. ; long. $89^{\circ} 26^{\prime}$ W. ; depth, 2395 fathoms.

The nodules from this station vary in shape, from slabs two and one-half inches in diameter to flat, elliptical, bean-shaped nodules. The more strictly nodular forms (one inch in diameter) have a rather large nuclens, composed of palagonite mixed with clay proper; concentric structure is hardly noticeable, affecting only the outer zone. Both surfaces are structurally identical, though the one is generally more soiled with clay than the other. In both cases the surface is not shining, but finely granulated.

The slabs have the same structure; the internal layer contains more mineral particles than the outer ones. Both surfaces are also finely granulated, but one is nearly flat, whilst the other is mammillated. On the flat 
THE DEPTH AND MARINE DEPOSITS OF THE PACIFIC OCEAN. 33

side there are worm-tracks and arenaceous Foraminifera, together with some egg-like white capsules. The flat side is, therefore, in this case the upper one.

Station 4685, 10th December, 1904. Lat. $21^{\circ} 36.2^{\prime} \mathrm{S}$.; long. $94^{\circ} 56^{\prime} \mathrm{W}$.; depth, 2205 fathoms.

Numerous pieces of manganese slabs and a few manganese nodules were brought up at this station. The slabs, which may be as much as six inches in length and one and one-fourth inches in thickness, are essentially cakes of volcanic ash more or less impregnated with the oxides of manganese and iron, with formation of an actual crust of the oxides on both surfaces. The volcanic ash is made up of particles of augite, some of which belong to the violet variety, of basic felspar, and of volcanic glass, more or less decomposed. The particles have a diameter of 0.01 to $0.02 \mathrm{~mm}$., and are often even smaller.

The nodules are not so abundant as the slabs. They are discoidal, their shape recalling that of a broad bean, and their diameter is from onehalf of an inch to three-fourths of an inch. They sometimes occur in clusters of two or three individuals. The structure is scaly, due to the concentric arrangement of the layers; the centre of the nodule is occupied by a nucleus formed of an aggregate of loose mineral particles, attaining a diameter of $0.08 \mathrm{~mm}$., which are the same as those occurring in the slabs, $i$. e. a great quantity of augite, with volcanic glass and plagioclase. Magnetite is also present. There is no marked transition between the nucleus and the body of the nodule proper, so that it is difficult to say what is the relative proportion of the diameter of the nucleus to that of the nodule; yet it appears to be not more than about one-fifth in the case of a typical nodule.

Station 4711, 31st December, 1904. Lat. $7^{\circ} 47.5^{\prime} \mathrm{S}$.; long. $94^{\circ} 5.5^{\prime} \mathrm{W}$.; depth, 2240 fathoms.

The Globigerina Ooze from this station contains numerous typical manganese nodules (see Pl. 2, fig. 4), some of which rival those from Station 4658. About half a dozen are of very large size, one measuring six inches in diameter. As they all have a distinctly mammillated structure, the mammillæ breaking off easily, many of the smaller nodules must be considered as having formed part of the larger ones. 
As regards shape, the nodules do not appear to have been built according to a definite type. They are angular, and have roughly the same diameter in all directions. They are all mammillated, the mammillæ being very prominent, each standing apart. A section across a nodule shows it to be compact and homogeneous, in spite of a distinct concentric arrangement, the different layers being in close contact with each other, and there is no softer material between each consecutive layer. The transverse section of the various layers does not form a regular line, but is sinuous, each layer espousing the contour of the preceding, till one approaches the root of the external mammillæ, where there is no relation between the last layer and the mammillæ surmounting it. It appears as if on some smooth nodule, with only faintly outlined mammillæ, a new generation of mammillæ had been grafted, independently of the original protuberances.

Many nodules exhibit, though to no very great extent, an upper and an under surface; that is to say, in one case the mammillæ are larger and smoother than in the other, where they are rougher and more distinctly separated from each other. This could perhaps have been seen on all the nodules, if during the process of collecting the mammillæ had not been often destroyed.

Though a section across a nodule shows a concentric arrangement, still no material playing the part of a nucleus can be seen. They are also very free from foreign admixtures; in the parts less rich in oxides the microscope shows only the presence of some kind of chloritic mineral, with augite and microlites of felspar. Palagonite, so often met with in similar formations, appears to be absent. Magnetic particles are likewise absent.

Station 4717, 13th January, 1905. Lat. $5^{\circ} 10^{\prime}$ S.; long. $98^{\circ} 56^{\prime} \mathrm{W}$.; depth, 2153 fathoms.

A few small manganese nodules accompanied the Globigerina Ooze from this station. They are flat in shape, and the diameter of the largest one does not exceed three-fourths of an inch, its thickness being about one-fourth of an inch. Both surfaces are identical, with a granulated appearance. Internally there is no concentric arrangement, the external granular portion alone forming a differentiated layer.

These nodules are coal-black, quite hard, and must be considered perfect nodules, although the deposit is a typical Globigerina Ooze. 
THE DEPTH AND MARINE DEPOSITS OF THE PACIFIC OCEAN. 35

Station 4721, 15th January, 1905 . Lat. $8^{\circ} 7.5^{\prime}$ S. ; long. $104^{\circ} 10.5^{\prime}$ W.; depth, 2084 fathoms.

The trawl brought up a fair quantity of manganese nodules, although the deposit is a Globigerina Ooze with 75 per cent of calcium carbonate. These nodules have a peculiar appearance, being generally of low specific gravity, somewhat slaggy looking, with a dull, not shining surface. They have a very irregular shape, mostly flattened, and the diameter of the largest does not exceed three inches. As regards structure, there is no concentric arrangement round a central nucleus, the substance being equally distributed throughout. They are not formed of pure iron and manganese oxides, but contain a large amount of palagonite, in grains averaging $1 \mathrm{~mm}$. in diameter; the grains are visible in the nodules themselves, but can be best seen after removing the oxides with hydrochloric acid. Fresh, undecomposed minerals are very few. The oxides very often form a coating round each grain of palagonite, the whole nodule having then a granular structure.

Besides actual nodules there are also deposits of manganese-iron oxides round what were originally siliceous Sponges, and in two cases the shape is well preserved; the siliceous skeleton has not disappeared, and can still be seen on fractures, with a magnifying glass (see Pl. 3, fig. 5).

Generally speaking, one may say that at this station manganese and iron oxides impregnated either Sponges or fragments of palagonite, these being possibly the only solid bodies present. But in no case is concentric arrangement round one central nucleus to be seen.

Station 4740, 11th February, 1905. Lat. $9^{\circ} 2.1^{\prime}$ S., long. $123^{\circ} 20.1^{\prime} \mathrm{W}$.; depth, 2422 fathoms.

Three small manganese nodules were brought up at this station. These call for no special description, but it is interesting to note their presence in a typical Globigerina Ooze.

\section{Palagonitic Tuffs.}

In addition to the cakes of volcanic ash described under Station 4685 , palagonitic tuffs were brought up at two other stations:-

Station 4736 , 23rd January, 1905. Lat. $19^{\circ} 0.4^{\prime}$ S.; long. $125^{\circ} 5.4^{\prime}$ W.; depth, 2289 fathoms.

Several large cakes of palagonitic tuff from this station were mixed with 
varied amounts of manganese grains and a few undeterminable crystalline particles, and coated with a thin film of manganese. Palagonite largely predominates over manganese, and has all its usual characters: yellow color, low specific gravity, and hardness. Besides palagonite proper there are also angular yellow grains, which exhibit crypto-crystalline structure, but it is not possible to say what is the mineral they are derived from. One of the slabs is eight inches in length, four inches in breadth, and one and onehalf inches in thickness, and is in the same state as it was in at the bottom of the sea, as the coating of oxides extends all over it. One side is still covered with mud, whilst the other is free from it. Both surfaces are very uneven, being full of hollows and protuberances, which resemble wormtracks in many instances. No organisms have been observed on either surface of the slabs.

Referring to the description of the Globigerina Ooze from which the slabs were dredged, it will be remarked that curiously enough the minerals had to be estimated as traces; the only deduction that can be made is that the volcanic material which formed the slabs was deposited during a phase of volcanic activity which had nearly ceased when the ooze itself was laid down.

Disturbances of the sea-bottom might be indicated by the regular shape of some of the slabs, which are coated with manganese on their whole surface, after having probably been broken off some much larger flags, as their shape indicates, and that very likely through volcanic action or movement of the earth's crust. There is mention of a similar phenomenon in the Challenger Report on Deep-Sea Deposits, p. 124, Station 281, Oct. 6, 1875.

Station 4695, 23rd December, 1904. Lat. 2522.4' S.; long. $107^{\circ} 45^{\prime} \mathrm{W}$; depth, 2020 fathoms.

By far the greater part of the solid material brought up at this station is represented by large, irregular fragments of palagonitic tuff, up to five inches in length, and coated with oxides of manganese and iron. The external surfaces have a distinctly mammillated structure, more pronounced on one side than on the other; worm-tubes may be seen on both surfaces.

The tuff has a very low specific gravity, and is easily crushed between the fingers. It is formed of yellow palagonite, with a waxy lustre, in fragments from a fraction of a millimeter up to five or more millimeters in diameter, cemented by a brown amorphous matter, which represents, most likely, a further product of the decomposition of the palagonite. 
The tuff does not contain any organisms, either calcareous or siliceous; in all the specimens manganese oxide grains are irregularly distributed throughout the mass, and some specimens contain large patches of the oxides.

From this same station the trawl also brought up pieces of pumice, one to two inches in diameter; a flat piece of black volcanic glass, very much decomposed, but still recognizable, coated with a continuous layer of the oxides of manganese and iron, the decomposition proceeding apparently along cracks, so that with a little effort the fragment can be broken between the fingers; rounded pieces of decomposed rock, of high specific gravity, are also coated with the oxides, the rock itself having turned yellowish-brown through decomposition.

\section{Hardened Deposit.}

From Station 4693 (lat. $26^{\circ} 30.1^{\prime}$ S. ; long. $105^{\circ} 45.2^{\prime}$ W.; depth, 1142 fathoms ; 14th December, 1904), angular blocks of consolidated Globigerina Ooze, more or less covered and impregnated with manganese and iron oxides, were brought up. These blocks (see Pl. 3, fig. 6) vary in size from a fraction of an inch to four inches in diameter. In general appearance they look very much like slag, the outer surface being rough, vesicular, and mammillated. Of the specimens, the poorest in manganese oxide is a nearly pure white agglomerate of Foraminifera with irregularly distributed patches of the oxides inside the fragment, whilst the outside has the slaggy surface alluded to. Its specific gravity is low. Another sample, also chiefly composed of Foraminifera, is more coherent, and has a higher specific gravity. In more advanced stages the proportion of the oxides increases and is more equally distributed throughout the mass, giving it a rusty brown tinge, while the density increases. Other samples show a similar further increase in the proportion of the oxides of iron and manganese, but in none is a complete replacement of the carbonate of calcium by the oxides to be seen; even the parts purest in manganese still give a marked effervescence with acid.

As regards structure, there is no tendency towards an arrangement in concentric layers around a common nucleus. The very few mineral particles present in these concretions are very small, and belong to the chlorite group and other products of the decomposition of ferruginous minerals.

Though the above concretions are not actual manganese nodules, they mark at least one step towards the formation of nodules, and this under 
rather exceptional circumstances, the deposit itself being a Globigerina Ooze forming at a very moderate depth (1142 fathoms). In Station 297 of the "Challenger," where there is also a Globigerina Ooze, the manganese nodules present are perfect nodules, and there is, moreover, a great abundance of palagonitic tuff, not met with in the case of this formation.

\section{Phosphatic Concretion.}

At Station 4642 (lat. $1^{\circ} 30.5^{\prime} \mathrm{S}$.; long. $89^{\circ} 35^{\prime} \mathrm{W}$.; depth, 300 fathoms; 7th November, 1904), the trawl brought up an irregularly-shaped phosphatic concretion, four inches long, reddish-brown, very hard, and of high specific gravity. A fresh fracture shows it to be composed of numerous shells of Foraminifera, cemented by a reddish-brown matrix of amorphous phosphate of lime. The carbonate of calcium amounts to 36.36 per cent, the remaining portion being composed of phosphate of lime, with a little iron oxide ( 2 or 3 per cent at most), and insoluble residue. The latter is formed of mineral particles represented principally by plagioclase and augite. No glauconite is present. The surface is slaggy-looking, vacuolar, and rough to the touch; the only places where it has a shining appearance are inside the larger vacuolæe. The nature of the surface is the same everywhere, and organisms are growing on it in different places, so that the nodule could not have been embedded to any great extent in the deposit.

\section{Sharks' Teeth and Cetacean Bones.}

The remains of whales and sharks brought up from the floor of the Pacific during this cruise of the "Albatross" were submitted to Dr. C. R. Eastman, who had previously reported ${ }^{1}$ on the similar remains procured by Dr. Alexander Agassiz on his earlier cruise in 1899-1900, and the following notes on the teeth and tympanic bones dredged at the various stations are taken from Dr. Eastman's report: ${ }^{2}$ -

"Station 4656, depth 2222 fathoms. There were brought up by the dredge from the bottom at this station 10 sharks' teeth, amongst which 4 are recognizable as belonging to the genus Lamna, 1 to Oxyrhina, 1 to Carcharodon, this last being a fine specimen, and the rest merely fragments. The cetacean material consisted of 1 tympanic bulla of Hyperoodon, 1 peri-

¿ Mem. Mus. Comp. Zoöl., Vol. XXVI., p. 179, 1903.

${ }_{2}$ Bull. Mus. Comp. Zoöl., Vol. L., pp. 30-82, 1906. 
otic of Kogia or some very similar form, and 1 indeterminate long and slender bone. Most of these remains are but slightly encrusted with manganese.

"Station 4658, depth 2370 fathoms. Four teeth of Oxyrhina, 9 Lamna, 2 nondescript fragments; also 1 delphinoid tympanic. Manganese coating very slight.

"Station 4666, depth 2600 fathoms. No fish remains ; 4 excellently preserved ear-bones of Hyperoodon, one having the tympanic still fused with the periotic ; also 1 heavily encrusted delphinoid tympanic, and several corroded osseous fragments.

"Station 4676, depth 2714 fathoms. No fish remains; 3 rather heavily encrusted ear-bones of Hyperoodon, . . . and 1 unrecognizable fragment.

"Station 4685, depth 2205 fathoms. This station, which lies within the barren area, is remarkable for having furnished a larger number of vertebrate remains than any other during the cruise, and with them were brought up $1_{2}^{\frac{1}{2}}$ tons of manganese nodules. There are in all 73 sharks' teeth, 5 of which belong to Carcharodon; the rest to Lamna and Oxyrhina. Some of the teeth are embedded in nodular masses; none have the crowns heavily encrusted, but the majority have dark-brown clay adhering to them. Cetaceans are represented by 5 delphinoid ear-bones; the tympano-periotic of one individual consists of a single piece.

"Station 4693, depth 1142 fathoms. According to the published record of 'Albatross' dredging stations, in the General Report of the Expedition," sharks' teeth and cetacean bones came up in the trawl at this locality. None such are contained, however, in the collection submitted for examination, the only specimen marked with this station number being a well preserved tergum of Lepas.

"Station 4695, depth 2020 fathoms. The vertebrate remains dredged at this point are confined to 2 small and tolerably fresh-looking Oxyrhina teeth.

"Station 4701, depth 2265 fathoms. Eight sharks' teeth, including 1 large and beautifully preserved Carcharodon, wholly unencrusted, also 1 large and 6 smaller Oxyrhina teeth, very lightly coated; 2 delphinoid ear-bones, likewise with very little coating.

"Station 4709, depth 2035 fathoms. Two small fresh-looking Lamna teeth; 2 heavily encrusted ear-bones of Hyperoodon, 1 indeterninate 
elongate bone, and several smaller fragments; also 9 lightly coated delphinoid ear-bones.

"Station 4711, depth 2240 fathoms. Two very slightly encrusted Lamna teeth; 2 delphinoid ear-bones, one being a large, very heavily encrusted tympanic, the other a moderately coated tympano-periotic; also a number of corroded fragments, all charged with manganese, and betraying only obscure indications of organic origin.

"Station 4721, depth 2084 fathoms. No fish remains; 4 delphinoid tympani; 3 specimens of Kogia, one having the tympanic and periotic fused, all lightly coated with manganese.

"Station 4732, depth 2012 fathoms. One splendidly preserved Carcharodon crown without manganese coating, but with several worm-tubes adhering to it; . . no cetacean bones. This and the next following station lie within the barren area.

"Station 4736, depth 2289 fathoms. One small Carcharodon, 6 Oxyrhina, 13 large-sized Lamna teeth, all stained dark brown and very thinly coated with manganese ; 3 delphinoid tympani, and 1 much decayed cetacean tooth corresponding in size to Hyperoodon, more or less chocolate-colored.

"Station 4740, depth 2422 fathoms. One splendidly preserved Carcharodon tooth ; . . . 1 Kogia, and 2 delphinoid ear-bones."

\section{Detalled Descriptions of the Deposit-Samples.}

(Numbered consecutively as collected; the stations marked with an asterisk are Hydrographic Stations where soundings alone were made.)

No. 1. Station 4630, 3rd November, 1904.

Lat. $6^{\circ} 53^{\prime} \mathrm{N}$. ; long. $81^{\circ} 42.5^{\prime} \mathrm{W}$.; depth, 556 fathoms.

GREEN SAND : dark green arenaceous material, which, when dried, is quite incoherent, thus showing the absence of clayey matter. The dried deposit is somewhat lighter in hue than the wet one.

Calcium carbonate : 5.23 per cent, essentially composed of Foraminifera, mostly Globigerinidæ, together with a few broken Echinoid spines.

REsIDUE : 94.77 per cent, same color and consistence as the deposit itself :Siliceous Organisms (1 per cent), represented by a few broken Sponge · spicules.

Minerals (90 per cent); if this sample really represents the deposit on the bottom of the sea, it is abnormally rich in minerals. As the minerals are essentially represented by glauconite, this deposit would be even richer 
THE DEPTH AND MARINE DEPOSITS OF THE PACIFIC OCEAN. 41 in that mineral than the one dredged by the U. S. S. "Tuscarora" in lat. $38^{\circ} 32^{\prime}$ N., long. $123^{\circ} 42^{\prime} \mathrm{W}$., which seemed to be the purest glauconitic sand previously known. Here the glauconite is wholly in the form of grains (not in that of casts), which are typically rounded in shape, and are ovoid and elongated, or approach a spherical form. Most of them are coated with a thin film of gray clayey matter, so that their real color can only be seen by transmitted light, after the grains have been crushed in a mortar in order to obtain particles sufficiently thin. The grains are not all identical; some are dark grass-green, some yellowish green, and half the bulk is transformed into a reddish-brown matter, where the crypto-crystalline structure is sometimes preserved when the transformation is not too far advanced. The mean diameter of the grains is $0.25 \mathrm{~mm}$., and the amount in which they are present is to the other minerals something like ten to one. The other minerals detected are quartz, and a plagioclase, probably andesine. Unlike the glauconite, these particles are angular; their mean diameter is also $0.25 \mathrm{~mm}$.

Fine Washings (3.77 per cent); as already stated, this percentage is not above doubt, as the deposit may have been subjected to washing. The fine washings are composed of very minute particles of glauconite and quartz, together with some green, very flocculent, amorphous matter.

No. 2. Station 4631, 3rd November, 1904.

Lat. $6^{\circ} 26^{\prime} \mathrm{N}$.; long. $81^{\circ} 49^{\prime} \mathrm{W}$.; depth, 776 fathoms.

GREEN MUD: grayish-green, very plastic and sticky when wet; coherent and forming hard lumps when dried. It contains pieces of black rock, one of them $1 \mathrm{~cm}$. in diameter.

Calcium carbonate: 25.20 per cent, Foraminifera, both surface and bottom living, for the greater part broken. Globigerina, Pulvinulina, Rotalia, Truncatulina, and Cristellaria are the most common genera. There are also a good many Echinoid spines.

Residue : 74.80 per cent:-

Siliceous Organisms (25 per cent), mostly gray, clayey casts of Foraminifera. Dark-brown casts do not appear to be present in this deposit. Actual siliceous organisms are here present in the form of Sponge spicules, which are much less abundant than the gray casts.

Minerals (25 per cent) ; besides one or two isolated particles of quartz, minerals are mainly represented by rock fragments and glauconitic grains. The rock fragments largely predominate, and vary much in size; the aver- 
age diameter of the more numerous fragments is $0.5 \mathrm{~mm}$, but one piece attains $1 \mathrm{~cm}$. in diameter. The rock is an augite-andesite, colored dark green by a high percentage of chloritic material. The fragments are angular, not rounded.

Fine Washings (24.80 per cent), brownish-green amorphous matter containing only a very few minute mineral particles.

No. 3. Station 4505, 5th November, 1904.

Lat. $3^{\circ} 11.6^{\prime} \mathrm{N}$. ; long. $84^{\circ} 57.4^{\prime} \mathrm{W}$; ; depth, 1705 fathoms.

GLOBIGERINA OOZE : dark gray, slightly plastic, dries into lumps coherent to a small extent only; no macroscopic elements.

Calcium carbonate: 38.35 per cent, shells, complete and broken, of Foraminifera belonging mostly to the genera Globigerina and Pulvinulina, Echinoid spines, coccoliths, and rhabdoliths.

Residue : 61.65 per cent:-

Siliceous Organisms ( 0.5 per cent), a few Sponge spicules, Radiolaria, and diatoms.

Minerals (1.5 per cent), a few grains of pale augite and magnetite with a mean diameter of $0.2 \mathrm{~mm}$. These minerals are masked by an abundance of small gray lumps, recalling in their general appearance comminuted pumice. One fragment of volcanic glass was detected, which probably belonged to a piece of Pele's hair, as it is rod-like and semi-circular, with the bore occupying the greater part of the diameter.

Fine Washings (59.65 per cent), amorphous, flocculent matter, brown when wet, gray when dry, in which exceedingly minute particles of angite can be seen, but in small amount, together with broken Sponge spicules.

The following is a list $^{1}$ of the species of Foraminifera observed in the deposit from this station:-

Biloculina depressa, d'Orb.

" " var. murrhyna, Schw.

" irregularis, d'Orb.

Spiroloculina tenuis (Czjzek).

Miliolina tricarinata (d'Orb.).

" trigonula (Lamk.).

Haplophragmium nanum, Brady.

anceps, Brady.

Haplophragmium emaciatum, Brady.

Verneuilina pygmaa (Egger).

Gaudryina pupoides, d'Orb.

$$
\text { " " var. chilostoma, Rss. }
$$

Bulimina elegans, d'Orb., var. exilis, Brady.

Ehrenbergina serrata, Rss.

Lagena sulcata (W. \& J.), var. interrupta, Will.

1 The lists of species of Foraminifera in the deposits from Stations 4505, 4691, 4705, and 4717 have been drawn up by Mr. F. G. Pearcey, formerly an assistant in the Challenger Office, now of the Bristol Museum. 
Lagena alveolata, Brady.

" exsculpta, Brady.

" gracilis, Will.

" feildeniana, Brady.

Polymorphina angusta, Egger (?).

Uvigerina brunnensis, Karrer.

" asperula, Czjzek.

" " var. ampullacea, Brady.

" tenuistriata, Rss.

Truncatulina ungeriana (d'Orb.).

" akneriana (d'Orb.).

" wuellerstorfi (Schw.).

Anomalina ammonoides (Rss.).

Pulvinulina menardii (d'Orb.).

$\begin{array}{ll}\text { " } & \text { " var. fimbriata, Brady. } \\ \text { "6 } & \text { micheliniana (d'Orb.). } \\ \text { " } & \text { canariensis (d'Orb.). } \\ \text { " } & \text { karsteni (Rss.). } \\ \text { " } & \text { exigua, Brady. } \\ \text { " } & \text { crassa (d'Orb.). }\end{array}$

Pulvinulina umbonata, Rss.

" pauperata, P. \& J.

Rotalia brockhiana, Kar.

" soldanii, d'Orb.

Globigerina dubia, Egger.

" rubra, d'Orb.

" inflata, d'Orb.

" sacculifera, Brady.

" conglobata, Brady.

" bulloides, d'Orb.

" " var. triloba, Rss.

"aquilateralis, Brady.

" pachyderma (Ehrenb.) (?).

Orbutina universa, d'Orb.

" porosa, Terq.

Pullenia obliquiloculata, P. \& J.

" quinqueloba, Rss.

" sphceroides (d'Orb.).

Nonionina umbilicatula (Montag.).

" pompilioides (F. \& M.).

No. 4. Station 4639, 6th November, 1904.

Lat. $0^{\circ} 4^{\prime}$ S. ; long. $87^{\circ} 39.5^{\prime}$ W.; depth, 1418 fathoms.

GLOBIGERINA OOZE: gray, plastic, drying into hard lumps; no macroscopic elements.

Calcium carbonate : 55.57 per cent, present in two forms: (1) as shells of Foraminifera belonging to the genera Globigerina and Pulvinulina, and (2) as microscopic particles due probably to the mechanical destruction of similar shells; these form a fine mud easily washed away, so that the liquid containing them effervesces readily with acid.

Residue : 44.43 per cent :-

Siliceous Organisms ( 0.5 per cent); these form the greater part of the heavier parts of the residue. They are represented by a great variety of Radiolaria in a fine state of preservation, by Sponge spicules, and by Diatoms.

Minerals (traces); they can be estimated only as traces, as they are present with the siliceous organisms in the proportion of one mineral particle to every ten organisms. They are angular, and the mean diameter is $0.05 \mathrm{~mm}$. Pale augite is the principal constituent, and is accompanied by a very little magnetite and a few shapeless flakes of some kind of green chlorite. 
Fine Washings (43.93 per cent), earthy-brown in color when in great quantity, composed of amorphous clayey matter, together with numerous Radiolaria and Diatoms, which were too light to remain with the heavier portions. The mineral particles present are exceedingly small, but augite can still be recognized.

No. 5. Station 4641, 7th November, 1904.

Lat. $1^{\circ} 34.4^{\prime} \mathrm{S}$. ; long. $89^{\circ} 30.2^{\prime} \mathrm{W}$.; depth, 633 fathoms.

GLOBIGERINA OOZE: gray, with very little coherence, has a distinct greenish tinge, very homogeneous, no macroscopic elements present.

Calcium Carbonate : 75.00 per cent, well-preserved shells of Foraminifera, belonging principally to the genera Globigerina and Pulvinulina; young individuals are specially abundant. Other organisms were not detected.

Residue : 25.00 per cent :-

Siticeous Organisms ( 1.5 per cent), gray clayey casts of Foraminifera, perfect in shape, predominate over the organisms proper; Sponge spicules are abundant, and in a good state of preservation, and parts of the skeletons of Hexactinellidæ may be seen. Many Radiolaria and Diatoms are present, together with a few glauconitic casts and arenaceous Foraminifera.

Minerals (1 per cent), all angular excepting the few glauconitic grains present; their mean diameter is $0.15 \mathrm{~mm}$. The most typical mineral in this deposit is augite, which is represented by two varieties: the ordinary light brown, and the violet; magnetite is fairly abundant, and so is hematite. A red shapeless mineral is frequently observed, but cannot be determined, as it is doubtless in course of decomposition, being sometimes translucid and birefringent, sometimes quite opaque. Plagioclase is also met with, and also many minute splinters of colorless volcanic glass. Common green hornblende is present in small amount. Of glauconite only a few rounded grains could be detected.

Fine Washings (22.5 per cent); in a gray-brown clayey ground-mass are many minute fragments of Sponge spicules, Diatoms, and Radiolaria, accompanied by the above minerals, principally augite. A very flocculent green matter, floating in water, gives its color to the deposit.

No. 6. Station 4649, 10th November, 1904.

Lat. $5^{\circ} 17^{\prime}$ S. ; long. $85^{\circ} 19.5^{\prime} \mathrm{W}$.; depth, 2235 fathoms.

RED CLAY: dark gray, plastic, drying into hard coherent lumps of a lighter shade of gray. 
THE DEPTII AND MARINE DEPOSITS OF THE PACTFIC OCEAN. 45

Calcium carbonate: 20.46 per cent, Foraminifera, mostly Globigerinidx, the individuals being of very small size, but in a good state of preservation, and Echinoid spines.

REsidue : 79.54 per cent, earthy brown in color, and very fine grained:-

Siliceous Organisms (3.5 per cent); Radiolaria are very abundant and of large size, and form the greater part of the heavier portion of the residue. There are also a good many Diatoms, and some Sponge spicules.

Minerals (traces); the mineral particles are so small and few in number that they cannot be all identified. Magnetite, hematite, quartz, and a little glauconite could be recognized. Particles having the appearance of hornblende, augite, and zircon may be mentioned, but their identification is very doubtfuil.

Fine Washings (76.04 per cent); gray, somewhat brownish, matter, very clayey, containing a great number of Diatoms, together with a few Sponge spicules and minute mineral particles.

No. 7. Station 4654,12 th November, 1904.

Lat. $5^{\circ} 46^{\prime} \mathrm{S}$. ; long. $81^{\circ} 31.9^{\prime} \mathrm{W}$.; depth, 1036 fathoms.

GREEN MUD : dark green, very plastic and smooth to the touch, drying into hard, coherent lumps. The dried material, powdered in a mortar, has a vivid light-green color.

Calcium CARBonate: traces; with acid the deposit gives hardly any effervescence, and only one or two pelagic Foraminifera could be detected.

Residue : 100 per cent :-

Siticeous Organisms (traces), only one or two Sponge spicules and Diatoms.

Minerals (12.5 per cent), angular and rounded, mean diameter 0.15 mm.; of terrigenous minerals the most common are quartz and felspar. Of the latter, two varieties appear to co-exist: some fragments have the optical properties of an oligoclase containing 30 per cent of anorthite; others belong to bytownite. Both these are in fairly large crystals, but, besides, there are many microlites belonging presumably to oligoclase. One or two small fragments of colorless volcanic glass are also present. Magnetite is represented in very small amount, and so also is white mica, in scales that have lost much of their transparency. A mineral not often met with, namely, chalcedony, is also to be seen, as small rounded fragments exhibiting the phenomenon of the black cross between crossed nicols in parallel light. 
Glauconite is very abundant as grains, the green color varying in intensity and hue, some grains being grass green, others rather yellowish.

Fine Washings (87.5 per cent); principally minute particles of the minerals above mentioned, which passed away with the clayey matter, with a few fragmentary Diatoms and Sponge spicules and fine flocculent clayey matter colored green by the adjunction of the green matter usually met with in Green Muds and Sands.

No. 8. Station 4658, 14th November, 1904.

Lat. 8. 29.5' S.; long. $85^{\circ} 35.6^{\prime} \mathrm{W}$; ; depth, 2370 fathoms.

RED CLAY: gray, sticky, plastic, fine-grained, very smooth to the touch; dries into very hard lumps slightly reddish in tinge. The clay proper is quite homogeneous, but contained many manganese nodules, sharks' teeth, and cetacean ear-bones.

Calcium carbonate: 0 per cent.

Residue: 100 per cent :-

Siliceous Organisms (0.5 per cent), many different genera of arenaceous Foraminifera are present, including Haplophragmium; also a few Sponge spicules and Diatoms.

Minerals (4 per cent); not taking into account the broken fragments of manganese nodules, the mineral particles consist mostly of small grains $(0.5$ $\mathrm{mm}$. in diameter) of the oxides of iron and manganese, together with a very few particles of plagioclase, augite, magnetite, and hematite.

Fine Washings (95.5 per cent) ; principally a dark gray amorphous clay, with a few microscopic mineral particles not determinable, and a few Diatoms.

No. 9. Station 4666, 18th November, 1904.

Lat. $11^{\circ} 55.5^{\prime} \mathrm{S}$, ; long. $84^{\circ} 20.3^{\prime} \mathrm{W}$.; depth, 2600 fathoms.

RED CLAY : gray, typically clayey, plastic, sticky, smooth to the touch, drying into hard lumps.

Calcium carbonate: traces. Acid caused effervescence in one or two spots only. A pelagic Foraminifer was detected, and unrecognizable tabular fragments.

REsIdUe : 100 per cent :-

Siticeous Organisms (1 per cent), principally Sponge spicules, with Radiolaria and arenaceous. Foraminifera. 
THE DEPTH AND MARINE DEPOSITS OF THE PACIFIC OCEAN. 47

Minerals (2.30 per cent); the mineral particles here may be roughly divided into two groups according to size, - one has a mean diameter of $0.12 \mathrm{~mm}$., the other about $1 \mathrm{~mm}$. There are two fragments of rock, 2 and $3 \mathrm{~mm}$. in diameter, irregular, with blunted edges, brown and soft, representing a decomposed volcanic rock, and consisting essentially of limonite and a glassy base, in which augite and a tabular isotropic mineral are observed. To these fragments are firmly attached Sponge spicules forming on their surface a reticulated design: The minerals proper consist of quartz, in fragments sometimes $1 \mathrm{~mm}$. in diameter, with blunted edges, augite, a little plagioclase, a few flakes of a chloritic mineral, and a good many manganese grains. Many splinters of colorless volcanic glass were also observed, in addition to flakes of hematite.

Fine Washings (96.70 per cent), yellowish-gray clayey matter, with a few small mineral particles.

No. 10. Station 4671, 20 th November, 1904.

Lat. $12^{\circ} 6.9^{\prime}$ S. ; long. $78^{\circ} 28.2^{\prime}$ W.; depth, 1490 fathoms.

BLUE MUD : dark green when wet, very soft to the touch, and plastic, but not sticky; when dried, slightly coherent and light gray in color with a faint green tinge.

Calcium carbonate: 0 per cent.

Residue : 100 per cent :-

Siticeous Organisms ( 0.5 per cent), only Diatoms were observed.

Minerals ( 0.5 per cent), very few, angular and varying in size, mostly quartz and glauconite, with a little felspar, magnetite, and hematite.

Fine Washings (99 per cent), fine greenish-colored clay, containing many very minute mineral particles, $0.01 \mathrm{~mm}$. in diameter, and Diatoms.

No. 11. Station 4672,21 st November, 1904.

Lat. $13^{\circ} 11.6^{\prime}$ S. ; long. $78^{\circ} 18.3^{\prime} \mathrm{W}$.; depth, 2845 fathoms.

RED CLAY (might be called Blue Mud): gray, plastic, sticky, smooth to the touch; dries into light-gray lumps difficult to break. The deposit has undergone a kind of decomposition in the bottle, as parts of it have turned nearly black.

Calcium carbonate: 0 per cent.

Residue : 100 per cent :- 
Siticeous Organisms (small traces), a very few thin Sponge spicules and one or two Diatoms.

Minerals (traces), angular quartz grains, $0.08 \mathrm{~mm}$. in diameter, shapeless flakes of a green chlorite, one or two fragments of decomposed felspar, and a particle of manganese are all that could be detected.

Fine Washings (100 per cent), gray, flocculent clay, containing a large proportion of minute mineral particles as mentioned above, with augite, hematite, and perhaps hornblende, and a few fragments of siliceous organisms. The mineral particles represent nearly one-half the bulk of the deposit, but they are very small, averaging $0.01 \mathrm{~mm}$. in diameter.

No. 12. Station 4509, 22nd November, 1904.

Lat. $12^{\circ} 26.6^{\prime} \mathrm{S}$. ; long. $78^{\circ} 34.5^{\prime} \mathrm{W}$.; depth, 1949 fathoms.

BLUE MUD : very dark gray, almost black, plastic, but not sticky, finely granular; much lighter in color when dry.

Calcium CARBonate : 5.07 per cent, well preserved shells of Foraminifera belonging to many genera, Textularidæ being the most abundant.

RESIDUE : 94.93 per cent, contains a brown matter apparently of vegetable origin. The material appears to have undergone a certain amount of sifting, either during collection or during transit, for mineral particles are more abundant in some parts than in others, so that the figures given for the percentages of siliceous organisms and minerals are only approximate :-

Siliceous Organisms (0.5 per cent), Sponge spicules and Diatoms.

Minerals (3.5 per cent), angular; mean diameter $0.08 \mathrm{~mm}$., principally quartz and plagioclase, with a chloritic mineral and other ferruginous, decomposed minerals that could not be identified.

Fine Washings (90.93 per cent), brown, amorphous, flocculent matter, with many fragments of minerals and siliceous organisms.

No. 13. Station 4674, 22nd November, 1904.

Lat. $12^{\circ} 14.4^{\prime} \mathrm{S}$; long. $78^{\circ} 43.4^{\prime} \mathrm{W}$.; depth, 2338 fathoms.

The material obtained at this station is extremely interesting, consisting of (1) a bottle of ooze, (2) cakes of consolidated sediment, apparently the same as No. 1, and (3) large angular fragments of rocks, some of them over a foot in diameter.

(1) DIATOM OOZE: dark grayish green, mottled with lighter colored 
patches; placed in water it becomes plastic, but is coherent when dried. Numerous pebbles, from 1 to $15 \mathrm{~mm}$. in diameter, are scattered in the mass.

Calcium carbonate: 0 per cent.

REsidue : 100 per cent :-

Siliceous Organisms (80 per cent) constitute by far the greater portion of the deposit, but as they are mixed with a certain proportion of fine amorphous clayey matter it is difficult to estimate the actual percentage. It is also impossible to draw the line between those that should be included under the heading of "fine washings." Yet it may safely be assumed that quite 80 per cent of the deposit is formed of the remains of siliceous organisms. Diatoms are the most abundant, and are accompanied by Radiolaria and minute Sponge spicules.

Minerals (traces); exclusive of the rock fragments, mineral particles are few in number, are all angular, none showing rounded edges, and are very variable in size (from less than $0.01 \mathrm{~mm}$. to $0.2 \mathrm{~mm}$. in diameter). They were probably not all derived from the same source, as is indicated by the nature of the rock fragments. The following are represented: magnetite, oxidized at the surface, oligoclase, quartz, the products of the decomposition of some ferro-magnesian mineral, also rather large flakes of what appears to be decomposed biotite, splinters of volcanic glass, and a few very small grains of glauconite. The numerous rock fragments are represented mostly by a limestone, which is the same as that constituting the large angular blocks, No. 3. These small fragments of limestone are sometimes rounded, sometimes angular, and have all undergone surface decomposition. There is also a pebble, $15 \mathrm{~mm}$. in diameter, of a compact black rock, apparently of volcanic origin, much rounded, smooth, and worn.

Fine Wastings (20 per cent); the amorphous clayey matter is brownish green and is irregularly distributed. The mottled appearance of the deposit is due to this unequal distribution of the amorphous matter, or rather of the substance giving it its brownish green color.

(2) The cakes of consolidated deposit, labelled "Siliceous earth" on board ship, are greenish gray, extremely light, and coherent. They differ in no way from the material in the bottle, being mainly made up of the débris of siliceous organisms, in which a species of Coscinodiscus is conspicuous. The mineral particles belong to the same species as those enumerated above, and are very scarce. Particles of what appears to be glauconite were also detected. 
(3) The large rock fragments are broken masses of an impure limestone, showing in some cases traces of bedding, whilst other blocks are compact. A microscopic slide showed no trace of organisms, but the blocks were subsequently broken into smaller fragments, and in some parts numerous shells of Foraminifera belonging to one of the Textularidæ (probably Bolivina) could be seen crowded together. The same fossil occurs in the small pebbles described above.

An unusual interest attaches to this deposit: a Diatom Ooze formed in tropical latitudes, and yet free from the remains of lime-secreting organisms. It is also curious that it should contain so many large fragments of rocks of continental origin, and that small mineral particles should be so scarce. It may be that in this case the large masses have not the same source as the mineral particles, but were carried to this point by some such agent as the roots of a floating tree, and that they happened to be in the way of the trawl, although otherwise quite rare. The descriptions of the samples from neighboring stations show that the abundant deposition of siliceous remains in this region is extremely local.

No. 14. Station 4675, 22nd November, 1904.

Lat. $12^{\circ} 54^{\prime} \mathrm{S}$. ; long. $78^{\circ} 33^{\prime} \mathrm{W}$.; depth, 3120 fathoms.

RED CLAY: very little material available, greenish-brown, soft, and plastic, emitting a faint mouldy smell.

Calcium carbonate: 0 per cent.

Residue: 100 per cent:-

Siliceous Organisms ( 0 per cent); none could be observed in the portion of the sample taken for examination.

Minerals (traces), angular, mean diameter $0.06 \mathrm{~mm}$; augite and felspar are the principal constituents; felspars are represented by oligoclase and andesine; common grass-green hornblende is also fairly abundant. Strangely enough, a few undoubted rounded grains of glauconite are to be found, differing in no way from the typical glauconitic grains of a Green Mud.

Fine Washings (nearly 100 per cent), greenish-brown, flocculent matter, with a very large proportion of minute particles of the above-mentioned minerals. 
THE DEPTH AND MARINE DEPOSITS OF THE PACIFIC OCEAN. 51

No. 15. Station 4676, 5th December, 1904.

Lat. $14^{\circ} 28.9^{\prime} \mathrm{S}$. ; long. $81^{\circ} 24^{\prime} \mathrm{W}$.; depth, 2714 fathoms.

RED CLAY : brown, plastic and sticky, drying into hard, gray lumps with a reddish tinge.

Calcium carbonate: 0 per cent.

Residue : 100 per cent :-

Siliceous Organisms (traces), a few Sponge spicules and Diatoms.

Minerals (traces), one or two minute manganese grains, and mineral particles too small to be determined.

Fine Washings (nearly 100 per cent), brown flocculent clay, with very few minute mineral particles and remnants of Sponge spicules.

No. $16 . \quad$ Station 4679, 7th December, 1904.

Lat. $17^{\circ} 26.4^{\prime} \mathrm{S}$; ; long. $86^{\circ} 46.5^{\prime} \mathrm{W}$.; depth, 2485 fathoms.

RED CLAY : typical, light-brown clay, very plastic and sticky, drying into hard lumps, reddish in hue.

Calcium carbonate: 0 per cent.

Residue: 100 per cent:-

Siliceous Organisms (traces), a few Sponge spicules only.

Minerals (traces); most of the particles are so small $(0.005 \mathrm{~mm}$. in diameter) that they cannot be determined. One large crystal of felspar, with perfect prismatic faces, was observed, and also a few small manganese grains. An elongated fragment of pumice, one inch long, is the only macroscopic element present.

Fine Washings (nearly 100 per cent), amorphous, light-brown clayey matter, with many very minute mineral particles.

No. 17. Station 4681, 8th December, 1904.

Lat. $18^{\circ} 47.1^{\prime} \mathrm{S}$; ; long. $89^{\circ} 26^{\prime} \mathrm{W}$.; depth, 2395 fathoms.

RED CLAY : typical, light brown clay, very plastic, forming extremely hard lumps when dried; shining brown streak.

Calcium carbonate: 4.23 per cent, Foraminifera belonging to the genus Pulvinulina, and Fishes' teeth.

Residue : 95.77 per cent :-

Siliceous Organisms (traces), Sponge spicules.

Minerals (traces), a few irregular manganese grains, and angular fragments of felspar, $0.2 \mathrm{~mm}$. in diameter. 
Fine Washings (95.77 per cent), practically pure flocculent clay. The mineral particles present are so small that they cannot be determined; one or two remnants of Sponge spicules.

No. 18. Station 4683, 9th December, 1904.

Lat. $20^{\circ} 2.4^{\prime} \mathrm{S}$. ; long. $91^{\circ} 52.5^{\prime} \mathrm{W}$.; depth, 2385 fathoms.

RED CLAY: the little material available is quite similar to Nos. 16 and 17.

Calcium carbonate: 3 per cent, Pulvinulinidæ.

REsidue : 97 per cent :-

Siticeous Organisms (traces), a few Sponge spicules.

Minerals (traces); the most abundant mineral is phillipsite in crystals, 0.03 to $0.04 \mathrm{~mm}$. in length, and $0.01 \mathrm{~mm}$. in breadth; also a few manganese grains. The other mineral particles are too small $(0.01 \mathrm{~mm}$. in diameter) to be determined, but still they are probably mostly augite, in angular fragments.

Fine Washings (97 per cent), flocculent reddish-brown clay, with a few minute mineral particles.

No. 19. Station 4685, 10th December, 1904.

Lat. $21^{\circ} 36.2^{\prime} \mathrm{S}$.; long. $94^{\circ} 56^{\prime} \mathrm{W}$. ; depth, 2205 fathoms.

GLOBIGERINA OOZE: dark brown, plastic and sticky, of mottled appearance, light yellow patches showing in the dark mass; contains many manganese nodules; reddish and coherent when dried; might be called Red Clay.

Calcium carbonate: 34.07 per cent-mean of two determinations; Foraminifera and a few Fishes' teeth.

Residue : 65.93 per cent :-

Siticeous Organisms (1 per cent), Sponge spicules.

Minerals (2.5 per cent), angular, mean diameter $0.2 \mathrm{~mm}$., mostly manganese grains, and next in order of abundance, palagonite, small fragments of rocks, magnetite, augite, and volcanic glass.

Fine Washings (62.43 per cent), brown amorphous clayey matter, containing a few very small manganese grains and a great number of minute crystalline particles. 
No. 20. Station 4687, 11th December, 1904.

Lat. $22^{\circ} 49.5^{\prime}$ S. ; long. $97^{\circ} 30.6^{\prime}$ W. ; depth, 2184 fathoms.

RED CLAY : dark chocolate-brown clay, plastic and sticky, drying into hard lumps; a few Foraminifera visible to the naked eye as white specks.

Calcium carbonate: 8.13 per cent; pelagic Foraminifera, mostly broken, but individuals belonging to the genus Pulvinulina are recognizable; also a good many Fishes' teeth.

Residue: 91.87 per cent :-

Siliceous Organisms (traces), a few Sponge spicules.

Minerals (traces), a few particles from 0.1 to $0.3 \mathrm{~mm}$. in diameter, with some much smaller; manganese grains and palagonite are the most frequent; augite, volcanic glass, and phillipsite were also detected, but are very rare.

Fine Washings (91.87 per cent), dark-brown clay with many microscopic crystals of phillipsite, fragments of augite and other particles undeterminable, and of Sponge spicules.

No. 21. Station 4689, 12 th December, 1904.

Lat. $24^{\circ} 5^{\prime} \mathrm{S}$; ; long. $100^{\circ} 20^{\prime} \mathrm{W}$.; depth, 2185 fathoms.

RED CLAY : dark chocolate-brown clay, plastic and sticky, very hard when dried; fragments of Foraminifera visible to the naked eye.

Calcium carbonate: 13.94 per cent, pelagic Foraminifera and Fishes' teeth.

Residue : 86.06 per cent :-

Siticeous Organisms (small traces), only a few fragmentary Sponge spicules could be detected.

Minerals (traces), angular and rounded, ranging from 0.01 to $0.10 \mathrm{~mm}$. in diameter; plagioclase and augite can be recognized, with small isolated crystals of phillipsite, $0.06 \mathrm{~mm}$. long and $0.01 \mathrm{~mm}$. broad. A little magnetite is present, but the other particles are too minute for determination.

Fine Washings (\$6.06 per cent), brown clayey matter with minute mineral particles.

No. 22. Station 4691, 13th December, 1904.

Lat. $25^{\circ} 27.3^{\prime}$ S. ; long. $103^{\circ} 29.3^{\prime} \mathrm{W}$.; depth, 1939 fathoms.

GLOBIGERINA OOZE : light brown, plastic and sticky, drying into slightly coherent gray lumps, with a reddish tinge. 


\section{THE DEPTH AND MARINE DEPOSITS OF THE PACIFIC OCEAN.}

Calcium carbonate : 70.40 per cent, pelagic and bottom-living Foraminifera, Ostracodes, rhabdoliths, and coccoliths.

Residue : 29.60 per cent, dark chocolate-brown, very clayey :-

Siliceous Organisms (traces); out of 22 grams of dried ooze there remained after washing only one or two centigrams of mineral particles and siliceous organisms of appreciable size, so that the part played by them is insignificant. The more abundant siliceous organisms are arenaceous Foraminifera and brown, imperfect casts of pelagic Foraminifera. Sponge spicules and Radiolaria are present, but very rare.

Minerals (traces); one piece of palagonite, $2 \mathrm{~mm}$. in diameter, a few manganese grains, $0.3 \mathrm{~mm}$. in mean diameter, one or two fragments of colorless volcanic glass, crystals of plagioclase, and a little magnetite are all that could be detected. This deposit contains a good many pieces of rock, ranging from $\frac{1}{4}$ inch to 2 inches in diameter. Most of them have very blunted edges, though they cannot be described as rounded; one or two pieces, on the other hand, are quite angular. The rock is very dark gray, nearly black, and weathers brown; it is an augite-andesite, the glassy base of which has decomposed and has been changed into an amorphous ferruginous clay. Some pieces have "druses" coated with a thin layer of manganese oxide.

Fine Washings (29.60 per cent), chocolate-brown, flocculent clay, remarkably free from mineral particles and organic remains.

The following is a list of the species of Foraminifera observed in the deposit from this station:-

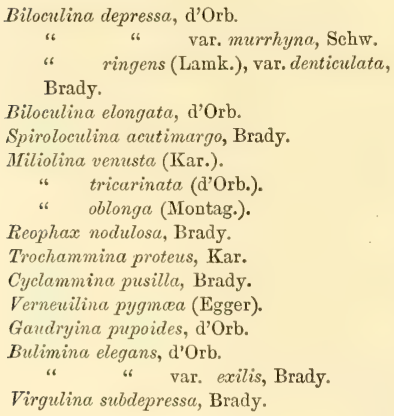

Virgulina schreibersiana, Czjzek. Cassidulina subglobosa, Brady. " erassa, d'Orb.

Lagena acuta (Rss.), var.

" alveolata, Brady.

" desmophora, Ry. Jones.

" exsculpta, Brady.

"s globosa (Montag.).

"f fimbriata, Brady.

Cristellaria convergens, Bornem.

Uvigerina asperula, Czjzek.

Globigerina conglobata, Brady.

" sacculifera, Brady.

Globigerina mubra, d'Orb.

" bulloides, d'Orb.

" " var. triloba, Rss.

“ dubia, Egger. 
Globigerina inflata, d'Orb.

" aquilateralis, Brady.

Orbulina universa, d'Orb.

Pullenia quinqueloba, Rss.

“ spharoides (d'Orb.).

Spharoidina dehiscens, P. \& J.

Candeina nitida, d'Orb.

Cymbalopora poeyi (d'Orb.) (?).

Discorbina eximia, Hantk. (?).

" bertheloti (d'Orb.), var. baconica, Hantk.

Discorbina araucana (d'Orb.).

Truncatulina wuellerstorfi (Schw.).
Truncatulina ungeriana (d'Orb.).

" lobatula (W. \& J.).

Pulvinulina micheliniana (d’Orb.).

" crassa (d'Orb.).

" menardii (d'Orb.).

" tumida, Brady.

“ exigue, Brady.

" umbonata, Rss.

" favus, Brady.

" karsteni (Rss.).

" canariensis (d'Orb.).

Nonionina umbilicatula (Montag.).

No. 23. Station $4514^{*}$ (hydrographic), 15th December, 1904.

Lat. $27^{\circ} 16^{\prime}$ S. ; long. $108^{\circ} 56^{\prime}$ W.; depth, 1552 fathoms.

VOLCANIC SAND : brown, having an earthy texture and a mottled appearance due to the presence of yellow patches; incoherent and not plastic when wet. A decomposed soft piece of pumice (1 1 inches in diameter), coated with manganese, was picked out.

Calcium carbonate : 11.81 per cent, various species of pelagic Foraminifera; other organisms were not detected.

Residue: 88.19 per cent:-

Siliceous Organisms (traces), a few Sponge spicules sticking to the surfaces of some of the larger mineral particles.

Minerals (19.48 per cent), principally fragments of decomposed pumice and grains of the oxides of iron and manganese ( 1 to $2 \mathrm{~mm}$. in diameter), the latter containing much more iron than manganese. The actual mineral particles are angular, and have a mean diameter of $0.2 \mathrm{~mm}$; they are represented by common augite and olivine, and by plagioclase particles, which could not be accurately determined; there is also the yellow, opaque product of decomposition of some ferruginous mineral.

Fine Washings (68.71 per cent), mostly fine mineral particles, with a very little clayey matter.

No. 24. Station 4516, 22nd December, 1904.

Lat. $26^{\circ} 54.8^{\prime}$ S. ; long. $109^{\circ} 16.4^{\prime}$ W. ; depth, 1627 fathoms.

GLOBIGERINA OOZE: fine-grained, plastic, gray, drying into chalky lumps having little coherence; contains one angular rock fragment a quarter of an inch in diameter.

Calcium carbonate: 33.33 per cent; pelagic Foraminifera (Globigerina, 
Pulvinulina, Orbulina) and their fragments form the greater part of the calcium carbonate, with one or two bottom-living forms (Biloculina depressa) and a few Echinoid spines.

Residue : 66.67 per cent :-

Siticeous Organisms (0 per cent); none could be detected.

Minerals (5 per cent), all the particles are angular, and their mean diameter is a little under $0.1 \mathrm{~mm}$. Of determinable mineral particles common augite is the most frequent, while felspar is also very abundant, and could be accurately determined as labradorite $\left(A b_{1} A_{1}\right)$. There are also many minute fragments of magnetite. The remaining portion is represented by the brown product of decomposition of some ferro-magnesian mineral. The fragment of rock is a hard, vitreous, black, volcanic glass, without any trace of crystallization.

Fine Washings (61.67 per cent), brown, amorphous clayey matter, with numerous minute mineral particles.

No. 25. Station 4517,* 22nd December, 1904.

Lat. $26^{\circ} 50.9^{\prime} \mathrm{S}$. ; long. $109^{\circ} 12.5^{\prime} \mathrm{W}$.; depth, 1723 fathoms.

GLOBIGERINA OOZE: light-brown, slightly plastic, drying into reddishbrown lumps that have little coherence.

Calcium Carbonate : 63.55 per cent, many species of pelagic Foraminifera, including numerous small individuals; one Echinoid spine was detected.

REsidue: 36.45 per cent, dark brown:-

Siliceous Organisms (traces), only a few arenaceous Foraminifera and Sponge spicules.

Minerals (2.50 per cent), mostly angular; augite plays the principal rôle ; magnetite comes next in order of abundance, and there are a good many microlites of basic plagioclase. Volcanic glass was not observed.

Fine Washings (33.95 per cent), dark-brown clay with minute mineral particles.

No. 26. Station 4518, 22nd December, 1904.

Lat. $26^{\circ} 47.3^{\prime}$ S.; long. $109^{\circ} 9.3^{\prime} \mathrm{W}$.; depth, 1770 fathoms.

GLOBIGERINA OOZE: light brown, plastic, but not sticky; reddishbrown and slightly coherent when dry.

Calcium carbonate: 53.01 per cent, Foraminifera, most of the individuals being of small size, and Echinoid spines. 
RESIDUE : 46.99 per cent, dark chocolate-brown:-

Siliceous Organisms (traces), Sponge spicules, spherical Radiolaria, and a few arenaceous Foraminifera.

Minerals (1.4 per cent), angular; mean diameter $0.1 \mathrm{~mm}$., principally augite; magnetite is abundant, mostly as particles firmly attached to other minerals; felspars belonging to basic plagioclases are present, but cannot be specifically determined; also brownish and greenish products of decomposition of some minerals, augite amongst others, as one particle of augite is seen to pass laterally into a greenish-brown amorphous substance; a few flakes of hematite.

Fine Washings (45.59 per cent), very flocculent, brown clay, with a few mineral particles and siliceous remains.

No. 27. Station 4695, 23rd December, 1904.

Lat. $25^{\circ} 22.4^{\prime}$ S. ; long. $107^{\circ} 45^{\prime} \mathrm{W}$.; depth, 2020 fathoms.

GLOBIGERINA OOZE: chestnut-brown, plastic and sticky; dries into light reddish-gray coherent lumps.

Calcium carbonate : 62.30 per cent, pelagic Foraminifera, mostly broken shells and rather small individuals; Fishes' teeth and Echinoid spines.

RESIDUE : 37.70 per cent, rich chestnut-brown :-

Siliceous Organisms (traces), a few Sponge spicules and arenaceous Foraminifera.

Minerals ( 0.5 per cent), angular; mean diameter $0.1 \mathrm{~mm}$., with fragments of palagonite $1 \mathrm{~mm}$. in diameter, and a reddish decomposed fragment of rock, $3 \mathrm{~mm}$. in diameter. Augite, plagioclase (labradorite), magnetite, and manganese grains are equally abundant. Of the minerals forming the fragment of rock alluded to, only a few crystals of augite and plagioclase have escaped decomposition, the remaining portion being transformed into an amorphous reddish-brown substance. The trawl also brought up fragments of pumice, volcanic glass, and palagonitic tuff, described elsewhere.

Fine Washings (37.20 per cent), dark chestnut-brown flocculent clay, very free from admixtures of mineral particles, though a few of these can be seen.

No. 28. Station 4697, 24th December, 1904.

Lat. $23^{\circ} 24.4^{\prime}$ S. ; long. $106^{\circ} 2.2^{\prime}$ W. ; depth, 2188 fathoms.

RED CLAY : very dark chocolate-brown, with yellowish patches; dries into hard lumps, giving a shining brown streak. 
Calcium carbonate : 11.12 per cent, pelagic Foraminifera of small size and generally broken.

RESIDUE : 88.88 per cent: -

Siliceous Organisms (traces), a few Sponge spicules and arenaceous Foraminifera.

Minerals (traces); most of the mineral particles pass off with the "fine washings," those of appreciable size (exceeding $0.05 \mathrm{~mm}$. in diameter) being very few in number, and consisting of plagioclase, augite, and manganese grains.

Fine Washings (88.88 per cent), chocolate-brown flocculent clay, with a few very minute mineral particles too small $(0.005 \mathrm{~mm}$. in diameter) to be determined.

No. 29. Station 4699, 25th December, 1904.

Lat. $21^{\circ} 39.5^{\prime}$ S.; long. $104^{\circ} 29.8^{\prime}$ W. ; depth, 2168 fathoms.

GLOBIGERINA OOZE: plastic and sticky, smooth to the touch; the sample is partly dark brown, partly light yellowish-brown; dries into hard lumps; might be called Red Clay.

Calcium Carbonate: 33.02 per cent, pelagic Foraminifera, mostly broken, with a few small transparent bottom-living Foraminifera.

REsidue : 66.98 per cent :-

Siliceous Organisms (traces), one or two Sponge spicules. Radiolaria and arenaceous Foraminifera are mentioned in the preliminary report, but were not observed in the sample examined.

Minerals (traces); the few minerals of appreciable size have a mean diameter of $0.3 \mathrm{~mm}$., and are angular, but most of the particles are too small to be determined; the larger and more abundant particles are palagonite, while plagioclase (not identified) and magnetite are also present; the most characteristic mineral is phillipsite, of which there are a few, very small, isolated crystals; manganese oxide is diffused in particles of microscopic size; there are also a few flakes of some greenish chloritic mineral.

Fine Washings (66.98 per cent), chocolate-brown flocculent clay, with a few minute mineral particles.

No. 30. Station 4701, 26th December, 1904.

Lat. $19^{\circ} 11.5^{\prime} \mathrm{S}$.; long. $102^{\circ} 24^{\prime} \mathrm{W}_{\text {; }}$; depth, 2265 fathoms.

RED CLAY : dark chocolate-brown, plastic and sticky, forming when dried hard lumps that give a shining brown streak. 
THE DEPTH AND MARINE DEPOSITS OF THE PACIFIC OCEAN. 59

Calcium carbonate : 11.80 per cent, principally pelagic Foraminifera, many broken; with a good many Fishes' teeth, and a few bottom-living Foraminifera (Rotalia).

Residue: 88.20 per cent, mostly "fine washings," the larger washings from 12 grams of clay amounting to only a few centigrams :-

Siliceous Organisms (traces), very few Sponge spicules.

Minerals (traces); the rare particles present are angular, and only very few attain a diameter of $0.1 \mathrm{~mm}$. ; most of them belong to some decomposed basic mineral, and are present as greenish, nearly opaque, flakes ; plagioclase, augite, manganese grains, and phillipsite (in the form of isolated crystals, not in clusters) may be recognized.

Fine Washings (88.20 per cent), chocolate-brown flocculent clay, the dark color being due to numerous very minute grains of manganese; a few small crystals of phillipsite and other minute mineral particles observed.

No. 31. Station 4703,27 th December, 1904.

Lat. $17^{\circ} 18.6^{\prime}$ S. ; long. $100^{\circ} 52.3^{\prime} \mathrm{W}$.; depth, 2228 fathoms.

GLOBIGERINA OOZE: earthy-brown, plastic, but not sticky; the dried lumps are only slightly coherent; a few Foraminifera visible to the naked eye.

Calcium carbonate: 40.92 per cent, pelagic Foraminifera (mostly broken), Fishes' teeth, a few small Echinoid spines, and various bottom-living Foraminifera.

REsidue : 59.08 per cent :-

Siliceous Organisms (0 per cent).

Minerals (traces); the principal mineral is phillipsite in crystals, $0.03 \mathrm{~mm}$. in length, and always isolated; a few particles, angular and $0.06 \mathrm{~mm}$. in mean diameter, belonging to a decomposed mineral, are nearly opaque, brown, and have lost all birefringence; manganese grains are numerous, but very small.

Fine Washings (59.08 per cent), flocculent clay, colored brown by minute manganese grains, with a few very small mineral particles.

No. 32. Station 4705, 28th December, 1904.

Lat. $15^{\circ} 5.3^{\prime}$ S. ; long. $99^{\circ} 19^{\prime}$ W.; depth, 2031 fathoms.

GLOBIGERINA OOZE: light gray, in places yellowish, chalky.

Calcium carbonate: 78.62 per cent, a great variety of pelagic and 
bottom-living Foraminifera, with microscopic scales of calcite, doubtless due to the comminution of these shells, a few Echinoid spines, Ostracodes, fragments of Lamellibranchs and Pteropods.

Residue : 21.38 per cent, rich red-brown, very clayey :-

Siticeous Organisms (traces), spherical Radiolaria, Diatoms, and Sponge spicules.

Minerals (traces), a very few angular particles, $0.4 \mathrm{~mm}$. in diameter, belonging chiefly to a basic labradorite; pyrites is met with in individuals showing sometimes crystalline faces; there are also particles belonging to a decomposed ferro-magnesian mineral, greenish, and nearly opaque; augite cannot be identified with certainty.

Fine Washings (21.38 per cent), practically pure clay, brown and flocculent, with a very few mineral particles too small for identification, and fragments of siliceous organisms.

The following is a list of the species of Foraminifera observed in the deposit from this station:-

Biloculina depressa, d'Orb.

$$
\text { "sphcera, d'Orb. }
$$

Spiroloculina tenuis (Czjzek).

Miliolina venusta (Kar.).

" seminulum (Linu.).

" oblonga (Montag.).

Bathysiphon filiformis, Sars.

Rhizammina algaformis, Brady.

Reophax spiculifera, Brady.

"nodulosa, Brady.

Haplophragmium latidorsatum (Bornem.).

"6

66 globigeriniforme (P.\& J.).

" anceps, Brady. glomeratum, Brady.

Ammodiscus tenuis, Brady.

Trochammina pauciloculata, Brady.

$$
\text { "ringens, Brady. }
$$

Webbina clavata, J.\& P.

Verneuilina pygmaea (Egger).

Gaudryina pupoides, d'Orb.

Bulimina elegans, d'Orb.

" aculeata, d'Orb.

Virgulina subsquamosa, Egger.

" schreibersiana, Czjzek.

"s squamosa, d'Orb.

Bolivina punctata, d'Orb.

Pleurostomella alternans, Sehw. subnodosa, Rss.
Cassidulina subglobosa, Brady.

"6 crassa, d’Orb.

" parkeriana, Brady.

" bradyi, Norman.

Lagena longispina, Brady.

"6 alveolata, Brady.

" " $\quad$ var. substriata, Brady.

" torquata, Brady.

" fimbriata, Brady.

" marginate (W. \& B.).

"6 striatopunctata, P. \& J.

" feildeniana, Brady.

" striata (d'Orb.).

Lagena hexagona (IVill.).

" exsculpta, Brady.

" formosa, Schw.

"6 semistriata, Will.

Nodosaria roemeri (Neugeb.).

Uvigerina brunnensis, Kar.

" asperula, Czjzek.

" aculeata, d'Orb.

Globigerina conglobata, Brady.

" sacculifera, Brady.

" aquilateralis, Brady.

" inflata, d'Orb.

" mubra, d'Orb.

" dubia, Egger.

" digitata, Brady. 
Globigerina bulloides, d'Orb.

Orbulina universa, d'Orb.

" " var. triloba, Rss.

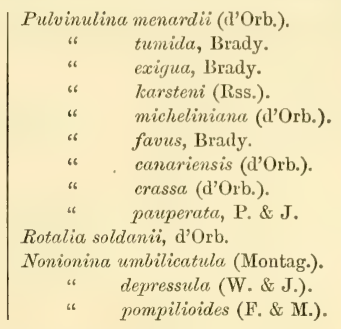

No. 33. Station 4707, 28th December, 1904.

Lat. $12^{\circ} 33.2^{\prime} \mathrm{S}$. ; long. $97^{\circ} 42^{\prime} \mathrm{W}$.; depth, 2120 fathoms.

GLOBIGERINA OOZE: olive-brown, plastic; reddish-gray and slightly coherent when dried.

Calcium carbonate: 71.01 per cent, principally pelagic Foraminifera, with a few bottom-living forms (Biloculina).

RESIDUE : 28.99 per cent, earthy brown :-

Siticeous Organisms (traces), spherical Radiolaria, Sponge spicules, and a few arenaceous Foraminifera.

Minerals (traces); the few particles present are angular, and have a mean diameter a little under $0.1 \mathrm{~mm}$.; plagioclase, augite, and manganese grains may be recognized, with particles of a decomposed ferro-magnesian mineral.

Fine Wastings (28.99 per cent), very flocculent, chocolate-brown clay (very easily attacked by hydrochloric acid, leaving a white residue), with a few fragments of minerals and siliceous organisms.

No. 34. Station 4709 , 30th December, 1904.

Lat. $10^{\circ} 15.2^{\prime} \mathrm{S}$; long. $95^{\circ} 40.8^{\prime} \mathrm{W}$.; depth, 2035 fathoms.

GLOBIGERINA OOZE: there are two samples, - one pure white and chalky, the other light gray, with a reddish tinge.

Calciun carbonate: 78.10 per cent. This percentage is the mean of analyses of the two samples, the white sample giving 81.20 per cent, and the gray sample 75.00 per cent; shells of pelagic Foraminifera and their comminuted fragments.

REsidue : 21.90 per cent, chocolate-brown in the case of the darker ooze, yellowish in the case of the white one. The residue is easily attacked by 
hydrochloric acid, the insoluble portion turning white, and manganese and iron passing into solution.

Siliceous Organisms (traces), spherical Radiolaria, Sponge spicules, and different species of arenaceous Foraminifera, all equally represented, and more abundant than the mineral particles.

Minerals (hardly any - the washing of 30 grams of substance amounts to no more than one or two centigrams). The very few particles are angular, and have a mean diameter of $0.15 \mathrm{~mm}$.; plagioclase, manganese grains, and hematite were observed.

Fine Washings (21.90 per cent), brown flocculent clay, with manganese grains, and fragments of siliceous organisms.

No. 35. Station 4711, 31st December, 1904.

Lat. $7^{\circ} 47.5^{\prime} \mathrm{S}$; ; long. $94^{\circ} 5.5^{\prime} \mathrm{W}$.; depth, 2240 fathoms.

GLOBIGERINA OOZE: brown, earthy, with little plasticity, containing Foraminifera visible to the naked eye.

Calcium carbonate : 54.54 per cent, principally pelagic Foraminifera, with a few bottom-living forms, and Fishes' teeth.

RESIDUE : 45.46 per cent, rich brown :-

Siliceous Organisms (traces), mostly Radiolaria, with a few Sponge spicules and arenaceous Foraminifera. Though Radiolaria, as individuals, are numerous, they would, if estimated by weight, amount to a very small fraction of 1 per cent.

Minerals (traces), manganese grains of various sizes (up to $2 \mathrm{~mm}$. in diameter), and small angular fragments of felspar, were observed.

Fine Washings (45.46 per cent), brown flocculent clay, with many fragments of siliceous organisms, and a few mineral particles too small to be identified, except manganese grains.

No. 36. Station 4713, 1st January, 1905.

Lat. $5^{\circ} 35.3^{\prime}$ S. ; long. $92^{\circ} 21.6^{\prime} \mathrm{W}$.; depth, 2191 fathoms.

GLOBIGERINA OOZE: according to the preliminary report there was a light-brown ooze at the top of the cylinder, and a light-gray ooze below, but only a small quantity of the two layers mixed was received; the ooze is somewhat plastic when wet, incoherent when dry.

Calcium carbonate : 54.54 per cent, many pelagic Foraminifera and a few Echinoid spines. 
Residue : 45.46 per cent, olive brown, slightly greenish :-

Siliceous Organisms (0.25 per cent approximately), spherical Radiolaria, Sponge spicules, and Diatoms.

Minerals (traces), only manganese grains were recognized in the small amount available for examination.

Fine Washings (45.21 per cent), greenish olive-brown in color when in a sufficiently thick layer; under the microscope light-gray clay, with many remains of siliceous organisms and a few mineral particles too small for identification, except manganese grains.

No. 37. Station 4715, 2nd January, 1905.

Lat. $2^{\circ} 40.4^{\prime} \mathrm{S}$.; long. $90^{\circ} 19.3^{\prime} \mathrm{W}$.; depth, 1743 fathoms.

GLOBIGERINA OOZE: light gray, nearly white, plastic when wet, chalky when dry; very little material.

Calcium CARBonate: 50 per cent, mostly pelagic Foraminifera, generally broken; a few bottom-living forms (Rotalidæ), one or two Echinoid spines.

Residue : 50 per cent:-

Siliceous Organisms (traces), Radiolaria, Diatoms, and Sponge spicules equally abundant; also one or two arenaceous Foraminifera.

Minerals (traces), one or two manganese grains, and probably a few fragments of augite, having a mean diameter of 0.01 to $0.02 \mathrm{~mm}$.

Fine Washings (about 50 per cent), light-brown, flocculent clay, with many fragments of siliceous organisms; a few extremely minute mineral particles.

No. 38. Station 4520 , 11 th January, 1905.

Lat. $1^{\circ} 46.8^{\prime} \mathrm{S}$. ; long. $91^{\circ} 36^{\prime} \mathrm{W}$.; depth, 1815 fathoms.

GLOBIGERINA OOZE : the material consists of two layers : one light gray, the other light brown, the brown one being more coherent when dried.

Calcium carbonate (the percentage of calcium carbonate was determined in both the gray and the brown ooze, and curiously enough was found to be absolutely the same in both cases, viz. : 45.50 per cent): many species of pelagic Foraminifera, mostly broken, with a good many Echinoid spines, a few Fishes' teeth, and bottom-living Foraminifera (Rotalidæ and Miliolidæ).

Residue : 54.50 per cent, rich brown :-

Siliceous Organisms (0.10 per cent approximately), Radiolaria, Diatoms, Sponge spicules, and arenaceous Foraminifera are equally abundant. 
Minerals (0.10 per cent approximately), angular, ranging from under 0.03 to $0.05 \mathrm{~mm}$. in diameter; augite, plagioclase (probably labradorite), magnetite, brownish volcanic glass are the most abundant, with a few manganese grains and particles of some chloritic mineral, greenish and crypto-crystalline.

Fine Washings (54.30 per cent), brown flocculent clay, with many fragments of siliceous organisms and minute mineral particles.

No. 39. Station 4521, * 11th January, 1905.

Lat. $2^{\circ} 14.3^{\prime} \mathrm{S}$. ; long. $92^{\circ} 29.9^{\prime} \mathrm{W}$.; depth, 1871 fathoms.

GLOBIGERINA OOZE: gray and plastic when wet; white, chalky, and coherent when dried.

Calcium carbonate : 45.01 per cent, principally pelagic Foraminifera, mostly broken shells, with many bottom-living forms (Rotalia), and a few Echinoid spines belonging to young individuals.

Residue : 54.99 per cent :-

Siliceous Organisms (traces); Radiolaria are the most abundant, Sponge spicules and Diatoms being poorly represented.

Minerals (very few), angular; mean diameter under $0.02 \mathrm{~mm}$; augite, with a few manganese grains and flakes of hematite, can alone be identified; the other particles are too small to be determined.

Fine Wastings (54.99 per cent), gray clay containing many fragments of siliceous organisms and minute mineral particles.

No. 40. Station 4522,* 11th January, 1905.

Lat. $2^{\circ} 42.4^{\prime}$ S.; long. $93^{\circ} 30^{\prime} \mathrm{W}$.; depth, 1924 fathoms.

GLOBIGERINA OOZE: light gray, plastic and slightly sticky; coherent with chalky appearance when dried.

Calcium carbonate: 55.90 per cent, shells of pelagic and bottom-living Foraminifera, and their comminuted fragments, and Echinoid spines.

Residue : 44.10 per cent :-

Siliceous organisms (traces), Radiolaria, Diatoms, and Sponge spicules.

Minerals (traces), angular; mean diameter $0.02 \mathrm{~mm}$; the most abundant is an olive-green, crypto-crystalline, chloritic mineral, with a few particles of augite, and one or two manganese grains.

Fine Washings (44.10 per cent), light-gray clay, slightly greenish, half its weight consisting of remains of siliceous organisms, with a few minute mineral particles. 
No. 41. Station $4523, *$ 12 th January, 1905.

Lat. $3^{\circ} 34^{\prime}$ S.; long. $95^{\circ} 35.4^{\prime}$ W. ; depth, 2031 fathoms.

GLOBIGERINA OOZE: white, with brownish spots, slightly plastic when wet; chalky and slightly coherent when dried.

Calcium carbonate: 55.90 per cent, pelagic Foraminifera, including many young individuals, a few bottom-living forms (Rotalidæ, Uvigerina), and small Echinoid spines.

RESIDUE : 44.10 per cent :-

Siliceous Organisms ( 0.5 per cent - the actual percentage is much higher, as many broken particles pass off with the "fine washings"), mostly well-preserved Radiolaria belonging to different species, with a few Sponge spicules, Diatoms, and arenaceous Foraminifera.

Minerals (traces); all that can be observed in the sample available for examination are a few insignificant particles of some reddish product of decomposition.

Fine Washings (43.60 per cent), light-gray flocculent matter, almost entirely formed of the remnants of siliceous organisms; there is very little actual clay, and the few mineral particles present are too small to be identified.

No. 42. Station 4717 , 13th January, 1905.

Lat. $5^{\circ} 10^{\prime} \mathrm{S}$. ; long. $98^{\circ} 56^{\prime} \mathrm{W}$; ; depth, 2153 fathoms.

Besides the sample from the sounding tube used for the following description, there is a fairly large quantity of material, which had apparently been trawled and subjected to a certain amount of washing; it is dark gray in color, yellowish on the top, and emits a faint smell of hydrogen sulphide, very pronounced on treatment with hydrochloric acid. Although this gray ooze fills man̉y of the broken shells there are no actual casts.

GLOBIGERINA OOZE: light red-brown, plastic, with many Foraminifera visible to the naked eye; when dried slightly coherent, the lumps breaking easily.

Calcium carbonate : 60.30 per cent; mostly pelagic Foraminifera, with a few bottom-living forms, Echinoid spines, teeth of Fish, and coccoliths.

Residue: 39.70 per cent :-

Siliceous Organisms (about 0.1 per cent), principally Radiolaria, arenaceous Foraminifera, and Diatoms, with a few Sponge spicules.

Minerals (traces), angular; menn diameter a little over $0.01 \mathrm{~mm}$. ; the 
mineral particles are too small to be accurately determined, with the exception of small particles of volcanic glass and plagioclase; the determination of what appears to be augite is doubtful.

Fine Washings (39.60 per cent), rich brown, very flocculent clay, containing many fragments of siliceous organisms, and a very few minute mineral particles.

The following is a list of the species of Foraminifera observed in the deposit from this station :-

Biloculina ringens (Lamk.).

" depressa, d'Orb.

" " var. serrata, Brady.

“ elongata, d'Orb.

Miliolina venusta (Kar.).

" oblonga (Montag.).

Bathysiphon filiformis, Sars.

Hyperammina ramosa, Brady.

Rhizammina algaformis, Brady.

Reophax distans, Brady.

" dentaliniformis, Brady.

Haplophragmium globigeriniforme (P. \& J.).

Hormosina globulifera, Brady.

Ammodiscus shoneanus, Sidd.

" charoides (J. \& P.).

Webbina clavata, J. \& P.

Gaudryina pupoides, d'Orb.

Clavulina communis, d'Orb.

Bulimina aculeata, d'Orb.

Virgulina schreibersiana, Czjzek.

"squamosa, d'Orb.

Pleurostomella brevis, Schw.

Cassidulina bradyi, Norman.

" lavigata, d'Orb.

"subglobosa, Brady.

Lagena acuta (Rss.).

“ alveolata, Brady.

" feildeniana, Brady.

" marginata (W. \& B.).

“ $\operatorname{sulcata}($ W. \& J.).

“ gracillima (Seg.).

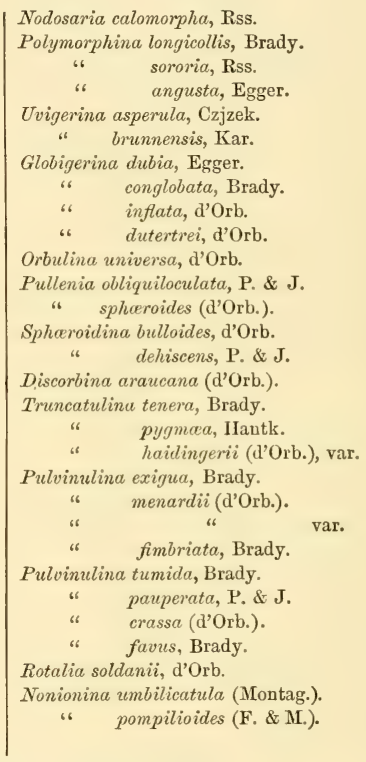

No. 43. Station 4719, 14th January, 1905.

Lat. $6^{\circ} 29.8^{\prime} \mathrm{S}$. ; long. $101^{\circ} 16.8^{\prime} \mathrm{W}$.; depth, 2285 fathoms.

RED CLAY: ${ }^{1}$ plastic and sticky, dark brown, but mottled with yellow patches; it contains no macroscopical elements; when dried, not so coher-

1 For Dr. Caspari's remarks on this deposit see Appendix, p. 167. 
ent as one would expect from its behavior in the moist state, the dry lumps crumbling easily between the fingers. An interesting point about this deposit is the remarkable facility with which it is attacked by cold dilute hydrochloric acid, which dissolves completely the oxides of iron, alumina, and manganese, and leaves a residue of silica. It is reported that the sounding-tube struck on a manganese nodule.

Calcium carbonate : 0 per cent.

Residue : 100 per cent :-

Siliceous Organisms, 0 per cent.

Minerals (traces); the very few mineral particles present could not be separated from the flocculent clay on account of their small size; they are angular, with a mean diameter of about $0.02 \mathrm{~mm}$.; augite is the only species recognized, and that not with certainty; minute manganese grains are distributed throughout the mass.

Fine Washings (100 per cent), flocculent clayey matter, with a few minute mineral particles.

No. 44. Station 4721, 15th January, 1905.

Lat. $8^{\circ} 7.5^{\prime}$ S. ; long. $104^{\circ} 10.5^{\prime}$ W.; depth, 2084 fathoms.

GLOBIGERINA OOZE: light brown, granular, with little plasticity when wet; practically incoherent when dried.

Calcium carbonate: 75 per cent, pelagic Foraminifera, with a very few bottom-living forms (Rotalidæ), and one or two small Echinoid spines.

REsidue : 25 per cent :-

Siliceous Organisms (about 0.1 per cent), Radiolaria, arenaceous Foraminifera, Sponge spicules, and Diatoms; in the coarser portion of the residue, siliceous organisms are much more abundant than mineral particles.

Minerals (traces), a few angular particles, $0.1 \mathrm{~mm}$. in mean diameter, including magnetite, augite, and a reddish product of decomposition.

Fine Washings (24.90 per cent), brown flocculent clay, with a good many fragments of siliceous organisms, but remarkably free from mineral particles, except minute manganese grains.

No. 45. Station 4726,18 th January, 1905.

Lat. $12^{\circ} 30.1^{\prime}$ S. ; long. $111^{\circ} 42.2^{\prime} \mathrm{W}$.; depth, 1700 fathoms.

GLOBIGERINA OOZE: dull brown, granular, very earthy, containing many conspicuous Foraminifera; neither plastic nor sticky; incoherent when dried. 
Calcium carbonate: 68.01 per cent, pelagic Foraminifera, with a few bottom-living forms (Rotalidæ); the more porous shells are colored light brown by limonite.

RESIDUE : 31.99 per cent; the residue consists essentially of "fine washings," nothing being left after careful decantation.

Siliceous Organisms, 0 per cent.

Minerals, 0 per cent.

Fine Washings (31.99 per cent), brown clay, remarkably rich in minute manganese grains and earthy limonite, with a very few remains of siliceous organisms (Diatoms and Sponge spicules), and mineral particles much too minute for identification.

No. 46. Station 4736, 23rd January, 1905.

Lat. $19^{\circ} 0.4^{\prime} \mathrm{S}$; l long. $125^{\circ} 5.4^{\prime} \mathrm{W}$.; depth, 2289 fathoms.

GLOBIGERINA OOZE: dark chocolate-brown, plastic and sticky in the wet state, but not very coherent when dried.

Calcium CARBonate: 50 per cent, pelagic Foraminifera, with a few bottom-living forms (Rotalidæ) and a good many Fishes' teeth.

REsidue : 50 per cent :-

Siliceous Organisms (traces), a very few Sponge spicules and Radiolaria.

Minerals (traces), angular; mean diameter $0.1 \mathrm{~mm}$. ; augite, plagioclase, magnetite, and a reddish product of decomposition, with a good many small, well-formed, elongated crystals of phillipsite with pyramidal terminal faces, and a few manganese grains.

Fine Washings (50 per cent), chocolate-brown clay, the brown color being due to manganese oxide, with a few mineral particles and remnants of siliceous organisms.

No. 47. Station $4525,{ }^{*} 25$ th January, 1905.

Lat. $21^{\circ} 36.1^{\prime}$ S. ; long. $131^{\circ} 35.3^{\prime} \mathrm{W}$.; depth, 2123 fathoms.

GLOBIGERINA OOZE: dark brown, with yellow patches, plastic when wet; forms when dried hard lumps crumbling under the action of water.

Calcium carbonate : 65.90 per cent, pelagic Foraminifera, with a few bottom-living forms (Rotalida).

REsidue : 34.10 per cent :-

Siliceous Organisms (small traces), very few Sponge spicules and Radiolaria. 
Minerals (traces), angular; mean diameter $0.1 \mathrm{~mm}$. f felspar, a little augite, magnetite, phillipsite, and manganese grains.

Fine Washings (34.10 per cent), chocolate-brown clay, with microscopic manganese grains and many minute crystals of phillipsite.

No. 48. Station 4739, 26th January, 1905.

Lat. $22^{\circ} 11.1^{\prime}$ S. ; long. $133^{\circ} 21^{\prime} \mathrm{W}$.; depth, 2042 fathoms.

GLOBIGERINA OOZE: light brown, earthy in texture, incoherent when dried; many Foraminifera visible to the naked eye.

Calcium carbonate: 58.62 per cent, pelagic Foraminifera, with a few bottom-living forms (Rotalida).

Residue : 41.38 per cent:-

Siliceous Organisms (traces), arenaceous Foraminifera, Sponge spicules, Radiolaria.

Minerals ( 0.75 per cent) ; two kinds of particles are present- (1) actual mineral particles, $0.1 \mathrm{~mm}$. in mean diameter, angular and rounded, felspar, augite, olivine, volcanic glass (always angular), a good many small yellow crystals of phillipsite $(0.01 \mathrm{~mm}$. by $0.03 \mathrm{~mm}$.), and a few particles of hematite; and (2) reddish, shapeless, highly magnetic particles, nearly $1 \mathrm{~mm}$. in diameter, doubtless formed of magnetite, the surface of which is oxidized, and making up about one-third of the minerals; there are also a few manganese grains, some exceeding $2 \mathrm{~mm}$. in diameter, and a good many cosmic spherules, with a mean diameter less than $0.1 \mathrm{~mm}$.

Fine Washings (40.63 per cent), flocculent clay, colored dark brown by numerous minute manganese grains, with other very small mineral particles, including phillipsite.

No. 49. Station $4526,{ }^{*} 27$ th January, 1905.

11 miles N. E. of Mt. Duff, Manga Reva; depth, 2070 fathoms.

GLOBIGERINA OOZE: light brown, with yellowish tinge, not sticky, hardly plastic; the dried lumps crumble under the action of water.

Calcium carbonate: 75 per cent, pelagic Foraminifera, including many small shells, with a few bottom-living forms (Rotalidæ and Biloculina depressa).

Residue : 25 per cent, dark brown :-

Siliceous Organisms (traces), only one or two arenaceous Foraminifera. Minerals (0.25 per cent), angular; mean diameter $0.3 \mathrm{~mm}$; plagio- 
clase, augite, olivine (?), volcanic glass, a little magnetite, a few manganese grains, and one or two flakes of hematite.

Fine Washings (24.75 per cent), very flocculent brown clay, with numerous but extremely minute mineral particles.

No. 50. Station 4531,* 6th February, 1905.

Lat. $21^{\circ} 4.5^{\prime} \mathrm{S}$. ; long. $133^{\circ} 1.2^{\prime} \mathrm{W}$.; depth, 2225 fathoms.

CALCAREOUS MUD : light brown, slightly coherent, powdery, containing no macroscopic elements.

Calcium carbonate: 72.72 per cent, many very minute coccoliths and Tunicate spicules, together with a large quantity of calcium carbonate, probably of organic origin, but so finely comminuted that no structure can be recognized under the microscope.

RESIDUE : 27.28 per cent :-

Siliceous Organisms, 0 per cent.

Minerals ( 0.1 per cent), principally manganese grains somewhat under $0.1 \mathrm{~mm}$. in diameter; most of the other particles are microscopic, a few attaining a diameter of $0.1 \mathrm{~mm}$. ; the only one that can be specifically determined is phillipsite, in the form of clusters; one or two particles appear to be volcanic glass.

Fine Washings (27.18 per cent), brown clay, darker in hue than the deposit itself, colored by the oxides of iron and manganese; no siliceous organisms can be seen, and the very rare mineral particles present are much too small to be determined.

No. 51. Station $4532,{ }^{*} 7$ th February, 1905.

Lat. $18^{\circ} 29.4^{\prime}$ S. ; long. $130^{\circ} 50.8^{\prime}$ W.; depth, 2319 fathoms.

RED CLAY : very dark brown, nearly black, very plastic and sticky, soft and clayey to the touch.

Calcium carbonate: 18 per cent, pelagic and bottom-living Foraminifera, and Fishes' teeth.

Residue : 82 per cent :-

Siticeous Organisms (small traces), only a few fragmentary arenaceous Foraminifera and Sponge spicules.

Minerals (small traces), principally manganese grains, $0.1 \mathrm{~mm}$. in diameter, a few angular splinters of colorless glass, and phillipsite in isolated crystals and twins. 
THE DEPTH AND MARINE DEPOSITS OF THE PACIFIC OCEAN. 71

Fine Washings (82 per cent), dark-brown flocculent clay, characterized by a great abundance of minute crystals of phillipsite, with one or two minute manganese grains.

No. 52. Station 4534, ${ }^{*}$ th February, 1905.

Lat. $13^{\circ} 51^{\prime}$ S. ; long. $126^{\circ} 53.5^{\prime} \mathrm{W}$.; depth, 2185 fathoms.

GLOBIGERINA OOZE : light brown, slightly coherent, not sticky.

Calcium carbonate: 72.72 per cent, pelagic Foraminifera, with a few bottom-living forms (Rotalia).

REsidue: 27.28 per cent; no clastic minerals nor siliceous organisms observed; the residue consists, of chocolate-brown flocculent clayey matter, containing numerous very small crystals of phillipsite and a few minute manganese grains.

No. 53. Station 4535, 10 th February, 1905.

Lat. $11^{\circ} 20^{\prime}$ S. ; long. $125^{\circ} 1.3^{\prime} \mathrm{W}$.; depth, 2215 fathoms.

GLOBIGERINA OOZE : light brown, slightly coherent when dried.

Calcium Carbonate : 77.26 per cent, pelagic Foraminifera, many of the shells being more or less fragmentary.

Residue: 22.74 per cent:-

Siliceous Organisms (traces), fragments of arenaceous Foraminifera and of Radiolaria, with Diatoms, and a few Sponge spicules.

Minerals (traces), one or two manganese grains only.

Fine Washings (22.74 per cent), brown flocculent clay, containing many minute manganese grains and other mineral particles much too small to be identified, and fragments of siliceous organisms.

No. 54. Station 4740, 11th February, 1905.

Lat. $9^{\circ} 2.1^{\prime} \mathrm{S}$; ; long. $123^{\circ} 20.1^{\prime} \mathrm{W}$.; depth, 2422 fathoms.

GLOBIGERINA OOZE: light brown, slightly coherent.

Calcium carbonate: 65 per cent, pelagic Foraminifera and their fragments, with a few bottom-living forms (Rotalidæ).

REsidue: 35 per cent, dark brown:-

Siticeous Organisms ( 0.25 per cent), Radiolaria, Diatoms, Sponge spicules, and arenaceous Foraminifera.

Minerals ( 0.25 per cent), very much decomposed, yellow, palagonitic 
substance, accompanied by a fer manganese grains and one or two clusters of phillipsite.

Füe Washings ( 34.50 per cent), rery flocculent, brown, clayej matter, with many siliceous remains, and minute manganese grains.

No. 55. Station 45.57, 13 th February, 1905.

Lat. $4^{\circ} 50.5^{\prime} \mathrm{S}$; long. $120^{\circ} 45.7^{\prime} \mathrm{W}$; d depth. 2350 fathoms.

GLOBIGERINA OOZE: light gray, incoterent. many of the Foraminifera being risible to the naked ese; rery little material arailable.

Cutcrcm CARBorate: 79 per cent, pelagic Foraminifera and their fragments, with a few bottom-living forms (Rotalidæ).

ResIDCE: 21 per cent : -

Siticeons Organisms (traces), Radiolaria, Diatoms, and Sponge spicules.

Minerale (traces), many small manganese grains.

Fine Washings (21 per cent), brown clas, rers flocculent, with fragments of siliceous organ:-ms acd minute manganese grains; other mineral particles much too small for identification.

\o. 56. Station 4538 , 14 th February, 1905.

Iat. $2^{\circ} 14^{\prime} \mathrm{S}$; ; long. $118^{\circ} 55.1^{\prime}$ W. ; depth, 2291 fathoms.

GLOBIGERINA OOZE: light gmy, chally, and incoherent, fne-grained.

Cilcitar capbosate: 65.90 per cent, pelagic Foraminifera, many of the s.tils zure or less fragmentary, with a few bottom-liring forms (Rotalidæ), and one or two Echinoid spines.

RissIDEE : $3 \pm .10$ per cent : -

Silicosus Organisms (traces), Diatoms, fragments of Radiolaria, and Sponge spicules.

Menerale, 0 per cent.

Fine Washings (34.10 per cent), light reddish-brown clajey matter, with remains of siliceous organisms, and a fem very small mineral particles.

No. 57. Station $47 \pm 2,15$ th February, 1905.

Lat. $0^{\circ} 3.4^{\prime} \mathrm{X}$.; long. $117^{\circ} 15.8^{\prime} \mathrm{W}$; depth, 2320 fathoms.

GLDBIGERIA OOZE: ligho gray, neariy white, Ane-grained, and of low specific grariț when dried.

Carcitur CApBosate: 63.62 per cent, pelagic Foraminifera and their comminuted fragments. The trawl brought up some curious calcareous 
organisms, apparently calcareous Sponges, in the shape of flat slabs formed by the agglomeration of twelve-pointed spicules, but easily crumbling under pressure; the spicules are all joined to each other, so that there is very little space between them, the whole body being thus rather compact, though not strong.

RESIDUE : 36.38 per cent :-

Siticeous Organims (traces), a few large Padiolaria and Diatoms remain in the coarser part of the residue, but most of the siliceous remains pass off with the "fine washings," of which they constitute a large part.

Minerals ( 0.20 per cent), angular, varying from 0.01 to $0.10 \mathrm{~mm}$. in diameter; felspar, manganese grains, brown decomposed particles, apparently decomposed augite, and a few volcanic glass fragments.

Fine Washings (36.18 per cent), light-brown clay, with many fragments of siliceous organisms, and minute mineral particles.

No. 58. Station $4540,{ }^{*} 17$ th February, 1905 .

Lat. $3^{\circ} 25.6^{\prime} \mathrm{N}$; ; long. $115^{\circ} 54^{\prime} \mathrm{W}$.; depth, 2200 fathoms.

GLOBIGERINA OOZE : light bromn, incoherent, gray with a reddish tinge when dried.

Calcius carboyate: 69 per cent, pelagic Foraminifera, with a few bottom-liring forms (Rotalidæ), and small Echinoid spines.

REsidue : 31 per cent :-

Siliceous Organisms (0.10 per cent), Radiolaria, Diatoms, and Sponge spicules ; many siliceous remains pass off with the "fine washings," of which they make up perhaps one-half the volume.

Ninerals (traces); a few particles of magnetite and limonite were observed.

Fine Washings (30.90 per cent), flocculent, brown, clayey matter, with many fragments of siliceous organisms, and a few mineral particles too minute for identification.

No. 59. Station $45 \pm 1, *$ 18th February, 1905.

Lat. $4^{\circ} 55^{\prime} \mathrm{N}$. ; long. $112^{\circ} 2 \bar{\tau}^{\prime} \mathrm{W}$.; depth, $217 \pm$ fathoms.

GLOBIGERIIA OOZE: dark gray, slightly reddish, rather stickr, but incoherent when dried; the Foraminifera shells are not quite fresh. being generally impregnated with clayey matter. 
Calcium carbonate: 68.18 per cent, pelagic Foraminifera, mostly broken, with a few Echinoid spines.

RESIDUE : 31.82 per cent; there is too little material to determine the percentages of minerals and siliceous organisms.

Siliceous Organisms form a large part of the "fine washings," and are represented by Diatoms, broken Radiolaria, and Sponge spicules.

Minerals; most of the mineral particles pass off with the "fine washings," and include silicates too small for identification, and manganese grains.

Fine Washings, brown, flocculent, clayey matter, colored by the oxides of manganese and iron, with fragments of minerals and siliceous organisms.

No. 60. Station 4544, * 21st February, 1905.

Lat. $10^{\circ} 38^{\prime} \mathrm{N}$.; long. $106^{\circ} 47.6^{\prime} \mathrm{W}$.; depth, 1955 fathoms.

RED CLAY : sticky chocolate-brown clay, containing not a trace of calcium carbonate. A very small quantity of material available for examination.

Calcium carbonate ( 0 per cent).

Residue (100 per cent) :- -

Siliceous Organisms (traces), a very few Sponge spicules.

Minerals (about 1 per cent); the only mineral of appreciable size is manganese in the form of grains $0.10 \mathrm{~mm}$. in mean diameter; other minerals belonging to silicates are present, but are very minute and pass off with the "fine washings."

Fine Washings (about 99 per cent), brown flocculent clay, containing a few minute mineral particles and siliceous remains.

Note. - This sample is peculiar for such a depth, suggesting that the calcium carbonate has by some means been removed.

Appended are brief descriptions of a few samples which do not apparently represent the actual deposit at the bottom, followed by a few notes on the unlabelled samples :-

\section{WAShed SAMPles.}

Station 4611, 18th October, 1904.

Lat. $10^{\circ} 33^{\prime} \mathrm{N}$. ; long. $88^{\circ} 30^{\prime} \mathrm{W}$.; depth, 1792 fathoms.

GLOBIGERINA OOZE: the deposit is not in its original state, and must have been subjected to washing during the process of collection; it is quite incoherent and granular, and essentially composed of Foraminifera, pelagic and 
THE DEPTH AND MARINE DEPOSITS OF THE PACIFIC OCEAN. 75

bottom-living, but mostly pelagic: Globigerina and Pulvinulina; these shells are all colored reddish-brown by oxide of iron. As the clayey matter has disappeared, an estimation of the carbonate of calcium would have been useless.

Minerals (traces), angular; mean diameter $0.02 \mathrm{~mm}$., quartz and magnetite are present in equal quantities; one or two greenish particles may be attributed to a member of the chlorite family.

Siliceous Organisms; Sponge spicules are the only true siliceous organisms ; there are also a good many yellowish and brown imperfect casts of Foraminifera.

Station 4642, 7th November, 1904.

Lat. $1^{\circ} 30.5^{\prime} \mathrm{S}$. ; long. $89^{\circ} 35^{\prime} \mathrm{W}$.; depth, 300 fathoms.

CALCAREOUS SAND : very little material,-incoherent sand, formed of fragments (mean diameter, $2 \mathrm{~mm}$.) of Lamellibranch and Gasteropod shells, accompanied by fragments of Corals, and entire specimens of surface and bottom-living Foraminifera, together with young individuals of Gasteropoda.

Very few minerals are present; plagioclase, augite, a red product of the decomposition of some ferruginous mineral, and a little magnetite.

Station 4693, 14th December, 1904.

Lat. $26^{\circ} 30.1^{\prime} \mathrm{S}$. ; long. $105^{\circ} 45.2^{\prime} \mathrm{W}$.; depth, 1142 fathoms.

GLOBIGERINA OOZE: gray, granular, incoherent, with many irregular fragments of manganese nodules; some of the Foraminifera (especially Orbulina universa) are visible to the naked eye.

A few Sponge spicules and arenaceous Foraminifera were observed.

Many fragments of pumice and other volcanic rocks, and fragments of manganese nodules, are present; the mineral particles observed are angular, with a mean diameter of $0.3 \mathrm{~mm}$.; augite, plagioclase, green chlorite, with minute splinters of volcanic glass, also a brown opaque ferruginous product of the decomposition of some basic mineral, and a little magnetite.

Station 4723, 16th January, 1905.

Lat. $10^{\circ} 14.3^{\prime} \mathrm{S}$; ; long. $107^{\circ} 45.5^{\prime} \mathrm{W}$.; depth not mentioned.

GLOBIGERINA OOZE: the material is very granular and incoherent; principally pelagic Foraminifera, with many small individuals; a few bottomliving forms (Rotalidæ), a few Sponge spicules and Radiolaria; and a few manganese grains, 0.1 to $0.5 \mathrm{~mm}$. in diameter, angular fragments of augite, and one or two splinters of volcanic glass. 
Station 4728, 19th January, 1905.

Lat. $13^{\circ} 47.5^{\prime}$ S. ; long. $114^{\circ} 21.6^{\prime} \mathrm{W}$.; depth, 1055 fathoms.

GLOBIGERINA OOZE: the material is almost entirely made up of the shells of pelagic Foraminifera and their fragments, with one or two very small Echinoid spines; a very few Sponge spicules, one or two Radiolaria and Diatoms; and a few angular fragments ( $\frac{1}{4}$ to $\frac{3}{4}$ inch in diameter) of a black basalt, containing abundant glassy base, and showing hardly any weathering.

Station 4732, 21st January, 1905.

Lat. $16^{\circ} 32.5^{\prime}$ S. ; long. $119^{\circ} 59^{\prime} \mathrm{W}$.; depth, 2012 fathoms.

GLOBIGERINA OOZE: the material is light gray, with a slight reddish tinge when dried, granular and incoherent, and consists almost entirely of pelagic Foraminifera and their comminuted fragments, with a few coccoliths and rhabdoliths; a few remains of Radiolaria and Sponge spicules; and a little chestnut-brown flocculent clayey matter.

Station 4737, 24th January, 1905.

Lat. $19^{\circ} 57.5^{\prime} \mathrm{S}$; ; long. $127^{\circ} 20.3^{\prime} \mathrm{W}$; ; depth, 2060 fathoms.

GLOBIGERINA OOZE: there is a very little washed material sticking to the sides of the bottle, consisting chiefly of pelagic Foraminifera, with a few bottom-living forms (Rotalidæ and Miliolidæ); a few angular fragments of felspar were observed.

\section{Unlabelled Samples.}

As already stated, twenty-nine of the bottles were unlabelled, and upon examination the contents were found to be as follows:-
9, Globigerina Ooze,
2, Red Clay,
2, Radiolarian Ooze,
8, Blue Mud,
4, Green Sand,
1, Green Mud,
1, Voleanic Mud,
2, Incoherent material.

A. GLOBIGERINA OOZE. The Globigerina Ooze in three of the bottles was found on examination to be similar in composition, and it is possible all may have come from the same station. The percentage of calcium carbonate is about 60 or 70 , and the siliceous organisms make up about 10 per cent.

Another sample, in which most of the Foraminifera shells are broken, approaches the border-line of Radiolarian Ooze, since the residue is almost entirely made up of Radiolaria.

Another sample was found, upon analysis to contain 38.91 per cent of 
calcium carbonate; otherwise it might equally well have been called a Diatom Ooze or a Radiolarian Ooze, so abundant were these siliceous remains.

Another sample was incoherent and finely granular, as though it had been subjected to a certain amount of washing; the residue consists principally of Sponge spicules with glauconitic casts and a few Diatoms.

Another sample is apparently from deep water, as many of the shells are broken. It is mottled light and dark brown, while the residue is chocolate brown from the large proportion of manganese grains. The percentage of calcium carbonate is 70 or 80 , and there are many Radiolaria and Diatoms probably equal to 5 per cent.

The shreds of a label were found in another bottle, and the number 4638 could with difficulty be made out. According to the preliminary report, Station 4638 is in Lat. $0^{\circ} 27^{\prime}$ N.; long. $87^{\circ} 13^{\prime}$ W.; and the depth is 1450 fathoms. The deposit contains 61.51 per cent of calcium carbonate, and is mottled dark and light gray; many of the Foraminifera shells are broken, and discolored by manganese.

Another sample which was analyzed gave 53.76 per cent of calcium carbonate, though in the bottle it had the appearance of a Red Clay; and the residue is of a chocolate color.

B. RED CLAY. One sample contained much manganese in the form of small nodules and grains, with a few decomposed volcanic rock fragments, and a few Radiolaria and Diatoms; no calcium carbonate.

Another sample also contained no calcium carbonate, and a few volcanic mineral particles and one or two Radiolaria filled with clay were observed. Shreds of a label were extracted from this bottle on which, after the word "depth," the figures 26 - were deciphered, so that it seems not unlikely that the material came from Station 4511 (Lat. $15^{\circ} 39^{\prime}$ S.; long. $83^{\circ} 27.4^{\prime}$ W. ; depth, 2620 fathoms).

C. RADIOLARIAN OOZE. One sample of Radiolarian Ooze contained about 5 per cent of calcium carbonate (consisting principally of pelagic Foraminifera), and probably less than 5 per cent of mineral particles (volcanic glass and manganese grains). The skeletons of Radiolaria appear to make up probably about one-half of this deposit.

Another sample contained no calcium carbonate; the ooze is of a pale green color, and besides the Radiolaria, Diatoms are also very abundant, while mineral particles are few and small. 
D. BLUE MUD. The samples of Blue Mud were all of a greenish color, except one which had undergone decomposition in the bottle, and had turned black with a thin layer of a gray color on the top. The percentage of calcium carbonate varied from 0 to about 5 , while one sample, apparently approaching the border-line of Globigerina Ooze, gave on analysis 15.15 per cent. The siliceous organisms ranged from 1 to 5 per cent, principally Diatoms, with Sponge spicules, Radiolaria, and arenaceous Foraminifera. In one sample the Diatoms were impregnated with sulphide of iron in the form of minute spherules. The minerals made up from 10 to 40 per cent, the quartz grains in one sample attaining a diameter of $0.6 \mathrm{~mm}$., and in another $0.4 \mathrm{~mm}$; ; besides quartz, mica, felspar, and hornblende were noted. One sample contained rock fragments ranging up to 3 inches in diameter, a rolled pebble, worm-eaten twigs, worm-tubes (Onuphis, one very large), fragments of bone, and hardened blocks of deposit, associated with a little of the mud in which the other items enumerated were apparently embedded.

E. GREEN SAND. The four samples of Green Sand may possibly have all come from the same station. Though the percentage of calcium carbonate seemed to vary somewhat (one sample analyzed gave 13.24 per cent, while another seemed to contain about 25 per cent), one-half of the individual samples was apparently made up of glauconite grains and glauconitic casts, representing, indeed, one of the purest green sands ever submitted to us for examination. Quartz and mica, and a few siliceous organisms (Sponge spicules, Diatoms, and Radiolaria) were also noted.

F. GREEN MUD. The sample of Green Mud has undergone decomposition in the bottle, for the lower portion is much darker green than the upper portion. Analysis gave 61.63 per cent of calcium carbonate, made up principally of pelagic and bottom-living Foraminifera, while many Radiolaria, with a few Diatoms and Sponge spicules, were noted, in addition to glauconitic. casts and glauconite grains and other minerals.

G. VOLCANIC MUD. The sample, though containing about 20 per cent of calcium carbonate (pelagic Foraminifera with coccoliths and many rhabdoliths), is principally made up of volcanic material, the particles colored black, brown, and yellow, and having the appearance of volcanic ash.

H. INCOHERENT MATERIAL. One sample consists principally of manganese nodules, embedded in a deposit that might be called a Radiolarian ooze. 
THE DEPTH AND MARINE DEPOSITS OF THE PACIFIC OCEAN. 79

It contains no calcium carbonate, and besides the siliceous organisms and manganese grains, only a few minerals were observed in the clayey matter.

Another sample consists of : (1) a small piece of volcanic rock in process of transformation into palagonite, (2) a flat piece of palagonite much impregnated with manganese, and (3) a small manganese nodule. 


\section{BOTTOM SAMPLES COLLECTED DURING THE THIRD EXPE- DITION OF DR. ALEXANDER AGASSIZ, 1899-1900.}

The bottom deposits collected by the "Albatross" during her 1899-1900 cruise were received at the Challenger Office shortly after the return of the expedition, and were examined by Sir John Murray, Mr. James Chumley, and Mr. Robert Dykes. Dr. Alexander Agassiz published some remarks on the bottom deposits by Sir John Murray in the preliminary report already cited. Most of the mineralogical determinations have recently been revised by Dr. G. W. Lee, who has also examined the manganese nodules collected during this cruise, which were not forwarded to the Challenger Office till some considerable time after the deposit-samples. Dr. W. A. Caspari has made a detailed study in the Challenger Office laboratory of the white palagonitic tuff from Station 2, and his results will be found in an appendix to this Report.

The number of samples received from this cruise was 237, but, unfortunately, as many as 160 of these could not be fully described owing to the fact that in 97 cases the material had evidently been subjected to a certain amount of washing before reaching our hands, and in 53 other instances the amount of material avirilable was too small to allow of a definite analysis being made. In 9 cases the material consisted of manganese nodules or rock fragments without any true deposit, and in one case the bottle in which the sample was contained was without any label or number, and the description of the material is, therefore, less important than it might otherwise have been. From these various causes the number of samples fully described in the following pages is reduced to 77 . These are distributed in depth as follows :-

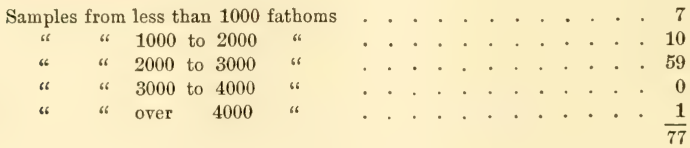


THE DEPTH AND MARINE DEPOSITS OF THE PACIFIC OCEAN. 81

The types of deposit to which these 77 samples are referred are as follows:-

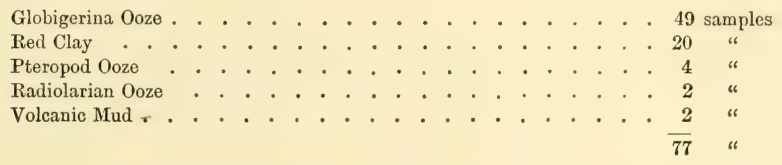

Detailed Descriptions of the Deposit-Samples.

(Numbered consecutively as collected.)

No. 1. Station 2, 27th August, 1899.

Lat. $28^{\circ} 23^{\prime} \mathrm{N}$. ; long. $126^{\circ} 57^{\prime}$ W. ; depth, 2368 fathoms.

RED CLAY: brown, with lighter-colored patches, but appears uniform in composition; contains a few small manganese nodules.

Calcium carbonate: 1 per cent, a few coccoliths.

Residue : 99 per cent, brown :-

Siliceous Organisms (1 per cent), represented by fragments of Radiolaria.

Minerals (small traces), mean diameter $0.06 \mathrm{~mm}$.; the most abundant mineral is felspar, represented by orthoclase and plagioclases having the optical properties of andesine and labradorite. A more acid plagioclase appears to be present, but its exact nature could not be determined. Volcanic glass (one splinter $2 \mathrm{~mm}$. long), augite (very rare), probably hornblende undergoing decomposition, manganese grains, red palagonite, and small lumps of a whitish opaque substance were also observed. Mineral particles are here extremely rare, only a few having been obtained from the washing of a large quantity of material.

Fine Washings (98 per cent), amorphous clayey matter.

Besides a good supply of the Red Clay, many manganese nodules and slabs of palagonitic tuff described in the sequel, the "Albatross" obtained at this station some rock fragments, determined by Dr. Teall, H. M. Geological Survey, as : -

(1) hornblende-andesite,

(2) serpentine,

(3) fine grained sandstone,

(4) black chert. ${ }^{1}$

1 See Mem. Mus. Comp. Zoöl., Vol. XXVI., No. 1, p. 71, 1902. 
No. 2. Station 4, 29th August, 1899.

Lat. $24^{\circ} 45^{\prime}$ N.; long. $130^{\circ} 16^{\prime} \mathrm{W}$.; depth, 2628 fathoms.

RED CLAY : brown.

Calcium carbonate: 2.05 per cent, only a few small Fishes' teeth observed.

Residue: 97.95 per cent, brown :-

Siliceous Organisms (1 per cent), Sponge spicules.

Minerals ( 1 per cent), mean diameter $0.06 \mathrm{~mm}$., angular, felspar, decomposed ferro-magnesian minerals, one or two crystals of phillipsite, magnetite.

Fine Washings (95.95 per cent), amorphous clayey matter, with minute minerals, etc.

No. 3. Station 5, 30th August, 1899.

Lat. $22^{\circ} 42^{\prime} \mathrm{N}$. ; long. $131^{\circ} 54^{\prime} \mathrm{W}$. ; depth, 2740 fathoms.

RED CLAY : brown.

Calcium carbonate: 1 per cent, only a few Fish teeth observed.

Residue: 99 per cent, brown :-

Siliceous Organisms (2 per cent), Radiolaria, Sponge spicules, arenaceous Foraminifera.

Minerals (1 per cent), mean diameter $0.08 \mathrm{~mm}$., angular, felspar, glassy particles, magnetite, and manganese grains.

Fine Washings (96 per cent), amorphous clayey matter, minute minerals, etc.

No. 4. Station 6, 31st August, 1899.

Lat. $20^{\circ} 26^{\prime} \mathrm{N}$. ; long. $133^{\circ} 28^{\prime} \mathrm{W}$.; depth, 2810 fathoms.

RED CLAY : brown.

Calcium carbonate : 1 per cent, a few teeth of Fishes.

Residue : 99 per cent, brown :-

Siliceous Organisms (1 per cent), Sponge spicules, Radiolaria, arenaceous Foraminifera.

Minerals ( 1 per cent), mostly angular, mean diameter $0.12 \mathrm{~mm}$. (one grain of felspar $0.8 \mathrm{~mm}$. in diameter observed), felspar (orthoclase), glassy particles, augite, magnetite, manganese grains.

Fine Washings (97 per cent), amorphous clayey matter, with minute mineral particles, etc. 
THE DEPTH AND MARINE DEPOSITS OF THE PACIFIC OCEAN. 83

No. 5. Station 7, 1st September, 1899.

Lat. $18^{\circ} 19^{\prime}$ N. ; long. $134^{\circ} 57^{\prime}$ W. ; depth, 2881 fathoms.

RED CLAY : light brown, with darker patches.

Calcium carbonate: 1.05 per cent, a few teeth of Fishes.

Residue : 98.95 .per cent, brown:-

Siliceous Organisms (1 per cent), Sponge spicules, Radiolaria, arenaceous Foraminifera.

Minerals (1 per cent), mostly angular, mean diameter $0.1 \mathrm{~mm}$., felspar, glassy particles, grains of manganese, and magnetite.

Fine Washings (96.95 per cent), amorphous clayey matter, with minute mineral particles, etc.

No. 6. Station 11, 3rd September, 1899.

Lat. $14^{\circ} 38^{\prime} \mathrm{N}$. ; long. $136^{\circ} 44^{\prime} \mathrm{W}$.; depth, 2646 fathoms.

RED CLAY : dark brown, mottled with lighter-colored patches.

Calcium carbonate: 1 per cent, teeth of Fishes.

Residue: 99 per cent, brown :-

Siliceous Organisms (2 per cent), Radiolaria, Sponge spicules, arenaceous Foraminifera, Diatoms.

Minerals (1 per cent), angular, mean diameter $0.08 \mathrm{~mm}$., felspar, glassy particles, augite, magnetite, grains of manganese, phillipsite.

Fine Washings (96 per cent), amorphous clayey matter, with minute mineral particles and fragments of siliceous organisms.

No. 7. Station 12, 4th September, 1899.

Lat. $12^{\circ} 7^{\prime} \mathrm{N}$.; long. $137^{\circ} 18^{\prime} \mathrm{W}$.; depth, 2883 fathoms.

RADIOLARIAN OOZE : light brown.

Calcium carbonate: 1 per cent, Fishes' teeth.

Residue : 99 per cent, brown :-

Siliceous Organisms (30 per cent), Radiolaria, Sponge spicules, Diatoms.

Minerals (2 per cent), angular, mean diameter $0.1 \mathrm{~mm}$., glassy particles, felspar, hornblende.

Fine Washings (67 per cent), amorphous clayey matter, with minute mineral particles and fragments of siliceous organisms. 
No. 8. Station 13, 5th September, 1899.

Lat. $9^{\circ} 57^{\prime} \mathrm{N}$. ; long. $137^{\circ} 47^{\prime} \mathrm{W}$.; depth, 2690 fathoms.

RADIOLARIAN OOZE: light brown, with lighter spots and patches.

Calcium carbonate: 1 per cent, Fishes' teeth.

Residue: 99 per cent, light brown:-

Siliceous Organisms (40 per cent), Radiolaria, Sponge spicules, Diatoms.

Minerals (3 per cent), angular, mean diameter $0.12 \mathrm{~mm}$., obsidian, manganese grains, sanidine (?), and decomposed ferro-magnesian minerals.

Fine Washings (56 per cent), clayey matter, with many splinters of siliceous organisms and volcanic glass.

No. 9. Station 14, 7.th September, 1899.

Lat. $6^{\circ} 41^{\prime}$ N. ; long. $137^{\circ} 0^{\prime} \mathrm{W}$.; depth, 2776 fathoms.

GLOBIGERINA OOZE: light brown.

Calcium carbonate: 44.2 per cent, broken Foraminifera, coccoliths, rhabdoliths, Echinoid spines.

REsidue : 55.8 per cent, brown, very flocculent:-

Siliceous Organisms (15 per cent), Radiolaria and Diatoms, with one or two Sponge spicules.

Minerals ( 1 per cent), angular, mean diameter $0.1 \mathrm{~mm}$., pumice, glassy particles, and felspar.

Fine Washings (39.8 per cent), amorphous clayey matter, with minute mineral particles and fragments of Radiolaria, etc.

No. 10. Station 15, 8th September, 1899.

Lat. $4^{\circ} 35^{\prime} \mathrm{N}$. ; long. $136^{\circ} 54^{\prime} \mathrm{W}$.; depth, 2583 fathoms.

GLOBIGERINA OOZE : light brown.

Calcium carbonate: 65.35 per cent, fragments of Foraminifera, small Gasteropods, coccoliths, rhabdoliths, Fish teeth.

Residue : 34.65 per cent, dark brown, flocculent :-

Siliceous Organisms (10 per cent), Radiolaria, Diatoms, Sponge spicules.

Minerals (1 per cent), angular, mean diameter $0.06 \mathrm{~mm}$., felspar and glassy particles.

Fine Washings (23.65 per cent), amorphous flocculent clayey matter, with fragments of Radiolaria and Diatoms. 
No. 11. Station 16, 9th September, 1899.

Lat. $2^{\circ} 38^{\prime} \mathrm{N}$. ; long. $137^{\circ} 22^{\prime} \mathrm{W}$.; depth, 2440 fathoms.

GLOBIGERINA OOZE : brownish gray.

Calcium carbonate: 70.75 per cent, pelagic Foraminifera, coccoliths, rhabdoliths, and Echinoid spines.

RESIDUE : 29.25 per cent, dark brown :-

Siliceous Organisms (10 per cent), Radiolaria, Diatoms, Sponge spicules, arenaceous Foraminifera.

Minerals (1 per cent), angular, mean diameter $0.06 \mathrm{~mm}$., felspar and glassy particles.

Fine Washings (18.25 per cent), amorphous clayey matter, and fragments of Radiolaria.

No. 12. Station 17, 10th September, 1899.

Lat. $0^{\circ} 50^{\prime} \mathrm{N}$. ; long. $137^{\circ} 54^{\prime} \mathrm{W}$.; depth, 2463 fathoms.

GLOBIGERINA OOZE: cream colored, granular, coherent.

Calcium CaRbonate: 64.85 per cent, pelagic Foraminifera, rhabdoliths, and coccoliths.

RESIDUE : 35.15 per cent, light yellowish brown, flocculent:-

Siliceous organisms (5 per cent), Radiolaria, Diatoms, Sponge spicules.

Minerals (1 per cent), mean diameter $0.06 \mathrm{~mm}$., a few glassy particles.

Fine Washings (29.15 per cent), amorphous clayey matter, with fragments of siliceous organisms.

No. 13. Station 18, 13th September, 1899.

Lat. $6^{\circ} 25^{\prime} \mathrm{S}$. ; long. $138^{\circ} 59^{\prime} \mathrm{W}$.; depth, 2475 fathoms.

GLOBIGERINA OOZE : cream colored, granular, coherent.

Calcium carbonate: 72.4 per cent, pelagic and bottom-living Foraminifera, Echinoid spines, Cephalopod beak, coccoliths, rhabdoliths, and minute calcareous bodies in form like a horseshoe.

Residue : 27.6 per cent, light brown :-

Siliceous Organisms (5 per cent), Radiolaria, Sponge spicules, and Diatoms.

Minerals (1 per cent), mean diameter $0.08 \mathrm{~mm}$., angular, pumice, felspar, and glassy particles.

Fine Washings (21.6 per cent), fragments of Diatoms, Radiolaria, and minute mineral particles, with clayey matter. 
No. 14. Station 19, 13th September, 1899.

Lat. $7^{\circ} 58^{\prime} \mathrm{S}$. ; long. $139^{\circ} 09^{\prime} \mathrm{W}$.; depth, 2287 fathoms.

GLOBIGERINA OOZE : dirty gray in color.

Calcium Carbonate: 70.7 per cent, pelagic and bottom-living Foraminifera, Ostracodes, coccoliths, and rhabdoliths.

Residue : 29.3 per cent, brown :-

Siliceous Organisms (5 per cent), Sponge spicules, Radiolaria, Diatoms, arenaceous Foraminifera.

Minerals ( 1 per cent), mean diameter $0.08 \mathrm{~mm}$., angular, felspar, volcanic glass, pumice, magnetite.

Fine Washings (23.3 per cent), clayey matter, with minute mineral particles and fragments of siliceous organisms.

No. 15. Station 20, 14th September, 1899.

Lat. $8^{\circ} 13^{\prime} \mathrm{S}$. ; long. $139^{\circ} 10^{\prime} \mathrm{W}$.; depth, 2267 fathoms.

GLOBIGERINA OOZE: gray, granular, slightly coherent.

Calcium carbonate: 69.35 per cent, pelagic and bottom-living Foraminifera, coccoliths, rhabdoliths, small Fish teeth, and minute calcareous bodies (horseshoe shaped).

REsidue : 30.65 per cent, black mineral particles with reddish-brown flocculent clayey matter :-

Siliceous Organisms (2 per cent), Sponge spicules, Radiolaria, arenaceous Foraminifera.

Minerals ( 4 per cent), angular, mean diameter $0.1 \mathrm{~mm}$., palagonite, plagioclase, decomposed ferro-magnesian minerals.

Fine Washings (24.65 per cent), flocculent amorphous clayey matter, with minute mineral particles and fragments of siliceous organisms.

No. 16. Station 21, 14th September, 1899.

Lat. $8^{\circ} 28^{\prime} \mathrm{S}$. ; long. $139^{\circ} 12^{\prime} \mathrm{W}$.; depth, 2183 fathoms.

GLOBIGERINA OOZE: cream colored, granular, slightly coherent.

Calcium carbonate: 65.75 per cent, pelagic and bottom-living Foraminifera, Echinoid spines, rhabdoliths, coccoliths, and other small calcareous bodies (horseshoe shaped).

REsIDUE : 34.25 per cent, yellowish-brown, flocculent, clayey matter, with black mineral particles. 
THE DEPTH AND MARINE DEPOSITS OF THE PACIFIC OCEAN. 87

Siliceous Organisms (5 per cent), Radiolaria, Sponge spicules, Diatoms, arenaceous Foraminifera.

Minerals ( 5 per cent), angular, mean diameter $0.1 \mathrm{~mm}$., felspar, obsidian, magnetite.

Fine Washings (24.25 per cent), amorphous clayey matter, with minute mineral particles and fragments of siliceous organisms.

No. 17. Station 22, 14th September, 1899.

Lat. $8^{\circ} 31^{\prime} \mathrm{S}$. ; long. $139^{\circ} 26^{\prime} \mathrm{W}$.; depth, 1939 fathoms.

GLOBIGERINA OOZE: gray, granular, slightly coherent.

Calcium carbonate: 70.9 per cent, pelagic and bottom-living Foraminifera, rhabdoliths, coccoliths, and other minute calcareous bodies (horseshoe shaped).

REsidue : 29.1 per cent, yellowish-brown, flocculent, clayey matter, with black deposit of mineral particles :-

Siliceous Organisms (3 per cent), Radiolaria, Diatoms, arenaceous Foraminifera, and Sponge spicules.

Minerals (5 per cent), angular, mean diameter $0.08 \mathrm{~mm}$., felspar (plagioclase), augite, obsidian, magnetite, hematite.

Fine Washings (21.1 per cent), amorphous clayey matter, with Radiolarian and Diatom fragments, and minute mineral particles.

No. 18. Station 23, 14th September, 1899.

Lat. $8^{\circ} 33^{\prime}$ S. ; long. $139^{\circ} 36^{\prime}$ W.; depth, 1802 fathoms.

GLOBIGERINA OOZE: gray, granular, slightly coherent.

Calcium carbonate: 69.5 per cent, pelagic and bottom-living Foraminifera, Echinoid spines, and small calcareous horseshoe-shaped bodies.

RESIDUE : 30.5 per cent, flocculent, brownish-yellow, clayey matter, with large amount of black mineral matter:-

Siliceous Organisms (2 per cent), Radiolaria, Diatoms, arenaceous Foraminifera, Sponge spicules.

Minerals (10 per cent), angular, mean diameter $0.1 \mathrm{~mm}$., augite, olivine, magnetite, felspar (plagioclase, mostly kaolinized), chloritic minerals, manganese grains, palagonite.

Fine Washings (18.5 per cent), amorphous clayey matter, with minute mineral particles and fragments of siliceous organisms. 
No. 19. Station 31, 19th September, 1899.

Lat. $12^{\circ} 20^{\prime}$ S. ; long. $144^{\circ} 15^{\prime}$ W.; depth, 2700 fathoms.

RED CLAY : dark chocolate colored, coherent.

Calcium carbonate: 8 per cent, pelagic and bottom-living Foraminifera (mostly fragmentary), Fishes' teeth, coccoliths.

Residue : 92 per cent, chocolate colored :-

Siliceous Organisms (1 per cent), Sponge spicules, Radiolaria, arenaceous Foraminifera.

Minerals (5 per cent), angular, mean diameter $0.1 \mathrm{~mm}$., phillipsite (abundant, in isolated crystals, and in aggregations), manganese grains, magnetite, palagonite, plagioclase, augite.

Fine Washings (86 per cent), amorphous clayey matter, with many minute phillipsite crystals, and other mineral particles.

No. 20. Station 32, 20th September, 1899.

Lat. $13^{\circ} 37^{\prime}$ S.; long. $145^{\circ} 42^{\prime}$ W.; depth, 2451 fathoms.

RED CLAY: dark chocolate colored, coherent. Manganese nodule one inch by half an inch.

Calcium carbonate: 21.4 per cent, fragments of pelagic and bottomliving Foraminifera, Echinoid spines, Fish teeth, coccoliths, and small calcareous horseshoe-shaped bodies.

REsidue : 78.6 per cent, chocolate colored:-

Siliceous Organisms (1 per cent), Sponge spicules, arenaceous Foraminifera.

Minerals (10 per cent), angular and rounded; mean diameter $0.1 \mathrm{~mm}$., phillipsite (in individuals, twins, stellate, and subspherical groups, the last mentioned $1 \mathrm{~mm}$. in maximum diameter), palagonite, decomposed olivine, decomposed plagioclase, augite, manganese grains, magnetite, and a small cosmic spherule, $0.03 \mathrm{~mm}$. in diameter.

Fine Washings (67.6 per cent), amorphous clayey matter, with small phillipsite crystals, etc.

No. 21. Station 33, 20th September, 1899.

Lat. $14^{\circ} 10^{\prime} \mathrm{S}$. ; long. $146^{\circ} 10^{\prime} \mathrm{W}$.; depth, 2527 fathoms.

RED CLAY : very dark chocolate color, almost black, coherent.

Calcium carbonate: 3.5 per cent, bottom-living Foraminifera and minute fragments of pelagic Foraminifera. 
THE DEPTH AND MARINE DEPOSITS OF THE PACIFIC OCEAN. 89

Residue: 96.5 per cent, black :-

Siliceous Organisms (1 per cent), Radiolaria.

Minerals (5 per cent), angular and rounded, mean diameter $0.1 \mathrm{~mm}$., consisting largely of 'manganese grains, rounded balls of phillipsite, felspar, and glass.

Fine Washings (90.5 per cent), amorphous clayey matter, with minute manganese grains and phillipsite crystals.

No. 22. Station 35, 21st September, 1899.

Lat. $14^{\circ} 42^{\prime}$ S. ; long. $147^{\circ} 08^{\prime}$ W.; depth, 1462 fathoms.

GLOBIGERINA OOZE : dirty cream colored, granular, incoherent.

Calcium carbonate: 74 per cent, pelagic and bottom-living Foraminifera, coccoliths, rhabdoliths, and other small calcareous horseshoe-shaped bodies.

Residue: 26 per cent, reddish-yellow, flocculent, very little heavy matter :-

Siliceous Organisms (1 per cent), Sponge spicules, Radiolaria.

Minerals ( 1 per cent), a few angular fragments, mean diameter $0.08 \mathrm{~mm}$., felspar, and glass.

Fine Washings (24 per cent), amorphous clayey matter, with minute mineral fragments, etc.

No. 23. Station 40, 24th September, 1899.

Avatoru Passage, Paumotu Islands; depth, 661 fathoms.

PTEROPOD OOZE : cream color, coherent.

Calcium carbonate : 77.3 per cent, Pteropods, Heteropods, pelagic and bottom-living Foraminifera, Echinoid spines, coccoliths, rhabdoliths, Tunicate spicules, otoliths of Fish, Molluscan shell-fragments, small Lamellibranchs, and small calcareous horseshoe-shaped bodies.

Residue : 22.7 per cent, brown, flocculent :-

Siliceous Organisms (1 per cent), Sponge spicules, Radiolaria, arenaceous Foraminifera.

Minerals (1 per cent), angular, mean diameter $0.06 \mathrm{~mm}$., one or two glassy particles and felspar. There is very little mineral matter, considerably less than 1 per cent.

Fine Washings (20.7 per cent), amorphous clayey matter, with very small mineral particles, etc. 
No. 24. Station 41, 24th September, 1899.

Avatoru Passage, Paumotu Islands; depth, 684 fathoms.

PTEROPOD OOZE: cream colored with a tinge of pink, incoherent, finegrained.

Calcium carbonate: 80 per cent, Pteropods, Heteropods (Atlanta), pelagic and bottom-living Foraminifera, Echinoid spines, fragments of Molluse shells (small Gasteropod shells, like Pleurotoma, and Bivalves), coccoliths, rhabdoliths, Tunicate spicules.

Residue : 20 per cent, brown, flocculent : -

Siliceous Organisms (1 per cent), arenaceous Foraminifera, Sponge spicules, Radiolaria.

Minerals (1 per cent), angular glassy particles, one or two having a mean diameter of $0.06 \mathrm{~mm}$.

Fine Washings (18 per cent), amorphous clayey matter, with minute particles of volcanic glass, etc.

No. 25. Station 47, 24th September, 1899.

About 7 miles off the south coast of Rangiroa, Paumotu Islands; depth, 764 fathoms.

PTEROPOD OOZE: cream colored, slightly coherent.

Calcium carbonate : 80 per cent, Pteropods, Heteropods, pelagic and bottom-living Foraminifera, Echinoid spines, Coral fragments, Molluse-shell fragments, small calcareous concretions containing pelagic Foraminifera, Alcyonarian spicules, coccoliths, rhabdoliths, Tunicate spicules.

Residue : 20 per cent, brown, flocculent :-

Siliceous Organisms (1 per cent), Sponge spicules, Radiolaria, arenaceous Foraminifera.

Minerals (1 per cent), angular particles of felspar and obsidian, mean diameter $0.08 \mathrm{~mm}$., manganese grains, and small cosmic spherule.

Fine Washings (18 per cent), amorphous clayey matter, with very few minute mineral particles and fragments of siliceous organisms.

No. 26. Station 62, 26th September, 1899.

Lat. $15^{\circ} 33^{\prime}$ S. ; long. $148^{\circ} 45^{\prime} \mathrm{W}$.; depth, 2267 fathoms.

GLOBIGERINA OOZE : light brown, with gray patches, slightly coherent.

Calcium carbonate: 67.15 per cent, very small pelagic and bottom- 
THE DEPTH AND MARINE DEPOSITS OF THE PACIFIC OCEAN. 91

living Foraminifera, coccoliths, rhabdoliths, Tunicate spicules, and sinall calcareous horseshoe-shaped bodies.

REsIDUE : 32.85 per cent, chocolate colored, flocculent :-

Siliceous Organisms (1 per cent), Sponge spicules, Radiolaria, arenaceous Foraminifera.

Minerals (1 per cent), angular, mean diameter 0.07 mm., felspar, magnetite, obsidian, and one twin crystal of phillipsite observed.

Fine Washings (30.85 per cent), amorphous clayey matter, with small mineral particles and fragments of siliceous organisms.

No. 27. Station 63, 26th September, 1899.

Lat. $15^{\circ} 42^{\prime}$ S.; long. $148^{\circ} 44^{\prime}$ W. ; depth, 2247 fathoms.

GLOBIGERINA OOZE : brownish-red, coherent, clayey.

Calcium Carbonate: 56.9 per cent, pelagic and bottom-living Foraminifera (mostly small, some broken), coccoliths, rhabdoliths.

Residue : 43.1 per cent, chocolate brown, flocculent :-

Siliceous Organisms (1 per cent), Sponge spicules, Radiolaria.

Minerals (2 per cent), angular, mean diameter $0.1 \mathrm{~mm}$, felspar, hornblende, obsidian, magnetite, small fragment of pumice $0.2 \mathrm{~mm}$. in diameter, manganese grains.

Fine Washings (40.1 per cent), amorphous clayey matter, with minute mineral particles, etc.

No. 28. Station 67, 27th September, 1899.

Lat. $16^{\circ} 32^{\prime}$ S. ; long. $148^{\circ} 40^{\prime}$ W.; depth, 2363 fathoms.

GLOBIGERINA OOZE : grayish-brown, coherent, clayey.

Calcium carbonate : 39.6 per cent, Foraminifera, - pelagic (mostly fragmentary) and bottom-living,_-Ostracodes, Echinoid spines, small Fish teeth, rhabdoliths, coccoliths.

RESIDUE : 60.4 per cent, brown, flocculent:-

Siliceous Organisms (2 per cent), Radiolaria, Sponge spicules, arenaceous Foraminifera.

Minerals (5 per cent), angular, mean diameter $0.08 \mathrm{~mm}$., plagioclase, augite, obsidian, magnetite.

Fine Washings (53.4 per cent), amorphous clayey matter, with minute mineral particles, etc. 
No. 29. Station 68, 27th September, 1899.

Lat. $16^{\circ} 57^{\prime}$ S. ; long. $148^{\circ} 58^{\prime}$ W. ; depth, 2224 fathoms.

RED CLAY : grayish-brown, coherent, clayey.

Calcium carbonate : 27.75 per cent, pelagic and bottom-living Foraminifera, Fishes' teeth, Ostracodes, Echinoid spines.

RESIDUE: 72.25 per cent, brown, flocculent, with heavy mineral particles :-

Siticeous Organisms (2 per cent), arenaceous Foraminifera, Radiolaria, Sponge spicules, Diatoms.

Minerals (30 per cent), angular, mean diameter $0.1 \mathrm{~mm}$., augite, olivine, magnetite, felspar (plagioclase), hematite, chloritic mineral, biotite (1 or 2 flakes).

Fine Washings (40.25 per cent), amorphous clayey matter, with minute mineral particles, etc.

No. 30. Station 70, 27th September, 1899.

Lat. $17^{\circ} 21^{\prime}$ S. ; long. $149^{\circ} 15^{\prime} \mathrm{W}$; ; depth, 1585 fathoms.

VOLCANIC MUD : dark grayish-brown, coherent, clayey, slightly gritty to the touch.

Calcium carbonate: 20.2 per cent, pelagic and bottom-living Foraminifera, Echinoid spines, Ostracodes, coccoliths, rhabdoliths.

REsIDUE : 79.8 per cent, brown, flocculent, with a great many mineral particles :-

Siliceous Organisms (2 per cent), arenaceous Foraminifera, Radiolaria, Sponge spicules.

Minerals (50 per cent), angular, mean diameter $0.12 \mathrm{~mm}$., olivine, augite, magnetite, hematite, chloritic mineral, felspar, volcanic glass.

Fine Washings (27.8 per cent), amorphous clayey matter, with a large amount of minute mineral particles.

No. 31. Station 74, 5th October, 1899.

Lat. $17^{\circ} 28.4^{\prime}$ S. ; long. $149^{\circ} 34^{\prime} \mathrm{W}$.; depth, 807 (?) fathoms.

VOLCANIC MUD: grayish-black, coherent, clayey; on treatment with dilute hydrochloric acid a strong smell of sulphuretted hydrogen is given off, due to organic matter (portions of leaves, bark of trees, etc.).

Calcium carbonate : 30 per cent, pelagic and bottom-living Foraminifera, 
THE DEPTH AND MARINE DEPOSITS OF THE PACIFIC OCEAN. 93

Heteropods, Pteropods, Polyzoa, Echinoid spines, Ostracodes, otoliths, small Gasteropods and Lamellibranchs, Tunicate spicules, coccoliths, rhabdoliths.

Residue : 70 per cent, black with greenish tinge, many coprolites :-

Siticeous Organisms (3 per cent), arenaceous Foraminifera, Radiolaria, Sponge spicules, Diatoms.

Minerals (20 per cent), angular, mean diameter $0.1 \mathrm{~mm}$, augite, olivine, oligoclase, sanidine (?), volcanic glass, magnetite very abundant.

Fine. Washings (47 per cent), amorphous clayey matter, with small coprolites, mineral particles, and fragments of siliceous organisms.

No. 32. Station 75, 5th Oetober, 1899.

Lat. $16^{\circ} 57^{\prime}$ S. ; long. $147^{\circ} 29^{\prime} \mathrm{W}$.; depth, 1592 fathoms.

GLOBIGERINA OOZE : grayish-brown, coherent, granular.

Calcium carbonate: 40.75 per cent, pelagic and bottom-living Foraminifera, otoliths, Ostracodes, Echinoid spines, Coral fragments, coccoliths, rhabdoliths, Tunicate spicules.

REsidue: 59.25 per cent, brown, flocculent, with black mineral particles :-

Siliceous Organisms (2 per cent), Radiolaria, Sponge spicules, arenaceous Foraminifera, Diatoms.

Minerals (10 per cent), angular, mean diameter $0.08 \mathrm{~mm}$., augite, olivine, plagioclase, magnetite, chloritic mineral.

Fine Washings (47.25 per cent), amorphous clayey matter, with minute mineral particles and fragments of siliceous organisms.

No. 33. Station 94, 14th October, 1899.

Lat. $16^{\circ} 57^{\prime}$ S.; long. $145^{\circ} 49^{\prime}$ W. ; depth, 1531 fathoms.

GLOBIGERINA OOZE: cream colored, slightly coherent.

Calcium Carbonate: 81.45 per cent, Foraminifera, - pelagic (including a large proportion of young forms) and bottom-living, - Ostracodes, otoliths, coccoliths, rhabdoliths.

Residue : 18.55 per cent, brown, flocculent:-

Siliceous Organisms (2 per cent), Radiolaria, Sponge spicules, imperfect casts, Diatoms.

Minerals (1 per cent), mean diameter $0.06 \mathrm{~mm}$., only one or two particles of felspar and glass observed.

Fine Washings (15.55 per cent), amorphous clayey matter, with splinters of siliceous organisms and minute mineral particles. 
No. 34. Station 102, 15 th October, 1899.

Lat. $17^{\circ} 10^{\prime} \mathrm{S}$. ; long. $145^{\circ} 19^{\prime} \mathrm{W}$.; depth, 1679 fathoms.

GLOBIGERINA OOZE: cream colored, slightly coherent.

Calcium carbonate: 84.3 per cent, pelagic and bottom-living Foraminifera, Echinoid spines, Ostracodes, otoliths, Tunicate spicules, coccoliths, rhabdoliths.

REsidue : 15.7 per cent, yellowish-brown :-

Siticeous Organisms (1 per cent), Radiolaria, Sponge spicules.

Minerals (1 per cent), angular, mean diameter $0.06 \mathrm{~mm}$., plagioclase, obsidian, altered hornblende (chloritized), magnetite.

Fine Washings (13.7 per cent), amorphous clayey matter, with minute mineral particles, etc.

No. 35. Station 109, 16th October, 1899.

Lat. $16^{\circ} 13^{\prime}$ S. ; long. $143^{\circ} 48^{\prime} \mathrm{W}$.; depth, 987 fathoms.

GLOBIGERINA OOZE : dirty cream colored, slightly coherent.

Calcium carbonate: 79.4 per cent, pelagic and bottom-living Foraminifera, Pteropod fragments, small Lamellibranchs and Gasteropods, Ostracodes, otoliths, Tunicate spicules, coccoliths, rhabdoliths.

Residue : 20.6 per cent, yellowish-brown, flocculent :-

Siliceous Organisms (1 per cent), Radiolaria, Sponge spicules, Diatoms.

Minerals (traces), angular, mean diameter $0.06 \mathrm{~mm}$., felspar, obsidian, magnetite.

Fine Washings (19.6 per cent), amorphous clayey matter, etc.

No. 36. Station 113, 17th October, 1899.

Lat. $15^{\circ} 55^{\prime} \mathrm{S}$. ; long. $142^{\circ} 39^{\prime} \mathrm{W}$.; depth, 1503 fathoms.

GLOBIGERINA OOZE : cream colored, slightly coherent.

Calcium carbonate: 80 per cent, pelagic and bottom-living Foraminifera, Ostracodes, otoliths, coccoliths, rhabdoliths, fragments of Cephalopod bone.

Residue: 20 per cent, yellowish brown, flocculent:-

Siliceous Organisms (1 per cent), Radiolaria, Sponge spicules.

Minerals (1 per cent), angular, mean diameter $0.1 \mathrm{~mm}$., felspar, obsidian, and magnetite.

Fine Washings (18 per cent), amorphous clayey matter, with minute mineral particles and fragments of Radiolaria. 
No. 37. Station 136, 28th October, 1899.

Lat. $18^{\circ} 8^{\prime}$ S. ; long. $141^{\circ} 49^{\prime}$ W.; depth, 2187 fathoms.

GLOBIGERINA OOZE : reddish-brown, with lighter-colored patches, slightly coherent, clayey.

Calcium carbonate : 74.2 per cent, pelagic and bottom-living Foraminifera, Echinoid spines, Ostracodes, Alcyonarian spicules, coccoliths, rhabdoliths, Tunicate spicules.

RESIDUE : 25.8 per cent, chocolate colored, flocculent :-

Siliceous Organisms (1 per cent), Sponge spicules, Radiolaria, Diatoms, arenaceous Foraminifera.

Minerals (5 per cent), angular, mean diameter $0.1 \mathrm{~mm}$., obsidian (brown, clear, and yellow fragments, some of the latter showing spherulitic structure), felspar, augite, magnetite, manganese grains, phillipsite in isolated crystals and rounded aggregates.

Fine Washings (19.8 per cent), amorphous clayey matter, with minute mineral particles and fragments of siliceous organisms.

No. 38. Station 140, 29th October, 1899.

Lat. $18^{\circ} 27^{\prime}$ S. ; long. $140^{\circ} 21^{\prime}$ W.; depth, 2042 fathoms.

GLOBIGERINA OOZE: light brown, coherent.

Calcium carbonate: 72.95 per cent, pelagic and bottom-living Foraminifera, Echinoid spines, otoliths, Ostracodes, coccoliths, rhabdoliths, small Lamellibranchs and Gasteropods.

Residue : 27.05 per cent, chocolate colored, flocculent :-

Siliceous Organisms (1 per cent), Sponge spicules, Radiolaria.

Minerals (1 per cent), angular, mean diameter $0.07 \mathrm{~mm}$., volcanic glass, felspar, augite (?), decomposed ferro-magnesian minerals, manganese grains.

Fine Washings (25.05 per cent), amorphous clayey matter, with minute mineral particles and fragments of siliceous organisms.

No. 39. Station 142, 30th October, 1899.

Lat. $18^{\circ} 30^{\prime}$ S. ; long. $139^{\circ} 30^{\prime} \mathrm{W}$.; depth, 2103 fathoms.

GLOBIGERINA OOZE : light brown, coherent.

Calcium carbonate: 77.5 per cent, pelagic and bottom-living Foraminifera, Echinoid spines, Ostracodes, otoliths, coccoliths, rhabdoliths.

RESIDUE : 22.5 per cent, chocolate colored, flocculent :-

Siticeous Organisms (1 per cent), Sponge spicules, Radiolaria. 
Minerals (2 per cent), angular, mean diameter $0.08 \mathrm{~mm}$. , felspar, obsidian, pumice, isolated crystals of phillipsite, augite, small manganese grains.

Fine Washings (19.5 per cent), amorphous clayey matter, with minute mineral particles, and fragments of siliceous organisms.

No. 40. Station 146, 31st October, 1899.

Lat. $18^{\circ} 36^{\prime} \mathrm{S}$. ; long. $139^{\circ} 14^{\prime} \mathrm{W}$.; depth, 1725 fathoms.

RED CLAY : very little material; brown, clayey, and coherent.

Calcium carbonate: 30 per cent, fragments of pelagic and bottomliving Foraminifera, coccoliths, small Fish teeth.

REsidue : 70 per cent, brown, flocculent :-

Siticeous Organisms (1 per cent), Radiolaria, Sponge spicules.

Minerals (10 per cent), angular, mean diameter $0.08 \mathrm{~mm}$., obsidian, felspar, magnetite, and manganese grains.

Fine Washings (59 per cent), amorphous clayey matter, with minute mineral particles, and fragments of siliceous organisms.

No. 41. Station 151, 31st October, 1899.

Lat. $19^{\circ} 27^{\prime}$ S. ; long. $138^{\circ} 47^{\prime}$ W. ; depth, 1907 fathoms.

GLOBIGERINA OOZE: light brown or cream color, slightly coherent, finely granular.

Calcium carbonate: 85 per cent, pelagic Foraminifera with large proportion of young forms, one or two blackened by manganese, bottom-living Foraminifera, Ostracodes, coccoliths, rhabdoliths.

Residue: 15 per cent, brown, flocculent:-

Siticeous Organisms (2 per cent), Radiolaria, Sponge spicules, Diatoms.

Minerals (1 per cent), mean diameter $0.06 \mathrm{~mm}$., angular and rounded, a few particles of pumice, volcanic glass, and manganese grains.

Fine Washings (12 per cent), amorphous clayey matter.

No. 42. Station 152, 31st October, 1899.

Lat. $19^{\circ} 35^{\prime} \mathrm{S}$. ; long. $139^{\circ} 13^{\prime} \mathrm{W}$.; depth, 2335 fathoms.

RED CLAY or GLOBIGERINA OOZE: dark brown or chocolate color with yellow patches, coherent, clayey, granular to the touch.

Calcium carbonate: 33.6 per cent, pelagic and bottom-living Foraminifera, Fishes' teeth, coccoliths, and rhabdoliths observed, but the greater 
TIE DEPTH $\Lambda$ ND MARINE DEPOSITS OF THE PACIFIC OCEAN, 97

part of the material soluble in hydrochloric acid is in a crystalline form, apparently reef fragments more or less transformed into dolomite (dolomitic limestone).

Residue : 66.4 per cent, chocolate colored :-

Siliceous Organisms (1 per cent), Sponge spicules.

Minerals (30 per cent), mean diameter $0.15 \mathrm{~mm}$., rounded and angular, phillipsite, palagonite, volcanic glass, decomposed plagioclase, manganese grains, some of which attain a diameter of $4 \mathrm{~mm}$., hematite, magnetite, decomposed minerals.

Fine Washings (35.4 per cent), amorphous clayey matter impregnated with manganese.

This deposit is most peculiar, and would merit a close examination, but unfortunately little material is available.

No. 43. Station 156, 2nd November, 1899.

Lat. $20^{\circ} 31^{\prime} \mathrm{S}$. ; long. $142^{\circ} 0^{\prime} \mathrm{W}$.; depth, 2468 fathoms.

RED CLAY : very little material, dark brown, with yellow patches, coherent, clayey.

Calcium Carbonate: 25.85 per cent, small pelagic and fragments of bottom-living Foraminifera, Echinoid spines, Fish teeth and otoliths, coccoliths, and other calcareous horseshoe-shaped bodies.

RESIDUE : 74.15 per cent, chocolate colored:-

Siliceous Organisms (1 per cent), Sponge spicules, arenaceous Foraminifera.

Minerals (30 per cent), angular and rounded, mean diameter $0.15 \mathrm{~mm}$., phillipsite in isolated crystals, twins, and aggregates, manganese grains, plagioclase, volcanic glass, palagonite, angite. (Some of the phillipsite aggregates attain a diameter of $0.5 \mathrm{~mm}$., and some of the manganese grains $1 \mathrm{~mm}$.)

Fine Washings (43.15 per cent), amorphous clayey matter, with many minute mineral particles.

No. 44. Station 157, 2nd November, 1899.

Lat. $20^{\circ} 46.5^{\prime} \mathrm{S}$; ; long. $142^{\circ} 51^{\prime} \mathrm{W}$.; depth, 2315 fathoms.

GLOBIGERINA OOZE: very little material, dark brown, with white spots (Foraminifera), coherent, clayey, with fragments of decomposed volcanic glass impregnated with manganese, the largest being $7 \mathrm{~mm}$. in diameter.

Calcium carbonate: 41.8 per cent, the mean of two analyses which 
gave 40.4 and 43.1 respectively; small pelagic Foraminifera, fragments of bottom-living Foraminifera, Fish teeth, coccoliths, rhabdoliths, and other calcareous, horseshoe-shaped bodies.

Residue: 58.2 per cent, dark brown :-

Siticeous Organisms (1 per cent), Sponge spicules, Radiolaria.

Minerals (20 per cent), rounded and angular, mean diameter $0.2 \mathrm{~mm}$., volcanic glass, palagonite, felspar, manganese grains, phillipsite, magnetite.

Fine Washings (37.2 per cent), amorphous clayey matter, with many small mineral particles.

No. 45. Station 167, 3rd November, 1899.

Lat. $20^{\circ} 2^{\prime}$ S. ; long. $144^{\circ} 28^{\prime} \mathrm{W}$.; depth, 2524 fathoms.

RED CLAY : chocolate color, extremely clayey.

Calcium carbonate: 3.7 per cent, pelagic Foraminifera and their fragments, Fish teeth, crystalline calcareous particles (dolomitic limestone fragments).

REsidue : 96.3 per cent, chocolate colored :-

Siliceous Organisms (1 per cent), Sponge spicules.

Minerals (10 per cent), mean diameter 0.05 to $0.1 \mathrm{~mm}$., angular and rounded, volcanic glass (some fragments attain a diameter of $1 \mathrm{~mm}$.), palagonite, phillipsite in isolated crystals, twins, and aggregates, magnetite, manganese grains, and other minerals too decomposed for determination.

Fine Washings (85.3 per cent), amorphous clayey matter, with minute mineral particles.

No. 46. Station 172, 3rd November, 1899.

Lat. $19^{\circ} 22^{\prime} \mathrm{S}$. ; long. $145^{\circ} 47^{\prime} \mathrm{W}$.; depth, 2322 fathoms.

GLOBIGERINA OOZE: dark brown, with light brown or yellow patches, coherent, clayey; has the appearance of a typical Red Clay, but the percentage of calcium carbonate is too high.

Calcium carbonate: 40.5 per cent, pelagic Foraminifera and their fragments (large proportion very small), bottom-living Foraminifera, Echinoid spines, coccoliths, rhabdoliths.

Residue: 59.5 per cent, chocolate colored :-

Siliceous Organisms (1 per cent), Sponge spicules.

Minerals (3 per cent), mean diameter $0.12 \mathrm{~mm}$., angular and rounded, volcanic glass, palagonite, manganese graius, plagioclase, phillipsite, magnetite. 
Fine Washings (55.5 per cent), amorphous clayey matter, with many small mineral particles.

No. 47. Station 173, 4th November, 1899.

Lat. $18^{\circ} 55^{\prime}$ S. ; long. $146^{\circ} 23^{\prime}$ W. ; depth, 2440 fathoms.

A large quantity of Red Clay, containing many manganese nodules, sharks' teeth, etc., was obtained by the trawl. No deposit from the sounding-tube was received, so the following description is prepared from clay from the trawl.

RED CLAY : dark brown or chocolate colored.

Calcium carbonate: 1 per cent, a few pelagic and bottom-living Foraminifera, Fish teeth, fragment of Gasteropod shell, and one or two coccoliths observed.

Residue : 99 per cent, chocolate colored :-

Siticeous Organisms (1 per cent), Sponge spicules, Radiolaria.

Minerals (25 per cent), mean diameter $0.15 \mathrm{~mm}$., angular and rounded, volcanic glass, Pele's hair, palagonite, pumice, olivine, manganese grains, magnetite, plagioclase, augite, cosmic spherules, many tuff fragments, and manganese grains of large size.

Fine Washings (73 per cent), amorphous clayey matter, with many minute minerals.

No. 48. Station 182, 23rd November, 1899.

Lat. $18^{\circ} 59^{\prime} \mathrm{S}$. ; long. $164^{\circ} 47^{\prime} \mathrm{W}$.; depth, 2882 fathoms.

RED CLAY : reddish brown, coherent, clayey.

Calcium carbonate: 0 per cent.

Residue: 100 per cent :-

Siliceous Organisms (1 per cent), fragments of Radiolaria.

Minerals (1 per cent), angular, mean diameter $0.08 \mathrm{~mm}$., pumice, magnetite, manganese grains.

Fine Washings (98 per cent), amorphous clayey matter, with minute mineral particles.

No. 49. Station 186, 27th November, 1899.

Lat. $21^{\circ} 18^{\prime} \mathrm{S}$. ; long. $173^{\circ} 51^{\prime} \mathrm{W}$.; depth, 4540 fathoms.

RED CLAY : brown, clayey, coherent.

Calcium carbonate: 0 per cent. 
RESIDUE : 100 per cent :-

Siliceous Organisms (1 per cent), Sponge spicules.

Minerals (30 per cent), mean diameter $0.15 \mathrm{~mm}$. , angular, pumice, decomposed plagioclase, obsidian, magnetite, manganese grains, augite, olivine, volcanic glass abundant.

Fine Washings (69 per cent), amorphous clayey matter, with minute mineral particles.

No. 50. Station 188, 6th December, 1899.

Lat. $18^{\circ} 43^{\prime}$ S.; long. $175^{\circ} 28^{\prime} \mathrm{W}$.; depth, 1381 fathoms.

RED CLAY or VOLCANIC MUD: brown, coherent, clayey.

Calcium Carbonate: 16.6 per cent, pelagic and bottom-living Foraminifera, small Fish teeth, coccoliths, and rhabdoliths.

RESIDUE : 83.4 per cent, dark brown, floceulent:-

Siliceous Organisms (1 per cent), fragments of Radiolaria and Sponge spicules.

Minerals (30 per cent), angular, mean diameter $0.2 \mathrm{~mm}$., plagioclase, pumice, volcanic glass, magnetite, olivine, augite (?).

Fine Washings (52.4 per cent), amorphous clayey matter, with minute mineral particles.

No. 51. Station 191, 7th December, 1899.

Lat. $18^{\circ} 56^{\prime} \mathrm{S}$; ; long. $178^{\circ} 43^{\prime} \mathrm{W}$.; depth, 600 fathoms.

PTEROPOD OOZE: dirty cream colored, slightly coherent.

Calcium carbonate: 82.5 per cent, Pteropods, Heteropods, pelagic and bottom-living Foraminifera, small Lamellibranchs and Gasteropods, Fish teeth, Polyzoa, Ostracodes, otoliths, coccoliths, rhabdoliths, Tunicate spicules.

Residue: 17.5 per cent, reddish brown, flocculent, with black mineral particles :-

Siticeous Organisms (1 per cent), Sponge spicules, Radiolaria, Diatoms.

Minerals (10 per cent), angular, mean diameter $0.1 \mathrm{~mm}$., pumice, volcanic glass, augite, magnetite, olivine, plagioclase.

Fine Washings (6.5 per cent), amorphous clayey matter, with minute mineral particles and fragments of siliceous organisms. 
THE DEPTI AND MARINE DEPOSITS OF THE PACIFIC OCEAN. 101

No. 52. Station 193, 9th December, 1899.

Lat. $18^{\circ} 56.5^{\prime} \mathrm{S}$; long. $179^{\circ} 16^{\prime} \mathrm{W}$.; depth, 990 fathoms.

GLOBIGERINA OOZE: dirty cream colored, coherent.

Calcium carbonate: 78.15 per cent, pelagic and bottom-living Foraminifera, Pteropods, Heteropods, Ostracodes, otoliths, Fish teeth, small Lamellibranchs and Gasteropods, Tunicate spicules, coccoliths, rhabdoliths.

RESIDUE : 21.85 per cent, brown, flocculent :-

Siliceous Organisms (1 per cent), Radiolaria, Sponge spicules, Diatoms.

Minerals (8 per cent), angular, mean diameter $0.08 \mathrm{~mm}$., pumice (the largest fragment 10 by 6 by $4 \mathrm{~mm}$.), volcanic glass, felspar, augite, olivine, magnetite.

Fine Washings (12.85 per cent), amorphous clayey matter, with minute mineral particles and fragments of siliceous organisms.

No. 53. Station 194, 21st December, 1899.

Lat. $12^{\circ} 43^{\prime} \mathrm{S}$. ; long. $179^{\circ} 50^{\prime} \mathrm{W}$.; depth, 1445 fathoms.

GLOBIGERINA OOZE: dirty cream colored, slightly coherent.

Calcium carbonate: 84 per cent, pelagic and bottom-living Foraminifera, coccoliths, rhabdoliths.

REsidue : 16 per cent, reddish brown, flocculent :-

Siliceous Organisms (1 per cent), Sponge spicules, Radiolaria.

Minerals (5 per cent), angular, mean diameter $0.08 \mathrm{~mm}$., pumice, volcanic glass, felspar, augite, magnetite, and manganese grains (the largest about $2 \mathrm{~mm}$. in diameter).

Fine Washings (10 per cent), amorphous clayey matter, with minute mineral particles and fragments of siliceous organisms.

From this station twelve rounded fragments of pumice were obtained in the trawl, the largest being 55 by $30 \mathrm{~mm}$. The pieces are partly decomposed, grayish brown in color, free from manganese. Some are close and fine-grained, others very vesicular. There was also a small fragment of a siliceous sponge.

No. 54. Station 197, 2nd January, 1900.

Lat. $0^{\circ} 30^{\prime}$ N. ; long. $173^{\circ} 35^{\prime}$ E. ; depth, 2221 fathoms.

GLOBIGERINA OOZE : cream colored, slightly coherent.

Calcium carbonate: 83.3 per cent, pelagic and bottom-living Foraminifera, Echinoid spines, otoliths, coccoliths, rhabdoliths. 
Residue : 16.7 per cent, light brown, flocculent :-

Siliceous Organisms (2 per cent), Radiolaria, Sponge spicules.

Minerals (1 per cent), angular, mean diameter $0.08 \mathrm{~mm}$. , volcanic glass, pumice, felspar.

Fine Washings (13.7 per cent), amorphous clayey matter, with minute mineral particles and fragments of siliceous organisms.

No. 55. Station 204, 4th January, 1900.

Lat. $1^{\circ} 52^{\prime} \mathrm{N}$. ; long. $173^{\circ} 15^{\prime} \mathrm{E}$. ; depth, 2156 fathoms.

GLOBIGERINA OOZE : cream colored, coherent.

Calcium carbonate: 73.7 per cent, pelagic and bottom-living Foraminifera, Echinoid spines, otoliths, coccoliths, rhabdoliths.

Residue : 26.3 per cent, brownish yellow, flocculent:-

Siliceons Organisms (3 per cent), Radiolaria, Sponge spicules, Diatoms.

Minerals ( 1 per cent), angular, mean diameter $0.06 \mathrm{~mm}$., felspar and volcanic glass.

Fine Washings (22.3 per cent), amorphous clayey matter, with minute mineral particles and fragments of siliceous organisms.

No. 56. Station 206, 5th January, 1900.

Lat. $2^{\circ} 27^{\prime} \mathrm{N}$. ; long. $173^{\circ} 09^{\prime} \mathrm{E}$; ; depth, 2255 fathoms.

GLOBIGERINA OOZE : dirty cream colored, coherent.

Calcium carbonate: 83 per cent, pelagic and bottom-living Foraminifera, Echinoid spines, otoliths, coccoliths, rhabdoliths.

RESIDUE : 17 per cent, brown, flocculent :-

Siliceous Organisms (3 per cent), Radiolaria, Sponge spicules, Diatoms, casts.

Minerals ( 1 per cent), angular, mean diameter $0.07 \mathrm{~mm}$., volcanic glass and felspar.

Fine Washings (13 per cent), amorphous clayey matter, with minute mineral particles and fragments of siliceous organisms.

No. 57. Station 208, 7th January, 1900.

Lat. $3^{\circ} 57^{\prime} \mathrm{N}$.; long. $172^{\circ} 0^{\prime}$ E.; depth, 2486 fathoms.

GLOBIGERINA OOZE : dirty cream colored, coherent, plastic, and clayey to the touch.

Calcium carbonate: 77.65 per cent, pelagic and bottom-living Foraminifera, Echinoid spines, coccoliths, rhabdoliths. 
Residue : 22.35 per cent, brown, flocculent :-

Siliceous Organisms (3 per cent), Radiolaria, Sponge spicules, Diatoms.

Minerals (1 per cent), angular, mean diameter $0.06 \mathrm{~mm}$., volcanic glass, felspar, and magnetite.

Fine Washings (18.35 per cent), amorphous clayey matter, with minute mineral particles and fragments of siliceous organisms.

No. 58. Station 209, 8th January, 1900.

Lat. $4^{\circ} 25^{\prime} \mathrm{N}$. ; long. $171^{\circ} 13^{\prime} \mathrm{E}$; depth, 2505 fathoms.

GLOBIGERINA OOZE: dirty cream colored, coherent.

Calcium carbonate: 77.35 per cent, pelagic and bottom-living Foraminifera, Echinoid spines, otoliths, Ostracodes, coccoliths, rhabdoliths.

Residue : 22.65 per cent, brown, flocculent:-

Siliceous Organisms (3 per cent), Radiolaria, Sponge spicules, Diatoms.

Minerals (1 per cent), angular, mean diameter $0.06 \mathrm{~mm}$., volcanic glass, felspar, and magnetite.

Fine Washings (18.65 per cent), amorphous clayey matter, with minute mineral particles and fragments of siliceous organisms.

No. 59. Station 210, 8th January, 1900.

Lat. $4^{\circ} 54^{\prime}$ N. ; long. $170^{\circ} 21^{\prime}$ E. ; depth, 2444 fathoms.

GLOBIGERINA OOZE: brownish gray.

Calcium CARbonate: 74 per cent, pelagic and bottom-living Foraminifera, Echinoid spines, Ostracodes, otoliths, coccoliths, rhabdoliths.

Residue : 26 per cent, brown, flocculent:-

Siticeous Organisms (3 per cent), Radiolaria, Sponge spicules, Diatoms.

Minerals (1 per cent), angular, mean diameter $0.07 \mathrm{~mm}$., felspar and volcanic glass.

Fine Washings (22 per cent), amorphous clayey matter, with minute siliceous splinters and small mineral particles.

No. 60. Station 211, 9th January, 1900.

Lat. $5^{\circ} 20^{\prime}$ N. ; long. $169^{\circ} 43^{\prime}$ E. ; depth, 2411 fathoms.

GLOBIGERINA OOZE: brownish gray, coherent, plastic.

Calcium carbonate : 80.75 per cent, pelagic and bottom-living Foraminifera, Echinoid spines, Ostracodes, coccoliths, rhabdoliths.

REsidue : 19.25 per cent, brown, flocculent :-

Siliceous Organisms (3 per cent), Radiolaria, Sponge spicules. 


\section{THE DEPTH AND MARINE DEPOSITS OF THE PACIFIC OCEAN.}

Minerals (1 per cent), angular, mean diameter $0.07 \mathrm{~mm}$., felspar, volcanic glass, augite, chloritic mineral.

Fine Washings (15.25 per cent), amorphous clayey matter, with minute mineral particles and fragments of siliceous organisms.

No. 61. Station 213, 14th January, 1900.

Lat. $6^{\circ} 34^{\prime}$ N. ; long. $169^{\circ} 13^{\prime}$ E. ; depth, 2613 fathoms.

GLOBIGERINA OOZE: brownish gray, coherent, plastic.

Calcium carbonate: 65.8 per cent, pelagic and bottom-living Foraminifera, Echinoid spines, otoliths, Ostracodes, coccoliths, rhabdoliths.

RESIDUE : 34.2 per cent, brown, flocculent :-

Siliceous Organisms (3 per cent), Radiolaria, Sponge spicules.

Minerals (1 per cent), angular, mean diameter $0.07 \mathrm{~mm}$., felspar and volcanic glass.

Fine Washings (30 per cent), amorphous clayey matter, with minute mineral particles and fragments of siliceous organisms.

No. 62. Station 219, 15th January, 1900.

Lat. $8^{\circ} 2^{\prime}$ N. ; long. $167^{\circ} 43^{\prime}$ E. ; depth, 2179 fathoms.

GLOBIGERINA OOZE : cream colored, coherent, plastic.

Calcium carbonate: 82.3 per cent, pelagic and bottom-living Foraminifera, Echinoid spines, otoliths, Ostracodes, coccoliths, rhabdoliths.

Residue : 17.7 per cent, brown, flocculent :-

Siliceous Organisms (5 per cent), Radiolaria, Sponge spicules, Diatoms.

Minerals (2 per cent), angular, mean diameter $0.1 \mathrm{~mm}$., volcanic glass, felspar, magnetite.

Fine Washings (10.7 per cent), amorphous clayey matter, with minute mineral particles and fragments of siliceous organisms.

No. 63. Station 220, 16th January, 1900.

Lat. $8^{\circ} 38^{\prime}$ N. ; long. $167^{\circ} 37^{\prime}$ E. ; depth, 1897 fathoms.

GLOBIGERINA OOZE: cream colored, coherent, plastic.

Calcium carbonate: 85.9 per cent, pelagic and bottom-living Foraminifera, Echinoid spines, Ostracodes, otoliths, coccoliths, rhabdoliths.

Residue : 14.1 per cent, brown, flocculent :-

Siliceous Organisms (3 per cent), Sponge spicules, Radiolaria.

Minerals (traces), angular, mean diameter $0.08 \mathrm{~mm}$., volcanic glass, decomposed ferro-magnesian minerals, manganese grains. 
THE DEPTH AND MARINE DEPOSITS OF THE PACIFIC OCEAN. 105

Fine Washings (11.1 per cent), amorphous clayey matter, with minute mineral particles and fragments of siliceous organisms.

No. 64. Station 223, 18th January, 1900.

Lat. $10^{\circ} 49^{\prime} \mathrm{N}$.; long. $167^{\circ} 15^{\prime} \mathrm{E}$. ; depth, 2469 fathoms.

GLOBIGERINA OOZE : reddish brown, coherent.

Calcium carbonate: 63.65 per cent, pelagic and bottom-living Foraminifera, many crystalline calcareous fragments (dolomitic limestone), otoliths, Ostracodes, fragments of Corals and Molluse shells, Echinoid spines, Alcyonarian spicules, coccoliths, rhabdoliths.

RESIDUE : 36.35 per cent, brown, flocculent, with small rock particles :-

Siliceous Organisms (2 per cent), Sponge spicules, Radiolaria.

Minerals (10 per cent), angular, mean diameter $0.4 \mathrm{~mm}$., palagonite, decomposed ferro-magnesian minerals, a little felspar, altered, but apparently orthoclase.

Fine Washings (24.35 per cent), amorphous clayey matter, with minute mineral particles and fragments of siliceous organisms.

No. 65. Station 224, 19 th January, 1900.

Lat. $10^{\circ} 30^{\prime}$ N. ; long. $167^{\circ} 42^{\prime}$ E. ; depth, 2586 fathoms.

GLOBIGERINA OOZE: brown, coherent, clayey.

Calcium carbonate: 54.9 per cent, pelagic and bottom-living Foraminifera, Coral fragments, Echinoid spines, otoliths, Ostracodes, coccoliths, crystalline calcareous particles (dolomitic limestone).

REsidue : 45.1 per cent, brown, flocculent :-

Siliceous Organisms (2 per cent), Radiolaria, Sponge spicules.

Minerals (10 per cent), angular, mean diameter, $0.3 \mathrm{~mm}$. , volcanic glass, palagonite, felspar, hornblende (?), olivine, magnetite.

Fine Washings (33.1 per cent), amorphous clayey matter, with minute mineral particles and fragments of siliceous organisms.

No. 66. Station 225, 19th January, 1900.

Lat. $10^{\circ} 15^{\prime} \mathrm{N}$. ; long. $168^{\circ} 6^{\prime} \mathrm{E}$.; depth, 2609 fathoms.

GLOBIGERINA OOZE : brown, coherent, clayey.

CAlcium carbonate: 45.35 per cent, pelagic and bottom-living Foraminifera, Echinoid spines, otoliths, Ostracodes, Coral fragments, coccoliths.

REsidue : 54.65 per cent, brown, flocculent:- 
Siliceous Organisms (3 per cent), Radiolaria, Sponge spicules.

Minerals (5 per cent), angular, mean diameter $0.1 \mathrm{~mm}$., volcanic glass, decomposed olivine, decomposed plagioclase, magnetite.

Fine Washings (46.65 per cent), amorphous clayey matter, with minute mineral particles and fragments of siliceous organisms.

No. 67. Station 226, 20th January, 1900.

Lat. $9^{\circ} 55^{\prime}$ N.; long. $168^{\circ} 56^{\prime}$ E. ; depth, 2231 fathoms.

GLOBIGERINA OOZE: cream colored, coherent, plastic.

Calcium Carbonate: 75.4 per cent, pelagic and bottom-living Foraminifera, Echinoid spines, Ostracodes, otoliths, Tunicate spicules, coccoliths, rhabdoliths.

Residue : 24.6 per cent, brown, flocculent :-

Siliceous Organisms (5 per cent), Radiolaria, Sponge spicules.

Minerals ( 1 per cent), angular, mean diameter $0.08 \mathrm{~mm}$., felspar, volcanic glass, and magnetite.

Fine Washings (18.6 per cent), amorphous clayey matter, with minute mineral particles and fragments of siliceous organisms.

No. 68. Station 232, 23rd January, 1900.

Lat. $8^{\circ} 50^{\prime} \mathrm{N}$. ; long. $170^{\circ} 26^{\prime} \mathrm{E}$; ; depth, 2221 fathoms.

GLOBIGERINA OOZE: cream colored, coherent.

Calcium Carbonate: 77.3 per cent, pelagic and bottom-living Foraminifera, Echinoid spines, otoliths, Ostracodes, coccoliths, rhabdoliths.

Residue : 22.7 per cent :-

Siticeous Organisms (2 per cent), Radiolaria, Sponge spicules.

Minerals (1 per cent), angular, mean diameter 0.08 mm., decomposed volcanic glass, felspar, magnetite, and augite.

Fine Washings (19.7 per cent), amorphous clayey matter, with minute mineral particles and fragments of siliceous organisms:

No. 69. Station 236, 28th January, 1900.

Lat. $6^{\circ} 34^{\prime} \mathrm{N}$. ; long. $170^{\circ} 59^{\prime}$ E. ; depth, 2482 fathoms.

GLOBIGERINA OOZE : grayish white, coherent, plastic.

Calcium carbonate: 73.15 per cent, pelagic and bottom-living Foraminifera, Echinoid spines, otoliths, Ostracodes, coccoliths, rhabdoliths.

RESIDUe : 26.85 per cent, brown, flocculent :- 
Siliceous Organisms (8 per cent), Radiolaria, Sponge spicules.

Minerals (3 per cent), angular, mean diameter $0.08 \mathrm{~mm}$., volcanic glass, plagioclase, augite, magnetite, fragment of decomposed pumice $3 \mathrm{~mm}$. in length, chloritic mineral.

Fine Washings (15.85 per cent), amorphous clayey matter, with minute mineral particles and fragments of siliceous organisms.

No. 70. Station 237, 29th January, 1900.

Lat. $6^{\circ} 11^{\prime} \mathrm{N}$. ; long. $170^{\circ} 25^{\prime} \mathrm{E}$; d depth, 2486 fathoms.

GLOBIGERINA OOZE : brownish gray, coherent, plastic.

Calcium carbonate: 69.35 per cent, pelagic and bottom-living Foraminifera, Echinoid spines, otoliths, Ostracodes, coccoliths, rhabdoliths.

Residue : 30.65 per cent, brown, flocculent:-

Siliceous Organisms (5 per cent), Radiolaria, Sponge spicules.

Minerals ( 1 per cent), angular, mean diameter $0.07 \mathrm{~mm}$., volcanic glass, pumice, felspar (?), augite, magnetite.

Fine Washings (24.65 per cent), amorphous clayey matter, with minute mineral particles and fragments of siliceous organisms.

No. 71. Station 238, 5th February, 1900.

Lat. $5^{\circ} 48^{\prime}$ N. ; long. $169^{\circ} 1^{\prime}$ E. ; depth, 2424 fathoms.

GLOBIGERINA OOZE: gray, coherent, plastic.

Calcium CaRbonate : 74.7 per cent, pelagic and bottom-living Foraminifera, Echinoid spines, otoliths, Ostracodes, coccoliths, rhabdoliths.

REsidue : 25.3 per cent, brown, flocculent :-

Siliceous Organisms (4 per cent), Radiolaria, Sponge spicules.

Minerals ( 1 per cent), angular, mean diameter $0.07 \mathrm{~mm}$., volcanic glass and felspar.

Fine Washings (20.3 per cent), amorphous clayey matter, with minute mineral particles and fragments of siliceous organisms.

No. 72. Station 240, 13th February, 1900.

Lat. $6^{\circ} 49^{\prime}$ N. ; long. $156^{\circ} 36^{\prime}$ E. ; depth, 2475 fathoms.

GLOBIGERINA OOZE: brown, plastic, coherent.

Calcium Carbonate: 62.9 per cent (the mean of two analyses which gave respectively 65.9 and 60 per cent), pelagic and bottom-living Foraminifera (nearly all of which are fragmentary), otoliths, Ostracodes, Echinoid spines, coccoliths, rhabdoliths. 
Residue : 37.1 per cent, brown, flocculent:-

Siliceous Organisms (15 per cent), Radiolaria, Sponge spicules, Diatoms.

Minerals (3 per cent), angular, mean diameter $0.1 \mathrm{~mm}$., pumice (one particle measured $2 \mathrm{~mm}$. in length), volcanic glass, felspar, magnetite.

Fine Washings (19.1 per cent), amorphous clayey matter, with minute mineral particles and fragments of siliceous organisms.

- No. 73. Station 241, 13th February, 1900.

Lat. $6^{\circ} 51^{\prime}$ N. ; long. $154^{\circ} 39^{\prime}$ E. ; depth, 2533 fathoms.

GLOBIGERINA OOZE : brownish gray, plastic, coherent.

Calcium carbonate: 70 per cent, pelagic and bottom-living Foraminifera, Echinoid spines, otoliths, Ostracodes, coccoliths, rhabdoliths.

RESIDUE : 30 per cent, dark brown, flocculent:-

Siliceous Organisms (10 per cent), Radiolaria, Sponge spicules, Diatoms.

Minerals (3 per cent), angular, mean diameter 0.1 mm., pumice, volcanic glass, felspar, magnetite, augite, olivine.

Fine Washings (17 per cent), amorphous clayey matter, with minute mineral particles and fragments of siliceous organisms.

No. 74. Station 243, 15th February, 1900.

Lat. $6^{\circ} 47^{\prime}$ N. ; long. $152^{\circ} 11^{\prime}$ E. ; depth, 2162 fathoms.

GLOBIGERINA OOZE: gray, plastic, coherent.

Calcium carbonate: 72.8 per cent, pelagic and bottom-living Foraminifera, Echinoid spines, Fish teeth and otoliths, Ostracodes, coccoliths, rhabdoliths.

REsidue : 27.2 per cent, reddish brown, flocculent:-

Siliceous Organisms (8 per cent), Radiolaria, Sponge spicules.

Minerals (3 per cent), angular, mean diameter $0.1 \mathrm{~mm}$., pumice (the largest $7 \mathrm{~mm}$. in length), volcanic glass, felspar, magnetite.

Fine Washings (16.2 per cent), amorphous clayey matter, with minute mineral particles and fragments of siliceous organisms.

No. 75. Station 244, 17th February, 1900.

Lat. $8^{\circ} 6^{\prime} \mathrm{N}$.; long. $151^{\circ} 8^{\prime} \mathrm{E}$.; depth, 2205 fathoms.

GLOBIGERINA OOZE : brownish gray, plastic, coherent.

CAlcium CARBonate: 66.6 per cent, pelagic and bottom-living Foraminifera, Echinoid spines, Ostracodes, Fish teeth and otoliths, coccoliths, rhabdoliths. 
THE DEPTH AND MARINE DEPOSITS OF THE PACIFIC OCEAN. 109

RESIDUE : 33.4 per cent, reddish brown, flocculent :-

Siliceous Organisms (10 per cent), Sponge spicules, Radiolaria.

Minerals (5 per cent), angular, mean diameter $0.1 \mathrm{~mm}$, pumice, volcanic glass, plagioclase, augite, olivine, magnetite, chloritic mineral.

Fine Washings (18.4 per cent), amorphous clayey matter, with small mineral particles less than $0.05 \mathrm{~mm}$. in diameter, and splinters of siliceous organisms.

No. 76. Station 245, 18th February, 1900.

Lat. $9^{\circ} 31^{\prime}$ N. ; long. $149^{\circ} 36^{\prime}$ E. ; depth, 2735 fathoms.

RED CLAY : reddish brown, plastic, coherent.

Calcium carbonate: 9.1 per cent (mean of two analyses which gave 9.65 and 8.50 per cent respectively), pelagic Foraminifera (mostly thin and broken), bottom-living Foraminifera, Echinoid spines, Fish teeth.

RESIDUE : 90.9 per cent, reddish brown :-

Siliceous Organisms (2 per cent), Sponge spicules, Radiolaria, arenaceous Foraminifera.

Minerals (5 per cent), angular, mean diameter $0.15 \mathrm{~mm}$., felspar (plagioclase), augite, olivine undergoing decomposition, phillipsite, decomposed volcanic glass, manganese grains, pumice (the largest particle about $2 \mathrm{~mm}$. in length).

Fine Washings ( 83.9 per cent), amorphous clayey matter, with minute mineral particles and fragments of siliceous organisms.

No. 77. Station 246, 19th February, 1900.

Lat. $10^{\circ} 34^{\prime} \mathrm{N}$.; long. $148^{\circ} 25^{\prime} \mathrm{E}$. ; depth, 2993 fathoms.

RED CLAY : chocolate brown, plastic, coherent.

Calcium carbonate: 5 per cent, pelagic Foraminifera.

REsidue : 95 per cent, brown :-

Siliceous Organisms (1 per cent), Sponge spicules, fragments of Radiolaria.

Minerals (10 per cent), angular, mean diameter $0.1 \mathrm{~mm}$., palagonitic substance abundant, decomposed plagioclase, augite, apparently decomposed olivine, manganese grains.

Fine Washings (84 per cent), amorphous clayey matter, with minute mineral particles.

Appended are brief descriptions of those samples which appear to have been subjected to a certain amount of washing during the process of collection, and of one unlabelled sample. 


\section{WASHed SAMPLes.}

Station 24, 14th September, 1899.

Lat. $8^{\circ} 14^{\prime} \mathrm{S}$. ; long. $139^{\circ} 46^{\prime} \mathrm{W}$.; depth, 1040 fathoms.

GLOBIGERINA OOZE : very little material, consisting of the usual pelagic Foraminifera, otoliths, etc., with fragments of manganese nodules, and many small grains of manganese.

Station 25, 14th September, 1899.

Lat. $8^{\circ} 48^{\prime}$ S. ; long. $139^{\circ} 48^{\prime} \mathrm{W}$; ; depth, 830 fathoms.

The material consists of two manganese nodules with palagonitic nuclei, the larger $25 \mathrm{~mm}$. in maximum diameter, along with smaller particles and grains of manganese, mixed with a few pelagic and bottom-living Foraminifera.

Station 26, 14th September, 1899.

Lat. $8^{\circ} 52^{\prime} \mathrm{S}$. ; long. $139^{\circ} 52^{\prime} \mathrm{W}$.; depth, 1173 fathoms.

PTEROPOD OOZE or CORAL MUD : the material does not apparently represent the deposit in situ, being incoherent and fine-grained, consisting of Pteropod fragments, pelagic and bottom-living Foraminifera, Echinoid spines, Ostracodes, Polyzoa, Coral fragments, small shells Mollusc, Serpula, coccoliths; Diatoms, Sponge spicules; with palagonite, much oligoclase (partly decomposed), a little olivine, a bright red mineral, probably decomposition product of olivine, and volcanic glass.

Station 27, 15th September, 1899.

Lat. $9^{\circ} 1^{\prime} \mathrm{S}$. ; long. $140^{\circ} 4^{\prime} \mathrm{W}$.; depth, 687 fathoms.

PTEROPOD OOZE or VOLCANIC MUD: the material has the appearance of having been partly washed, is granular and of a dirty gray color, contains small Pteropods, pelagic and bottom-living Foraminifera, Echinoid spines, Bryozoa, Ostracodes; Sponge spicules, Diatoms; and a great amount of mineral particles (probably 30 per cent of the sample), consisting principally of volcanic glass, felspar, and magnetite. Although apparently washed, a small portion was submitted to analysis, and gave 56.4 per cent of calcium carbonate. 
THE DEPTH AND MARINE DEPOSITS OF THE PACIFIC OCEAN. 111

Station 29, 17th September, 1899.

Lat. $9^{\circ} 16^{\prime} \mathrm{S}$. ; long. $140^{\circ} 25^{\prime} \mathrm{W}$; ; depth, 1932 fathoms.

GLOBIGERINA OOZE: appears to have been washed, is granular, and slightly coherent; pelagic, bottom-living, and arenaceous Foraminifera, coccoliths, rhabdoliths, Sponge spicules.

Minerals (mean diameter $0.07 \mathrm{~mm}$.), augite, olivine (?), plagioclase, magnetite.

Station 30, 18th September, 1899.

Lat. $10^{\circ} 29^{\prime} \mathrm{S}$. ; long. $141^{\circ} 52^{\prime} \mathrm{W}$.; depth, 2456 fathoms.

GLOBIGERINA OOZE: has the appearance of having been washed, is granular and incoherent, dirty brown in color, consisting of broken pelagic Foraminifera, bottom-living Foraminifera, arenaceous Foraminifera, coccoliths, rhabdoliths; Sponge spicules; with volcanic mineral particles, angular, mean diameter $0.1 \mathrm{~mm}$, felspar, obsidian, much magnetite, and plagioclase.

Station 34, 20th September, 1899.

Lat. $14^{\circ} 26^{\prime}$ S. ; long. $146^{\circ} 25^{\prime} \mathrm{W}$; d depth, 1208 fathoms.

GLOBIGERINA OOZE: very little material, which has the appearance of having been washed, cream colored, quite incoherent, consisting of pelagic and bottom-living Foraminifera, Pteropods, Polyzoa, Echinoid spines, fragments of Molluse shells, including one or two small Gasteropod shells (like Pleurotoma), coccoliths, rhabdoliths; arenaceous Foraminifera, Sponge spicules; plagioclase, volcanic glass, and small phillipsite crystals, one or two cosmic spherules.

Station 37, 24th September, 1899.

Avatoru Pass, Paumotu Islands; depth, 112 fathoms.

CORAL SAND : very little material, made up of small fragments of Coral, pelagic Foraminifera, Echinoid spines, small Gasteropods (Pleurotoma), Tunicate spicules; volcanic glass, felspar, magnetite, and grains of manganese.

Station 38, 24th September, 1899.

Avatoru Pass, Paumotu Islands; depth, 604 fathoms.

CORAL SAND: incoherent, white, made up of broken Corals, pelagic Foraminifera, coccoliths, Pteropods, Heteropods, Echinoid spines, small Gasteropods (like Pleurotoma), Ostracodes; small mineral fragments, the largest about $2 \mathrm{~mm}$. in diameter, containing felspar. 
Station 39, 24th September, 1899.

Avatoru Pass, Paumotu Islands; depth, 645 fathoms.

CORAL MUD or PTEROPOD OOZE: white, slightly coherent, finegrained, consisting of broken Corals, Mollusc shells, pelagic and bottomliving Foraminifera, coccoliths, Pteropods, Heteropods (Atlanta, etc.), Echinoid spines.

Station 42, 24th September, 1899.

Avatoru Pass, Paumotu Islands; depth, 661 fathoms.

PTEROPOD OOZE: very little material, which may not represent the deposit in situ, consisting of Pteropods, pelagic and bottom-living Foraminifera, Ostracodes, Mollusc shells, Tunicate spicules, coccoliths, rhabdoliths, etc.

Station 43, 24th September, 1899.

Lat. $15^{\circ} 13^{\prime} \mathrm{S}$. ; long. $147^{\circ} 53^{\prime} \mathrm{W}$.; depth, 341 fathoms.

CORAL SAND : cream color, incoherent, consisting of Coral fragments, Pteropods, Heteropods (Atlanta, etc.), small Gasteropods (Pleurotoma, etc.), Bivalves, and Brachiopods, pelagic and bottom-living Foraminifera, coccoliths, less than 1 per cent of angular mineral particles, mean diameter $0.1 \mathrm{~mm}$., including obsidian and felspar, small cosmic spherule.

Station 44, 24th September, 1899.

Rangiroa, Paumotu Islands; depth, 391 fathoms.

CORAL SAND: cream or gray in color, made up of Coral fragments, Polyzoa, Pteropods, Heteropods (Atlanta, etc.), small Gasteropods, Bivalves, pelagic and bottom-living Foraminifera, coccoliths, and rhabdoliths.

Station 45, 24th September, 1899.

Rangiroa, Paumotu Islands; depth, 524 fathoms.

CORAL SAND: gray, incoherent, fragments of Coral, Polyzoa, Pteropods, Heteropods, small Gasteropods, Echinoid spines, pelagic and bottom-living Foraminifera, coccoliths, rhabdoliths, Tunicate spicules.

Station 46, 24th September, 1899.

Rangiroa, Paumotu Islands; depth, 450 fathoms.

PTEROPOD OOZE or CORAL SAND: gray, incoherent; made up of Coral fragments, Pteropods, Heteropods, Echinoid spines, Polyzoa, Alcyo- 
THE DEPTH AND MARINE DEPOSITS OF THE PACIFIC OCEAN. 113

narian spicules, small Bivalves and Gasteropods, pelagic and bottom-living Foraminifera, coccoliths, rhabdoliths, Tunicate spicules; some of the Foraminifera are coated with manganese.

Station 48, 24th September, 1899.

Between Rangiroa and Tikehau, Paumotu Islands; depth, 897 fathoms.

PTEROPOD OOZE: cream colored with very slight tinge of pink, incoherent; has the appearance of having been slightly washed; Pteropods, Heteropods, pelaric and bottom-living Foraminifera, Echinoid spines, Coral fragments, fragments of Molluscs, with small Gasteropods and Lamellibranchs, Ostracodes, otoliths, coccoliths, rhabdoliths, Tunicate spicules ; small siliceous Sponge spicules, Radiolaria; angular mineral particles, $0.07 \mathrm{~mm}$. in mean diameter, felspar, volcanic glass, manganese grains, and small cinders.

Station 49, 24th September, 1899.

Lat. $15^{\circ} 25^{\prime} \mathrm{S}$; ; long. $148^{\circ} \mathrm{g}^{\prime} \mathrm{W}$.; depth, 1123 fathoms.

GLOBIGERINA OOZE : cream colored, very little material; appears washed; consisting of pelagic and bottom-living Foraminifera, otoliths, coccoliths, rhabdoliths, Tunicate spicules, Pteropods, Echinoid spines, Sponge spicules; only a very few mineral particles were observed.

Station 50, 25th September, 1899.

Lat. $15^{\circ} 25.5^{\prime}$ S. ; long. $148^{\circ} 24.4^{\prime} \mathrm{W}$. ; depth, 1486 fathoms.

GLOBIGERINA OOZE: cream colored, granular; appears washed; pelagic and bottom-living Foraminifera, Echinoid spines, coccoliths, rhabdoliths, Tunicate spicules, arenaceous Foraminifera, Radiolaria, Sponge spicules; no mineral particles observed over $0.04 \mathrm{~mm}$. in diameter.

Station 51, 25th September, 1899.

Lat. $15^{\circ} 2^{\prime}$ S. ; long. $148^{\circ} 24^{\prime}$ W. ; depth, 488 fathoms.

There is so little material from this station that it is impossible to say of what the deposit consists in situ; only one or two calcareous particles were observed.

Station 52, 25th September, 1899.

Lat. $15^{\circ} 1.4^{\prime}$ S. ; long. $148^{\circ} 25^{\prime} \mathrm{W}$. ; depth, 670 fathoms.

CORAL SAND: very little material; gray, incoherent; consisting of broken Corals, Pteropods, Heteropods, pelagic and bottom-living Forami- 
nifera, Echinoid spines, small Gasteropods (Pleurotoma) and Lamellibranchs, Alcyonarian spicules, Tunicate spicules; very little mineral matter.

Station 53, 25th September, 1899.

Off Tikehau, two miles from last position; depth, 782 fathoms.

PTEROPOD OOZE: very little fine material; incoherent, white, granular ; Pteropods, Heteropods, pelagic and bottom-living Foraminifera, Echinoid spines, Polyzoa, Coral fragments, coccoliths, rhabdoliths, Tunicate spicules, Mollusc shells, arenaceous Foraminifera; a few angular mineral particles, mean diametar $0.06 \mathrm{~mm}$., felspar and obsidian; manganese is represented by one or two grains, and it fills the foramina of some of the Foraminifera shells, while a small fragment of Polyzoon was coated with it.

Station 54, 25th September, 1899.

Off Tikehau, three miles from last position; depth, 850 fathoms.

PTEROPOD OOZE: a little material, which has apparently been washed, incoherent, gray, granular; contains many Pteropods, with Heteropods, pelagic and bottom-living Foraminifera, Coral fragments, small Lamellibranchs and Gasteropods (Pleurotoma), Tunicate spicules, coccoliths, rhabdoliths, Echinoid spines, otoliths, Alcyonarian spicules.

Station 55, 25th September, 1899.

Off Tikehau, five miles from last position; depth, 844 fathoms.

PTEROPOD OOZE: incoherent, granular, gray in color; hardly any fine material; Pteropods, Heteropods, pelagic and bottom-living Foraminifera, Echinoid spines, Coral fragments, small Gasteropods (Pleurotoma) and Lamellibranchs, coccoliths, rhabdoliths, Tunicate spicules, Alcyonarian spicules, otoliths; small broken Pleurotoma and some of the Coral fragments and Orbitolites coated with manganese, and one or two grains of manganese were observed; but no other minerals or siliceous organisms were seen.

Station 56, 25th September, 1899.

Lat. $14^{\circ} 56^{\prime}$ S. ; long. $148^{\circ} 44^{\prime}$ W. ; depth, 711 fathoms.

PTEROPOD OOZE: white, granular, incoherent; hardly any fine material, only a few Pteropods, Heteropods, pelagic and bottom-living Foraminifera, Echinoid spines, coccoliths, rhabdoliths, Tunicate spicules, otoliths of Fish, manganese grains, and small fragments of Coral coated with manganese. 
Station 57, 25th September, 1899.

Three miles from last position, north of Matahiva, Paumotu Islands; depth, 486 fathoms.

CORAL SAND : gray, incoherent, granular; has the appearance of having been washed; containing a few Pteropods, Heteropods, pelagic and bottomliving Foraminifera, Alcyonarian spicules, Echinoid spines (some blackened with manganese), Coral fragments, coccoliths, rhabdoliths, otoliths.

Station 58, 25th September, 1899.

Two and a half miles off west shore of Matahiva, Paumotu Islands; depth, 624 fathoms.

CORAL SAND : gray, granular, incoherent; appears to have been washed; consists of Coral and Molluscan-shell fragments, pelagic and bottom-living Foraminifera, otoliths, small Lamellibranchs and Gasteropods (Pleurotoma), Echinoid spines blackened with manganese, Alcyonarian spicules, coccoliths, rhabdoliths, Tunicate spicules.

Station 59, 25th September, 1899.

Four miles off southwest shore of Matahiva, Paumotu Islands; depth, 860 fathoms.

PTEROPOD OOZE or CORAL SAND: gray, incoherent, granular; appears to have been washed; consists of Pteropods, Heteropods, pelagic and bottom-living Foraminifera, Coral fragments (some coated with manganese), otoliths, Echinoid spines, small Gasteropods (Pleurotoma, etc.) and Lamellibranchs, Alcyonarian spicules, coccoliths, rhabdoliths, and Tunicate spicules.

Station 60, 25th September, 1899.

Off south shore of Matahiva, Paumotu Islands; depth, 1257 fathoms.

GLOBIGERINA OOZE: cream colored, granular, incoherent; appears to have been washed; consists of pelagic and bottom-living Foraminifera, Echinoid spines, Alcyonarian spicules, Tunicate spicules, otoliths, small Coral fragments, Polyzoa, Mollusc shells, with small Lamellibranchs and Gasteropods (Pleurotoma), fragments of Pteropods, coccoliths, and rhabdoliths. 
Station 61, 25th September, 1899.

Lat. $15^{\circ} 16^{\prime} \mathrm{S}$. ; long. $148^{\circ} 46^{\prime} \mathrm{W}$; ; depth, 1762 fathoms.

GLOBIGERINA OOZE: incoherent, cream colored, with slight tinge of pink; partly washed; containing pelagic and bottom-living Foraminifera, coccoliths, rhabdoliths, Tunicate spicules.

Station 64, 26th September, 1899.

Lat. $15^{\circ} 51^{\prime}$ S. ; long. $148^{\circ} 15^{\prime} \mathrm{W}$.; depth, 581 fathoms.

CORAL SAND: white, gritty, quite incoherent; may have been washed; consisting of broken Corals, Polyzoa, Echinoid spines, Pteropods, Heteropods, pelagic and bottom-living Foraminifera, Alcyonarian spicules, otoliths, small Gasteropods (Pleurotoma); obsidian fragment $1 \mathrm{~mm}$. in diameter.

Station 65, 26th September, 1899.

Lat. $15^{\circ} 57.3^{\prime} \mathrm{S}$; ; long. $148^{\circ} 18.8^{\prime} \mathrm{W}$.; depth, 1363 fathoms.

CORAL SAND or GLOBIGERINA OOZE: very small quantity of material, which has the appearance of having been washed; it is impossible to state with certainty the type of the deposit in situ. The sample is quite incoherent, gritty, and contains pelagic and bottom-living Foraminifera, fragments of Pteropods and Corals; grains and small concretions of manganese, the largest $2 \mathrm{~mm}$. in diameter, small particles of obsidian.

Station 66, 26th September, 1899.

Lat. $16^{\circ} 10^{\prime} \mathrm{S}$. ; long. $148^{\circ} 26^{\prime} \mathrm{W}$.; depth, 2238 fathoms.

GLOBIGERINA OOZE or RED CLAY : very little material; appears to have been washed; granular, incoherent, and of a brownish gray color; consisting of broken pelagic and bottom-living Foraminifera, Echinoid spines, Pteropod fragments, coccoliths, rhabdoliths; Sponge spicules; manganese grains and concretions.

Station 71, 27th September, 1899.

Lat. $17^{\circ} 25.3^{\prime}$ S. ; long. $149^{\circ} 26^{\prime} \mathrm{W}$.; depth, 775 fathoms.

VOLCANIC MUD: grayish-black, clayey, gritty to the touch; appears to have been partly washed; contains about 20 per cent calcium carbonate, consisting of pelagic and bottom-living Foraminifera, Pteropods, Heteropods (Atlanta), otoliths, Ostracodes, small Lamellibranchs and Gasteropods (Pleurotoma), coccoliths and rhabdoliths, Tunicate spicules; one or two arenaceous 
THE DEPTH AND MARINE DELOSITS OF TIE PACIFIC OCEAN. 117

Foraminifera; mineral particles (probably about 60 per cent), mean diameter $0.3 \mathrm{~mm}$., angular and rounded, augite, magnetite, olivine, dark green chloritic mineral, labradorite, palagonite, and rock fragments.

Station 73, 5th October, 1899.

Lat. $17^{\circ} 27^{\prime} \mathrm{S}$. ; long. $149^{\circ} 32^{\prime} \mathrm{W}$.; depth, 807 fathoms.

VOLCANIC MUD or SAND: gray, fine-grained, quite incoherent; appears to have been washed; contains pelagic and bottom-living Foraminifera, Pteropods, Echinoid spines, Gasteropods (Pleurotoma), Ostracodes, Polyzoa, otoliths, Alcyonarian spicules, Tunicate spicules, coccoliths, rhabdoliths ; angular mineral particles, $0.15 \mathrm{~mm}$. mean diameter obsidian, felspar, augite, magnetite; one or two coprolites observed.

Station 76, 6th October, 1899.

Lat. $15^{\circ} 56.2^{\prime}$ S. ; long. $147^{\circ} 40^{\prime} \mathrm{W}$.; depth, 2269 fathoms.

GLOBIGERINA OOZE: light brown, coherent; very little material, containing about 50 per cent calcium carbonate, which consists of pelagic and bottom-living Foraminifera, mostly fragmentary, small Fish teeth, coccoliths and rhabdoliths ; small mineral particles including obsidian and felspar.

Station 77, 7th October, 1899.

Lat. $16^{\circ} 3^{\prime} \mathrm{S}$; ; long. $147^{\circ} 11^{\prime} \mathrm{W}$.; depth, 1322 fathoms.

GLOBIGERINA OOZE: cream colored, granular, slightly coherent; containing no amorphous clayey matter, but large numbers of small pelagic Foraminifera, bottom-living Foraminifera, Echinoid spines, Coral fragments, otoliths, Ostracodes, fragment of Dentalium, Fish teeth, coccoliths, rhabdoliths, one or two Pteropod fragments, Tunicate spicules, and small calcareous bodies (horseshoe shaped); Radiolaria, Sponge spicules, Diatoms; a very few small mineral particles, including augite and olivine.

Station 78, 7th October, 1899.

Lat. $16^{\circ} 8^{\prime}$ S.; long. $146^{\circ} 42^{\prime}$ W.; depth, 609 fathoms.

PTEROPOD OOZE : cream colored, granular, slightly coherent; very little fine material ; seems to have been washed; contains pelagic and bottom-living Foraminifera, Pteropods, Heteropods, Echinoid spines, small Lamellibranchs and Gasteropods (small Pleurotoma), otoliths, Ostracodes, Fish teeth, coccoliths, rhabdoliths, and Tunicate spicules; Sponge spicules, Radiolaria, Diatoms; obsidian, felspar, and magnetite. 
Station 79, 7th October, 1899.

Lat. $16^{\circ} 10^{\prime} \mathrm{S}$; ; long. $146^{\circ} 23^{\prime} \mathrm{W}$.; depth, 252 fathoms.

CORAL SAND : very little material; coarse-grained and quite incoherent; some of the larger shell fragments blackened by manganese; Coral fragments, Mollusc shells and their fragments, Echinoid-spine fragments, Polyzoa, Serpula, pelagic and bottom-living Foraminifera, Pteropods, Alcyonarian spicules, Tunicate spicules; Sponge spicules, Radiolaria; grains of felspar, the largest attaining a diameter of $0.5 \mathrm{~mm}$.

Station 80, 7th October, 1899.

Lat. $16^{\circ} 11.5^{\prime}$ S.; long. $146^{\circ} 25^{\prime} \mathrm{W}$.; depth, 491 fathoms.

CORAL SAND : very little material ; coarse-grained, incoherent, white ; contains Coral fragments, Polyzoa, Mollusc-shell fragments, with small Lamellibranchs and Gasteropods (Pleurotoma), Echinoid spines, Alcyonarian spicules, otoliths, pelagic and bottom-living Foraminifera, Heteropods (Atlanta), Pteropods; grains of felspar.

Station 81, 7th October, 1899.

Lat. $15^{\circ} 54.5^{\prime}$ S. ; long. $146^{\circ} 20^{\prime} \mathrm{W}$. ; depth, 677 fathoms.

CORAL SAND : fine-grained, incoherent; some of the particles blackened by manganese, fragments of Corals, Polyzoa, Echinoid spines, Gasteropods, Pteropods, pelagic and bottom-living Foraminifera, Ostracodes, Alcyonarian and Tunicate spicules; siliceous Sponge spicules; one or two small grains of felspar.

Station 82, 7 th October, 1899.

Lat. $15^{\circ} 42^{\prime}$ S. ; long. $146^{\circ} 20^{\prime}$ W. ; depth, 675 fathoms.

PTEROPOD OOZE: fine-grained, incoherent, cream colored; appears washed; contains Pteropods, Heteropods, pelagic and bottom-living Foraminifera, Ostracodes, otoliths, Echinoid spines, Coral fragments, fragments of Mollusc shells, with small Lamellibranchs and Gasteropods (Pleurotoma), Tunicate spicules, coccoliths, and rhabdoliths.

Station 83, 7th October, 1899.

Lat. $15^{\circ} 34^{\prime} \mathrm{S}$. ; long. $146^{\circ} 26^{\prime} \mathrm{W}$.; depth, 333 fathoms.

CORAL SAND (?): so little material that it is impossible to state with certainty the character of the deposit in situ; one or two pelagic Foraminifera 
THE DEPTH AND MARINE DEPOSITS OF THE PACIFIC OCEAN. 119 were observed, but what material there is consists principally of Coral fragments; it is probably a Coral Sand.

Station 84, 8th October, 1899.

Lat. $15^{\circ} 35.8^{\prime}$ S. ; long. $146^{\circ} 27.5^{\prime} \mathrm{W}$.; depth, 613 fathoms.

PTEROPOD OOZE : cream colored, granular, quite incoherent; containing Pteropods, Heteropods, pelagic and bottom-living Foraminifera, Molluscshell fragments, with small Gasteropods (Pleurotoma) and Lamellibranchs, Coral fragments, Polyzoa, Echinoid spines, Alcyonarian spicules, Fish teeth, otoliths, Ostracodes, Serpula, Tunicate spicules, coccoliths, and rhabdoliths; fragments of obsidian.

Station 85, 8th October, 1899.

Lat. $15^{\circ} 34.3^{\prime} \mathrm{S}$. ; long. $146^{\circ} 28^{\prime} \mathrm{W}$. ; depth, 520 fathoms.

CORAL SAND : there are only three small fragments of Corals, the largest being 11 by 5 by $3 \mathrm{~mm}$.

Station 86, 8th October, 1899.

Lat. $15^{\circ} 18.3^{\prime}$ S. ; long. $146^{\circ} 23^{\prime} \mathrm{W}$.; depth, 654 fathoms.

CORAL SAND : cream colored, granular, quite incoherent; containing Coral and Polyzoa fragments, pelagic and bottom-living Foraminifera, Pteropods, Heteropods, Echinoid spines, Alcyonarian spicules, Serpula, Ostracodes, Fish teeth, small Lamellibranchs and Gasteropods (Pleurotoma, Voluta), Tunicate spicules, coccoliths, rhabdoliths; and Sponge spicules.

Station 87, 8th October, 1899.

Lat. $15^{\circ} 15^{\prime} \mathrm{S}$. ; long. $146^{\circ} 7^{\prime} \mathrm{W}$; ; depth, 1364 fathoms.

GLOBIGERINA OOZE: cream color, granular, quite incoherent; most of the fine material washed away; consists of pelagic and bottom-living Foraminifera, Echinoid spines, otoliths, Ostracodes, Tunicate spicules, coccoliths, rhabdoliths, small fragments of Polyzoa, the cells of which are filled with manganese, Sponge spicules.

Station 88, 9th October, 1899.

Lat. $14^{\circ} 57^{\prime}$ S. ; long. $144^{\circ} 34^{\prime} \mathrm{W}$.; depth, 360 fathoms.

CORAL SAND: cream colored, granular, quite incoherent; containing Coral fragments, Polyzoa, Mollusc-shell and Echinoid-spine fragments, 


\section{THE DEPTH AND MARINE DEPOSITS OF THE PACIFIC OCEAN.}

Ostracodes, Alcyonarian spicules, otoliths, pelagic and bottom-living Foraminifera, Pteropods, Heteropods, Tunicate spicules, coccoliths, rhabdoliths; Sponge spicules.

Station 89, 14th October, 1899.

Lat. $16^{\circ} 3.5^{\prime}$ S. ; long. $145^{\circ} 43^{\prime} \mathrm{W}$.; depth, 599 fathoms.

PTEROPOD OOZE: cream colored, granular, quite incoherent; containing Pteropods, Heteropods, pelagic and bottom-living Foraminifera, Echinoid fragments and spines, Alcyonarian spicules, otoliths, Ostracodes, Serpula, small Lamellibranchs and Gasteropods, Mollusc-shell and Coral fragments, Tunicate spicules, coccoliths, rhabdoliths; and fragments of obsidian.

Station 90, 14th October, 1899.

Lat. $16^{\circ} 2^{\prime} \mathrm{S}$.; long. $145^{\circ} 43.5^{\prime} \mathrm{W}$.; depth, 666 fathoms.

PTEROPOD OOZE: cream colored, granular, quite incoherent; appears to have been washed; consists of Pteropods, Heteropods, pelagic and bottomliving Foraminifera, Mollusc-shell fragments with small Lamellibranchs and Gasteropods, Coral fragments (some coated with manganese), Polyzoa, Echinoid spines, Alcyonarian spicules, otoliths, Ostracodes, coccoliths, rhabdoliths, Tunicate spicules.

Station 91, 14th October, 1899.

Lat. $16^{\circ} 38^{\prime} \mathrm{S}$. ; long. $145^{\circ} 31^{\prime} \mathrm{W}$.; depth, 602 fathoms.

PTEROPOD OOZE: similar in composition to Station 90, but the remains of the benthonic organisins appear to make up a larger proportion of the deposit.

Station 92, 14th October, 1899.

Lat. $16^{\circ} 44^{\prime} \mathrm{S}$. ; long. $145^{\circ} 35^{\prime} \mathrm{W}$.; depth, 839 fathoms.

Aggregation ( 2 by 2 by $1 \mathrm{~cm}$.) of calcareous deposit (GLOBIGERINA OOZE) coated with manganese. The usual species of pelagic Foraminifera, coccoliths, and rhabdoliths may be observed on rubbing down a little of the internal portion.

Station 93, 14th October, 1899.

Lat. $16^{\circ} 51^{\prime}$ S. ; long. $145^{\circ} 42^{\prime}$ W. ; depth, 1300 fathoms.

GLOBIGERINA OOZE : cream colored, granular, quite incoherent; appears to have been washed; contains pelagic and bottom-living Foraminifera, 
Pteropod fragments, Echinoid spines, Alcyonarian spicules, otoliths, Ostracodes, Tunicate spicules, coccoliths, rhabdoliths; Sponge, spicules; small fragments of obsidian, felspar, and one or two isolated crystals of phillipsite.

Station 95, 15th October, 1899.

Lat. $17^{\circ} 9^{\prime} \mathrm{S}$. ; long. $146^{\circ} 0^{\prime} \mathrm{W}$.; depth, 1079 fathoms.

GLOBIGERINA OOZE: cream colored, granular, quite incoherent; has the appearance of having been washed; contains pelagic and bottom-living Foraminifera (some of the shells coated with manganese), Mollusc-shell fragments, Echinoid spines, otoliths, Tunicate spicules, coccoliths, rhabdoliths; arenaceous Foraminifera, Sponge spicules, Radiolaria.

Station 96, 15th October, 1899.

Lat. $17^{\circ} 14.5^{\prime} \mathrm{S}$. ; long. $145^{\circ} 49^{\prime} \mathrm{W}$.; depth, 527 fathoms.

Fragments of branching Coral, $35 \mathrm{~mm}$. long, blackened with manganese.

Station 97,15 th October, 1899.

Lat. $17^{\circ} 17^{\prime}$ S.; long. $145^{\circ} 45.5^{\prime} \mathrm{W}$.; depth, 804 fathoms.

PTEROPOD OOZE : cream colored, granular, quite incoherent; very little fine material; consists of Pteropods, Heteropods, pelagic and bottom-living Foraminifera, small Gasteropods, Molluse-shell fragments, Coral fragments coated with manganese, otoliths, Ostracodes, Tunicate spicules, coccoliths, rhabdoliths; Sponge spicules, Radiolaria; small fragments of obsidian, pumice, and felspar.

Station 98, 15th October, 1899.

Lat. $17^{\circ} 21^{\prime} \mathrm{S}$. ; long. $145^{\circ} 41^{\prime} \mathrm{W}$.; depth, 642 fathoms.

Very little material, from which it is impossible to state with certainty the nature of the deposit in situ. It consists of fragments of Pteropods, pelagic and bottom-living Foraminifera, otoliths, Mollusc-shell fragments and small Gasteropods (Pleurotoma), Tunicate spicules; small fragments of obsidian, and grains of manganese.

Station 99, 15th October, 1899.

Lat. $17^{\circ} 22^{\prime}$ S. ; long. $145^{\circ} 37^{\prime}$ W.; depth, 568 fathoms.

CORAL SAND : very little material, white, gritty, quite incoherent; consisting of fragments of Corals blackened with manganese, the largest $7 \mathrm{~mm}$. in length, Polyzoa, otoliths, pelagic and bottom-living Foraminifera, Echinoid spines, Pteropods, Heteropods. 
Station 100, 15th October, 1899.

Lat. $17^{\circ} 20^{\prime} \mathrm{S}$. ; long. $145^{\circ} 31^{\prime} \mathrm{W}$.; depth, 225 fathoms.

CORAL SAND: white, gritty, quite incoherent; consisting of Coral and Polyzoa fragments, Echinoid spines, Alcyonarian spicules, pelagic and bottom-living Foraminifera, otoliths, Ostracodes, Pteropods, Heteropods, small Lamellibranchs and Gasteropods, and Tunicate spicules; Sponge spicules; fragments of obsidian and felspar.

Station 101, 15th October, 1899.

Lat. $17^{\circ} 20^{\prime} \mathrm{S}$. ; long. $145^{\circ} 31^{\prime} \mathrm{W}$.; depth, 225 fathoms.

CORAL SAND : cream colored, granular, quite incolierent; has the appearance of having been washed; contains Coral fragments and Mollusc-shell fragments blackened with manganese, the largest being $6 \mathrm{~mm}$. in length, pelagic and bottom-living Foraminifera, small Lamellibranchs and Gasteropods, Pteropod fragments, Heteropods, otoliths, Ostracodes, Echinoid spines, Tunicate spicules, coccoliths, rhabdoliths; Sponge spicules; fragments of obsidian, the largest about $5 \mathrm{~mm}$. in length, and palagonite, highly scoriaceous, the vesicles lined with a purple colored material, and the outside of the pieces black and glassy, coated with manganese, the largest fragment nearly $4 \mathrm{~mm}$. in length.

Station 103, 15th October, 1899.

Lat. $17^{\circ} 3^{\prime} \mathrm{S}$. ; long. $145^{\circ} 8^{\prime} \mathrm{W}$.; depth, 1733 fathoms.

GLOBIGERINA OOZE: cream colored, slightly coherent; appears to have been washed; contains pelagic and bottom-living Foraminifera, Alcyonarian spicules, Ostracodes, otoliths, Tunicate spicules, Pteropod fragments, rhabdoliths, coccoliths; Sponge spicules, Radiolaria, Diatoms; angular mineral particles mean diameter $0.07 \mathrm{~mm}$., magnetite, plagioclase, volcanic glass, decomposed ferro-magnesian mineral.

Station 104, 15th October, 1899.

Lat. $16^{\circ} 55^{\prime}$ S. ; long. $145^{\circ} 3^{\prime} \mathrm{W}$.; depth, 966 fathoms.

GLOBIGERINA OOZE: cream colored, granular, quite incoherent; appears to have been washed; contains pelagic and bottom-living Foraminifera, Pteropods, Heteropods, Echinoid spines, otoliths, Ostracodes, Coral fragments, small Lamellibranchs and Gasteropods, Tunicate spicules, rhabdoliths, coccoliths; Sponge spicules, Radiolaria; angular mineral particles, mean diameter $0.07 \mathrm{~mm}$, consisting of felspar, obsidian, and magnetite. 
Station 105, 15th October, 1899.

Lat. $16^{\circ} 53^{\prime}$ S.; long. $145^{\circ} 0^{\prime} \mathrm{W}$.; depth, 654 fathoms.

CORAL SAND : very little material; black in color, gritty, quite incoherent; consisting of fragments of manganese, the largest about 1 by $2 \mathrm{~mm}$., fragments of Corals, Pteropods, Heteropods, small Gasteropods, pelagic and bottomliving Foraminifera, minute particles of obsidian and felspar.

Station 106, 16th October, 1899.

Lat. $16^{\circ} 55^{\prime} \mathrm{S}$.; long. $144^{\circ} 56^{\prime} \mathrm{W}$.; depth, 269 fathoms.

CORAL SAND : cream colored, gritty, quite incolherent; consisting of Coral fragments, Alcyonarian spicules, Echinoid spines, pelagic and bottom-living Foraminifera, Pteropods, Heteropods, small Gasteropods (Pleurotoma), Serpula.

Station 107, 16th October, 1899.

Lat. $16^{\circ} 24^{\prime} \mathrm{S}$. ; long. $143^{\circ} 59^{\prime} \mathrm{W}$.; depth, 467 fathoms.

CORAL SAND: cream colored, granular, quite incoherent; appears to have been washed; contains Coral and Mollusc-shell fragments, Alcyonarian spicules, Echinoid spines, Ostracodes, otoliths, pelagic and bottom-living Foraminifera, Pteropod fragments, Heteropods, Serpula, one or two Tunicate spicules observed; also small particles of felspar, obsidian, and magnetite.

Station 108, 16th October, 1899.

Lat. $16^{\circ} 20^{\prime} \mathrm{S}$. ; long. $143^{\circ} 55^{\prime} \mathrm{W}$. ; depth, 856 fathoms.

P'TEROPOD OOZE: cream colored, granular, slightly coherent; appears to have been washed; consists of Pteropods, Heteropods, pelagic and bottomliving Foraminifera, Alcyonarian spicules, Echinoid spines, Ostracodes, otoliths, small Lamellibranchs and Gasteropods, Serpula, Coral fragments; a few grains of plagioclase, oligoclase, sanidine, magnetite, and volcanic glass (but no ferro-magnesian minerals) were observed.

Station 110, 16th October, 1899.

Lat. $16^{\circ} 3^{\prime} \mathrm{S}$. ; long. $143^{\circ} 32^{\prime} \mathrm{W}$. ; depth, 1084 fathoms.

GLOBIGERINA OOZE : cream colored with tinge of pink, granular, quite incoherent; has the appearance of having been partly washed; consists of pelagic and bottom-living Foraminifera, Pteropods, otoliths, Ostracodes, Echinoid spines, small Lamellibranchs and Gasteropods, Tunicate spicules, coccoliths, rhabdoliths; Sponge spicules, Radiolaria; one or two fragments 


\section{THE DEPTH AND MARINE DEPOSITS OF THE PACIFIC OCEAN.}

of obsidian about $1 \mathrm{~mm}$. in length, and minute particles of felspar and magnetite were observed.

Station 111, 17 th October, 1899.

Lat. $15^{\circ} 53^{\prime}$ S. ; long. $143^{\circ} 26^{\prime} \mathrm{W}$.; depth, 1805 fathoms.

GLOBIGERINA OOZE: cream colored, granular; appears to have been washed; contains pelagic and bottom-living Foraminifera, Ostracodes, otoliths, Tunicate spicules, coccoliths, rhabdoliths; arenaceous Foraminifera; minute particles of obsidian observed.

Station 112, 17th October, 1899.

Lat. $15^{\circ} 54^{\prime} \mathrm{S}$. ; long. $143^{\circ} 6^{\prime} \mathrm{W}$.; depth, 1568 fathoms.

GLOBIGERINA OOZE: cream colored, granular; appears to have been washed; contains pelagic and bottom-living Foraminifera, Ostracodes, otoliths, Echinoid spines, Tunicate spicules, coccoliths, rhabdoliths; small particles of obsidian.

Station 114, 17th October, 1899.

Lat. $15^{\circ} 56^{\prime} \mathrm{S}$; ; long. $142^{\circ} 29^{\prime} \mathrm{W}$.; depth, 1385 fathoms.

GLOBIGERINA OOZE: cream colored with a tinge of pink, fine-grained, incoherent; appears to have been partly washed; contains pelagic and bottom-living Foraminifera, Echinoid spines, otoliths, Ostracodes, Coral fragments, Tunicate spicules, coccoliths, rhabdoliths; Radiolaria, Sponge spicules; minute mineral particles consisting of felspar, obsidian, and magnetite.

Station 115, 17th October, 1899.

Lat. $15^{\circ} 56.3^{\prime}$ S. ; long. $142^{\circ} 29^{\prime}$ W.; depth, 508 fathoms.

CORAL SAND: cream colored, gritty, very little material, quite incoherent; has the appearance of having been washed; consists of Coral fragments, Echinoid spines, Alcyonarian spicules, pelagic and bottom-living Foraminifera, Pteropods, Heteropods, Molluse-shell fragments with small Gasteropods and Lamellibranchs, otoliths, Ostracodes ; particles of obsidian.

Station 116, 18th October, 1899.

Lat. $15^{\circ} 53^{\prime}$ S. ; long. $142^{\circ} 14^{\prime} \mathrm{W}$.; depth, 572 fathoms.

CORAL SAND : gray colored, coarse-grained, gritty, quite incoherent; no fine material; appears to have been washed; contains Coral fragments, 
THE DEPTH AND MARINE DEPOSITS OF THE PACIFIC OCEAN. 125

Echinoid fragments and spines, Alcyonarian spicules, small Gasteropods and Lamellibranchs, otoliths, Ostracodes, pelagic and bottom-living Foraminifera, Pteropod fragments, Heteropod fragments, Polyzoa; small particles of obsidian were observed.

Station 117, 18th October, 1899.

Lat. $15^{\circ} 54^{\prime} \mathrm{S}$. ; long. $142^{\circ} 16^{\prime} \mathrm{W}$.; depth, 563 fathoms.

Only one or two small fragments of decomposed pumice, coated with manganese, were at hand, the largest being about $2 \mathrm{~mm}$. in length, also some calcareous grains, which look like Coral fragments.

Station 118, 18th October, 1899.

Lat. $16^{\circ} 12^{\prime} \mathrm{S}$. ; long. $142^{\circ} 31^{\prime} \mathrm{W}$.; depth, 630 fathoms.

CORAL SAND : gray, granular, quite incoherent; appears to have been washed; consists of fragments of Corals, Polyzoa, small Lamellibranchs and Gasteropods, otoliths, Ostracodes, pelagic and bottom-living Foraminifera, Pteropods, Heteropods, Echinoid spines, Alcyonarian spicules, Tunicate spicules; small particles of obsidian and magnetite were observed.

Station 119, 18th October, 1899.

Lat. $16^{\circ} 14^{\prime} \mathrm{S}$. ; long. $142^{\circ} 50^{\prime} \mathrm{W}$; ; depth, 1516 fathoms.

GLOBIGERINA OOZE : cream colored, granular, quite incoherent; appears to have been washed; consists of pelagic and bottom-living Foraminifera, otoliths, Ostracodes, Tunicate spicules, coccoliths, rhabdoliths; minute particles of obsidian and magnetite were observed.

Station 120, 18th October, 1899.

Lat. $16^{\circ} 21^{\prime}$ S. ; long. $143^{\circ} 14^{\prime} \mathrm{W}$.; depth, 928 fathoms.

CORAL SAND or PTEROPOD OOZE: very little material ; cream colored, granular, quite incoherent; appears to have been washed; contains Coral fragments, Polyzoa, Pteropods, Heteropods, pelagic and bottom-living Foraminifera, Ostracodes, otoliths, Tunicate spicules; small particles of obsidian and magnetite.

Station 121, 19th October, 1899.

Lat. $16^{\circ} 25^{\prime}$ S. ; long. $143^{\circ} 33^{\prime} \mathrm{W}$.; depth, 1108 fathoms.

PTEROPOD OOZE : very little material; granular, cream colored, incoherent; has the appearance of having been washed; consists of Pteropods, 
Heteropods, pelagic and bottom-living Foraminifera, Echinoid spines, otoliths, Ostracodes, Tunicate spicules, coccoliths, rhabdoliths; a few minute particles of obsidian were observed.

Station 122, 20th October, 1899.

Lat. $16^{\circ} 29^{\prime}$ S. ; long. $143^{\circ} 41^{\prime} \mathrm{W}$.; depth, 540 fathoms.

CORAL SAND : very little material; cream colored; appears to have been washed; consists of Coral fragments, Echinoid spines, Alcyonarian spicules, otoliths, Ostracodes, small Lamellibranchs and Gasteropods, Pteropods, Heteropods, pelagic and bottom-living Foraminifera, Polyzoa, Tunicate spicules; minute particles of obsidian were observed.

Station 123, 25th October, 1899.

Lat. $16^{\circ} 35^{\prime} \mathrm{S}$; ; long. $143^{\circ} 31^{\prime} \mathrm{W}$.; depth, 603 fathoms.

CORAL SAND : gray, gritty, quite incoherent; containing Coral fragments, the largest 9 by 6 by $4 \mathrm{~mm}$., Alcyonarian spicules, small Lamellibranchs and Gasteropods, Echinoid spines, otoliths, Ostracodes, Pteropods, Heteropods, pelagic and bottom-living Foraminifera, Tunicate spicules ; small particles of obsidian.

Station 124, 25th October, 1899.

Lat. $16^{\circ} 42^{\prime} \mathrm{S}$. ; long. $143^{\circ} 10^{\prime} \mathrm{W}$.; depth, 1221 fathoms.

GLOBIGERINA OOZE: gray, spotted with black (manganese), granular, quite incoherent, very little material; appears to have been washed; contains pelagic and bottom-living Foraminifera, Pteropod fragments, Heteropod fragments; grains of manganese and small particles of obsidian were observed.

Station 125, 26th October, 1899.

Lat. $17^{\circ} 7^{\prime} \mathrm{S}$; ; long. $142^{\circ} 49^{\prime} \mathrm{W}$.; depth, 1235 fathoms.

GLOBIGERINA OOZE : cream colored, fine-grained, incoherent; appears to have been washed; consists of pelagic and bottom-living Foraminifera, Pteropods, Heteropods, Ostracodes, otoliths, Echinoid spines, Tunicate spicules, coccoliths, rhabdoliths; Sponge Spicules, Radiolaria; minute particles of felspar, obsidian, and magnetite.

Station 126, 26th October, 1899.

Lat. $17^{\circ} 7^{\prime}$ S. ; long. $142^{\circ} 49^{\prime} \mathrm{W}$.; depth, 1235 fathoms.

GLOBIGERINA OOZE: dirty cream colored, granular, incoherent; has the appearance of having been washed; contains pelagic and bottom-living 
THE DEPTH AND MARINE DEPOSITS OF THE PACIFIC OCEAN. 127

Foraminifera, Echinoid spines, otoliths, Ostracodes, small Gasteropods, Tunicate spicules, coccoliths, rhabdoliths; minute particles of obsidian, felspar, and magnetite.

Station 127, 26th October, 1899.

Lat. $17^{\circ} 20^{\prime}$ S. ; long. $142^{\circ} 35^{\prime} \mathrm{W}$; ; depth, 617 fathoms.

PTEROPOD OOZE: cream colored, fine-grained, incoherent; appears to have been washed; consists of Pteropods, Heteropods, pelagic and bottomliving Foraminifera, small Lamellibranchs and Gasteropods, otoliths, Ostracodes, Tunicate spicules, rhabdoliths, coccoliths; small particles of felspar, obsidian, and magnetite.

Station 129, 27th October, 1899.

Lat. $17^{\circ} 35^{\prime} \mathrm{S}$.; long. $142^{\circ} 42^{\prime} \mathrm{W}$; ; depth, 348 fathoms.

CORAL SAND: cream colored, granular, incoherent; contains Coral fragments, Alcyonarian spicules, Echinoid spines, Pteropod fragments, Heteropods, otoliths, Ostracodes, pelagic and bottom-living Foraminifera, Polyzoa, Tunicate spicules; minute particles of obsidian were observed.

Station 130, 27th October, 1899.

Lat. $17^{\circ} 35^{\prime} \mathrm{S}$; ; long. $142^{\circ} 44^{\prime} \mathrm{W}$.; depth, 798 fathoms.

CORAL SAND or PTEROPOD OOZE: cream colored, granular, incoherent; appears to have been washed; contains Coral fragments, Pteropods, Heteropods, Polyzoa, otoliths, Ostracodes, Alcyonarian spicules, Echinoid spines, small Lamellibranchs and Gasteropods, pelagic and bottom-living Foraminifera, Tunicate spicules; one or two minute particles of felspar and obsidian observed.

Station 131, 28th October, 1899.

Lat. $17^{\circ} 47^{\prime}$ S.; long. $142^{\circ} 29^{\prime} \mathrm{W}$.; depth, 1372 fathoms.

GLOBIGERINA OOZE: cream colored, fine-grained, slightly coherent; appears to have been washed; contains pelagic and bottom-living Foraminifera, Pteropods, Heteropods, otoliths, Ostracodes, small Lamellibranchs, Tunicate spicules, rhabdoliths, coccoliths; Sponge spicules; minute particles of felspar and obsidian. 
Station 132, 28th October, 1899.

Lat. $18^{\circ} 0^{\prime}$ S. ; long. $142^{\circ} 29^{\prime}$ W.; depth, 1620 fathoms.

GLOBIGERINA OOZE: cream colored, granular, incoherent; appears to have been washed; contains pelagic and bottom-living Foraminifera, small Lamellibranchs, otoliths, Ostracodes, Tunicate spicules, coccoliths, rhabdoliths; small particles of obsidian, felspar, and magnetite.

Station 133, 28th October, 1899.

Lat. $18^{\circ} 5^{\prime} \mathrm{S}$. ; long. $142^{\circ} 23^{\prime} \mathrm{W}$.; depth, 742 fathoms.

GLOBIGERINA OOZE or CORAL SAND: very little material, from which it is impossible to state the type of deposit with certainty; cream colored with black grains (manganese), granular, quite incoherent; appears to have been washed; no fine amorphous clayey matter; consists of pelagic and bottom-living Foraminifera, Pteropods, Heteropods, Echinoid spines, otoliths, Ostracodes, Coral fragments coated with manganese; particles of obsidian and magnetite, mostly angular, mean diameter $0.1 \mathrm{~mm}$.

From this station the following specimens were taken by the trawl:-

(1) Small branch of tree, about two inches long, rotten, and impregnated with manganese; small strips of bark, one showing leaf seat; small piece of charred wood.

(2) Piece of anthracite, angular, clean, showing conchoidal fracture in places, glistening, $2 \frac{3}{4}$ by 2 by 1 inches.

(3) Piece of coral-rock, showing structure of Coral clearly, 2 by $1 \frac{1}{4}$ by 1 inches, perfectly blackened inside and outside with manganese.

(4) Flat oblong rounded piece of coral-rock or calcareous material, showing no structure of Coral, $1 \frac{3}{4}$ by $\frac{1}{8}$ inches, blackened by manganese and impregnated with it; full of vesicular cavities containing very fresh and perfectly white pelagic Foraminifera, Pteropods, and Heteropods.

(5) Flat rounded piece of calcareous material, same as above, $\frac{3}{4}$ by $\frac{1}{5}$ inches.

(6) Flat oblong angular piece of calcareous material, same as above, 1 by $\frac{5}{8}$ by $\frac{1}{4}$ inches.

(7) Rounded piece of soft white chalky calcareous rock, $\frac{1}{2}$ by $\frac{1}{4}$ inches, consisting of coccoliths, rhabdoliths, and fine amorphous calcareous matter.

(8) Three angular furnace cinders, the largest being 3 by 1 by $\frac{1}{2}$ inches. 
THE DEPTH AND MARINE DEPOSITS OF THE PACIFIC OCEAN. 129

(9) Oblong flat piece of yellowish colored clay, 22 by 11 by $7 \mathrm{~mm}$., compact, fine-grained, can be scratched with the finger-nail, spotted on all sides with imperfect dendrites of manganese, edges angular, somewhat brick shaped with a slight bend, not unlike a piece of decomposed earthenware; contains in its argillaceous ground-mass fibrous glassy particles and undeterminable crystalline particles.

Station 134, 28th October, 1899.

Lat. $18^{\circ} 6^{\prime}$ S. ; long. $142^{\circ} 24^{\prime}$ W. ; depth, 807 fathoms.

CORAL SAND or PTEROPOD OOZE: cream colored, with blackened Coral fragments, granular, incoherent; appears to have been washed; consists of Coral fragments, Pteropods, Heteropods, pelagic and bottom-living Foraminifera, otoliths, Ostracodes, Echinoid spines, Mollusc-shell fragments, small Lamellibranchs and Gasteropods, Tunicate spicules, rhabdoliths, coccoliths; Sponge spicules, Radiolaria ; obsidian, plagioclase, and other felspars, manganese grains.

From this station were also obtained some Coral fragments blackened with manganese, small cinders, fragments of calcareous matter coated with manganese, similar to specimens (4) to (6) at Station 133, and a piece of what appears to be consolidated ooze, about $\frac{1}{2}$ inch in diameter, made up of pelagic Foraminifera, etc. ; also a piece of anthracite, flat, almost rectangular, 12 by 9 by 2 mm., similar to specimen (2) at Station 133.

Station 135, 28th October, 1899.

Pass between Marokau and Ravahere, Paumotu Islands; depth, 278 fathoms.

Very little material, from which it is impossible to state the type of deposit in situ, consisting of grains of Coral coated with manganese, the largest being 6 by $1 \mathrm{~mm}$; one or two pelagic Foraminifera (Globigerina).

Station 137, 29th October, 1899.

Lat. $18^{\circ} 7^{\prime} \mathrm{S}$. ; long. $141^{\circ} 26^{\prime}$ W. ; depth, 1713 fathoms.

GLOBIGERINA OOZE: cream colored, granular, quite incoherent; appears to have been washed; consists of pelagic and bottom-living Foraminifera, Ostracodes, coccoliths, rhabdoliths; Sponge spicules, Radiolaria; minute particles of felspar, obsidian, and magnetite. 
Station 138, 29th October, 1899.

Lat. $18^{\circ} 5^{\prime}$ S. ; long. $141^{\circ} 3^{\prime} \mathrm{W}$.; depth, 425 fathoms.

CORAL SAND: cream colored, quite incoherent; containing Coral fragments, Echinoid spines, Alcyonarian spicules, otoliths, Ostracodes, pelagic and bottom-living Foraminifera, Heteropods, small Lamellibranchs and Gasteropods, Tunicate spicules; Sponge spicules; one or two minute particles of obsidian and felspar.

Station 139, 29th October, 1899.

Lat. $18^{\circ} 8^{\prime} \mathrm{S}$. ; long. $141^{\circ} 4^{\prime} \mathrm{W}$.; depth, 812 fathoms.

CORAL SAND: cream colored, quite incoherent; containing Coral fragments, Echinoid spines, Alcyonarian spicules, otoliths, Ostracodes, pelagic Foraminifera, Heteropods, Tunicate spicules, Mollusc-shell fragments, and small Gasteropods; no mineral particles observed.

Station 141, 30th October, 1899.

Lat. $18^{\circ} 29^{\prime}$ S. ; long. $139^{\circ} 53^{\prime} \mathrm{W}$.; depth, 1490 fathoms.

GLOBIGERINA OOZE: cream colored, granular, incoherent; appears to have been washed; contains pelagic and bottom-living Foraminifera, Echinoid spines, otoliths, Ostracodes, coccoliths, rhabdoliths; Sponge spicules; minute mineral particles (very scarce), volcanic glass, decomposed ferromagnesian mineral, and manganese grains.

Station 143, 30th October, 1899.

Lat. $18^{\circ} 34^{\prime}$ S. ; long. $139^{\circ} 19^{\prime}$ W.; depth, 1364 fathoms.

GLOBIGERINA OOZE: gray with black grains, very little material, granular, incoherent; appears to have been washed; contains pelagic and bottom-living Foraminifera, coccoliths, rhabdoliths; minute mineral particles consisting of obsidian, magnetite, and grains of manganese.

Station 144, 30th October, 1899.

Lat. $18^{\circ} 30^{\prime}$ S.; long. $139^{\circ} 15^{\prime} \mathrm{W}$. ; depth, 377 fathoms.

CORAL SAND : cream colored, gritty, incoherent; appears to have been washed; contains Coral fragments, Echinoid spines, Alcyonarian spicules, otoliths, Ostracodes, pelagic and bottom-living Foraminifera, small Gastero- 
THE DEPTH AND MARINE DEPOSITS OF THE PACIFIC OCEAN. 131

pods and Lamellibranchs, Heteropods, Pteropods, Tunicate spicules; minuto particles of felspar, obsidian, magnetite, and manganese.

Station 145, 30th October, 1899.

Lat. $18^{\circ} 36^{\prime}$ S. ; long. $139^{\circ} 14^{\prime}$ W. ; depth, 1725 fathoms.

GLOBIGERINA OOZE : cream colored, granular, incoherent; has the appearance of having been.washed; contains Coral fraginents, pelagic and bottom-living Foraminifera, otoliths, Ostracodes, Echinoid spines, Pteropods, Mollusc-shell fragments, Tunicate spicules; minute particles of obsidian observed.

Station 147, 31st October, 1899.

Lat. $19^{\circ} 17^{\prime}$ S. ; long. $138^{\circ} 54^{\prime} \mathrm{W}$.; depth, 1688 fathoms.

GLOBIGERINA OOZE: cream colored with black grains (manganese), granular, incoherent; appears to have been washed; contains pelagic For:minifera and one or two bottom-living forms; the manganese particles vary from the merest grains up to $5 \mathrm{~mm}$. in diameter, and many of them have a brilliant black shining fracture, with mammillated external portions.

Station 148, 31st October, 1899.

Lat. $19^{\circ} 16^{\prime}$ S. ; long. $138^{\circ} 49^{\prime}$ W. ; depth, 636 fathoms.

PTEROPOD OOZE or CORAL SAND: cream colored, granular, incoherent; appears to have been washed; consists of Coral fragments, Pteropods, Heteropods, pelagic and bottom-living Foraminifera, Alcyonarian spicules, Echinoid spines, otoliths, Ostracodes, Tunicate spicules; minute particles of obsidian and grains of manganese observed.

Station 149, 31st October, 1899.

Lat. $19^{\circ} 23.5^{\prime}$ S. ; long. $138^{\circ} 46^{\prime} \mathrm{W}$.; depth, 860 fathoms.

GLOBIGERINA OOZE (?) : very little material, consisting of pelagic Foraminifera, with grains and particles of manganese.

Station 150, 31st October, 1899.

Lat. $19^{\circ} 27.5^{\prime}$ S. ; long. $138^{\circ} 44^{\prime}$ W. ; depth, 486 fathoms.

CORAL SAND : incoherent; consisting of fragments of Corals, Molluses, Pteropods, Heteropods, pelagic and bottom-living Foraminifera, Echinoid spines, Alcyonurian and Sponge spicules, etc. 
Station 153, 1st November, 1899.

Lat. $19^{\circ} 45.5^{\prime}$ S. ; long. $139^{\circ} 54^{\prime}$ W. ; depth, 1494 fathoms.

GLOBIGERINA OOZE with manganese: very little material, apparently washed, consisting of pelagic Foraminifera, Ostracodes, etc., mixed with many grains and fragments of manganese, the largest attaining a diameter of $3 \mathrm{~mm}$., with black shining fracture.

Station 154, 1st November, 1899.

Lat. $19^{\circ} 52^{\prime} \mathrm{S}$. ; long. $140^{\circ} 16^{\prime} \mathrm{W}$.; depth, 2284 fathoms.

RED CLAY : small quantity of material, yellowish brown in color, clayey; consisting of pelagic Foraminifera, Echinoid spines, bottom-living Foraminifera, Fish teeth, coccoliths, rhabdoliths; residue dark brown, many grains and particles of manganese (one $4 \mathrm{~mm}$. in diameter), phillipsite, felspar, volcanic glass, etc. A very small portion of the sample gave 24.5 per cent calcium carbonate, but the material available is quite inadequate for a detailed description.

Station 155, 1st November, 1899.

Lat. $20^{\circ} 7^{\prime}$ S. ; long. $141^{\circ} 0^{\prime} \mathrm{W}$.; depth, 2391 fathoms.

Half a dozen small grains of manganese, the largest $2 \mathrm{~mm}$. in diameter.

Station 158, 2nd November, 1899.

Lat. $20^{\circ} 43^{\prime}$ S. ; long. $143^{\circ} 5^{\prime} \mathrm{W}$.; depth, 649 fathoms.

CORAL SAND: very little material, apparently washed; consisting of Coral fragments, Polyzoa, Pteropods, Heteropods, pelagic and bottom-living Foraminifera, otoliths, Alcyonarian spicules, Echinoid fragments and spines, Mollusc-shell fragments, Tunicate spicules; Sponge spicules.

Station 159, 2nd November, 1899.

Lat. $20^{\circ} 42^{\prime}$ S.; long. $143^{\circ} 3^{\prime} \mathrm{W}$.; depth, 736 fathoms.

CORAL SAND: the material is quite incoherent; probably washed; consisting of Coral fragments (the largest $13 \mathrm{~mm}$. in diameter), pelagic and bottom-living Foraminifera, Pteropods, Heteropods, and other Molluscs, Polyzoa, Echinoid spines, otoliths, Alcyonarian spicules, Serpula tubes; Sponge spicules. 
Station 160, 2nd November, 1899.

Lat. $20^{\circ} 40^{\prime}$ S. ; long. $143^{\circ} 9^{\prime} \mathrm{W}$.; depth, 1609 fathoms.

GLOBIGERINA OOZE: very little material, incoherent; consisting of Coral fragments, pelagic and bottom-living Foraminifera, Alcyonarian spicules, Pteropods and other Molluses, Echinoid spines; Sponge spicules; and many manganese grains (one or two $2 \mathrm{~mm}$. in diameter).

Station 161, 2nd November, 1899.

Lat. $20^{\circ} 3 \tau^{\prime} \mathrm{S}$. ; long. $143^{\circ} 15^{\prime} \mathrm{W}$.; depth, 574 fathoms.

PTEROPOD OOZE (?): the material is incoherent, consisting principally of Pteropods, Heteropods, and their fragments, with Coral fragments, pelagic and bottom-living Foraminifera, otoliths, Alcyonarian spicules, Molluse fragments, Tunicate spicules, coccoliths, and rhabdoliths.

Station 162, 2nd November, 1899.

Lat. $20^{\circ} 37^{\prime} \mathrm{S}$. ; long. $143^{\circ} 18^{\prime} \mathrm{W}$.; depth, 659 fathoms.

PTEROPOD OOZE or CORAL SAND: very little material, incoherent, consisting of Coral fragments, Pteropods, Heteropods, pelagic and bottomliving Foraminifera, Molluscs, Echinoid spines, coccoliths, rhabdoliths, etc.

Station 163, 2nd November, 1899.

Lat. $20^{\circ} 34^{\prime} \mathrm{S}$; ; long. $143^{\circ} 23^{\prime} \mathrm{W}$.; depth, 1890 fathoms.

GLOBIGERINA OOZE : the material is incoherent and very fine-grained, consisting principally of minute pelagic Foraminifera, along with a small proportion of larger specimens, bottom-living Foraminifera, Echinoid spines, coccoliths, and rhabdoliths.

Station 164, 2nd November, 1899.

Lat. $20^{\circ} 29^{\prime}$ S. ; long. $143^{\circ} 29^{\prime}$ W. ; depth, 438 fathoms.

CORAL SAND : very little material, consisting of Coral fragments, Polyzoa, Pteropods and Heteropods and other Molluses, bottom-living Foraminifera, one or two pelagic Foraminifera, Alcyonarian spicules, Tunicate spicules, coccoliths, rhabdoliths, etc. Polytrema rubra is very abundant, giving a pink tinge to the otherwise white material. 
Station 165, 2nd November, 1899.

Lat. $20^{\circ} 27^{\prime}$ S. ; long. $143^{\circ} 32^{\prime} \mathrm{W}$. ; depth, 406 fathoms.

CORAL SAND: very little material, consisting of Coral fragments, Pteropods and Heteropods and other Molluses, pelagic and bottom-living Foraminifera, Alcyonarian spicules, Echinoid spines, Tunicate spicules, coccoliths, and rhabdoliths.

Station 166, 2nd November, 1899.

Lat. $20^{\circ} 15^{\prime} \mathrm{S}$. ; long. $144^{\circ} 0^{\prime} \mathrm{W}$.; depth, 2265 fathoms.

GLOBIGERINA OOZE or RED CLAY : little material, which does not apparently represent the deposit in situ; containing pelagic and bottom-living Foraminifera, crystalline calcareous particles (dolomitic limestone), coccoliths, rhabdoliths, and other calcareons bodies (horse-shoe shaped); with many manganese grains and nodules, the largest $10 \mathrm{~mm}$. in diameter, consisting of volcanic glass in various stages of decomposition impregnated and coated with manganese. Some of the volcanic glass fragments are entirely converted into palagonite of a brilliant red color, others greenish, and one nodule quite white internally was composed of unaltered volcanic glass with a thin covering of manganese; some are free from manganese, and others only slightly blackened; phillipsite in twins and isolated crystals was also observed.

Station 168, 3rd November, 1899.

Lat. $19^{\circ} 54^{\prime}$ S. ; long. $144^{\circ} 48^{\prime} \mathrm{W}$.; depth, 1719 fathoms.

GLOBIGERINA OOZE: very little material, apparently washed; consisting almost entirely of pelagic Foraminifera, a large proportion of small size, with one or two bottom-living forms, coccoliths, and rhabdoliths.

Station 169, 3rd November, 1899.

Lat. $19^{\circ} 54^{\prime} \mathrm{S}$. ; long. $144^{\circ} 53^{\prime} \mathrm{W}$. ; depth, 594 fathoms.

CORAL SAND : very little material, apparently washed, consisting of Coral fragments, Pteropods and Heteropods and other Molluses, pelagic and bottom-living Foraminifera, Echinoid spines, Polyzoa, Serpula, etc.

Station 170, 3rd November, 1899.

Lat. $19^{\circ} 54^{\prime} \mathrm{S}$. ; long. $144^{\circ} 59^{\prime} \mathrm{W}$.; depth, 189 fathoms.

CORAL SAND : very little material, apparently washed, consisting of Coral fragments, Pteropods and other Molluscs, pelagic and bottom-living Foraminifera, etc.; several particles of iron rust, evidently from sounding machine. 
Station 171, 3rd November, 1899.

Lat. $19^{\circ} 50^{\prime} \mathrm{S}$. ; long. $145^{\circ} 3^{\prime} \mathrm{W}$.; depth, 1688 fathoms.

GLOBIGERINA OOZE: little material, principally pelagic Foraminifera, large proportion of small size, bottom-living Foraminifera, Echinoid spines, otoliths, coccoliths, rhabdoliths, etc., with many Coral fragments, the largest $12 \mathrm{~mm}$. in diameter, some of them colored brown on the outside. This deposit is remarkable for the large amount of fine calcareous matter (coccoliths, rhabdoliths, primordial cells of Foraminifera, and very small pelagic Foraminifera) associated with such large fragments from the reefs.

Station 175, 5th November, 1899.

Lat. $18^{\circ} 3^{\prime} \mathrm{S}$. ; long. $147^{\circ} 48^{\prime} \mathrm{W}$.; depth, 2129 fathoms.

VOLCANIC MUD (?): little material, apparently washed, consisting almost entirely of splinters of recent volcanic glass, with a few pelagic and bottomliving Foraminifera, coccoliths, and rhabdoliths.

Station 176, 5th November, 1899.

Lat. $17^{\circ} 54^{\prime} \mathrm{S}$; ; long. $148^{\circ} 0^{\prime} \mathrm{W}$.; depth, 832 fathoms.

CORAL SAND or VOLCANIC MUD: little material, apparently washed, consisting of calcareous fragments and volcanic mineral particles in about equal proportions; the following were observed: pelagic and bottomliving Foraminifera, Pteropods and other Molluses and their fragments, Aleyonarian spicules, Corals, Serpula, Echinoid spines; volcanic glass, palagonite, felspar, magnetite, etc.

Station 177,5 th November, 1899.

Lat. $17^{\circ} 51^{\prime}$ S. ; long. $148^{\circ} 3^{\prime} \mathrm{W}$.; depth, 142 fathoms.

A few fragments of vesicular volcanic rock, the largest $10 \mathrm{~mm}$. in diameter, with one or two calcareous fragments (Molluscs, Corals, bottom-living Foraminifera).

Station 178, 5th November, 1899.

Lat. $17^{\circ} 46^{\prime}$ S. ; long. $148^{\circ} 23^{\prime} \mathrm{W}$.; depth, 2111 fathoms.

VOLCANIC MUD: little material, apparently washed, consisting almost entirely of small splinters of recent vesicular volcanic glass, with a few pelagic Foraminifera. 
Station 179, 5th November, 1899.

Lat. $17^{\circ} 35^{\prime}$ S. ; long. $148^{\circ} 48^{\prime} \mathrm{W}$.; de pth, 1755 fathoms.

VOLCANIC MUD: not much material, black with white specks; like the material from last station.

Station 180, 15th November, 1899.

Lat. $17^{\circ} 30^{\prime}$ S.; long. $149^{\circ} 41^{\prime} \mathrm{W}$.; depth, 981 fathoms.

VOLCANIC MUD: gritty, fine-grained, incoherent; has the appearance of having been washed; contains pelagic and bottom-living Foraminifera, Echinoid spines, Polyzoa, small Mollusc shells, Pteropods, Heteropods; minerals abundant, angular, mean diameter $0.1 \mathrm{~mm}$, augite, palagonitic matter, olivine, plagioclase, chloritic mineral, biotite, much magnetite.

Station 183, 24th November, 1899.

Lat. $19^{\circ} 4^{\prime} \mathrm{S}$. ; long. $167^{\circ} 41^{\prime} \mathrm{W}$.; depth, 2472 fathoms.

RED CLAY : very little material, incoherent, apparently washed, consisting of angular mineral particles, mean diameter $0.1 \mathrm{~mm}$., felspar, obsidian, pumice, magnetite, and manganese, small rock particles about $1 \mathrm{~mm}$. in diameter, Radiolaria, Fish teeth.

Station 184, 26th November, 1899.

Lat. $20^{\circ} 15^{\prime} \mathrm{S}$. ; long. $172^{\circ} 0^{\prime} \mathrm{W}$. ; depth, 3141 fathoms.

RED CLAY : almost black in color, slightly coherent; may have been washed, as the percentage of minerals is quite 70 per cent of the whole sample; consists of angular mineral particles, mean dianeter $0.15 \mathrm{~mm}$., olivine, augite, volcanic glass, magnetite, palagonite, plagioclase, cosmic spherules.

Station 185, 27th November, 1899.

Lat. $21^{\circ} 18^{\prime} \mathrm{S}$. ; long. $173^{\circ} 31^{\prime} \mathrm{W}$.; depth, 4173 fathoms.

RED CLAY : light brown, slightly coherent; appears to have been washed; contains about 40 per cent of angular mineral particles, mean diameter $0.2 \mathrm{~mm}$., one piece of pumice $1 \mathrm{~cm}$. in diameter, brown volcanic glass abundant, augite, plagioclase, magnetite ; Radiolaria, and Sponge spicules.

Station 198, 2nd January, 1900.

Lat. $0^{\circ} 46^{\prime} \mathrm{N}$.; long. $173^{\circ} 9^{\prime} \mathrm{E}$. ; depth, 1365 fathoms.

GLOBIGERINA OOZE: cream colored, granular, incoherent; appears to have been washed; containing pelagic and bottom-living Foraminifera, 
THE DEPTH AND MARINE DEPOSITS OF THE PACIFIC OCEAN. 137

Echinoid spines, Ostracodes, coccoliths, rhabdoliths; Sponge spicules, Radiolaria, casts of Foraminifera ; particles of volcanic glass, felspar, magnetite.

Station 199, 2nd January, 1900.

Lat. $1^{\circ} 12^{\prime} \mathrm{N}$.; long. $173^{\circ} 5^{\prime} \mathrm{E}$; ; depth, 413 fathoms.

GLOBIGERINA OOZE(?): brownish gray, granular, incoherent; apparently washed; containing pelagic and bottom-living Foraminifera, Ostracodes, otoliths, Tunicate spicules, coccoliths, rhabdoliths; Radiolaria, Sponge fragments and spicules, arenaceous Foraminifera, perfect casts of Foraminifera; volcanic glass, and felspar.

Station 202, 3rd January, 1900.

Lat. $1^{\circ} 17^{\prime}$ N. ; long. $173^{\circ} 9^{\prime}$ E. ; depth, 1569 fathoms.

GLOBIGERINA OOZE: brownish gray, granular, incoherent; appears to have been washed; contains pelagic and bottom-living Foraminifera, Echinoid spines, coccoliths, rhabdoliths; minute particles of felspar, volcanic glass, and decomposed ferro-magnesian mineral.

Station 203, 4th January, 1900.

Lat. $1^{\circ} 40.5^{\prime} \mathrm{N}$; ; long. $172^{\circ} 59^{\prime} \mathrm{E}$.; depth, 170 fathoms.

Very little material, granular; appears to have been washed; consists of pelagic and bottom-living Foraminifera, Pteropods, Heteropods, Echinoid spines, otoliths, Ostracodes; minute particles of volcanic glass, and felspar.

Station 205, 4th January, 1900.

Lat. $2^{\circ} 4^{\prime} \mathrm{N}$. ; long. $173^{\circ} 16^{\prime} \mathrm{E}$. ; depth, 431 fathoms.

CORAL SAND: very little material, granular; appears to have been washed; contains Coral fragments, Mollusc-shell fragments, Echinoid spines, Alcyonarian spicules, pelagic and bottom-living Foraminifera, Heteropods, small Gasteropods, otoliths; Sponge spicules.

Station 207, 5th January, 1900.

Lat. $2^{\circ} 49^{\prime} \mathrm{N}$. ; long. $173^{\circ} 1^{\prime} \mathrm{E}$; ; depth, 1461 fathoms.

GLOBIGERINA OOZE: brownish gray, granular, incoherent; apparently washed; containing pelagic and bottom-living Foraminifera, Echinoid spines, coccoliths, rhabdoliths ; Radiolaria, Sponge spicules, Diatoms; minute particles of felspar, volcanic glass, and magnetite. 
Station 212, 9th January, 1900.

Lat. $5^{\circ} 44^{\prime}$ N. ; long. $169^{\circ} 45^{\prime}$ E. ; depth, 1937 fathoms.

GLOBIGERINA OOZE: brownish gray, granular, incoherent; apparently washed, containing pelagic and bottom-living Foraminifera, Echinoid spines, otoliths, Ostracodes, coccoliths, and rhabdoliths; Sponge spicules, Radiolaria ; minute mineral particles, angular, mean diameter $0.07 \mathrm{~mm}$., felspar, volcanic glass.

Station 214, 15th January, 1900.

Lat. $7^{\circ} 0^{\prime} \mathrm{N}$.; long. $169^{\circ} 1^{\prime}$ E. ; depth, 2137 fathoms.

GLOBIGERINA OOZE : very little material, granular, incoherent; appears to have been washed; contains pelagic and bottom-living Foraminifera, Echinoid spines, otoliths, Ostracodes, coccoliths, rhabdoliths; Radiolaria, Sponge spicules; felspar, volcanic glass.

Station 215, 15th January, 1900.

Lat. $7^{\circ} 8^{\prime} \mathrm{N}$.; long. $168^{\circ} 56^{\prime} \mathrm{E}$; ; depth, 1283 fathoms.

GLOBIGERINA OOZE: cream colored, granular, incoherent; appears to have been washed; contains pelagic and bottom-living Foraminifera, Echinoid spines, otoliths, Ostracodes, Fish scales, coccoliths, rhabdoliths; Radiolaria, Diatoms, Sponge spicules; felspar, volcanic glass.

Station 216, 15th January, 1900.

Lat. $7^{\circ} 29^{\prime} \mathrm{N}$. ; long. $168^{\circ} 32^{\prime} \mathrm{E}$. ; depth, 1068 fathoms.

GLOBIGERINA OOZE (?): gray in color, granular, incoherent; apparently washed; containing pelagic and bottom-living Foraminifera, Coral fragments, Mollusc-shell fragments, small Gasteropods, Polyzoa, Pteropods, otoliths, Ostracodes; Sponge spicules; mineral particles consisting of volcanic glass and felspar.

Station 217, 15th January, 1900.

Lat. $7^{\circ} 37^{\prime} \mathrm{N}$. ; long. $168^{\circ} 27^{\prime} \mathrm{E}$. ; depth, 906 fathoms.

GLOBIGERINA OOZE (?): brownish gray, granular, incoherent; appears to have been washed; contains pelagic and bottom-living Foraminifera, Pteropods, otoliths, Echinoid spines, Tunicate spicules, coccoliths and rhabdolitbs; Sponge spicules; particles of felspar and volcanic glass. 
Station 218, 15th January, 1900.

Lat. $7^{\circ} 45^{\prime}$ N. ; long. $168^{\circ} 21^{\prime}$ E. ; depth, 631 fathoms.

CORAL SAND (?) : gritty, coarsely granular, incoherent, gray in color; consisting of Coral fragments, pelagic and bottom-living Foraminifera, otoliths, Echinoid spines; small grains of manganese.

Station 221, 18th January, 1900.

Lat. $11^{\circ} 9^{\prime} \mathrm{N}$. ; long. $166^{\circ} 46^{\prime} \mathrm{E}$; ; depth, 400 fathoms.

CORAL SAND (?) : granular, incoherent, gray in color ; consisting of Coral and Mollusc-shell fragments, pelagic and bottom-living Foraminifera, Echinoid spines, Polyzoa, otoliths, small Gasteropods, Pteropod fragments, Heteropods, Tunicate spicules; Sponge spicules; minute particles of volcanic glass.

Station 222, 18th January, 1900.

Lat. $11^{\circ} 7.5^{\prime} \mathrm{N}$. ; long. $166^{\circ} 46^{\prime} \mathrm{E}$; ; depth, 827 fathoms.

CORAL SAND (?): very little material; incoherent, granular, gray in color; consisting of Coral and Mollusc-shell fragments, pelagic and bottomliving Foraminifera, Echinoid spines, otoliths, Ostracodes, small Gasteropods, Pteropods, Heteropods, Tunicate spicules; minute particles of volcanic glass, felspar, and magnetite.

Station 227, 21st January, 1900.

Lat. $9^{\circ} 48^{\prime} \mathrm{N}$. ; long. $169^{\circ} 14^{\prime}$ E. ; depth, 468 fathoms.

CORAL SAND (?): granular, incoherent, gray in color; appears to have been washed; containing Coral and Mollusc-shell fragments, Echinoid spines, Pteropods, Heteropods, small Lamellibranchs and Gasteropods, otoliths, Ostracodes, pelagic and bottom-living Foraminifera, Tunicate spicules; Radiolaria, Sponge spicules; Diatoms; minute mineral particles, angular, mean diameter $0.07 \mathrm{~mm}$., volcanic glass, felspar, and magnetite.

Station 228, 21st January, 1900.

Lat. $9^{\circ} 47^{\prime} \mathrm{N}$.; long. $169^{\circ} 14^{\prime} \mathrm{E}$. ; depth, 934 fathoms.

CORAL SAND(?): grayish white, incoherent; apparently washed; consisting of Coral and Mollusc-shell fragments, Echinoid spines, small Lamellibranchs and Gasteropods, otoliths, Ostracodes, pelagic and bottom-living Foraminifera, Tunicate spicules; Radiolaria, Sponge spicules; minute particles of volcanic glass, felspar, and magnetite. 
Station 229, 21st January, 1900.

Lat. $9^{\circ} 40^{\prime} \mathrm{N}$. ; long. $169^{\circ} 32^{\prime} \mathrm{E}$; ; depth, 1583 fathoms.

GLOBIGERINA OOZE : cream colored, granular, incoherent; apparently washed; containing pelagic and bottom-living Foraminifera, Echinoid spines, otoliths, Ostracodes, coccoliths and rhabdoliths; Radiolaria, Sponge spicules; particles of felspar, volcanic glass and magnetite.

Station 230, 23rd January, 1900.

Lat. $9^{\circ} 19^{\prime} \mathrm{N}$. ; long. $170^{\circ} 10^{\prime} \mathrm{E}$; d depth, 482 fathoms.

CORAL SAND (?): very little material, incoherent; apparently washed; containing Coral fragments, pelagic and bottom-living Foraminifera, Echinoid spines, Alcyonarian spicules, Polyzoa, fragments of Molluse shells, Tunicate spicules, coccoliths; Sponge spicules.

Station 231, 23rd January, 1900.

Lat. $9^{\circ} 17^{\prime} \mathrm{N}$.; long. $170^{\circ} 11^{\prime} \mathrm{E}$; ; depth, 1187 fathoms.

CORAL SAND or MUD (?): little material, incoherent; apparently washed ; containing Coral fragments, pelagic and hottom-living Foraminifera, Pteropod fragments, Mollusc fragments (including Dentulium, Cadulus, Cccum), Echinoid spines, Alcyonarian spicules, Polyzoa, Tunicate spicules, coccoliths and rhabdoliths; Sponge spicules.

Station 233, 24th January, 1900.

Lat. $7^{\circ} 54^{\prime} \mathrm{N}$.; long. $170^{\circ} 56^{\prime} \mathrm{E}$; ; depth, 1009 fathoms.

GLOBIGERINA OOZE (?): cream colored, granular, incoherent ; apparently washed; consisting of pelagic and bottom-living Foraminifera, Echinoid spines, otoliths, Ostracodes, Tunicate spicules, coccoliths, and rhabdoliths.

Station 234, 24th January, 1900.

Lat. $7^{\circ} 21^{\prime} \mathrm{N}$.; long. $171^{\circ} 35^{\prime} \mathrm{E}$; ; depth, 1326 fathoms.

GLOBIGERINA OOZE : little material, dirty white or cream colored, incoherent, fine-grained; apparently washed; consisting of pelagic and bottomliving Foraminifera, coccoliths, and rhabdoliths.

Station 235, 28th January, 1900.

Lat. $6^{\circ} 57^{\prime}$ N. ; long. $171^{\circ} 34^{\prime}$ E. ; depth, 1253 fathoms.

GLOBIGERINA OOZE: cream colored, granular, incoherent; appears to have been washed; contains pelagic and bottom-living Foraminifera, Echinoid 
THE DEPTH AND MARINE DEPOSITS OF THE PACIFIC OCEAN. 141 spines, otoliths, Ostracodes, coccoliths, and rhabdoliths; Sponge spicules, Radiolaria; minute particles of felspar, volcanic glass, and magnetite.

Station 239, 9th February, 1900.

Three fourths of a mile south of Port Lottin, Kusaie, Caroline Islands; depth, 371 fathoms.

VOLCANIC SAND or MUD : brownish gray, granular, incoherent; appears to have been washed; contains pelagic and bottom-living Foraminifera, Echinoid fragments and spines, Polyzoa, Pteropods, Heteropods, small Lamellibranchs and Gasteropods, Coral fragments, otoliths, Ostracodes, Tunicate spicules; large amount of mineral particles (almost 50 per cent of the material), angular, mean diameter $0.3 \mathrm{~mm}$., augite, a decomposed ferro-magnesian mineral (perhaps olivine), volcanic glass, apparently decomposed felspar, magnetite, and manganese grains.

Station 242, 14th February, 1900.

Lat. $6^{\circ} 55^{\prime} \mathrm{N}$.; long. $152^{\circ} 40^{\prime} \mathrm{E}$. ; depth, 526 fathoms.

CORAL SAND (?): gray, very little material ; consisting of one or two Coral fragments, measuring about $6 \mathrm{~mm}$. in diameter, Mollusc-shell fragments, small valve of an Ostrea, Echinoid spines, pelagic Foraminifera.

Station 247, 20th February, 1900.

Lat. $11^{\circ} 35^{\prime} \mathrm{N}$.; long. $147^{\circ} 15^{\prime}$ E. ; depth, 3213 fathoms.

RED CLAY : very little material, gritty, incoherent, gray brown in color; containing fragments of pumice, the largest being about $10 \mathrm{~mm}$. in length, much decomposed, some of the vesicles containing zeolitic crystals; angular mineral particles, consisting of volcanic glass, palagonite, pumice, felspar, augite, inagnetite, and manganese; Sponge spicules, one broken pelagic Foraminifer (Sphceroidina dehiscens) observed.

Station 248, 20th February, 1900.

Lat. $12^{\circ} 51^{\prime} \mathrm{N}$.; long. $145^{\circ} 46^{\prime} \mathrm{E}$. ; depth, 4813 fathoms.

RADIOLARIAN OOZE: this is the deepest sounding obtained by the "Albatross," and it would have been extremely interesting to have had a large sample of the deposit at our disposal, but unfortunately very little material was brought up, and it apparently does not represent the deposit in situ, being composed almost exclusively of the frustules of one of the largest known Diatoms (Ethmodiscus or Coscinodiscus), so that one would 


\section{THE DEPTH AND MARINE DEPOSITS OF THE PACIFIC OCEAN.}

feel inclined to call it a Diatom Ooze. There are also many Radiolaria, and small mineral particles, consisting of volcanic glass, felspar, and magnetite. It is probable that the Radiolarian Ooze, found in the deepest sounding taken by the "Challenger" further to the southwest, may extend to this position, but if so, most of the Radiolaria must have been washed out of the tube in process of collection, while the large cylindrical tenuous frustules of Ethmodiscus have remained behind.

Station 249, 21st February, 1900.

Lat. $13^{\circ} 8^{\prime}$ N. ; long. $145^{\circ} 25^{\prime}$ E. ; depth, 2337 fathoms.

RADIOLARIAN OOZE(?): very little material; apparently washed; including one or two pelagic and bottom-living Foraminifera, numerous Radiolaria, Sponge spicules, a few Diatoms, and many volcanic mineral particles, pumice, volcanic glass, palagonite, felspar, and magnetite.

Lagoon of Niau.

CORAL SAND (?): pale salmon pink in color, finely granular, incoherent; consisting of Coral fragments, small Lamellibranchs, bottom-living Foraminifera, and Tunicate spicules.

Anchorage, Vavau, Fiji Islands; depth, 18 fathoms.

CORAL SAND: grayish yellow, plastic, coherent; contains large Coral fragments, one measuring 1 by $\frac{3}{4}$ by $\frac{1}{8}$ inches, covered with Serpula, Molluscshell fragments, Ostrea 12 by $9 \mathrm{~mm}$., Cerithium $15 \mathrm{~mm}$. long, pelagic and bottom-living Foraminifera, Echinoid spines, otoliths, Ostracodes, portion of Crustacean's claw.

1st January, 1900 ; Sea Beach, South shore of Apamama Island, Gilbert Islands.

CORAL SAND : white, granular, incoherent; made up almost entirely of small angular and rounded pieces of Corals and Mollusc-shell fragments, mean diameter about $0.5 \mathrm{~mm}$., Echirroid spines, Tunicate spicules, Alcyonarian spicules; small fragments of pumice, the largest being 11 by 6 by $4 \mathrm{~mm}$.

26th September, 1899. Makatea (Aurora) Island, Paumotu Islands.

Fossils from the third terrace, about 200 feet above high water :-

(1) Fragment of Corals, 20 by 15 by $3 \mathrm{~mm}$., converted into calcite ; has almost entirely lost its original structure. 
THE DEPTH AND MARINE DEPOSITS OF THE PACIFIC OCEAN. 143

(2) Fragments of Corals, the largest 20 by 15 by $10 \mathrm{~mm}$, converted into calcite, and still retaining their original structure.

(3) Piece of white calcite, $1 \frac{1}{4}$ by 1 by $\frac{3}{4}$ inches, probably Coral, but it has lost all original structure; contains on one side a small Gasteropod shell, half an inch in length.

(4) Shell (Cypraea sp.) almost entirely transformed into dolomite, 15 by 11 by $7 \mathrm{~mm}$.

\section{Unlabelled Sample.}

One bottle, on which there was no label or number, contained black, finegrained material, coherent; consisting of about 50 per cent of mineral particles, angular, mean diameter $0.2 \mathrm{~mm}$., plagioclase, volcanic glass, hornblende, quartz, augite, magnetite, biotite; Sponge spicules; about 20 per cent calcium carbonate, consisting of pelagic and bottom-living Foraminifera in fragments, Mollusc-shell fragments, Echinoid spines, otoliths, and Ostracodes.

\section{Manganese Nodules.}

We give here descriptions of the manganese nodules obtained at the various stations of this 1899-1900 cruise of the "Albatross":-

Station 2, 27th August, 1899.

Lat. $28^{\circ} 23^{\prime} \mathrm{N}$.; long. $126^{\circ} 57^{\prime} \mathrm{W}$.; depth, 2368 fathoms.

Besides the rock fragments obtained at this station, described by Dr. Teall, the following were dredged:-

A large box and a large bag full of lumps of a whitish ashy material (described in detail in the Appendix), and three large bags full of manganese nodules, numbering many thousands of specimens (see Pl. 3, figs. 7 and 8), two of which are figured in Dr. Alexander Agassiz's preliminary report. ${ }^{1}$ The ashy material occurs as blocks of irregular shape, probably broken off some larger masses, some of which ( $\mathrm{Pl} .3$, fig. 7) represent a term of transition between cakes of ash and manganese nodules, as shown below.

The nodules collected at this station in immense numbers vary in diameter from 1 to $15 \mathrm{~cm}$, and show an extraordinary variety of shape; they are never rounded and symmetrical, but are angular with large protuberances. The larger ones have cylindrical holes running through the mass just as in the case of the ash lumps. All the nodules take on a shining lustre when rubbed with the finger-nail. The surface has not

${ }_{1}$ Mem. Mus. Comp. Zoöl., vol. XXVI., Plate, Manganese Nodules, figs. 5 and 6. 


\section{THE DEPTH AND MARINE DEPOSITS OF THE PACIFIC OCEAN.}

the shagreen appearance met with elsewhere, but in some cases there are minute mammillæ between the large protuberances. The specific gravity is higher in the small nodules than in the large ones, but is never very high.

A number of nodules were cut, but no nucleus was detected, nor any concentric arrangement of manganese layers; the manganese-iron oxides are distributed throughout a ground-mass of white material, which is certainly the same thing as the ashy substance mentioned above, but harder. The proportion of this substance to that of the oxides varies so much that in some cases it is difficult to say whether one is dealing with a nodule or with one of the lumps referred to above, but in the more perfect nodules that is, the small ones - the proportion of oxides predominates over that of the palagonite ground-mass.

To conclude: the very interesting point about these nodules is their mode of formation; they were not formed by the successive deposition of oxides round a nucleus, but are due to the impregnation of ash cakes by manganese-iron oxides without any increase in volume. Worm-burrows running through the hard nodules demonstrate this clearly, for the worms could not have burrowed through such a hard substance, so that their burrows existed before the deposition of the oxides.

It is also interesting to note that the white ground-mass of the more perfect nodules is harder and more compact than that of the nodules still poor in manganese-iron oxides.

Station 13, 5th September, 1899.

Lat. $9^{\circ} 57^{\prime} \mathrm{N}$. ; long. $137^{\circ} 47^{\prime} \mathrm{W}$.; depth, 2690 fathoms.

At this station a large quantity of nodules was dredged, one of which is figured in Dr. Alexander Agassiz's preliminary report. ${ }^{1}$ They somewhat resemble those of Station 4711 of the 1904 cruise. Here again they obey a law to which we have often had occasion to refer, all the nodules being formed under definite but unknown conditions, which brought on a definite type of structure.

They average 4 to 6 inches in diameter, and are all irregularly spherical or irregularly cubical, and never tend to form slabs. Their most conspicuous feature is the high degree of mammillated structure; the whole surface is covered with large protuberances, which may be as much as one inch in diameter. Sometimes these protuberances may be compounds, that is, formed 
of smaller ones grafted the one on the other. On the one side of the nodule the manmilla have a relatively smooth surface, on which rubbing will develop a shining lustre; on the other side the mammillæ are more dull, with a shagreen-like appearance.

A few remains of organisms can be seen attached to the nodules, mostly in the crevices separating the mammilla, and appear to be confined to the side with the dull surface, which is also the side on which the greater quantity of clay is still adhering.

All these nodules develop cracks within themselves, the cracks being orientated along the radii of the sphere, from centre to periphery. In this respect they resemble the septaria of sedimentary strata, but unlike them are not subsequently filled by deposition from solution. These cracks were most certainly developed when the nodules were on the sea-bottom, as is conclusively proved by the fact that their sides are covered with some of the clay in which the nodules were formed.

As regards mode of formation, in no case could a nucleus or centre of accretion be detected, but there is a typical concretionary structure in layers (reminding one of the structure of an onion). One layer of the hard, black manganese-iron oxide is enveloped by a layer of loose, practically incoherent, palagonitic substances containing only very little of the oxides, then comes another layer made up mostly of the oxides, then again a layer poor in oxides, and so on. It shows in a conclusive manner that the harder and blacker layers of the more compact nodules dredged elsewhere are also the layers richer in oxides. If infiltration and replacement had been allowed to go further in the present case, so as to bring on the formation of hard compact nodules, the two sets of layers would probably still have been recognizable.

To this alternation of layers is due the fact that the nodules not only break along the cracks already referred to, but break also in a tangential direction along the layers of incoherent palagonitic material. Under the microscope the latter is seen to contain, besides a yellowish palagonitic substance, a few crystalline particles, 0.02 to $0.05 \mathrm{~mm}$. in diameter, apparently augite, olivine, and felspar, together with a few microlites of a colorless min. eral, birefringent and extinguishing nearly straight. Magnetite is absent, and no cosmic spherules could be detected.

The successive layers of palagonitic material appear to have, as a rule, a constant composition, but in one case one of the layers is different from the others, being light yellow and formed of much finer material. Dendritic 


\section{THE DEPTH AND MARINE DEPOSITS OF THE PACIFIC OCEAN.}

ramifications appear to be constantly present, spreading from one oxide layer to another through the palagonitic layers.

Station 31, 19th September, 1899.

Lat. $12^{\circ} 20^{\prime} \mathrm{S}$. ; long. $144^{\circ} 15^{\prime} \mathrm{W}$.; depth, 2700 fathoms.

About one hundred small manganese nodules and small cakes and slabs of palagonite were obtained at this station. The nodules averaging 1 to $3 \mathrm{~cm}$. in diameter have a distinctive feature, - they are nearly always formed of smaller nodules cemented together; the shape of the composite nodules is therefore very irregular, the component individual parts being angular or bean-shaped. The surface is smooth and takes on a lustre when rubbed. As regards constitution, some of the nodules have an irregular nucleus of palagonite, round which are successive layers of manganese-iron oxides. Others are most likely the product of the impregnation of a cake of palagonite by the oxides. In fact, there are small fragments of palagonitic cakes showing incipient "manganization." Generally speaking, the nodules are not very solid, breaking easily along the radii; polished sections also show eracks along the radii.

The palagonitic nuclei contain more or less decomposed volcanic glass, some of which has still preserved its pellucidity, felspar, and apparently augite. The palagonite is represented either by angular cakes, 2 to $3 \mathrm{~cm}$. in diameter, light brown and rather soft, or by thin slabs (one was $25 \mathrm{~mm}$. by $5 \mathrm{~mm}$.), hard and bright yellow. Both kinds are thinly coated with manganese-iron oxide. The mineral particles contained in these palagonitic cakes and slabs are apparently the same as those extracted from the palagonitic nucleus of one of the nodules.

Station 173, 4th November, 1899.

Lat. $18^{\circ} 55^{\prime}$ S. ; long. $146^{\circ} 32^{\prime} \mathrm{W}$.; depth, 2440 fathoms.

These nodules, of which three are figured in Dr. Agassiz's preliminary report, ${ }^{1}$ constitute one of the most remarkable hauls of the cruise. At this station, where the deposit is Red Clay, immense numbers were dredged, varying in size from that of a small hazel-nut to potato-shaped nodules, three or four inches in diameter, and slabs over six inches in length (see Pl. 4, figs. 10, 12, 13, 14; Pl. 5, fig. 11). Although the shape varies, the surface characters are absolutely constant, and belong to a type which was met with only at this particular spot. The surface of all the nodules, large and small, is even, that is to say, not covered with protuberances, but it is not smoolh,

${ }^{1}$ Mem. Mus. Comp. Zoöl., vol. XXVI., Plate, Manganese Nodules, figs. 2-4. 
being covered with numberless closely set mammillæ, giving it the appearance of shagreen or coarse leather. On account of the presence of these mammillø - $1 \mathrm{~mm}$. in diameter, as a rule - the surface is dull, not shining. The color is brown, never black. The external layer, from 1 to $2 \mathrm{~mm}$. in thickness, peels off easily. In some cases the layer coming next to it shows shagreen structure; in other cases it does not, being smooth. This external layer is generally the only one that can be removed; the rest of the nodule is very compact, and so hard as to be scratched with a knife only with difficulty. When whole and with no fracture previously existing, the nodules cannot be broken in the hand, even when great strength is exerted; the specific gravity is very high.

All the nodules that were cut in order to study their structure were found to be formed round a nucleus, which is relatively large and invariably composed of a palagonitic tuff. The palagonitic substance forming the nucleus varies from a creamy white to a reddish color, the white portion being relatively soft and incoherent, whilst the red portion is so hard as to be cut with a knife only with difficulty. This tuff is most interesting, inasmuch as one can follow under the microscope its mode of formation: it is undoubtedly due to the decomposition of a volcanic glass, a few particles of which can still be recognized, as they have only partly lost their transparence, and can be seen to pass into opaque palagonite. A few scarce particles of partially decomposed olivine accompany the palagonite, together with rare particles of felspar. The presence of augite cannot be made absolutely certain, but it probably occurs together with the other minerals. These particles are only a few hundredths of a millimeter in diameter, but in one case the centre of a nucleus is occupied by a flake of volcanic glass about $2 \mathrm{~mm}$. in diameter.

The nucleus occupies a large portion of the nodule, its diameter varying from one-third to one-half of that of the whole nodule.

The manganese-iron oxides portion of the nodule does not pass gradually into the palagonitic nucleus, but envelops it without penetrating into it, so that a nucleus can be decorticated simply by fracturing the nodules and removing the manganese layer. The latter is very compact and homogeneous, so that indications of a concentric arrangement of the layers can hardly be made out, with the exception of the external, shagreen-like one. One of the nodules shows a peculiar structure; the nucleus is surrounded by a layer of oxides a centimetre in thickness, 


\section{THE DEPTH AND MARINE DEPOSITS OF THE PACIFIC OCEAN.}

then comes a thin layer of palagonitic tuff, identical with that of the nucleus, but only on one side of the nodule, so that in transverse section it forms a half circle midway between the nucleus and the surface. It looks as if a relatively small nodule had been covered on one side with palagonite, and as if the concretionary process had still gone on afterwards, enveloping it as it enveloped the nucleus. The heavy manganese-iron oxide layers contain a certain proportion of palagonite in the shape of small grains irregularly distributed, and not forming individualized layers. Pounded nodules showed the absence of magnetite and magnetic spherules.

The slabs differ from the nodules in shape only, and may be considered as flattened nodules, not as fragments detached from larger masses; the largest one measures 18 by 12 by $2 \frac{1}{2} \mathrm{~cm}$. Just as in the case of the nodules proper, a large flat nucleus is enveloped by manganese-iron oxides, having a finely mammillated structure all over, without any signs of fracture. All that can be said is that the shape of the slab follows the shape of the nucleus, but why the latter is flattened cannot be satisfactorily explained.

Station 174, 4th November, 1899.

Lat. $18^{\circ} 28^{\prime}$ S. ; long. $147^{\circ} 11^{\prime} \mathrm{W}$.; depth, 2087 fathoms.

Two small manganese nodules, each about $15 \mathrm{~mm}$. in diameter, form the only material obtained at this station. The one is oblong in contour, with nucleus of red palagonite, the other subspherical, harder than the first, with nucleus of whitish volcanic glass, the decomposition not being so far advanced. 


\section{THE DEPTHS OF THE PACIFIC OCEAN.}

The additions which have been made to our knowledge of the bathymetry of the Pacific Ocean in recent years, not only by Dr. Alexander Agassiz's cruises, but also by other American ships and by cable ships, make it desirable to summarize what is known of the depth of this great ocean at the present time. The general result has been to increase the area between 2000 and 3000 fathoms, and to limit the area greater than 3000 fathoms, while the various contour-lines of depth have become more complicated and definite. It may be said that the bathymetry of the Pacific is now known in all its broad general outlines.

On Map I. accompanying this paper, the depth conditions in the Pacific are indicated on an equal surface projection hemisphere by varying shades of blue color - the darker the shade of blue the deeper the water - contour lines being drawn in at depths of 100, 500,1000, 2000,3000,4000, and 5000 fathoms. All soundings in depths exceeding 1000 fathoms are indicated on the map by the first two figures: thus 1468 is given as 14,5269 as 52 , the last two figures being omitted. A similar map for the large part of the Pacific traversed by the "Albatross" during the 1899-1900 cruise was published in Dr. Alexander Agassiz's preliminary report ${ }^{1}$ in January, 1902, and a comparison of that map with the present one shows that in the interval of seven years few deep-sea soundings have been added to the southeastern regions of the Pacific, apart from those taken by the "Albatross" during the 1904-1905 cruise. Considerable differences may be noticed in the conformation of the deeper parts of the ocean, especially where the depth exceeds 3000 fathoms. This is to some extent due to the fact that in drawing in the deep contours the plan has been followed of extending the areas where there was no evidence to the contrary, and thus in many cases uniting together two or more areas previously isolated.

The southwestern portion of the Pacific lying to the east of Australia and Tasmania has been dealt with in great detail in a paper ${ }^{2}$ prepared by

1 Mem. Mus. Comp. Zoöl., vol. XXVI., no. 1, Map IB.

2 On the depth, temperature of the ocean waters, and marine deposits, of the Southwest Pacific Ocean. Queensland Geogr. Jour., N. S., vol. XXI., pp. 71-134, 1906. 
Sir John Murray for the anniversary celebration of the Royal Geographical Society of Australia, to which the reader is referred.

The entire Pacific Ocean, excluding the fringe of partially enclosed seas on its northern and western borders, that is to say, as bounded by the Aleutian Islands on the north, by the Antaretic continent on the south, by the Americas on the east, and by Kamschatka, the Kurile Islands, New Guinea, Australia, and Tasmania on the west, is estimated to cover an area exceeding sixty-two millions of square miles. Planimeter measurements give the following approximate areas between the consecutive contour lines of depth drawn in at intervals of 1000 fathoms, and the percentages to the total area :-

\begin{tabular}{|c|c|c|c|c|}
\hline Less than 1000 & thoms & & $\begin{array}{r}\text { Square Miles, } \\
5,610,000\end{array}$ & $\begin{array}{c}\text { Per Cent. } \\
9.0\end{array}$ \\
\hline 1000 to 2000 & " & 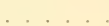 & $10,480,000$ & 16.8 \\
\hline 2000 to 3000 & $"$ & & $41,750,000$ & 67.0 \\
\hline 3000 to 4000 & “ & & $4,230,000$ & 6.8 \\
\hline More than 4000 & “ & . . . & 220,000 & 0.4 \\
\hline & & & $62,290,000$ & 100.0 \\
\hline
\end{tabular}

From this table it seems that by far the largest area (about two-thirds of the entire ocean) is that between 2000 and 3000 fathoms in depth. An inspection of the map shows this very well, for it is seen that the dominant shade is the fifth one, indicating depths of 2000 to 3000 fathoms, which is broken only by several irregular deeper and shallower areas.

Depths of less than 1000 fathoms (1829 metres) are found round the shores of the continents and islands and also in a few cases in the more central parts of the ocean where submarine elevations have been discovered.

Depths between 1000 and 2000 fathoms (1829-3658 metres) also occur round the coasts, but in some localities cover a much larger area than the shallower zone, as, for instance, off the coast of Central America, where there is a large area, which has been called the Galapagos Plateau; and, again, off the coast of South America, between $32^{\circ}$ and $50^{\circ} \mathrm{S}$., where there is a smaller area, which has been called the Juan Fernandez Plateau. In the South Pacific there is a broad tract extending from $38^{\circ}$ to $74^{\circ} \mathrm{S}$. and from $145^{\circ} \mathrm{E}$. to $105^{\circ} \mathrm{W}$., sending a branch northward into the Coral Sea; to the north of this is a large area, stretching from $8^{\circ}$ to $28^{\circ} \mathrm{S}$., and from $102^{\circ}$ to $142^{\circ} \mathrm{W}$., which has been called the Albatross Plateau. In the North Pacific there is a small area off the coast of Mexico, founded on two soundings taken during the "Albatross" 1904-1905 cruise, and a second small area between $175^{\circ}$ and $179^{\circ} \mathrm{E}$. and $21^{\circ}$ and $23^{\circ} \mathrm{N}$., as well as a few other small scattered areas. 
As already stated, the area between 2000 and 3000 fathoms (3658-5487 metres) in depth covers by far the greater part of the floor of the Pacific, and it is worthy of note that it forms an almost continuous area, for only in the southwest Pacific are there two separated areas: a comparatively small one in the Coral Sea, and a larger one in the sea between Australia and New Zealand, between $24^{\circ}$ and $52^{\circ} \mathrm{S}$. and $149^{\circ}$ and $165^{\circ} \mathrm{E}$., to which the name Thomson Basin has been given.

\begin{tabular}{|c|c|c|c|c|c|c|c|c|c|}
\hline \multirow{2}{*}{\multicolumn{6}{|c|}{ Name of Deep. }} & \multicolumn{2}{|c|}{ Position. } & \multirow{2}{*}{$\begin{array}{l}\text { Maximum } \\
\text { Depth } \\
\text { in Fathoms. }\end{array}$} & \multirow{2}{*}{$\begin{array}{l}\text { Approximate } \\
\text { Area in } \\
\text { Square Miles. }\end{array}$} \\
\hline & & & & & & Latitude. & Longitude. & & \\
\hline 1. & Murray & & & & & $27^{\circ} \mathrm{N}$. to $39^{\circ} \mathrm{N}$. & $149^{\circ} \mathrm{W}$. to $177^{\circ} \mathrm{W}$. & 3,500 & $1,033,000$ \\
\hline 2. & Tuscarora & . & 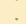 & 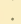 & & $23^{\circ} \mathrm{N}$. to $52^{\circ} \mathrm{N}$. & $142^{\circ} \mathrm{E}$. to $172^{\circ} \mathrm{E}$. & 4,600 & 908,000 \\
\hline 3. & Aldrich. & & & & & $15^{\circ} \mathrm{S}$. to $48^{\circ} \mathrm{S}$. & $169^{\circ} \mathrm{W}$. to $179^{\circ} \mathrm{W}$. & 5,155 & 613,000 \\
\hline 4. & Swire. & & & & & $5^{\circ} \mathrm{N}$, to $25^{\circ} \mathrm{N}$. & $122^{\circ} \mathrm{E}$. to $133^{\circ} \mathrm{E}$. & 4,700 & 550,000 \\
\hline 5. & Brooke & & & & & $12^{\circ} \mathrm{N}$. to $19^{\circ} \mathrm{N}$. & $152^{\circ} \mathrm{E}$. to $169^{\circ} \mathrm{E}$. & 3,400 & 282,000 \\
\hline 6. & Bailey. & & & & & $21^{\circ} \mathrm{N}$. to $28^{\circ} \mathrm{N}$. & $156^{\circ} \mathrm{E}$. to $180^{\circ} \mathrm{E}$. & 3,400 & 241,000 \\
\hline 7. & Belknap & & & & & $13^{\circ} \mathrm{N}$. to $17^{\circ} \mathrm{N}$. & $152^{\circ} \mathrm{W}$. to $163^{\circ} \mathrm{W}$. & 3,300 & 165,000 \\
\hline & Challenger & & & & & $11^{\circ} \mathrm{N}$. to $19^{\circ} \mathrm{N}$. & $142^{\circ} \mathrm{E}$. to $152^{\circ} \mathrm{E}$. & 5,269 & 129,000 \\
\hline 9. & Campbell & & & & & $1^{\circ} \mathrm{S}$. to $5^{\circ} \mathrm{N}$. & $166^{\circ} \mathrm{W}$. to $172^{\circ} \mathrm{W}$. & 3,400 & 125,000 \\
\hline 10. & Hilgard. & & & & & $4^{\circ} \mathrm{S}$. to $8 \circ \mathrm{S}$. & $165^{\circ} \mathrm{W}$. to $176^{\circ} \mathrm{W}$. & 3,300 & 116,000 \\
\hline 11. & Pourtalès & & & & & $11^{\circ} \mathrm{N}$. to $15^{\circ} \mathrm{N}$. & $140^{\circ} \mathrm{E}$. to $146^{\circ} \mathrm{E}$. & 3,600 & 67,000 \\
\hline 12. & Wyman & & & & & $21^{\circ} \mathrm{N}$, to $26^{\circ} \mathrm{N}$. & $147^{\circ} \mathrm{W}$. to $154^{\circ} \mathrm{W}$. & 3,300 & 55,000 \\
\hline 13. & Ammen & & & & & $19 \circ \mathrm{N}$. to $22^{\circ} \mathrm{N}$. & $172^{\circ} \mathrm{W}$. to $178^{\circ} \mathrm{W}$. & 3,100 & 31,000 \\
\hline 14. & Tanner & & & & & $32^{\circ} \mathrm{N}$, to $33^{\circ} \mathrm{N}$. & $136^{\circ} \mathrm{W}$. to $143^{\circ} \mathrm{W}$. & 3,200 & 21,000 \\
\hline 15. & Gray. & . & & & & $11^{\circ} \mathrm{N}$, to $13^{\circ} \mathrm{N}$. & $124^{\circ} \mathrm{W}$. to $127^{\circ} \mathrm{W}$. & 3,100 & 19,000 \\
\hline 16. & Maury & & & & & $52^{\circ} \mathrm{N}$. to $55^{\circ} \mathrm{N}$. & $157^{\circ} \mathrm{W}$. to $165^{\circ} \mathrm{W}$. & 3,600 & 17,000 \\
\hline 17. & Glover & & & & & $37^{\circ} \mathrm{N}$. to $39^{\circ} \mathrm{N}$. & $136^{\circ} \mathrm{W}$. to $137^{\circ} \mathrm{W}$. & 3,200 & 13,000 \\
\hline 18. & Bartholom & & & & & $18^{\circ} \mathrm{N}$. to $22 \circ \mathrm{S}$. & $72^{\circ} \mathrm{W}$. to $73^{\circ} \mathrm{W}$ & 3,500 & 13,000 \\
\hline 19. & Supan. & & & & & $50^{\circ} \mathrm{N}$. to $51^{\circ} \mathrm{N}$ & $173^{\circ} \mathrm{W}$. to $176^{\circ} \mathrm{W}$. & 4,000 & 12,000 \\
\hline 20. & Richards. & & & & & $24^{\circ} \mathrm{S}$. to $26^{\circ} \mathrm{S}$. & $71 \circ \mathrm{WV}$. to $72 \circ \mathrm{W}$ & 4,100 & 12,000 \\
\hline 21. & Milne-Edw & war & rds & & & $11^{\circ} \mathrm{s}$. to $13^{\circ} \mathrm{s}$. & $79^{\circ} \mathrm{W}$. to $80^{\circ} \mathrm{W}$ & 3,300 & 8,000 \\
\hline 22 . & Renard. & . & & & & $19^{\circ} \mathrm{N}$. to $22^{\circ} \mathrm{N}$. & $155^{\circ} \mathrm{W}$. to $156^{\circ} \mathrm{W}$. & 3,100 & 6,000 \\
\hline 23. & Dana . & ${ }^{\circ}$ & & & & $7^{\circ} \mathrm{N}$. to $8^{\circ} \mathrm{N}$. & $134^{\circ} \mathrm{E}$. to $135^{\circ} \mathrm{E}$. & 4,400 & 6,000 \\
\hline 24. & Weber & & & & & $5^{\circ} \mathrm{S}$ & $131^{\circ} \mathrm{E}$ & 4,100 & 1,000 \\
\hline 25. & Krümmel & & & & & $7 \circ \mathrm{S}$ & $74^{\circ} \mathrm{W}$ & 3,700 & 1,000 \\
\hline 26. & Haeckel. & & & & & $33^{\circ} \mathrm{S}$ & $74^{\circ} \mathrm{W}$ & 3,000 & 1,000 \\
\hline 27. & Bache. & ${ }^{\circ}$ & & & & $33^{\circ} \mathrm{N}$. & $130^{\circ} \mathrm{W}$. & 3,200 & 1,000 \\
\hline 28 . & Moser. & ${ }^{\circ}$ & & & & $17 \circ \mathrm{N}$. & $137^{\circ} \mathrm{W}$ & 3,000 & 1,000 \\
\hline 29. & Garrett & $\cdot$ & & & & $4 \circ \mathrm{S}$ & $172 \circ \mathrm{W}$ & 3,000 & 1,000 \\
\hline 30. & Thomson & & & & & $32 \circ \mathrm{S}$ & $153^{\circ} \mathrm{E}$ & 3,000 & 1,000 \\
\hline 31. & Oldham. & & & & & $7 \circ \mathrm{S}$. & $131^{\circ} \mathrm{E}$. & 3,500 & 1,000 \\
\hline
\end{tabular}

In recent oceanographical literature the term "Deep" has been applied to those parts of the ocean where the depth exceeds 3000 fathoms (5487 metres). There are altogether 31 Deeps shown on the accompanying map of the Pacific, and these are for the most part confined to the western half of the ocean. They have been named after ships which have had some connection with deep-sea exploration, or naval officers, geographers, or naturalists interested in oceanography. In the preceding table are given the names, posi- 
tions, maximum depths, and approximate areas of the deeps in the Pacific, arranged according to their superficial area.

As will be seen from the foregoing table in only eight of these Deeps have depths exceeding 4000 fathoms (7316 metres) been taken, and in only two have depths exceeding 5000 fathoms (9144 metres) been recorded. The deepest sounding known at the present time is one of 5269 fathoms in the Challenger Deep, obtained by the U. S. S. "Nero" near Guam Island, one of the Ladrone group in the North Pacific, in November, 1899. Previously, the deepest sounding known was one of 5155 fathoms in the Aldrich Deep in the South Pacific. These are the only places on the surface of the globe where depths of 5000 fathoms have been recorded. 


\section{DISTRIBUTION OF MARINE DEPOSITS IN THE PACIFIC OCEAN.}

Dr. Agassiz's explorations have greatly increased the area with depths between 2000 and 3000 fathoms in the southeastern Pacific, which likewise increases the area covered by deposits of Globigerina Ooze, for this type of deposit is most widely distributed in these depths.

On Map II. accompanying this paper the distribution of the different types of deposits is shown by different colors. No attempt is made to indicate the distribution of all the individual types of terrigenous deposits, Coral Muds and Coral Sands being shown by a yellow color, while the remaining types of terrigenous deposits (Volcanic Muds and Sands, Green Muds and Sands, Red Muds, and Blue Muds) are all included in the blue color on the map. A similar map was published in Dr. Agassiz's preliminary report ${ }^{1}$ in January, 1902, the principal modification being the large area of Globigerina Ooze now introduced in the southeast Pacific, as the result of the recent cruise of the "Albatross."

Planimeter measurements give the following approximate areas covered by the various types of deposits within the Pacific Ocean, as already defined, and the percentages to the total area:-

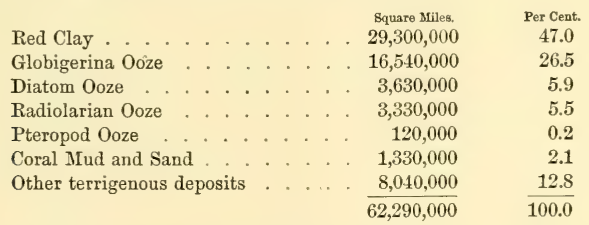

This table shows that by far the most important deposit in the Pacific is the Red Clay, which is estimated to cover an area nearly twice as large as that covered by Globigerina Ooze, and about eight times greater than that covered by either Diatom Ooze or Radiolarian Ooze. A glance at the map corroborates this statement, for it is seen that Red Clay occupies 
nearly all the northern Pacific, and Red Clay and Globigerina Ooze together the greater part of the southern Pacific.

The distribution of the different types of deposits in the Pacific Ocean may be briefly summarized as follows :-

I. Red Clay. - There are nine areas covered by this type, but four are small, viz., one based on a single sounding to the southwest of Galapagos, a second to the west of the New Hebrides, a third in the centre of the Coral Sea, and a fourth in the sea between New Zealand, New Caledonia, and the Fiji Islands. Of the larger areas, one is laid down in the deep water between New Zealand and Tasmania and Australia, extending from $25^{\circ}$ to $55^{\circ}$ south latitude, and having a breadth in its southern portion of about $15^{\circ}$ of longitude. Two other areas touch the terrigenous band bordering the west coast of South America, one extending from $5^{\circ}$ to $35^{\circ}$ south latitude, the other extending from $45^{\circ}$ to nearly $60^{\circ}$ south latitude. The remaining two areas of Red Clay are by far the largest, and might be termed the North Pacific area and the South Pacific area respectively, though in the one case the Red Clay extends about $18^{\circ}$ south of the equator, and in the other about $8^{\circ}$ north of the equator. The South Pacific area covers about seven millions of square miles in the centre of the ocean, and is surrounded by Globigerina Ooze and Radiolarian Ooze. The North Pacific area covers about eighteen millions of square miles, and is surrounded by a band of Diatom Ooze in the extreme north, by borders of terrigenous deposits along the coasts of North America and Asia, and by bands of Radiolarian Ooze and Globigerina Ooze on the south.

II. Globigerina Ooze. - This type covers a large, but very irregular, area in the South Pacific, consisting of two portions joined by a narrow band along the south; the eastern portion covers an area of about eight millions of square miles, stretching from $8^{\circ}$ north to $56^{\circ}$ south latitude, and touching the band of terrigenous deposits bordering the west coast of South America both in its northern and southern parts; the western portion is much smaller, and is broken up by areas of Red Clay, of Pteropod Ooze, and of terrigenous deposits, stretching from $5^{\circ}$ north to $59^{\circ}$ south latitude, and from the coasts of Australia and Tasmania to the Chatham, Kermadec, and Friendly groups of islands. Another area of Globigerina Ooze covers about a million square miles in the central part of the Pacific, stretching from $133^{\circ}$ to $165^{\circ}$ west longitude, and from $12^{\circ}$ 
THE DEPTH AND MARINE DEPOSITS OF THE PACIFIC OCEAN. 155

north to $2^{\circ}$ south latitude, the southern boundary coinciding with the parallel of $2^{\circ}$ south. A third considerable area of Globigerina Ooze surrounds the Caroline archipelago, and a fourth surrounds the Marshall and Gilbert archipelagos, while several small isolated areas surround the scattered groups of islands, and cover the summits and flanks of some submarine elevations. It will be observed that generally the Globigerina Ooze is found in depths between 1000 and 2300 fathoms, while the Red Clay is found in depths exceeding 2300 fathoms. There are, however, important exceptions to this statement.

III. Diatom Ooze. - This type occurs in the form of two broad bands, the larger in the far south and the smaller in the far north. The southern one forms part of the circumpolar band surrounding the Antarctic continent, outside the band of Blue Mud, and covers an area of about two and a half millions of square miles, while the northern one stretches across the northern boundary of the Pacific, from Japan on the west to Vancouver on the east, and covers over a million square miles. One of the most interesting results of the recent expedition of the "Albatross" is the discovery of this type of deep-sea deposit, so characteristic of high latitudes, within the tropics, viz., in latitude $12^{\circ}$ south, off the west coast of South America, where, however, it has apparently a very restricted area of distribution.

IV. Radiolarian Ooze. - This type covers two large and two or three small areas in the tropical part of the Pacific. The most important one is the comparatively narrow band in latitude $10^{\circ}$ north, stretching from $165^{\circ}$ to $80^{\circ}$ west longitude, and covering an area of nearly two million square miles. A second area, nearly a million square miles in extent, stretches from latitude $8^{\circ}$ north to $12^{\circ}$ south, and from longitude $180^{\circ}$ to $164^{\circ}$ west. Of the other smaller areas, one occupies the Challenger Deep in the North Pacific, extending from $143^{\circ}$ to $147^{\circ}$ east longitude and from $12^{\circ}$ to $15^{\circ}$ north latitude, and two lie in the South Pacific, one in latitude $3^{\circ}$ to $8^{\circ}$ south and longitude $151^{\circ}$ to $153^{\circ}$ west, the other in latitude $10^{\circ}$ south and longitude $156^{\circ}$ west.

V. Pteropod Ooze. - It is rather curious to note the absence of this type in the northern and eastern Pacific, the most northerly and easterly position hitherto known being latitude $9^{\circ}$ south and longitude $139^{\circ}$ west in the Marquesas group. Several small areas of Pteropod Ooze are dotted over the western portion of the Globigerina Ooze area of the South Pacific, especially 
in the neighborhood of the Great Barrier Reef of Australia and the Fiji group of islands, and a few among the islands of the Paumotu and Marquesas groups, the aggregate area being relatively very small. This deposit may be said to be limited to tropical and sub-tropical areas where the depth is less than 1500 fathoms at a considerable distance from land.

VI. Coral Mud and Sand. - These deposits are found encircling the many coral islands in the tropical and subtropical regions of the Pacific, and off the Great Barrier Reef of Australia, the aggregate area covered by these types being estimated to exceed a million square miles.

VII. Other Terrigenous Deposits.-The terrigenous deposits other than Coral Mud and Sand cover an area of about eight millions of square miles, forming a border around the shores of the Pacific, and around the continental and volcanic islands, like Japan, the Philippines, New Guinea, the Solomons, the New Hebrides, Tasmania, New Zealand, etc. Blue Mud covers that part of the ocean between the Diatom Ooze of the far south and the Antarctic continent, forming part of the great circumpolar band bordering that continent. 


\section{PERCENTAGE OF CALCIUM CARBONATE IN THE DEPOSITS COVERING THE FLOOR OF THE PACIFIC OCEAN.}

Map III. accompanying this paper represents the first attempt to show the percentage of calcium carbonate in the deposits of the Pacific Ocean as a whole. A similar map for the southwestern portion of the Pacific was published in 1906 (Murray, op. cit., Map V.).

As regards the source of the calcium carbonate found in marine deposits it may be stated that by far the larger part has been derived from sea water by the action of organisms, being made up of fragments of Fish bones, Mollusc shells, Corals, spicules of Tunicates and Sponges, shells of Foraminifera, remains of calcareous Algæ, and, indeed, remains of all the calcareous structures secreted by marine organisms.

A very important division may be made of the calcareous remains into two classes, viz., those which have been secreted by organisms living habitually in the surface and subsurface waters of the ocean, such as pelagic Molluses, pelagic Foraminifera, and pelagic calcareous Algæ (plankton organisms), and those which have been secreted by organisms living on the bottom of the ocean (benthos organisms).

The remains of all the pelagic (plankton) organisms are especially abundant in the deposits far from land and in moderate depths. Near the land their presence is masked by detrital matters, while in great depths they disappear, being dissolved by the action of sea water either while falling to the bottom or soon after reaching the bottom. In depths of 1000 fathoms far from land they may make up fully 95 per cent of the deposit.

The remains of organisms which live at the bottom of the ocean (benthos), such as Corals, Molluses, Foraminifera, etc., are very poorly represented in deep water, but in shallow water they may make up nearly the whole of the deposit now in process of formation; this is especially the case round coral islands.

On the accompanying map the percentage of calcium carbonate in the deposits is shown by four shades of green color, the deeper the shade the higher the percentage. Planimeter measurements give the following 
approximate areas covered by the different shades of color, and the percentages to the total area :-

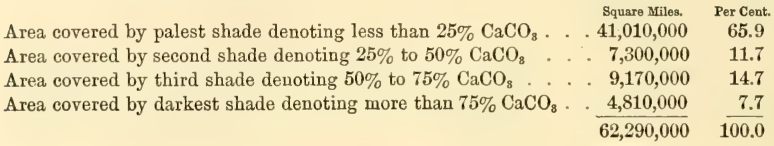

This table indicates that by far the largest area is covered by the shade denoting less than 25 per cent of calcium carbonate, which is about six times greater than the area covered by the next shade ( 25 to 50 per cent), five times greater than the area covered by the third shade denoting 50 to 75 per cent, and ten times greater than the area covered by the darkest shade, indicating over 75 per cent of calcium carbonate. This lightest shade of green covers nearly the whole of the North Pacific as well as a large part of the South Pacific. In the North Pacific there are only three large areas covered by the darker shades of green, viz., one surrounding the Caroline Islands, a second surrounding the Marshall and Gilbert archipelagos, and a third stretching from $137^{\circ}$ to $163^{\circ}$ west longitude and from $9^{\circ}$ north to $3^{\circ}$ south latitude, with many small areas surrounding coral islands and on submarine elevations. In the South Pacific, on the other hand, there is a large dark-colored area consisting of two portions, one in the east and one in the west, joined by a narrow band along the south, and stretching from $58^{\circ}$ south to $7^{\circ}$ north latitude. These portions are separated by a central area of lightest green, and while the western one abuts on the Great Barrier Reef of Australia, the eastern one is separated from the coast of South America by an area covered by the lightest color.

The second shade of green, denoting 25 to 50 per cent of calcium carbonate, covers a smaller area than the third shade, indicating 50 to 75 per cent of calcium carbonate, forming generally an irregular border to the dark areas where the percentage exceeds 50 .

On comparing this map with the depth map it will be observed that the higher percentages of carbonate of calcium correspond generally with the moderate depths of the ocean and to the shore regions where coral reefs prevail, while the lower percentages correspond with the very deep water and to the shallow water around the continents and islands not of coral formation. 
THE DEPTH AND MARINE DEPOSITS OF THE PACIFIC OCEAN. 159

On comparing this map with the deposit map it will be observed that away from the coast the deep shades correspond with the Globigerina and Pteropod Oozes. Thus the outlines of the principal Globigerina Ooze areas are almost exactly reproduced in the darker shades of green. Again, the faint shades of green on the map correspond with the areas showing Red Clay and terrigenous deposits excluding coral deposits. 


\section{GENERAL REMARKS AND CONCLUSIONS.}

The character of a deep-sea deposit is determined not only by the depth and conditions of the overlying waters but also by the geographical environment of those waters, including volcanic phenomena which may take place on the floor of the ocean. It may here be proper to follow out the general changes in the nature of the deposits which may be expected on proceeding from the remotest land-locked branches of the ocean to its midmost areas.

The Black Sea, to take an extreme instance of enclosed seas, is far removed from the great oceans, and the deeper water is cut off by submarine barriers at the Bosphorus and the Straits of Gibraltar. Vertical circulation is much restricted by this and other physical conditions, and the deeper waters of the Black Sea become more or less saturated with sulphuretted hydrogen; no living organisms other than bacteria are met with in depths greater than 100 fathoms. Amorphous pulverulent carbonate of lime is precipitated from the sea water of the Black Sea, and makes up a consider able part of the deposits now in process of formation; this is the only place where this reaction is known to occur in the seas of the present day, with one doubtful exception in the Pacific (see Station 4531). In all partially enclosed seas - like the Mediterranean and the Red Sea-circulation is generally cut off by submarine barriers, and this produces temperature and other conditions which are less favorable to organisms than the conditions existing in the open ocean, where free communication with polar waters obtains, and where there is consequently a more abundant supply of oxygen. The deposits in those seas which interpenetrate the continental masses are terrigenous in origin, although there may be an approach to pelagic conditions towards the more central parts, as for instance in the Red Sea.

The continental shelf facing the great oceans is continually swept by waves, tides, and oceanic currents, down to an average depth of 100 fathoms. Just beyond this depth all the minute mineral and organic fragments torn from the continental shelf come to rest on the bottom, and form what Sir John Murray has called the mud-line. This constitutes the great feeding- 
THE DEPTH $\Lambda$ ND MARINE DEPOSITS OF THE PACIFIC OCE $\mathrm{N}$. 161

ground of the ocean. Large numbers of Holothurians and other marine creatures here eat the mud to obtain the organic matter associated with it; indeed, it is more than probable that all marine deposits are in this way passed through the intestines of organisms. Very many Crustaceans frequent this area to pick up the little particles of organic matter which are just settling on the bottom, and some of them-like Nyctiphanes-are provided with phrosphorescent organs to enable them to do this more effectively. All these mud-eating creatures are in turn the prey of carnivorous animals, both vertebrate and invertebrate.

The continental slope extends from the mud-line (100 fathoms) down to the mean sphere level, 1450 fathoms. $^{1}$ The continental slope, and similar areas around oceanic islands, present a greater variety of conditions than is found elsewhere on the ocean-bed beyond the continental shelf. At the upper limit the sun's rays may produce twilight, but elsewhere there must be total darkness, except where this is relieved by the phosphorescent light of organisms. The temperature conditions are likewise widely different at the upper and lower limits of the region. At some points the descent from the 100 -fathoms line is known to be almost perpendicular; at other points outcrops of stratified and volcanic rocks are indicated; generally, however, the slope is by no means pronounced, though much steeper than between the deeper contour-lines.

The deposits now being laid down over the continental slope vary greatly according to position: off large rivers they are chiefly made up of detritus from the land; at other places, especially where cold and warm currents alternately occupy the surface, pelagic conditions are more or less approached, and Green Sand and phosphatic deposits are being laid down; quartz and other continental minerals predominate. Generally it may be said that in enclosed seas, and along the continental shelf and slope, deposits are now forming which are chiefly made up of continental detritus, and are quite similar to those which have made up the stratified rocks of past ages. Indeed, it seems as if inland seas and the borders of continental masses had again and again been pushed up into dry land, and again and again been torn down and transported to the ocean by the same denuding and disintegrating agents, the final result being that quartz particles

1 If all the elevated portion of the earth's crust were cut away and filled into the hollows till the whole surface were uniform, then the whole earth would be covered by an ocean 1450 fathoms in depth - the mean sphere level. 
accumulate on the continental areas, rendering these rocks specifically lighter than the deposits on the oceanic areas.

In the abysmal regions, beyond the depth of the mean sphere level, covering about one-half of the earth's surface, the physical conditions are uniform and widespread; the temperature everywhere approaches zero centigrade; the darkness is relieved only by phosphorescent light; motion of all kinds must be extremely slow, and there is no evidence of transport or erosion, although where the abysmal area passes into the continental slope a creep of large masses of deposits is sometimes indicated. In these cold and silent depths, which are undoubtedly affected at times by volcanic outbursts, the deposits generally vary according to the surface conditions: where carbonate of lime secreting organisms abound at the surface Globigerina Ooze or Pteropod Ooze is found at the bottom; where silica-secreting organisms abound at the surface, Radiolarian Ooze or Diatom Ooze is found at the bottom. In very great depths, however, the carbonate of lime remains are removed by solution, and in some places the siliceous skeletons are also partly or wholly removed. In the deep water of the South Pacific Ocean, at points the furthest removed from continental land on the globe, the trawl brings up, in a single haul, over wide areas, hundreds of sharks' teeth and dozens of ear-bones of whales, belonging to extinct species, tons of manganese nodules, and mixed up in the Red Clay magnetic spherules of metallic iron and nickel and chondres, which are only found in meteorites. All the indications go to show that the rate of accumulation of the deposit is extremely slow, possibly not more than a foot since tertiary times. The reason why these teeth and bones and extra-terrestrial spherules are found here more abundantly than elsewhere is because few other materials reach these remote and deep areas to cover them up or mask them as in other deposits.

The above is the explanation which has hitherto been advanced to account for the phenomena presented by the deep-sea deposits situated far from continental land towards the central regions of the great ocean basins. Generally speaking it seems to be a sufficient explanation. The large number of deposits which have now been procured and examined from the central regions of the Pacific present, however, in some cases, difficulties; for instance, at Stations 4719 and 4544 , where the depths are respectively 2285 and 1955 fathoms, we have deposits of Red Clay without any calcium carbonate. Thus at these relatively shallow depths a pure Red Clay is found where we should 
under ordinary circumstances expect to find a Globigerina Ooze. Indeed, in the case of Station 4719, the adjacent stations, where the depth is quite similar, give Globigerina Oozes containing over 50 per cent of calcium carbonate. It seems, therefore, that in these exceptional cases some hypogene action has taken place, resulting in the removal of the whole of the calcium carbonate shells and remains from the deposit. That some such action had taken place at the bottom of the sea was indicated at a few stations during the "Challenger" expedition, but from the larger number of instances revealed by the examination of Dr. Agassiz's collections this explanation seems now clearly necessary. Again, at Station 4531, where the percentage of calcium carbonate is 72 , the calcareous shells have disappeared, and the deposit consists of a large quantity of comminuted particles of calcium carbonate together with coccoliths and Tunicate spicules. Probably this calcium carbonate has all been derived from the shells of marine organisms, but these have disappeared through some hypogene action. Possibly there may also have been a chemical precipitation of calcium carbonate.

The mineral particles found in Red Clay and Globigerina Ooze are nearly always of volcanic origin, and we may once more draw attention to the great rôle that palagonite and allied minerals play in the southern Pacific Ocean. This distribution of decomposed basic volcanic elements coincides with the frequent occurrence of phillipsite, and explains the presence of this mineral in Globigerina Ooze as well as in Red Clay, its origin being thus independent of a question of great depth. The same may be said of manganese concretions and nodules; being generally found far from land, the origin of the manganese is not to be sought for in the products of continental erosion, but in those of the decomposition of the volcanic elements we have found to be so widely distributed.

It must be remembered that the Red Clay of the deeper parts of the ocean has no definite composition. It is made up of materials from very different sources, as we have just seen. In the South Pacific basic volcanic rocks, like sideromelan and palagonite, predominate; in the North Pacific the triturated fragments of pumice are most abundant. In some parts of the Atlantic the Red Clay receives additions which have a continental origin, as in the case of sand grains transported by the Harmattan Winds off the west coast of Africa.

Dr. W. A. Caspari, who has been assisting in chemical examination of the deposits in the "Challenger" Office, has prepared some notes upon his exami- 
164 THE DEPTH AND MARINE DEPOSITS OF THE PACIFIC OCEAN.

nation of a palagonitic tuff from Station 2 and of the peculiar Red Clay above referred to, from Station 4719, and these appear as an appendix to this paper.

Throughout the abysmal area, quartz grains, when present, are rare, compared with their abundance in the terrigenous deposits close to shore, and it is very doubtful if any stratified rock has yet been discovered which can be regarded as the equivalent of any deposit now forming in the deep water far from continental land. It is extremely difficult to picture to one's self how a continent, such as we understand the term, could ever have existed in the centre of any of the great ocean basins, which appear to be the most stable portions of the earth's crust, while the continental areas, especially the border regions, are the most unstable. 


\title{
APPENDIX. \\ NOTES ON THE EXAMINATION OF MATERIALS FROM STATION 2 (1899-1900 CRUISE) AND STATION 4719 (1904-1905 CRUISE).
}

By W. A. Caspari.

\author{
A. Palagonitic Tuff from Station 2, 2368 fathoms. \\ B. Red Clay from Station 4719,2285 fathoms.
}

\section{A. PALAGONITIC. TUFF from Station 2, 2368 fathoms.}

At the suggestion and under the direction of Sir John Murray, this substance, which is somewhat of a novelty in deep-sea deposits, was submitted to a special investigation.

The tuff was brought up in large blocks and slabs, some of them the size of a bucket.

It is of a ereamy-white color and rotten consistency, crumbling to a floury powder when rubbed. Interspersed in the mass are numerous minute grains of black manganese, a thin deposit of which also covers the irregularly mammillated upper surfaces. Most of the blocks have been much bored by worms, and the tunnels thus formed have silted up with Red Clay.

Viewed under the microscope, it appears as an apparently amorphous substance of very loose texture, with no features, apart from specks of manganese, to interrupt its homogeneity, except a few easts of Globigerina shells. The casts occur very rarely, but are remarkably well formed when they do occur; the internal and external casts are of the same material, and between them the shell itself has been dissolved out, leaving an empty space, across which run innumerable threads of the casting matter, corresponding to foramina which have been filled up. Under a high power, the crushed substance is seen to consist of transparent particles, mean diameter about $0.005 \mathrm{~mm}$., many of which are of parallelsided or prismatic habit, though indisputably crystallographic contours could not be detected. Micro-sections show an intricately felted, homogeneous network, at the boundaries of which can be perceived aggregations, which have broken loose from the mass, strongly resembling twinned prisms. On the whole, the substance seems to have a subcrystalline character.

Moistened with water, the substance loses coherence and turns to a pale yellowishbrown color. On drying, it resumes its whiteness; it does not bake hard, and can be crushed by the fingers even after exposure to dull red heat. It is therefore not of the nature of a clay.

By elutriation with water, followed by separation with bromoform, some particles of undecomposed minerals can be extracted. They are present to the extent of fairly exactly 1 per cent, have a mean diameter of $0.15 \mathrm{~mm}$., and consist for the greater part of oligoclase, which is mostly in very fresh condition; there are also green tabular splinters of voleanic glass, an unidentified mineral (olivine?), which has decomposed to a red amorphous body, and a little magnetite. 
A quantity of the substance was prepared for analysis by elutriating away from the heavier admixtures, washing several times with distilled water, collecting on a filter and drying. Treatment with dilute acid is not ouly unnecessary, since calcium carbonate is absent, but harmful, inasmuch as the substance is very sensitive to even dilute acids. It is a hydrated silicate, and has the typically zeolitic property of assuming whatever degree of hydration brings it into equilibrium with its environment. Hence constant results cannot be obtained by drying it either in air or in the oven. Roughly, there are about 18.5 per cent of moisture in the air-dried material, and about 7.6 per cent after drying at $110^{\circ} \mathrm{C}$. Heated to $300^{\circ} \mathrm{C}$. it is not completely dehydrated, and reabsorbs moisture on exposure. At red heat it turns buff-colored and ceases to be hygroscopic. Even then, however, it still retains 1 per cent or so of moisture, the last traces of which are only driven off by heating to incipient white heat, when the substance sinters to a light brown, opaque glass.

The analysis, reduced to terms of anhydrous material, runs as follows : -

\begin{tabular}{|l|c|c|}
\hline & $\begin{array}{c}\text { Palagonitic Tuff, } \\
\text { "Albatross" Btation 2. }\end{array}$ & $\begin{array}{c}\text { Phillipsite, } \\
\text { "Challenger" Station 275. } \\
\text { (Mean of three analyse日.) }\end{array}$ \\
\hline & 63.40 & 58.60 \\
$\mathrm{SiO}_{2}$ & 19.82 & 20.55 \\
$\mathrm{Al}_{2} \mathrm{O}_{8}$ & 3.72 & 7.03 \\
$\mathrm{Fe}_{2} \mathrm{O}_{3}$ & 0.52 & 0.41 \\
$\mathrm{MnO}_{2}$ & 0.98 & 2.52 \\
$\mathrm{CaO}$ & 3.65 & 1.39 \\
$\mathrm{MgO}_{\mathrm{O} O}$ & 5.14 & 5.92 \\
$\mathrm{~K}_{2} \mathrm{O}$ & 3.49 & 4.98 \\
$\mathrm{Na}_{2} \mathrm{O}$ & & \\
\hline & 100.72 & 101.40 \\
\hline
\end{tabular}

Since all deep-sea deposits formed in situ retain a certain ballast of undecomposed rocksilicates, these were separated by treating the material with boiling sulphuric acid, followed by dilute alkali, when a residue of 7.1 per cent of rock-silicates was found. This contained 69.3 per cent of $\mathrm{SiO}_{3}$ and 19.7 per cent of $\mathrm{Al}_{2} \mathrm{O}_{3}$, so that it cannot affect the bulk analysis seriously.

The analysis is chiefly remarkable for the high content of alkalies, such as is unknown in any secondary deep-sea silicate except palagonite, glauconite, and phillipsite. Altogether the substance approximates to phillipsite in composition, as is seen by comparison with the foregoing mean of three phillipsite analyses from Murray and Renard (Challenger Report on Deep-Sea Deposits, page 404).

Final proof of the zeolitic nature of the substance is afforded by its behavior towards dilute acids, to which it readily gives up alkalies and alumina. Even when it was attempted to elear the substance of manganese for analysis, by treatment with cold dilute acid and $\mathrm{So}_{2}$, the figures for the bases were found too low.

An extraction of a sample containing 18.36 per cent of total water was carried out by heating up 2 grams and boiling for ten minutes with $50 \mathrm{cc}$. of $\frac{1}{1}-$ n. hydrochloric acid, the process being thrice repeated. The residue was collected and the extract analyzed, with the following results : - 
Residue : 59.6 per cent, dried at $110^{\circ} \mathrm{C}$.

Ignition loss of same: 8.32 per cent.

Extract, in percentages of original material:-

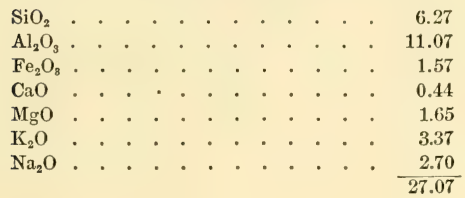

The substance is thus divided into :-

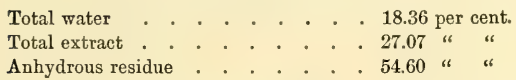

From this experiment it is seen that the substance gives up about three-fourths of its bases, and a larger proportion than this of its alkalies, when boiled with quite dilute acid.

Altogether, then, it may be concluded that we have at this station a thick semi-compact deposit of fairly pure zeolitic matter.

Loose concretions of white matter similar to this occur at Stations 4695 (2020 fathoms) and 4736 (2289 fathoms) in large slabs, and in the nuclei of manganese nodules at Station 2. It is also found in the manganese nodules of several of the "Challenger" stations. The tuff from Station 4695 is comparatively ferruginous, and has an ochreous appearance, though parts of it are just as white as that from Station 2. Both this tuff, and still more markedly that from Station 4736, contained much decomposed volcanic glass, which either remains as honey-colored palagonite or has disappeared, leaving vacuoles lined with limonite. In this respect the last named tuff resembles the white nuclei of nodules from "Challenger" Stations 285 and 297, with which substance, indeed, it appears to be identical.

As regards the origin of palagonitic tuffs such as those enumerated, it seems clear from the accompanying minerals and general associations that they arise from the decomposition of layers of volcanic ash which have fallen on a Red Clay bottom. Assuming the white matter to consist of zeolites, we have two possible mother-substances for it, viz., basic volcanic glass and felspar. These always occur together in volcanic ash, and the generation of zeolites from the one and the other under submarine decomposition has been amply demonstrated by the mineralogical examination of the "Challenger" dredgings. The zeolites have been deposited from solution, as is evidenced by their proneness to form easts in Globigerina shells, and have often the appearance of having soaked, as it were, out of the mother-substance.

Now the peculiarity of the tuff from Station 2 lies in the almost complete absence of true palagonite or the remains of palagonite, whence its white color and low iron-content. The layer of rock-silicates from which it was derived would seem therefore to have consisted mainly of acid minerals with an insignificant proportion of ferro-magnesian ores ; and since there is no evidence of the presence of rhyolitic glass in the deposit or neighborhood, the minerals were, doubtless, chiefly felspathic. That is, the original voleanic ash must have been more or less sorted before reaching the bottom, presumably by reason of the lower specific gravity of felspar. We may suppose either that a richly ferruginous layer of ash sank home underneath a felspathic layer, or, what is more probable, that the felspathic fragments, whilst sinking, were carried sideways by an oceanic current, and 
eventually came to rest as a layer of felspar on a Red Clay bottom. That the ash remained suspended for some time in the sea before settling on the bottom is clear from the fact that it carried down with it some shells of pelagic Foraminifera, which are now represented by the easts above described.

Secondary products as these zeolitic masses are, they are themselves destined to pass into some more stable form of deposit. Their rarity in such bulk as at Station 2, their porous consistency, and their sporadic occurrence preserved, like flies in amber, in manganese nodules, testify to their decadent nature. Such a tuff as those here dealt with doubtless formed, at one time, an extensive and continuous sheet, which was presently broken up by movements of the earth's crust. As we now find it, it is well on its way, under the chemical attack of sea-water and the boring operations of worms, to being merged in the surrounding Red Clay.

\section{B. RED CLAY from Station 4719, 2285 fathoms.}

As pointed out in the concluding remarks, this deposit is abnormal in so far as it contains no calcium carbonate, while at the adjacent stations, where the depth is only 100 fathoms less, the deposits contain over 50 per cent of calcium carbonate.

The elementary particles of this deposit are comparatively large, translucent, gelatinous flakes, which readily sink when suspended in water, whereas the fine opaque particles of an argillaceous Red Clay of the Atlantic or North Pacific type, or ordinary terrestrial clay, remain suspended for a long time. Under the microscope the gelatinous and semitransparent character of the deposit is still further brought out; the coloring-matter, so far as it does not consist of occasional specks of manganese, seems to be dissolved rather than disseminated in the substance, and varies in intensity from place to place, whence the mottled look of the deposit. When nearly, but not quite, dried, the substance is intensely slippery and unctuous to the touch, far more so than ordinary Red Clay.

The deposit yields very readily to the attack of warm or even, on prolonged standing, of cold dilute acid, an almost colorless flocculent residue being left behind.

A chemical analysis of the deposit was made, and an extraction test was carried out by boiling up one gram three times with $50 \mathrm{cc}$. of $\frac{1}{1}-\mathrm{n}$. hydrochloric acid and analyzing the filtrate. The extraction-residue consisted mainly of hydrated silica, with a little alumina, iron, and manganese.

The analytical figures for the deposit itself and for the extract, calculated to substance dried at $110^{\circ} \mathrm{C}$., are as follows :-

\begin{tabular}{|c|r|r|}
\hline & Analygis. & Extract. \\
\hline & & \\
\hline Ignition loss & 9.91 & 8.75 \\
$\mathrm{SiO}_{2}$ & 45.31 & 4.72 \\
$\mathrm{Al}_{2} \mathrm{O}_{8}$ & 6.39 & 22.80 \\
$\mathrm{Fe}_{2} \mathrm{O}_{3}$ & 23.72 & 4.13 \\
$\mathrm{MnO}_{2}$ & 4.93 & 0.89 \\
$\mathrm{CaO}$ & 1.11 & 4.86 \\
$\mathrm{MgO}$ & 5.81 & 1.40 \\
$\mathrm{~K}_{2} \mathrm{O}$ & 1.61 & 0.91 \\
$\mathrm{Na}_{3} \mathrm{O}$ & 0.95 & \\
\hline & & \\
& & \\
& & \\
\hline
\end{tabular}


It is seen that both the absolute percentage of ferric oxide and its ratio to alumina are remarkably high, as also is the magnesia-content. The alkalies, perhaps, are rather higher than one would expect in the truly argillaceous portion of a northern Red Clay. The extraction test shows how loosely the bases are combined with silica; an argillaceous Red Clay would retain its bases, and especially its iron, more tenaciously under acid attack.

The appearance of the deposit suggests comminuted palagonite rather than true clay. In chemical composition it differs slightly from palagonite by excess of magnesia and defect of alkalies. If we take it, then, that the deposit is not argillaceous, we have two alternative views of its nature, between which it is difficult to decide.

On the one hand, the deposit may be palagonite in the process of breaking down to clay, that is in a post-palagonitic stage. The complete disappearance of minerals, and the structureless condition of the deposit favor this view.

On the other hand, it follows from the analysis that the deposit is less like palagonite than the basic volcanic glass from which palagonite is derived (cf. Murray and Renard, Challenger Report on Deep-Sea Deposits, page 307); in fact, it markedly resembles this glass plus water. Doubtless the first stage of decomposition of basic glass is simply hydration without exchange of bases with the surrounding sea-water. Thus the deposit may be a not fully developed palagonite. If this were the case, we should expect to find remnants of original glass and palagonitic pseudomorphs of the glass fragments. The absence of these may perhaps be accounted for by a fine state of subdivision of the mother-substance, and further by trituration of the deposit through volcanic movements.

In general, the Red Clays from this region of the Pacific seem to be of a different character from North Pacifie and North Atlantic Red Clays, apart from the circumstance that they are richer in manganese and therefore of a darker color. It was observed, for instance, that the Red Clay from Station 4701 (2265 fathoms), and the Red Clays which are disseminated in Globigerina Oozes, Station 4705 (2031 fathoins) and Station 4707 (2120 fathoms), behave towards dilute acid like the Red Clay from Station 4719 under diseussion. It is almost possible to differentiate North and South Pacific specimens by boiling a small quantity with dilute hydrochloric acid in a test-tube. The South Pacific variety leaves a white residue in large flakes; the North Pacific variety a light grayish- or pinkish-brown residue in finer flakes; the residue from North Atlantic Red Clay, again, has a decided reddish-brown color. In chemical composition, the most striking point of difference lies in the higher contents of magnesia and alkalies in the South Pacific variety. The great predominance of iron at Station 4719 is probably a local peculiarity.

That Red Clay should vary so considerably in character need cause no surprise when we remember what very different mother-substances it is derived from. It is a product mainly of acid volcanic glasses (pumice) in the North Pacific, and of basic volcanic glasses in the South Pacific. The former materials decompose slowly, so that much finely-divided undecomposed pumice is found intimately mixed with the Red Clay; the latter contain more manganese and pass, in decomposing, through a palagonitic stage. These differences explain, at least to some extent, the differences in the respective Red Clays. 


\section{.}




\section{EXPLANATION OF THE PLATES.}

(All the figures are natural size.) 
Plate 1.

Fic. 1. Typical manganese nodule from Station 4658 , November 14 , 1904, lat. $8^{\circ} 29.5^{\prime} \mathrm{S}$, long. $85^{\circ} 35.6^{\prime} \mathrm{W}$., depth, 2370 fathoms. All the nodules dredged from this station may be referred to this type. The photograph shows well the symmetrical shape round an axis, and the two surfaces, one smooth, the other roughly mammillated.

FiG. 2. Section of another nodule from Station 4658. The apex is occupied by a wellpreserved ear-bone. The structure in alternate layers is well displayed, showing how the internal layers espouse the contours of the dome-shaped smooth surface. 

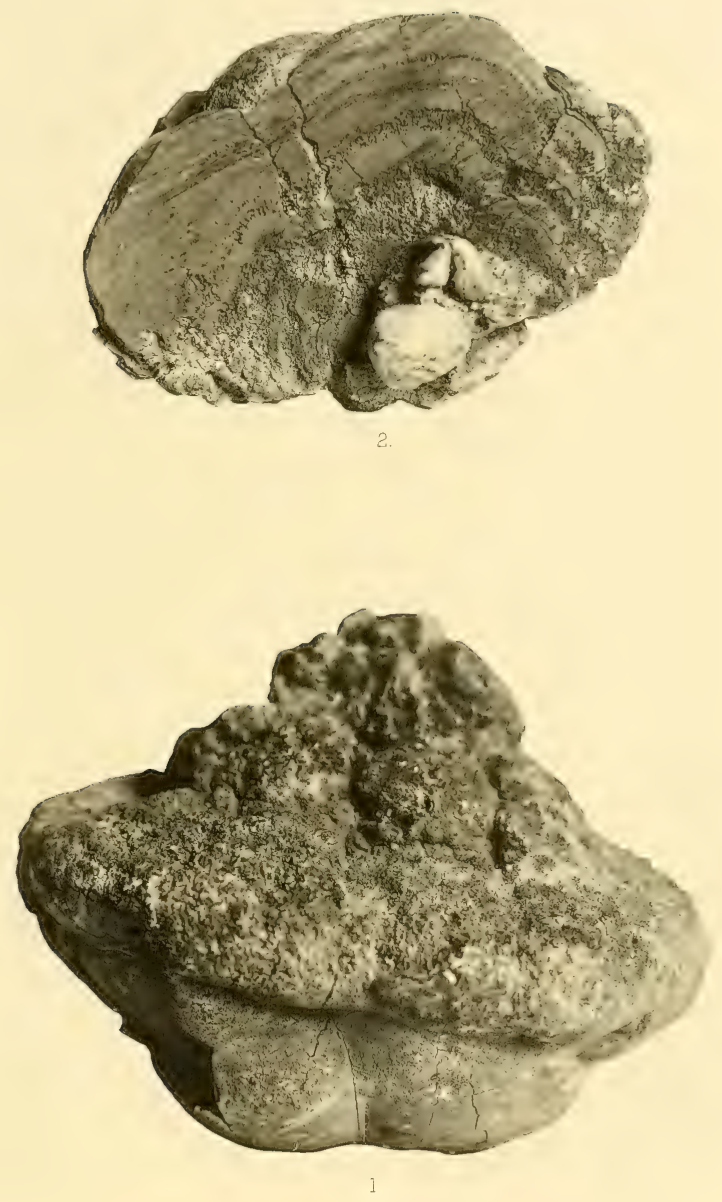

Plate 2. 


\section{Plate 2.}

Fra. 3. Typical nodule from Station 4662, November 16, 1904, lat. $11^{\circ} 13.8^{\prime} \mathrm{S}$, long. $89^{\circ} 35^{\prime} \mathrm{W}$., depth, 2439 fathoms. The nodules from this station are, contrary to what obtains at most stations, variable in shape and structure. This photograph represents a typical nodule of the second category as indicated in the text. The one surface is finely mammillated and resembles shagreen, while the other surface is smooth, with broad, flat protuberances.

F1G. 4. Typical nodule from Station 4711, December 31, 1904, lat. $7^{\circ} 47.5^{\prime} \mathrm{S}$, long. $94^{\circ} 5.5^{\prime} \mathrm{W}$., depth, 2240 fathoms. This large nodule shows the high degree of mammillated structure, the large mammillæ being covered by smaller mammillæ. All the nodules dredged at this station show these characters. 

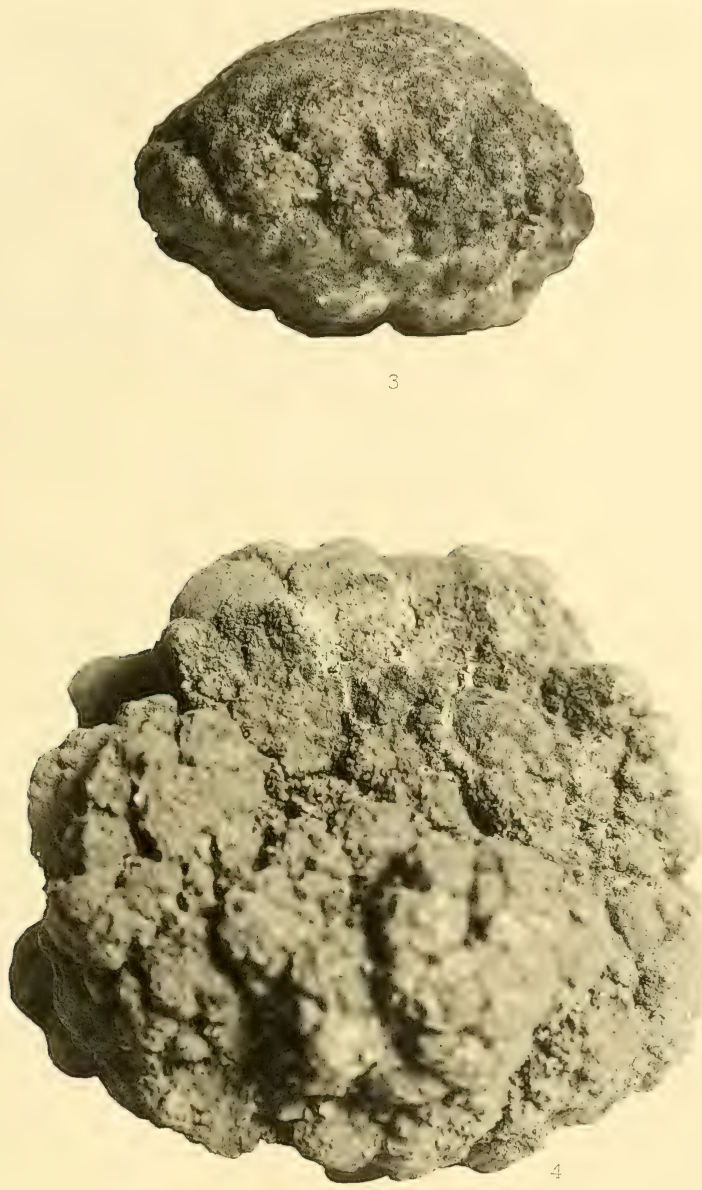

Plate 3. 


\section{Plate 3.}

FIG. 5. Skeleton of siliceous Sponge, impregnated with the oxides of manganese and iron, from Station 4721, January 15, 1905, lat. $8^{\circ} 7.5^{\prime} \mathrm{S}$., long. $104^{\circ} 10.5^{\prime} \mathrm{W}$., depth, 2084 fathoms. The siliceous spicules are preserved, so that there is no replacement, but deposition. A similar case was observed among the material dredged at Station 4656 .

Fig. 6. Consolidated Globigerina Ooze from Station 4693, December 14, 1904, lat. $26^{\circ} 30.1^{\prime}$ S., long. $105^{\circ} 45.2^{\prime} \mathrm{W}$., depth, 1142 fathoms. This slaggy-looking concretion is mainly made up of the shells of pelagic Foraminifera cemented together by, and subsequently impregnated with, the oxides of manganese and iron, which are irregularly distributed through the consolidated ooze, and do not form concentric layers.

Fig. 7. Lump of white ashy material, broken off some larger mass, and being enveloped by a coating of manganese-iron oxides, from Station 2, August 27, 1899, lat. $28^{\circ} 23^{\prime} \mathrm{N}$., long. $126^{\circ} 57^{\prime}$ W., depth, 2368 fathoms. A worm burrow traverses the white core. This may be taken as a term of transition between cakes of pure white ashy substance and manganese nodules. The white internal portions of these nodules are formed of palagonitic tuff, of which Dr. Caspari gives an analysis in the appendix.

Fig. 8. Section through a typical nodule from Station 2. The white portions are of the same nature as the white core in Fig. 7. The manganese-iron oxides may be seen impregnating the white portion, not deposited in alterante layers round a nucleus; two worm burrows are well shown. 

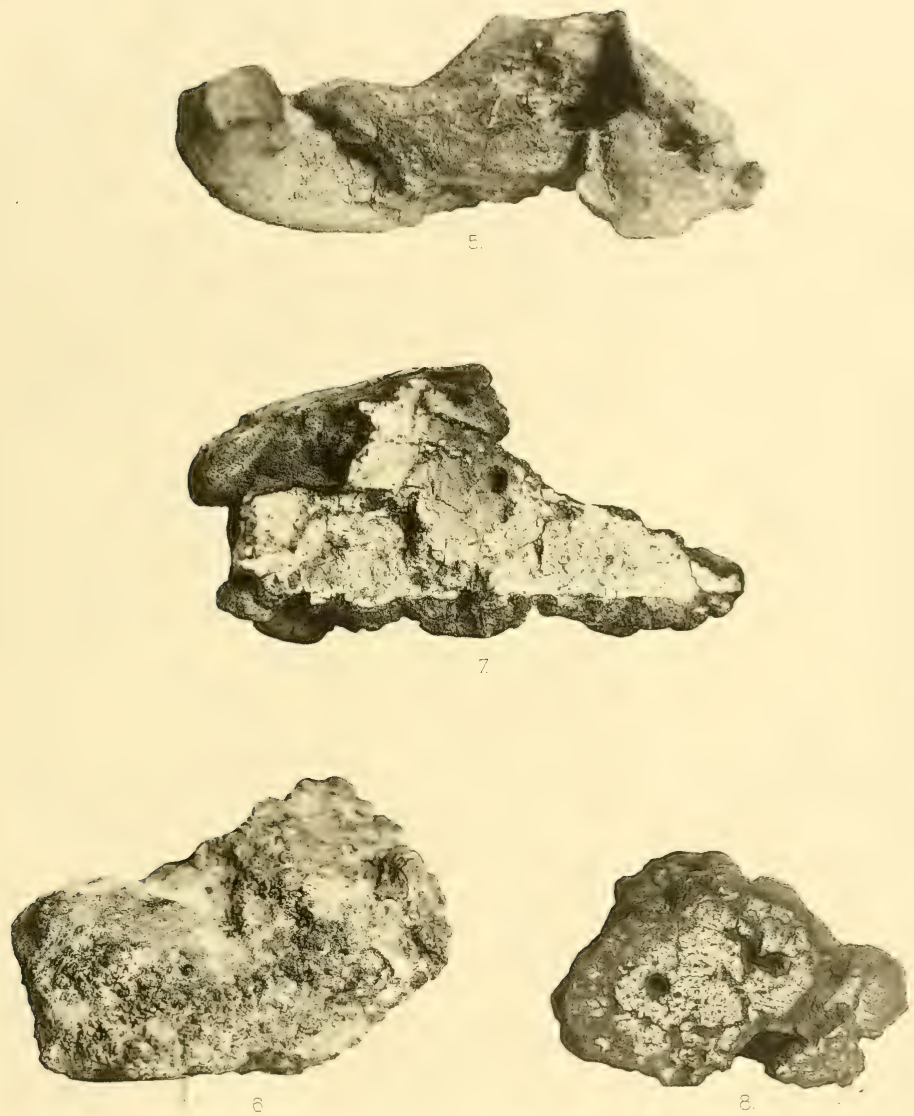


\section{.}


Plate 4. 


\section{Plate 4.}

Fig. 9. Typical nodule from Station 13 , September 5, 1899, lat. $9^{\circ} 57^{\prime}$ N., long. $137{ }^{\circ} 47^{\prime}$ WV., depth, 2630 fathoms. Nodules of this size are very abundant at this station. The shape and surface characters are also highly characteristic, so that the nodules all look exactly alike. Note the resemblance to the nodule from Station 4711 shown in Pl. 2, Fig. 4.

Fig. 10. Spherical nodule from Station 173, November 4, 1899, lat. $18^{\circ} 55^{\prime} \mathrm{S}$, long. $146^{\circ} 32^{\prime}$ W., depth, 2440 fathoms, where the spherical shape is the most cornmonly met with. This photograph is given to show the remarkable surface characters. The numerous minute, closely-set mammillæ, giving the surface its coarse shagreen-like appearance, are characteristic of the nodules dredged at this point, and are to be found on all of them, whatever their shape and size may be.

FIG. 12. Section through a flat, slab-like nodule from Station 173. This figure shows, not very distinctly, the central core of palagonite, of one of the flat, slab-like nodules. The shape of the nodule corresponds to that of the nucleus.

Fra. 13. Section of nodule from Station 173. A nuclens of palagonitic substance as shown here is present in all the nodules. The photograph also shows white specks of palagonitic substance distributed throughout the thick layer of manganeseiron oxides. These specks may he seen specially well on the fractured portion, friction having more or less obliterated them on the cut surface. The dense compact nature of the layer of oxides is well displayed.

FIG. 14. Section through a small nodule from Station 173. This figure shows the relatively very large nucleus of the small nodule, sliced and mounted on a slide. 

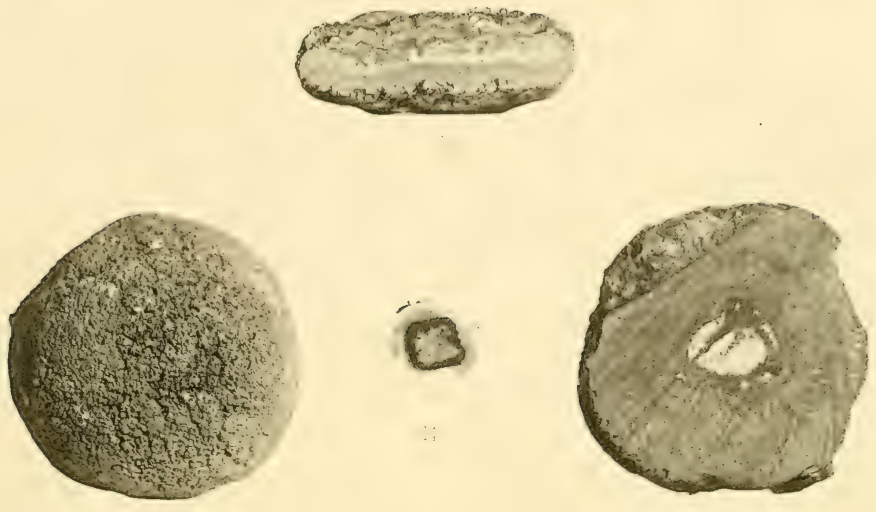

ic

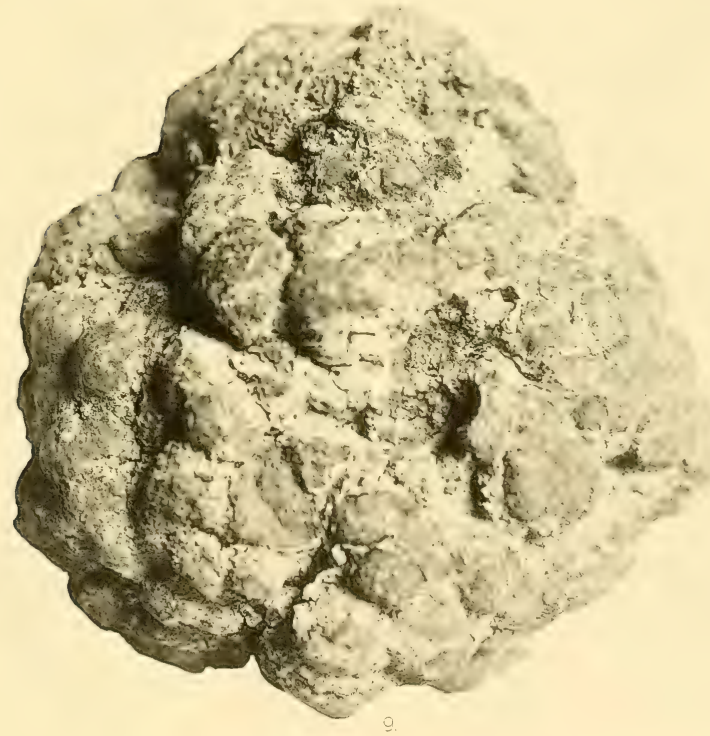



Plate 5. 


\section{Plate 5.}

Fig. 11. A large flat, slab-like nodule from Station 173. The surface characters are similar to those exhibited on the spherical specimen shown in Pl. 4, Fig. 10. 


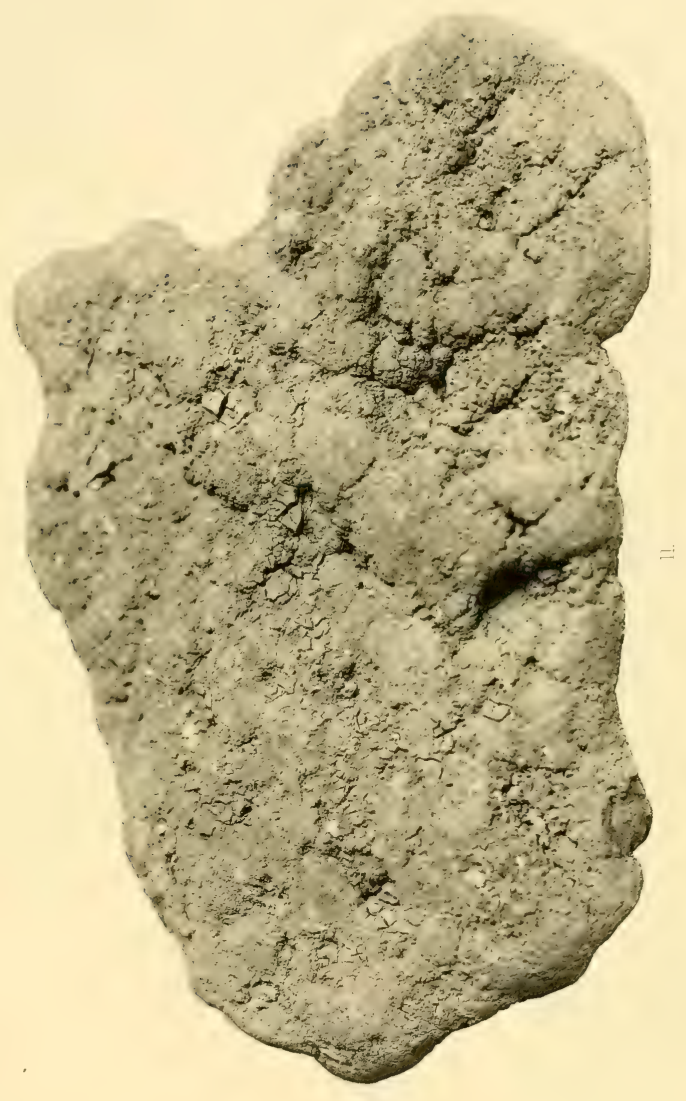



Map I. 
MAP I.

The Depths of the Pacific Ocean compiled from the latest sources, 1908. 

MAP II. 
MAP II.

Distribution of Marine Deposits in the Pacific Ocean. 


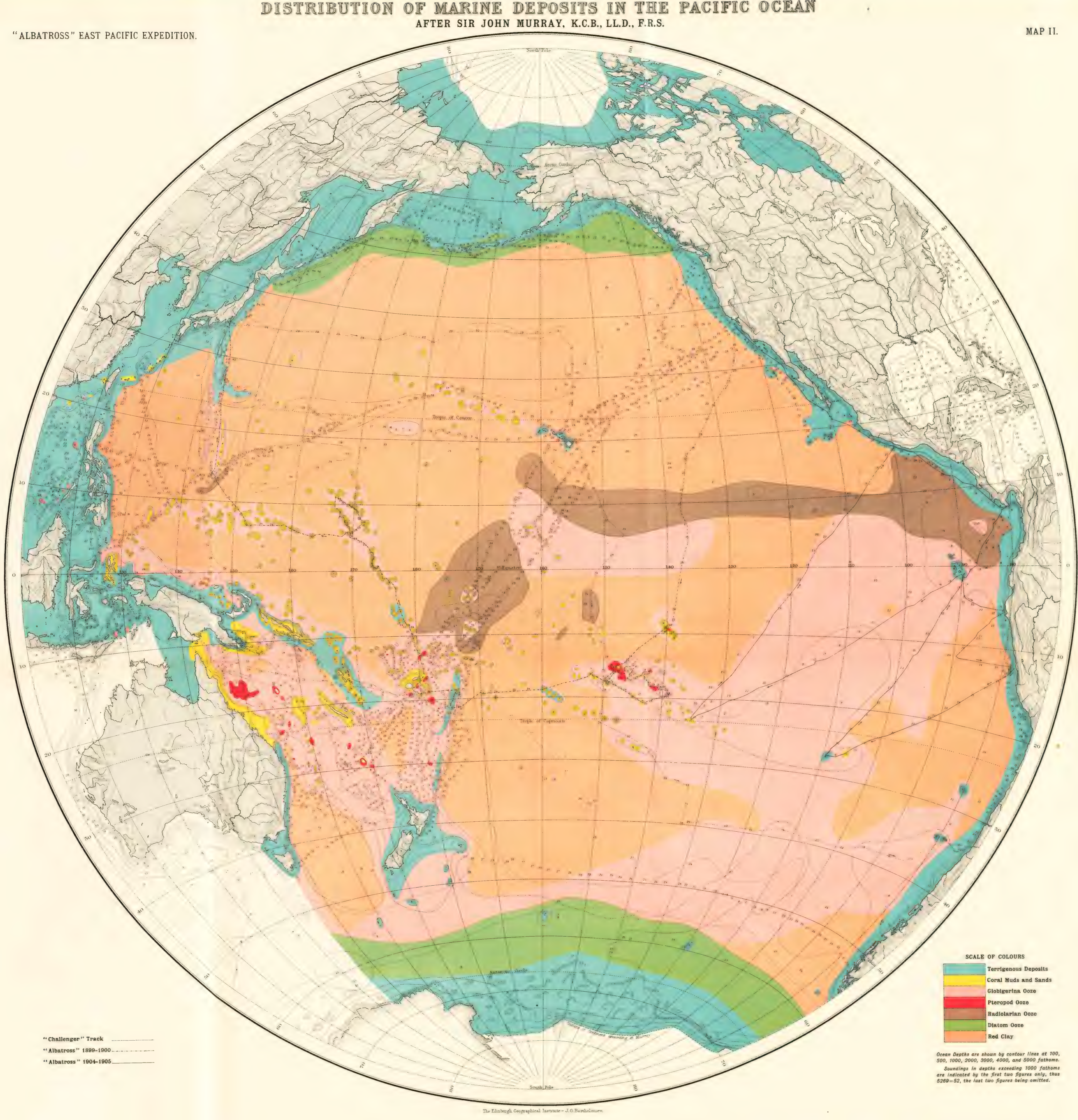



MAP III. 
MAP III.

Percentage of Calcium Carbonate in the Deposits of the Pacific Ocean. 
PERCENTAGE OF CALCIUM CARBONATE IN TEIE DEPOSITS OF TRE PACIFIC OCEAN

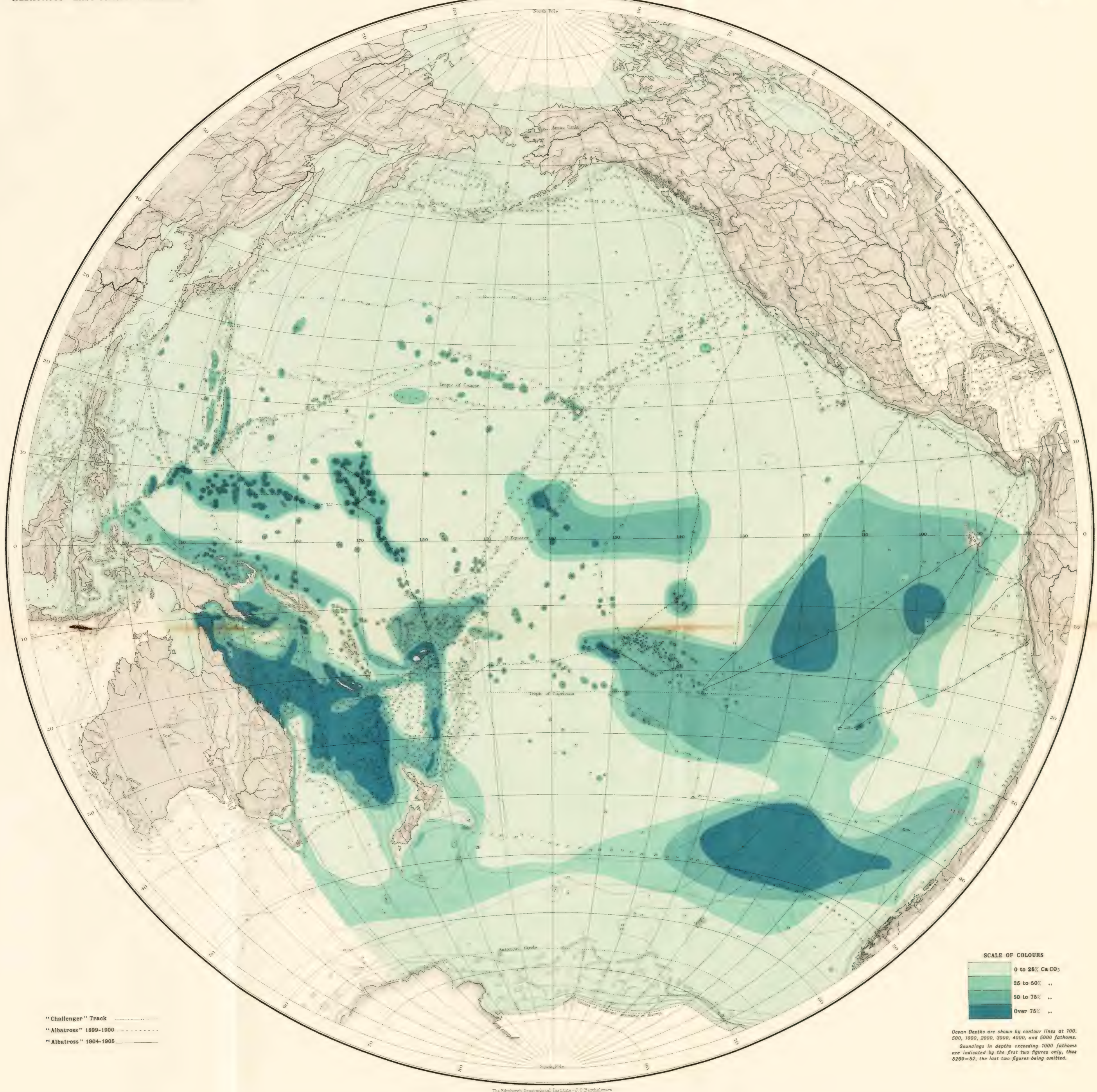





\section{EASTERN TROPICAL PACIFIC.}

The following P'ublications of the Mluseum contain Teports on the Dredging Operations in charge of Alexander Ayassiz, of the U. S. Fish Commission Steamer "Albatross," during 1904 and 1905, Licut. Commander L. M. Garrett, U.S. N., commanding.

I. A. Agassiz. Three Letters to the Hon. George M. Bowers. Bull. M. C. Z., Vol. XLVI. No. 4. April, 1905. $22 \mathrm{pp}$.

II. Hanriet Richandoson. Description of a New Genus of Isopods, Typical of a Peculiar Family. Bull. M. C. Z., Vol. XLVI. No. 6. July, 1905. 4 pp. 1 Plate.

III. C. $\Lambda$. Korord. Craspedotella, a New Genus of the Cystoflagellata, an Example of Convergence. Bull. M. C. Z., Vol. XLVI. No. 9. September, 1905. 6 pp. 1 Plate.

IV. W. E. Ritrer. Octacnemus. Bull. MI. C. Z., Vol. XLVI. No. 13. January, 1906. 22 pp. 3 Plates.

V. A. Agassiz. General Report of the Expedition. Mem, M. C. Z., Vol. XxXIII. January, 1906. 14, 75 pp. 96 Plates.

VI. T. W: Vaughan. Madreporaria. Bull. M. C. Z., Vol. L. No. 3. August, 1906. 14 pp. 10 Plates.

VII. C. R. Eistman. Sharks' Teeth. and Cetacean Bones. Bull. M. C. Z., Vol. L. No. 4. November, 1906. 26 pp. 4 Plates.

VIII. S. F. Clakke. The Hydroids. Mem. M. C. Z., Vol. XXXV. No. 1. February, 1907. 20 pp. 15 Plates.

IX. C. A. KofoID. New Species of Dinoflagellates. Bull. M. C. Z., Vol. L. No. 6. February, 1907. 48 pp. 17 Plates, 1 Chart.

X. Mary J. Rathbun. The Brachyura. Mem. M. C. Z., Vol. XXXV. No. 2. August, 1907. 56 pp. 9 Plates.

XI. F. E. Scholze. Die Xenophyophoren. Bull. M. C. Z, Vol. LI. No. 6. November, 1907. 22 pp. 1 Plate.

XII. S. Garman. The Reptiles of Easter Island. Bull. M. C. Z, Vol. LII. No. 1. June, 1908. 14 pp. 1 Plate.

XIII. E. C. Stanks. The Characters of Atelaxia, a New Suborder of Fishes. Bull. M. C. Z., Vol. LII. No. 2. July, 1908 . 8 pp. 5 Plates.

XIV. W. H. Dall. The Mollusca and the Brachiopoda. Bull. M. C. Z., Vol. XLIII. No. 6. October, 1908. 285 pp. . 22 Plates.

XV. J. Thiele. Ueber die Anatomie und systematische Stellung von Bathysciadium Lepetella, und Addisonia. Büll. M. C. Z., Vol. LII. No. 5. October, 1908. 12 pp. 2 Plates.

XVI. H. B. Brgelow. The Medusæ. Mem. M. C. Z., Vol. XXXVII. February, 1909. 243 pp. 48 Plates.

XVII. John Mrorray and G. V. Lee. The Depth and Marine Deposits of the Pacific. Mem. M. C. Z., Vol. XXXViII. No. 1. May, 1908. 172 pp. 5 Plates, 3 Maps. 


\section{PUBLICATIONS}

OF THE

\section{IUSEUY OF COMPARATIVE ZOÖLOGY \\ AT HARTARD COLLEGE.}

There hare been published of the ButLerrs Tols. I. to LI.; of the Mestones. Fols. I. to XX1Y.. and also Vols. XXVIII.. XXIX, XXXI. to XXXIII., and XXXiri.

Tols. LII. and LIII. of the BuLletis, and Tols. XXT., XXTI, XXVI., XXX., XXXIT, XXXT., XXXTI, and XXXVIII. of the Mexoras, are now in course of publicativa.

A price list of the publications of the Museum will be sent on application to the Librarian of the Museum of Comparatice Zoülogy, Cambridge, Mass. 






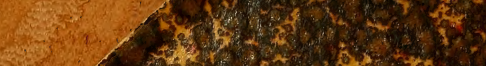

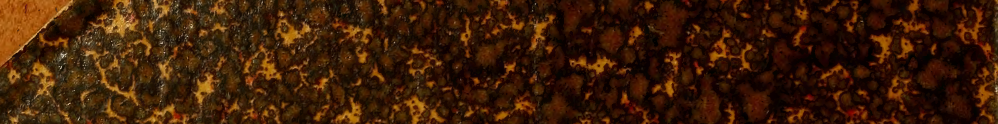

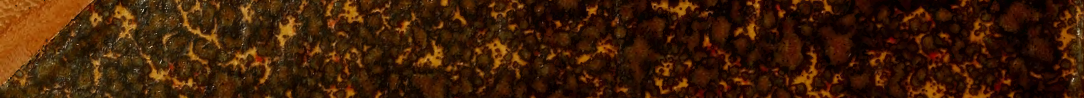

4.

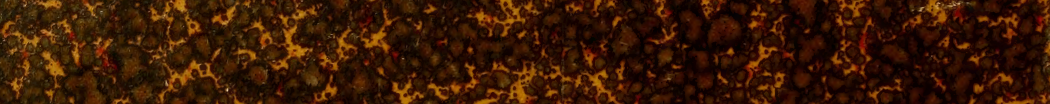
H 2. (6. H.

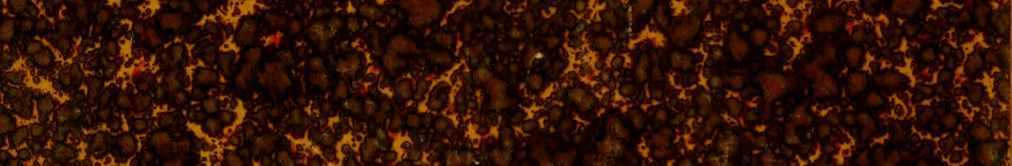
(1)

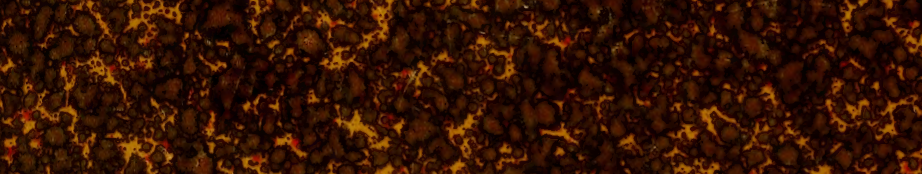
(2) Noth

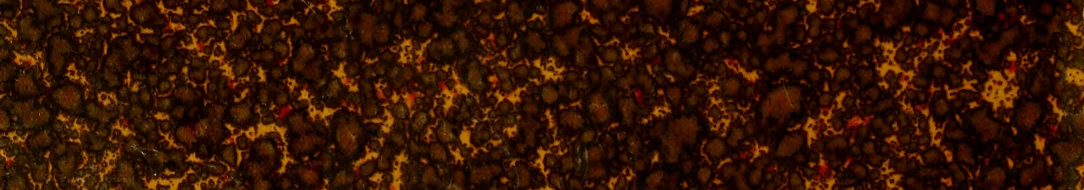
1.

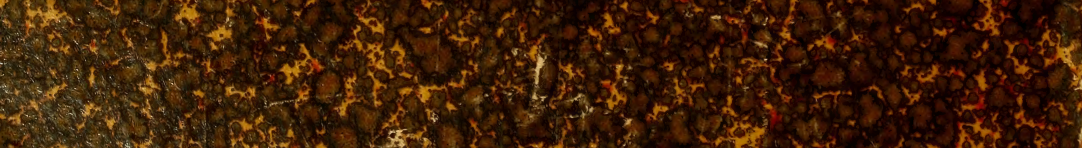
W

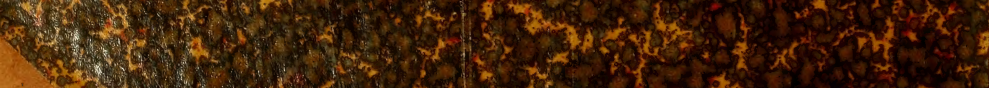

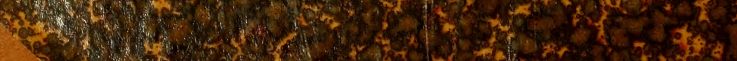

